RENATA GOMES DA SILVA

\title{
RELAÇÕES ENTRE OS ENTES FEDERADOS NAS POLÍTICAS PÚBLICAS DE HABITAÇÃO: UMA ANÁLISE DO SISTEMA NACIONAL DE HABITAÇÃO DE INTERESSE SOCIAL
}

\author{
Dissertação de Mestrado \\ Orientador: Professor Titular Fernando Dias Menezes de Almeida
}

Faculdade de Direito da Universidade de São Paulo

São Paulo 


\title{
RELAÇÕES ENTRE OS ENTES FEDERADOS NAS POLÍTICAS PÚBLICAS DE HABITAÇÃO: UMA ANÁLISE DO SISTEMA NACIONAL DE HABITAÇÃO DE INTERESSE SOCIAL
}

\author{
Dissertação apresentada ao Programa de Pós- \\ Graduação da Faculdade de Direito da \\ Universidade de São Paulo como requisito parcial \\ para a obtenção do título de Mestre junto ao \\ Departamento de Direito do Estado.
}

Orientador: Professor Titular Fernando Dias Menezes de Almeida

Faculdade de Direito da Universidade de São Paulo

São Paulo

2014 
“... Do povo oprimido nas filas, nas vilas, favelas Da força da grana que ergue e destrói coisas belas..."

(Caetano Veloso)

A todos que lutam. 


\section{Agradecimentos}

Gostaria de agradecer a todos que fizeram parte desse trabalho: pais, professores, amigos, colegas, funcionários, desconhecidos.

A todos que ajudaram com suas reflexões, críticas, apoio ou carinho.

A todos que tentam tornar o mundo mais justo, menos desigual.

A todos que dão inspiração e suor a cada batalha diária.

Gostaria de agradecer à Faculdade de Direito que me propiciou tantos encontros, indignações e pensamentos.

Ao meu orientador que me ofereceu a oportunidade de estudar o tema que mais me interessava com toda a liberdade de reflexão.

Aos meus amigos do Núcleo de Direito à Cidade, do DJ XI de Agosto, da Casa do Estudante, das arcadas, da Secretaria de Gestão Pública, da vida.

À minha família. 


\section{Sumário}

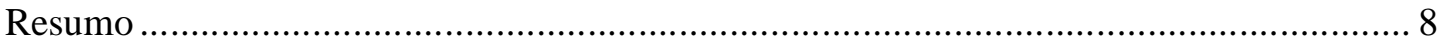

Capítulo 1: FEDERALISMO E POLÍTICAS PÚBLICAS ….......................................... 9

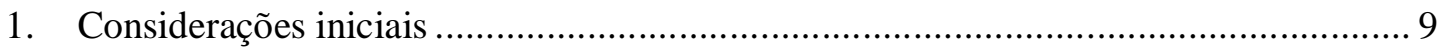

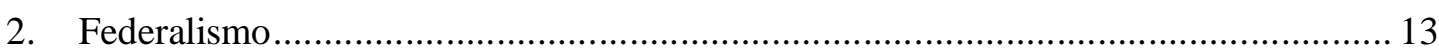

3. Breve histórico do Federalismo no Brasil .................................................................. 18

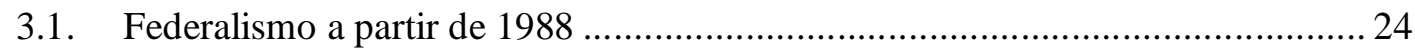

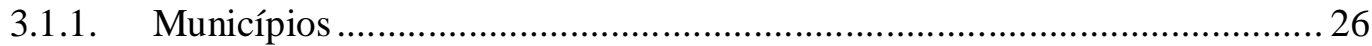

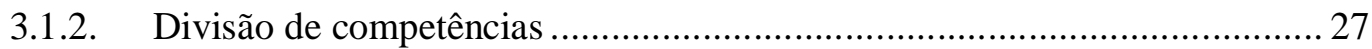

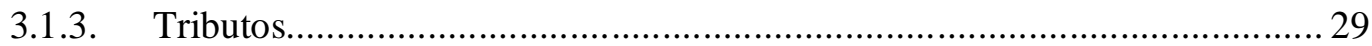

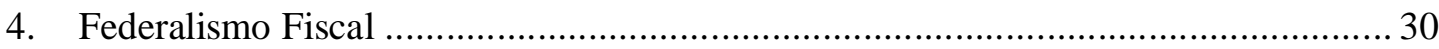

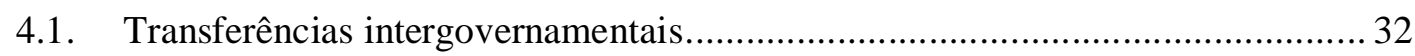

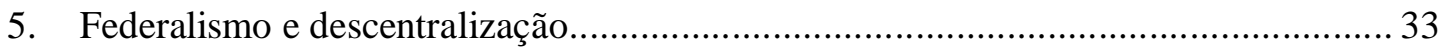

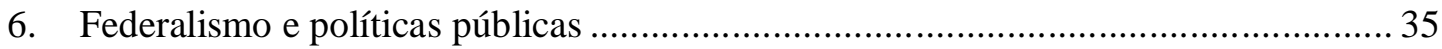

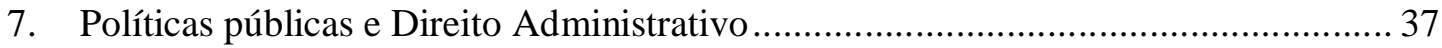

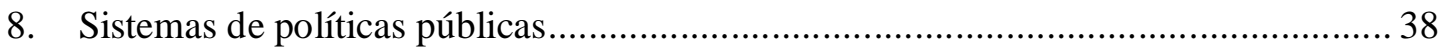

Capítulo 2: POLÍTICAS PÚBLICAS DE HABITAÇÃO NO BRASIL ............................ 41

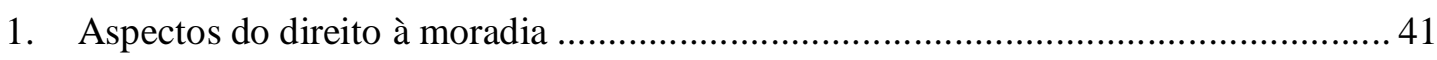

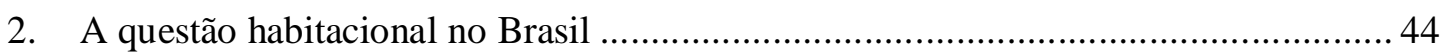

3. Breve histórico da política habitacional no Brasil .............................................. 51

3.1. Institutos de Aposentadoria e Pensão ......................................................... 52

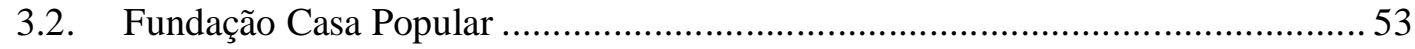

3.3. Banco Nacional da Habitação ........................................................................... 54

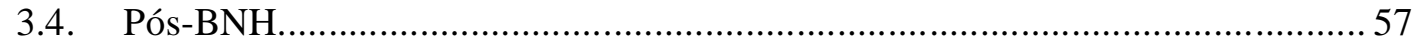

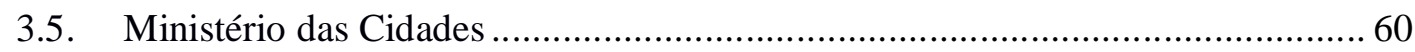

Capítulo 3: SISTEMA NACIONAL DE HABITAÇÃO DE INTERESSE SOCIAL ......... 62

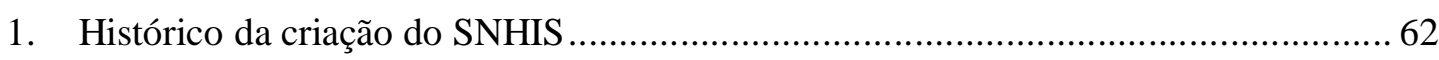

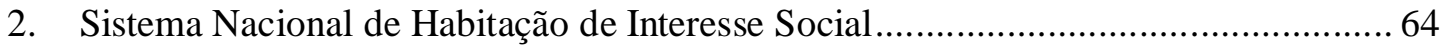

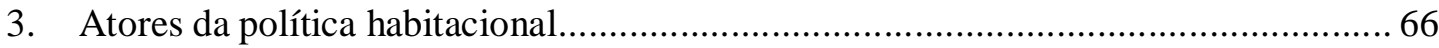

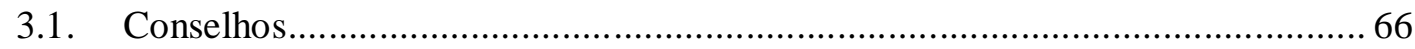

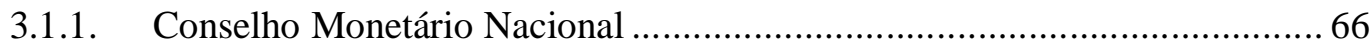

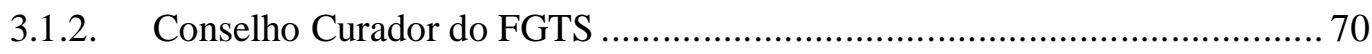

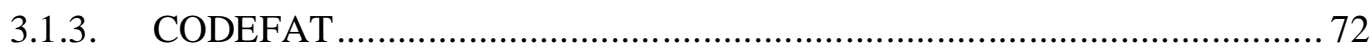


3.1.4. Conselho Curador do Fundo de Desenvolvimento Social.......................... 72

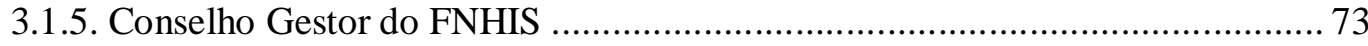

3.1.6. Conselho das Cidades ............................................................................... 73

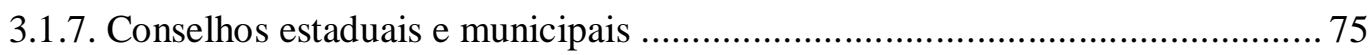

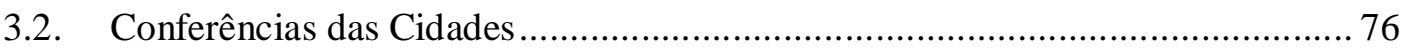

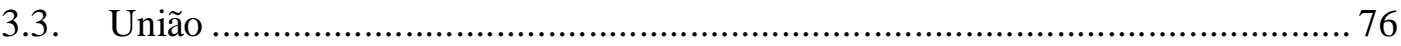

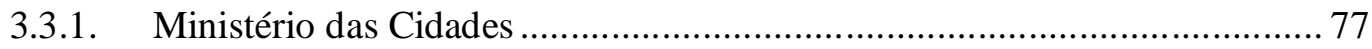

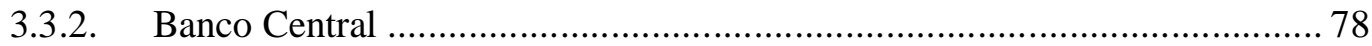

3.3.3. Ministérios da Fazenda, do Planejamento e Casa Civil .............................. 79

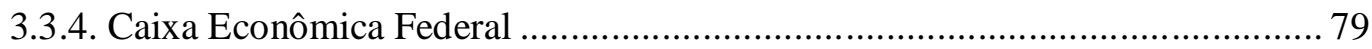

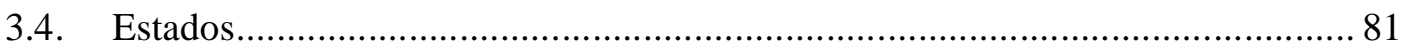

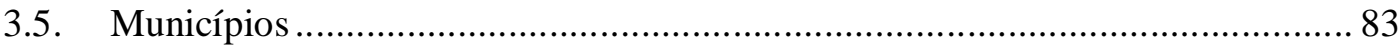

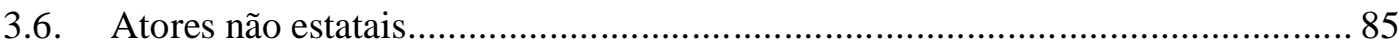

3.6.1. Empresas da construção civil................................................................... 86

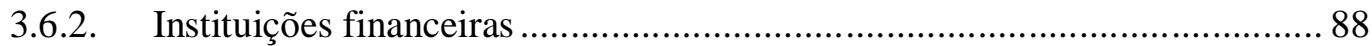

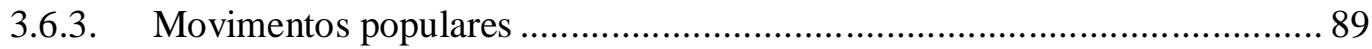

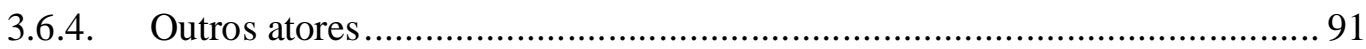

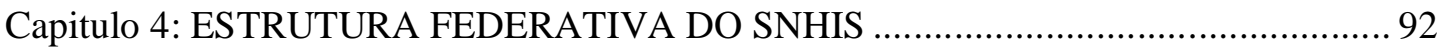

1. Sistema Nacional de Habitação de Interesse Social ..................................................... 92

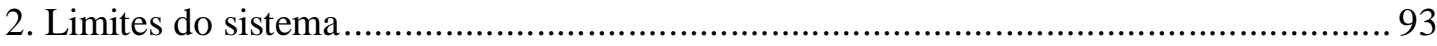

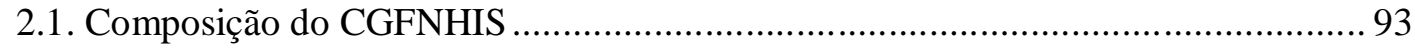

2.2. Diretrizes e destinação dos recursos .............................................................. 94

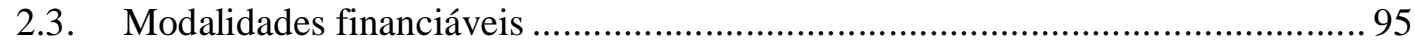

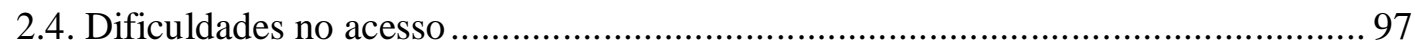

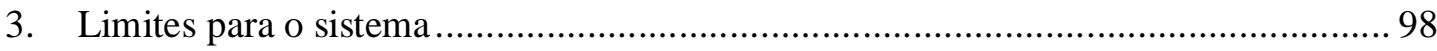

3.1. Capacidade administrativa dos Municípios ............................................. 98

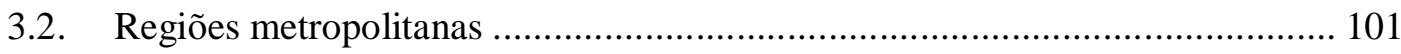

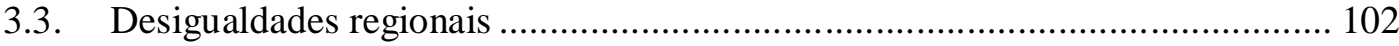

3.4. Políticas urbanas, habitacionais e outras políticas públicas ................................ 104

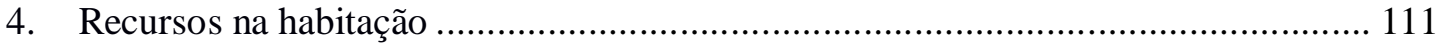

4.1. Destaque ao financiamento habitacional ............................................................. 114

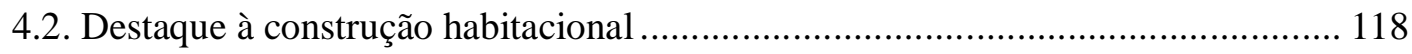

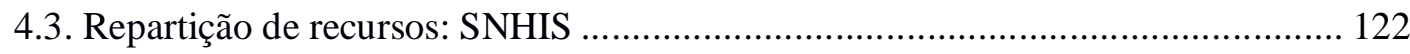




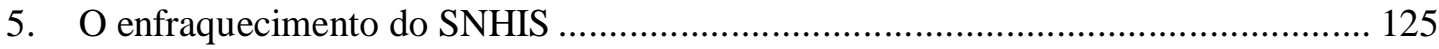

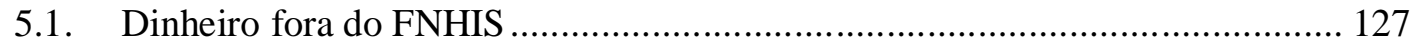

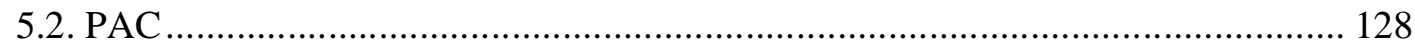

5.3. Programa Minha Casa Minha Vida................................................................ 129

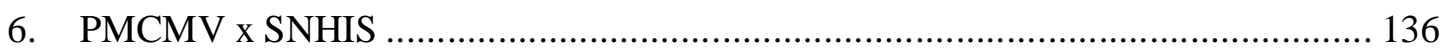

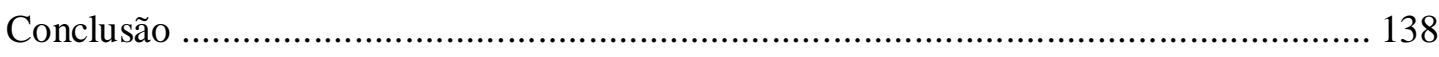

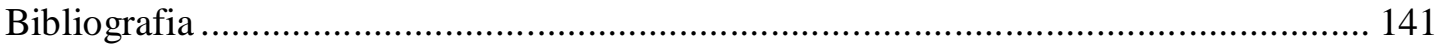




\section{Resumo}

O trabalho aborda como se dão as relações entre os entes federados nas políticas públicas de habitação, realizando um histórico do federalismo no Brasil, das políticas habitacionais e descrevendo o papel de cada ator, analisando de maneira específica o Sistema Nacional de Habitação de Interesse Social. Conclui-se que o modelo do sistema, já centralizado, foi subjugado pelo Programa Minha Casa Minha Vida e pelo Programa de Aceleração do Crescimento, impedindo precocemente o desenvolvimento de uma estrutura que declarava buscar a coordenação das políticas e o planejamento com participação popular, substituída por outra que estimula a renúncia fiscal, a alteração pontual da legislação urbanística e a doação de imóveis pelos entes federados. O modelo de política habitacional federal atual prioriza o financiamento e a construção, desestimulando o desenvolvimento de políticas

urbanas e políticas habitacionais alternativas locais, prejudicando o acesso universal à moradia e à cidade.

Palavras-chave: moradia, políticas públicas, federalismo. 


\section{Capítulo 1: FEDERALISMO E POLÍTICAS PÚBLICAS}

\section{Considerações iniciais}

Por vezes, as definições de federalismo escondem uma multiplicidade de situações que apenas com muito esforço ou elasticidade conceitual podem ser inseridas na mesma categoria. De maneira mais estrita, apesar de características comuns, é possível afirmar que existem tantos federalismos quantas federações, já que, apesar de alguma coincidência na estrutura geral, em cada país o federalismo tem origens, se desenvolve e se concretiza cotidianamente de maneiras diversas.

Debates já se travaram sobre categorias de federações, agrupando-as de acordo com a origem, o funcionamento, entre outros, mas, na verdade, as especificidades tornam essas classificações generalizantes em demasia.

De modo geral, o funcionamento de uma federação ultrapassa as regras formais impostas constitucional e legalmente, sendo influenciado por uma série de outros fatores, conforme observa Paul Pierson (1995, p. 473): As instituições federais operam em conjunto com outras importantes variáveis: a estrutura do sistema partidário, a natureza de uma política econômica particular, a distribuição geográfica de grupos minoritários. ${ }^{1}$

Desse modo, um estudo que se limite a observar as regras formais e declaradas pode trazer um viés limitado da realidade de uma federação. William Riker (1969, p. 146), em uma resenha sobre trabalhos acerca do federalismo, atenua a importância do seu estudo de maneira exclusivamente teórica: No estudo de governos federais, portanto, é sempre apropriado ir além da ficção para estudar as forças reais em um sistema político. ${ }^{2}$

A importância do conhecimento teórico acerca do federalismo brasileiro não exclui a necessidade de entendimento das relações mais prosaicas do relacionamento entre os entes federados. A interferência da política partidária, as relações da União diretamente com os Municípios, o papel dos Estados, a busca por votos, a dinâmica das transferências

\footnotetext{
${ }^{1}$ Tradução livre de: "Federal institutions operate in conjunction with other important variables: the structure of party systems, the nature of a particular political economy, the geographical distribution of minority groups."

${ }^{2}$ Tradução livre de: "In the study of federal governments, therefore, it is always appropriate to go behind the fiction to study the real forces in a political system."
} 
orçamentárias, as coalizões construídas, entre outros fatores, influenciam no desempenho das instituições, das relações e dos produtos e impactos de uma política pública.

Marta Arretche (2009, p. 407) considera que o desenho institucional da federação brasileira, apesar de virtualmente oferecer oportunidades de veto aos governos subnacionais sobrerrepresentados como Roraima, não apresentou esse resultado na prática das votações de emendas constitucionais que afetariam os interesses dos entes federados, já que estas foram, em sua maioria, aprovadas:

Em outros termos, o fato de que tenham sido aprovadas 21 emendas constitucionais que afetaram o status quo federativo - das 23 PECs com esse conteúdo votadas na Câmara dos Deputados - revela que não há obstáculos institucionais de grande monta para aprovar emendas constitucionais no Brasil, mesmo quando seu conteúdo expropria direitos das unidades constituintes.

A pesquisa analisa dados de votações de emendas à constituição e leis, que de alguma maneira foram consideradas pela autora como prejudiciais à autonomia dos Estados e Municípios ${ }^{3}$, como a Lei de Responsabilidade Fiscal, e observa que a aprovação dessas matérias pode ser explicada pela fidelidade dos parlamentares às lideranças partidárias. Além disso, Arretche (2009, p. 410) observa que não é previsto nenhum instrumento institucional de votação diferenciada para matérias que envolvam interesse federativo, como, por exemplo, a aprovação das assembléias estaduais, e mesmo para as alterações constitucionais são exigidos os votos de somente $60 \%$ dos membros de cada Casa do Congresso Nacional, 3/5 em duas votações:

Em suma, a combinação dos poderes jurisdicionais com as regras que regem o processo decisório em matérias de interesse federativo fornece amplas oportunidades de iniciativa e aprovação parlamentar às matérias iniciadas pelas elites do governo central. Na verdade, são as elites dos governos subnacionais que têm suas oportunidades de veto restringidas a reunir maiorias oposicionistas na Câmara dos Deputados, casa em que se inicia a maior parte das iniciativas

\footnotetext{
${ }^{3}$ Nesta pesquisa, além das propostas de emenda à Constituição, a autora levantou "todas as iniciativas legislativas de interesse federativo - envolvendo matérias relativas à distribuição de autoridade em questões de tributação, gastos e encargos -, submetidas à votação na Câmara dos Deputados, do governo Sarney (posteriormente à aprovação da CF 88) ao primeiro governo Luiz Inácio Lula da Silva: no total, 59 iniciativas legislativas que tramitaram pelo Congresso entre 1989 e 2006. [...] Essa análise permitiu classificar as 59 iniciativas de acordo com o tipo de interesse dos governos subnacionais afetado por seu conteúdo, a saber: (a) matérias que afetaram as receitas de Estados e Municípios; (b) matérias em que a legislação federal afeta a autonomia decisória dos governos subnacionais na arrecadação de seus próprios impostos; (c) matérias em que a legislação federal afeta a autonomia decisória dos governos subnacionais no exercício de suas próprias competências; (d) matérias em que a legislação federal afeta a autonomia decisória dos governos subnacionais para decidir sobre a alocação de suas próprias receitas." ARRETCHE, Marta. Continuidades e Descontinuidades da Federação Brasileira: De como 1988 facilitou 1995 In DADOS - Revista de Ciências Sociais, Rio de Janeiro, vol. 52, n. 2, 2009, pp. 377-423, p. 384.
} 
legislativas. [...] O jogo tem grandes chances de terminar se o presidente conseguir reunir uma coalizão majoritária baseada nos partidos que lhe dão sustentação no Congresso.

Como é a Constituição Federal (CF) que garante a divisão de competências, o que é essencial para o federalismo, a falta de um procedimento diverso do comum para a aprovação de emendas constitucionais, pode gerar um desequilíbrio, como critica Augusto Zimmermann (2005, p. 79-80):

É bastante discutível, no nosso caso, a existência de um verdadeiro federalismo. Não apenas em virtude do excesso de competências da União, mas também pela forma com que este poder central pode alterar, a seu bel-prazer, a Constituição Brasileira. Na realidade, os Estados-membros deste País sequer participam do processo de emenda constitucional, haja visto que o Senado jamais correspondeu verdadeiramente à sua função teórica de representar os interesses das unidades estaduais.

Dessa maneira, matérias como a Desvinculação das Receitas da União - DRU ${ }^{4}$ foram aprovadas, apesar de limitarem os recursos orçamentários das unidades subnacionais. A oportunidade de veto existente não foi suficiente para impedir a votação das matérias, mas um observador mais distante e preocupado com a comparabilidade do estudo em âmbito internacional pode não se preocupar com os resultados do desenho que se mostrem diferentes do que seria esperado teoricamente.

Mesmo após a aprovação de leis que instituem uma política pública, relacionando o papel dos entes federados, as disputas continuam se dando e influenciando no "como" essa lei será aplicada, ou não aplicada (ARRETCHE, 2001, p. 29-30):

Posteriormente a aprovação legislativa, as burocracias governamentais têm autoridade para traduzir leis em políticas efetivas, simplesmente pela definição das regras de implementação das políticas. Isso significa que um conjunto mais amplo de instituições políticas nas quais se opera a barganha federativa, o conflito de interesses entre executivo federal e executivos subnacionais. Adicionalmente, envolveriam, pelo menos, as relações com o Judiciário e as relações diretas entre os executivos dos distintos níveis de governo. Reduzir a

\footnotetext{
${ }^{4}$ Antes da DRU foram criados o Fundo Social de Emergência - FSE - e o Fundo de Estabilização Fiscal FEF, que desvincularam recursos da União com o objetivo de ampliarem a flexibilidade orçamentária, mas também possibilitaram gastos inferiores aos constitucional e legalmente estabelecidos para políticas públicas como educação e saúde: "O procedimento adotado através destas Emendas Constitucionais acarretou a utilização de verbas vinculadas (afetadas) a uma destinação para outros fins que não aqueles constitucionalmente previstos, e que, in casu, afetaram vastamente a concretização dos direitos humanos (ou, como deseja parte da doutrina, dos direitos fundamentais sociais) por falta de recursos para sua implementação, destinados a outras finalidades." SCAFF, Fernando Facury. Direitos Humanos e a Desvinculação das Receitas da União - DRU In Revista de Direito Administrativo, abr-jun/2004, n. 234 pp33-50, p. 48.
} 
análise do funcionamento das instituições federativas à arena legislativa federal implica necessariamente uma visão parcial e limitada dos recursos de poder de que dispõem os distintos níveis de governo para fazer representar seus interesses.

Outra questão relevante levantada em uma das pesquisas que ajudam a compreender as relações federativas no país, mais especificamente as transferências de recursos entre União e Estados, é a constatação de que os recursos da União tendem a ser direcionados a Estados que tem mais parlamentares na coalizão de governo, independente da posição do governador, segundo Marta Arretche e Jonathan Rodden (2004, p. 570):

Os presidentes brasileiros contam com considerável poder sobre a execução de recursos de transferências e usam estes recursos para superar o desafio de preservar sua coalizão de sustentação parlamentar. Para tanto, canalizam os recursos de que dispõem para os estados que contam com maior número de parlamentares na coalizão. Os parlamentares, por sua vez, têm fortes incentivos para integrar a coalizão de governo, pois daí deriva a credibilidade de que seus estados e municípios de origem receberão recursos adicionais.

Essas pesquisas empíricas destroem alguns argumentos baseados no senso comum, contribuindo para uma reflexão mais correta acerca das reais relações dentro do Estado federal brasileiro. Superar a mera leitura do texto legal é necessário, até para que este seja melhor esclarecido.

Desse modo, o presente estudo das relações federativas nas políticas públicas de habitação sob o viés do Direito Administrativo se dará com a observação dos diplomas legais, mas também contará com a análise de dados orçamentários, relatórios de gestão e de auditoria, desenvolvimento de programas habitacionais e por meio do estudo do funcionamento do Sistema Nacional de Habitação de Interesse Social (SNHIS).

O trabalho se divide em quatro partes: este primeiro capítulo abordará o federalismo, relacionando-o à unidade na diversidade e à democracia, mencionando a variedade de suas expressões nas federações existentes. Será realizado um breve histórico do federalismo no Brasil, dando destaque às Constituições federais. Após 1988, um breve comentário sobre o papel dos Municípios, a divisão de competências entre os entes federados e a distribuição de tributos, abordando o federalismo fiscal, a necessidade das transferências de recursos e a limitação que elas podem trazer à autonomia. Ainda cabe destacar as questões acerca dos direitos sociais em uma federação, especialmente a relação entre uniformidade e autonomia, bem como as políticas públicas no Direito Administrativo. A partir daí se inicia uma discussão sobre os sistemas de políticas 
públicas, recentemente criados para coordenar a ação dos entes federados em diversas políticas setoriais.

O segundo capítulo tratará da dificuldade de mensuração do problema habitacional, considerando um conceito amplo de direito à moradia e de direito à cidade, que inclua o acesso a serviços públicos e empregos aliado à participação popular nas decisões acerca das políticas públicas. A multiplicidade de indicadores e a falsidade de um déficit de habitações serão mencionados. Será feito um breve histórico das políticas públicas de habitação desenvolvidas pelo governo federal desde a República Velha, destacando-se as relações entre os entes federados e as continuidades nas políticas atuais.

O terceiro capítulo trará o histórico da criação do Sistema Nacional de Habitação de Interesse Social, desde sua origem numa proposta popular, passando pelas alterações que foram se dando no seu desenho durante a tramitação, culminando na descrição simplificada do seu funcionamento atual. Nesse capítulo são destacados os principais atores da política habitacional, incluindo atores externos ao SNHIS e ao Estado, destacando-se os papéis de cada um na formulação da agenda, no desenho, na implementação e na avaliação das políticas desenvolvidas.

Por fim, o último capítulo tratará do funcionamento da estrutura federativa do SNHIS, considerando os limites apresentados pelo seu desenho e os limites impostos pela realidade da federação brasileira. Serão abordados problemas da indução que o governo federal tem realizado e as prioridades da política habitacional atual: financiamento e construção de novas unidades. Serão mencionados os programas Minha Casa Minha Vida e de Aceleração do Crescimento, e o enfraquecimento do projeto de estruturação de um sistema coordenado com participação popular e planejamento para as políticas públicas de habitação. Além disso, serão apresentadas as conclusões do trabalho.

\section{Federalismo}

Esse trabalho não objetiva rediscutir o conceito de federalismo, mas utilizar a relação dos entes federados como uma perspectiva de observação para o estudo das políticas habitacionais no Brasil. No entanto, cabe observar diferentes definições e perspectivas trazidas por alguns autores.

Como afirma Daniel Elazar (1991, p. 15-16), o federalismo evoca muitas nuances, podendo ser interpretado de diversas maneiras diferentes: 
A este respeito, federalismo é como democracia ou republicanismo, termos clássicos que evocam várias nuances e provocam muitas brigas entre alunos da graduação porque eles são difíceis de definir, mas seu núcleo de significado pode ser bem estabelecido dentro de contextos apropriados apesar das muitas variações, barrando o uso incorreto. [...] Como um conceito de valor, ele não tem uma-e-para-todo-o-sempre definição no sentido cientifico usual, embora ele possa ser, e é definido operacionalmente em modos bem-aceitos. ${ }^{5}$

Ainda sobre a questão, Elazar (1991, p. 38) aponta a flexibilidade do federalismo, que dificulta uma abordagem teórica:

A grande força do federalismo (incluindo a ideia federal e as estruturas e processos que a seguem) reside na sua flexibilidade (ou adaptabilidade), mas esta força torna difícil discutir satisfatoriamente o federalismo num nível teórico. Mesmo o argumento de que o federalismo é particularmente flexível vai contra muito da discussão convencional da matéria, que, na medida em que se concentra no entendimento jurídico de federalismo, freqüentemente enfatiza divisões rígidas de poder. Embora determinados sistemas federais possam ser inflexíveis, o princípio federal tem sido aplicado com sucesso em uma grande variedade de maneiras, sob uma enorme variedade de circunstâncias. ${ }^{6}$

Uma relevante observação que Brian Taylor (2007, p. 422-423) traz é que muitas definições incluem a necessidade da democracia ${ }^{7}$ na definição do federalismo, porque somente ela garantiria a autonomia política necessária para as unidades locais, com demarcações claras sobre os campos de atuação:

A federação é uma forma de Estado em que o poder de tomar decisões é dividido entre governos regionais e central. Muitas definições incluem a noção que esta divisão de poder é constitucionalmente garantida e então concluem que somente democracias podem ser verdadeiramente federais, porque somente em sistemas políticos democráticos é possível que essas garantias sejam significativas. Independentemente dessa disputa, a questão-chave é que as federações não

\footnotetext{
${ }^{5}$ Tradução livre de: "In that respect, federalism is like democracy or republicanism, classic terms that evoke many nuances and provoke many arguments among undergraduates because they are difficult to define but whose core meaning can be fairly well established within appropriate contexts despite many variations, barring simply incorrect usage. (...) As a value concept, it does not have a once-and-for-all-time precise definition in the usual scientific sense, although it can be and is defined operationally in well-accepted ways."

${ }^{6}$ Tradução livre de: "The great strength of federalism (including the federal Idea and the structures and processes that flow from it) lies in its flexibility (or adaptability), but that very strenght makes federalism difficult to discuss satisfactorily on a theoretical level. Even the argument that federalism is particularly flexible goes against much of the conventional discussion of the subject, which, to the extent that it focuses on a juridical understanding of federalism, often emphasizes rigid divisions of power. Although particular federal systems may be inflexible, the federal principle has been successfully applied in a great many different ways, under a wide variety of circumstances."
}

${ }^{7}$ Nesse sentido, Dallari (1990, p. 66) afirma: "Federalismo e ditadura são incompatíveis." 
apenas descentralizam responsabilidades administrativas, mas também dividem o poder de tomar decisões políticas autorizadas. ${ }^{8}$

Gilberto Bercovici (2004, p. 11-12) destaca a questão da diversidade na unidade, caracterizando o federalismo:

Em nenhuma concepção doutrinária o federalismo é entendido como oposto à unidade do Estado. Pelo contrário, o objetivo do federalismo é a unidade, respeitando e assimilando a pluralidade. [...] Para garantir a unidade (fim), o Estado possui determinada forma de organização (meio), mais ou menos centralizada. Todo Estado, inclusive o federal, neste sentido é unitário, pois tem como um de seus objetivos a busca da unidade.

Mesmo ponto abordado por Daniel Elazar (1991, p. 64):

Uma das características do federalismo é que ele aspira e objetiva simultaneamente gerar e manter ambos: unidade e diversidade. [...] Federalizar envolve tanto a criação e manutenção da unidade quanto a difusão do poder em nome da diversidade. De fato, isto é a razão do por que o federalismo não pode ser localizado num contínuo centralização-descentralização, mas num contínuo completamente diferente, que se baseia na não-centralização, ou na efetiva combinação de unidade e diversidade. Quando se discute o federalismo, é um erro apresentar unidade e diversidade como opostos. Unidade deveria ser contrastada com desunião e diversidade com homogeneidade, enfatizando a dimensão política e implicações de cada uma. ${ }^{9}$

Na obra "O princípio federativo", Proudhon (2001, p. 98) esclarece a origem latina da palavra federação, que significa 'contrato', e acrescenta: “O contrato de federação, cuja essência consiste em reservar sempre mais para os cidadãos que para o Estado, para as autoridades municipais e provinciais que para a autoridade central, poderia sozinho pôr-nos no caminho da verdade."

Jan Erk (2006, p. 104) destaca a diversidade das federações, buscando uma definição mínima para envolver toda essa multiplicidade:

\footnotetext{
${ }^{8}$ Tradução livre de: “A federation is a polity in which decision-making power is divided between central and regional governments. Many definitions include the notion that this division of power is constitutionally guaranteed and therefore conclude that only democracies can be truly federal because only in democratic political systems is it possible for these guarantees to be meaningful. Regardless of this dispute, the key issue is that federations do not merely decentralize administrative responsibilities, but also share the power to make authoritative political decisions."

${ }^{9}$ Tradução livre de: "One of the characteristics of federalism is its aspiration and purpose simultaneously to generate and maintain both unity and diversity. (...) Federalizing involves both the creation and maintenance of unity and the diffusion of power in the name of diversity. Indeed, that is why federalism is not to be located on the centralization-decentralization continuum but on a different continuum altogether, one that is predicated on non-centralization, or the effective combination of unity and diversity. When discussing federalism, it is a mistake to present unity and diversity as opposites. Unity should be contrasted with disunity and diversity with homogeneity, emphasizing the political dimensions and implications of each."
} 
Em termos procedimentais formais, federalismo existe como uma característica definidora de constituições em um número de países variando dos Estados Unidos a Índia. Esses sistemas federais dividem um mínimo denominador comum descritivo de uma estrutura política em que a autoridade política é dividida, compartilhada, ou dispersada entre dois ou mais níveis de governo. ${ }^{10}$

O caráter dinâmico das relações federativas é mencionado por Jonathan Rodden (2004, p. 489): Federalismo não é uma distribuição particular de autoridade entre governos, mas, ao contrário, um processo, estruturado por um conjunto de instituições, através das quais a autoridade é distribuída e redistribuída. ${ }^{11}$

No livro Federalism and Welfare State, em que se estudam políticas públicas em federações, Herbert Obinger, Stephan Leibfried e Francis G. Castles (2005, p. 8-9) enumeram características que seriam comuns a países federais, reconhecendo a dificuldade de alcançar a miríade de arranjos institucionais existentes:

[...] todas as federações existentes exibem diversas características institucionais comuns, que nos permitem classificá-las mais facilmente. Tendo uma visão mais ampla, nós podemos descrever o federalismo como 1. um conjunto de arranjos institucionais e regras de decisão ao nível do governo central para a incorporação dos interesses de base territorial; esses arranjos variam no grau em que eles oferecem poderes de veto para órgãos subordinados de governo; 2. um conjunto de atores baseado territorialmente com ideias e interesses que variam muito em número e heterogeneidade; 3. um conjunto de arranjos jurisdicionais para alocação de responsabilidades sobre políticas públicas entre os diferentes níveis de governo; isto se refere tanto à formulação, quanto à implementação da política pública; 4. um conjunto de arranjos de transferências fiscais intergovernamentais; e 5. um conjunto de arranjos informais - tanto vertical, quanto horizontal - entre governos. ${ }^{12}$

\footnotetext{
${ }^{10}$ Tradução livre de: "In formal procedural terms, federalism exists as a defining characteristic of constitutions in a number countries ranging from the United States to India. These federal systems share a descriptive lowest common denominator of a political structure in which political authority is divided, shared, or dispersed among two or more levels of government."

${ }^{11}$ Tradução livre de: "Federalism is not a particular distribution of authority between governments, but rather a process - structured by a set of institutions - through which authority is distributed and redistributed."

${ }^{12}$ Tradução livre de: "all existing federations exhibit several common institutional characteristics, which allow us to classify them more readily. Taking a broader view we may describe federalism as 1 . a set of institutional arrangements and decision rules at the central government level for incorporating territoriallybased interests; these arrangements vary in the degree to which they provide veto powers to subordinate branches of government; 2. a set of territorially-based actors with ideas and interests who vary greatly in number and heterogeneity; 3. a set of jurisdictional arrangements for allocating policy responsibilities between different levels of government; this refers to both policy-making and policy-implementation; 4 . a set of intergovernmental fiscal transfer arrangements; and 5. a set of informal arrangements-both vertical and horizontal-between governments."
} 
Desse modo, os autores (OBINGER; LEIBFRIED; CASTLES, 2005, p. 29), apesar de identificarem algumas características das federações, reconhecem a multiplicidade de desenhos que o federalismo pode apresentar e, consequentemente, a influência diferente que esse desenho pode representar em cada política pública:

[...] a diversidade de instituições federais entre os países, diferentes interfaces e ligações com instituições governamentais gerais, diferentes sistemas partidários e sistemas de mediação de interesses, bem como diferentes constelações de atores com preferências, estratégias e interesses heterogêneos, constituem uma ampla gama de configurações institucionais, tornando extremamente improvável que o federalismo possa ser associado com padrões uniformes de política social e trajetórias de desenvolvimento em todos os países. ${ }^{13}$

Diversidade de modelos também abordada por Oswaldo Aranha Bandeira de Mello (1948, p. 124):

Em conclusão, definimos o Estado federal: - Estado descentralizado por via de constituição rígida, em que os Estados federados são coletividades administrativa e constitucionalmente autônomas, e participam sempre, com maior ou menor extensão, nas deliberações da União. Naturalmente, entre os países classificados como Estado federal existe grandes diferenças de organização, mas pelo fato de possuírem aqueles característicos comuns fica o jurista autorizado a separá-los como formando um regime especial e diverso do de outros países, que se enquadram dentro do chamado Estado unitário.

A definição sintética de Celina Souza (2005, p. 105) abrange os elementos que ela considera principais: "Apesar das controvérsias sobre as principais características dos sistemas federativos, existe um consenso de que essa instituição tem duas dimensões principais: desenho constitucional e divisão territorial do poder governamental."

José Roberto Anselmo (2006, p. 88) destaca as características que compõe a autonomia dos entes federados:

Desfrutam os Estados-membros de autonomia, ou seja, capacidade de autodeterminação dentro do círculo de competências traçado pelo poder soberano, que lhes garante auto-organização, autogoverno, autolegislação e autoadministração, exercitáveis sem qualquer subordinação hierárquica dos Poderes estaduais aos Poderes da União.

\footnotetext{
${ }^{13}$ Tradução livre de: "The cross-country diversity of federal institutions, different interfaces and linkages with general governmental institutions, different party systems and systems of interest mediation, as well as different actor constellations with heterogeneous preferences, strategies and interests, constitute a broad range of institutional configurations, making it extremely unlikely that federalism will be associated with uniform patterns of social policy and similar developmental trajectories in all countries."
} 
Para José Afonso da Silva (2005, p. 100), a autonomia federativa é garantida por dois elementos basilares: “(a) na existência de órgãos governamentais próprios, isto é, que não dependam dos órgãos federais quanto à forma de seleção e investidura; (b) na posse de competências exclusivas, um mínimo, ao menos, que não seja ridiculamente reduzido.”

Diante dessas múltiplas visões acerca do federalismo, nesse trabalho, ele será definido como uma organização do Estado com a divisão de competências entre unidades locais e o governo central, definida constitucionalmente. A partir dessa definição jurídicoconstitucional, trataremos especificidades do federalismo brasileiro e, posteriormente, as relações federativas nas políticas públicas de habitação.

\section{Breve histórico do Federalismo no Brasil}

Por meio do decreto $\mathrm{n}^{\mathrm{o}} 1$, de 15 de novembro de 1889 foi proclamada provisoriamente e decretada a República Federativa, tendo sido o federalismo incorporado ao texto constitucional de 1891. No entanto, durante o Império, a questão da autonomia das Províncias e dos Municípios já havia gerado debates, como os escritos do Visconde do Uruguai e de Tavares Bastos, e revoltas, como a Confederação do Equador, conforme aponta José Murilo de Carvalho (1998, p. 164):

Transparece dos documentos da revolta uma reação à medida absolutista da dissolução da constituinte e à nova constituição, mas também uma resistência ao governo centralizado no Rio de Janeiro que estaria conspirando contra a liberdade das províncias, sobretudo a de Pernambuco.

$\mathrm{Na}$ Constituição de 1824, o território foi dividido em províncias e cada província tinha o número de senadores igual à metade do número de deputados, escolhidos pelo imperador, depois da eleição de uma lista tríplice. Cada província contava com um presidente nomeado pelo imperador e um conselho geral com membros eleitos, além de existirem câmaras nas cidades e vilas.

O Ato Adicional de 1834 teve uma tendência descentralizadora e foi seguido de revoltas pelo país, sucedidas por novas reformas, desta vez recentralizadoras (CARVALHO, 1993, p. 62):

Como solução de compromisso chegou-se à Reforma Constitucional de 1834, que adotou alguns elementos federais como as assembléias provinciais, a divisão dos ingressos fiscais e a eliminação do Conselho de Estado. [...] Houve cinco grandes revoltas depois da introdução da Reforma Constitucional. Começaram todas como conflitos entre elites locais na disputa pelo poder provincial. [...] A 
nova Câmara reformou as leis descentralizadoras, reduzindo o poder das assembléias provinciais e dos juízes de paz, criou uma justiça e uma polícia controladas pelo governo central. Com a intenção de deter as reformas, os liberais proclamaram a prematura maioridade do imperador em 1840. Os conservadores estavam de volta em 1841 e completaram o que se chamou o 'regresso' com o restabelecimento do Conselho de Estado. Havia terminado a experiência republicana semifederal. ${ }^{14}$

O Manifesto Republicano de 1870 defendia a descentralização como forma de manutenção da unidade. Nesse mesmo sentido, o movimento republicano tinha no federalismo seu maior apelo, conforme a abordagem de Carvalho (1993, p. 73): “A grande força por trás do movimento republicano, especialmente em São Paulo e no Rio Grande do Sul, era o federalismo e não a liberdade, ainda que os dois fossem apresentados como sinônimos." 15

Na Constituição de 1891 foi adotada a república federativa sob o nome de Estados Unidos do Brasil: os senadores passaram a ser três por Estado, aos Estados foi possibilitada a promulgação de constituições estaduais de acordo com os princípios constitucionais e houve a previsão da autonomia municipal (CARVALHO, 1998, p. 181):

Federalizar era necessariamente reforçar as estruturas sociais de poder preexistentes, era reforçar a desigualdade, a hierarquia, o privatismo. Não surpreende que o federalismo fosse bem-vindo aos poderes locais. A experiência do federalismo na Primeira República (1889-1930) foi exemplar. Existe quase consenso na literatura quanto ao fato de ter sido este o ponto alto do poder das oligarquias rurais na história independente do Brasil.

Segundo Celina Souza (2005, p. 107-8), durante o governo Vargas foi aprovada uma reforma eleitoral:

Concebida como forma de contrabalançar o poder de alguns poucos estados, no que ficou conhecida como a política dos governadores, a sobre-representação dos estados menos populosos permanece como um dos mecanismos voltados para o amortecimento das heterogeneidades regionais e como forma de acomodar as

\footnotetext{
${ }^{14}$ Tradução livre de: "Como solución de compromiso se llegó al la Reforma Constitucional de 1834 que adoptó algunos elementos federales como las asambleas provinciales, la división de los ingresos fiscales y la eliminación del Consejo de Estado. [...] Hubo cinco grandes revueltas después de la introducción de la Reforma Constitucional. Comenzaron todas como conflictos entre elites locales en disputa por el poder provincial. [...] La nueva Cámara reformó las leyes descentralizadoras, redujo el poder de las asambleas provinciales y de jueces de paz, creó una justicia y una policia controladas por el gobierno central. Con la intención de detener las reformas, los liberales proclamaron la prematura mayoria de edad del emperador en 1840. Pelo los conservadores estaban de regreso en 1841 y completaron lo que se llamó el "regreso" com el restablecimiento del Consejo de Estado. Había terminado la experiência republicana semifederal."

${ }^{15}$ Tradução livre de: "La gran fuerza detrás del movimiento republicano, especialmente en São Paulo y en Rio Grande do Sul, era el federalismo y no la libertad, aunque los dos fueron presentados como sinónimos."
} 
assimetrias de poder entre unidades territoriais que registram grandes diferenças econômicas.

A Constituição de 1934 reafirmou a república federativa e a autonomia municipal, mas um amplo rol de competências privativas foi destinado à União e reduzido para dois por Estado o número de senadores (SOUZA, 2000, p. 6):

Os governos subnacionais perdem parte do seu poder financeiro pela extinção de vários impostos e pela expansão das bases dos impostos federais. No entanto, a medida mais importante adotada pela constituição de 1934 foi delegar ao governo federal a competência para regular as relações fiscais externas e entre os estados. Ao negar às oligarquias regionais o direito de decidir sobre um dos mais importantes aspectos da sua vida econômica, ou seja, a definição das regras de trocas de mercadorias, Getúlio pavimentou o caminho para a industrialização, através da uniformização das regras fiscais.

Essa Constituição ainda previu a possibilidade de transferências para a União e para os Municípios dos recursos arrecadados, com a criação de novos impostos pela União ou pelos Estados.

Já a Constituição de 1937, apesar de ter assegurado em seu texto que o Brasil era uma república federal, proibiu quaisquer bandeiras, hinos, escudos e armas que não fossem os nacionais, possibilitou a transformação de Estados não solventes por três anos em territórios, declarou a autonomia municipal, mas estabeleceu que a escolha do prefeito seria feita pelo governador do Estado. Ainda criou a figura dos decretos-lei que possibilitaram ao Presidente da República legislar sobre diversas matérias.

A convivência do modelo das oligarquias regionais da República Velha com a nova centralização buscada por Vargas é abordada por Fernando Abrucio (2002, p. 34):

O modelo varguista não resolveu, em suma, dois dilemas básicos que marcaram as relações intergovernamentais: a dificuldade em estabelecer caminhos institucionais capazes de compatibilizar as demandas das elites regionais com uma visão nacional dos problemas do país e o descompasso entre a modernização (ainda que incompleta) das estruturas estatais do Governo Federal e a permanência de padrões patrimonialistas em quase todos os estados e municípios. Percebe-se, aqui, a força de alguns elementos presentes na fundação do federalismo, evidenciando que o varguismo foi um corte sim na estrutura federativa da Primeira República - sobretudo com o crescimento do poder da União -, mas não teve capacidade de destruir por completo o antigo modelo, convivendo com ele ou o modificando em parte, conforme o seu sucesso na negociação com as elites regionais. 
A Constituição de 1946 manteve a federação, foram readmitidos os símbolos municipais e estaduais e três senadores por Estado, e grande parte dos prefeitos pôde passar a ser eleito. A maior novidade sob o ponto de vista da federação foi o estabelecimento constitucional das transferências de recursos entre os entes federados (SOUZA, 2000, p. 6-7):

Essa constituição foi, ao mesmo tempo, centralizadora a favor do governo federal e localista porque transferiu vários impostos estaduais para os municípios e por fazer com que os estados passassem a transferir parte de seus impostos para os municípios. O mecanismo de partilha de impostos das unidades maiores da Federação para as menores foi a primeira tentativa de enfrentar a questão do desequilíbrio fiscal entre níveis de governo. Já o equilíbrio horizontal, isto é, entre entes da mesma esfera, foi timidamente introduzido através da vinculação de certos recursos federais que deveriam ser aplicados no Norte e no Nordeste.

A Constituição de 1967, assim como havia acontecido com a de 1937, declarou a federação como forma de organização do Estado, mas centralizou o poder no Executivo federal. Por meio do Ato Complementar $n^{\circ} 40 / 1968$, foram criados os fundos de participação dos Municípios, dos Estados e do Distrito Federal, e por meio do Ato Institucional n $n^{\circ} 3 / 1966$, as eleições para governadores e para diversas prefeituras passaram a ser indiretas, como aponta Abrucio (2002, p. 178):

Na verdade, os militares localizavam na Federação a maior fonte de provável oposição ao regime. Não por acaso a alteração da estrutura federativa era um objetivo explícito e fundamental da cúpula governante. Buscava-se aumentar a capacidade decisória do Executivo Federal e evitar a articulação oposicionista da elite civil nos estados, especialmente a que pertencesse aos quadros dos partidos do período anterior ao golpe de 64.

Ainda assim, a criação dos fundos de participação foi uma modificação relevante do período (SOUZA, 2005, p. 109):

No entanto, apesar da centralização dos recursos financeiros, foi a reforma tributária dos militares que promoveu o primeiro sistema de transferência intergovernamental de recursos da esfera federal para as subnacionais, por meio dos fundos de participação (Fundo de Participação dos Estados (FPE) e Fundo de Participação dos Municipios (FPM)). O critério de distribuição abandonou a repartição uniforme entre os entes constitutivos, passando a incorporar o objetivo de maior equalização fiscal pela adoção do critério de população e inverso da renda per capita. No regime militar, as esferas subnacionais também recebiam as chamadas transferências negociadas, que cresceram significativamente no período. 
Atualmente, o Fundo de Participação dos Municípios tem uma grande importância nas finanças dos Municípios brasileiros, especialmente os menores (IBGE, 2004, p. 39):

No caso dos municípios com até 5.000 habitantes, o FPM foi responsável por $57,3 \%$ das transferências correntes, reduzindo-se conforme aumentava o tamanho populacional dos municípios. Este comportamento mostra que o FPM foi um forte mecanismo de redistribuição de recursos para os pequenos municípios, além de estar concentrado mais fortemente fora da região mais dinâmica do País.

$\mathrm{Na}$ época, um aspecto bastante importante da relação do governo central com Estados e Municípios foram os convênios, instrumentos de suposta coordenação e que acabaram servindo para impor políticas centrais aos governos locais (ABRUCIO, 2002, p. 179):

O modelo de relações intergovernamentais no regime militar ficou marcado, portanto, por uma concepção autoritária e vertical. Nele, havia espaço para uma "cooperação" de mão única: os governos subnacionais tinham de obedecer e colaborar com os planos da União. Para tanto, foram utilizados os convênios, que repassavam recursos e assistência técnica, e uma série de ações conjuntas entre as estatais federais e estaduais, pois com o Decreto-Lei 200 (1967) descentralizou-se à administração indireta a realização da maioria dos programas de desenvolvimento e de intervenção no setor de infra-estrutura. Obviamente, caso estados e municípios se recusassem a participar deste jogo, ficariam sem o bônus das verbas e do apoio burocrático, e estariam alijados do processo de state building realizado pelo varguismo em seu período militar.

Nesse período, o repasse de recursos da União para os Estados em algumas políticas públicas como na de saneamento, estruturada no Plano Nacional de Saneamento (Planasa) e no Banco Nacional de Habitação (BNH), acabou priorizando regiões mais ricas, que contavam com maior capacidade de pagamento, já que era importante remunerar os recursos, como aponta Wilson Jorge (1988, p. 224):

Dessa forma, a lógica da concentração decorreu também da lógica financeira da instituição com o controle sobre os fundos do Plano. O Estado de São Paulo, mesmo pagando os juros mais caros do SFS (10,5\% ao ano) absorveu 42,6\% do total de investimentos realizados pelo PLANASA, no Brasil, de 1968 a 1984, seguido por Minas Gerais com 10,0\% do total dos investimentos.

Com a utilização dos recursos disponíveis no governo central, a União pressionou os Municípios a aderirem ao Planasa e às companhias estaduais em troca de dinheiro, fazendo com que os entes locais abrissem mão de decidir sobre sua política de saneamento, entre outras políticas, conforme aponta Geraldo Serra (1991, pp.62-63): 
Tendo em vista que, graças aos mesmos mecanismos financeiros de coação, os municípios perderam controle sobre os seus serviços autônomos de água e esgoto, verifica-se que boa parte da cidade passava agora a ser planejada, projetada, financiada e construída por entidades totalmente fora do controle da Prefeitura.

Desse modo, o país continuava sob o nome de Estado Federal, mas, na prática, pouca autonomia restava aos entes federados, tendo havido inclusive limitação das eleições para governador e prefeito de Municípios maiores, temas tratados por Brasílio Sallum Jr. (1996, p. 33): “A nova federação, por um lado, reduziu drasticamente o poder dos estados federados e, portanto, dos grupos dirigentes regionais, e, por outro, fez dos governantes estaduais executores de políticas públicas definidas no âmbito nacional.”

A importância do repasse de recursos do governo central foi tamanha que influenciou até a organização administrativa dos governos (SALLUM JR., 1996, p. 43):

As administrações estaduais tentaram reproduzir a estrutura da administração federal, criando secretarias correspondentes aos ministérios, estabelecendo sistemas de coordenação similares (cada estado tinha a sua secretaria do planejamento, como a vinculada à Presidência da República), e agências descentralizadas de função semelhante. Por exemplo: ao Departamento Nacional de Estradas de Rodagem (DNER) correspondiam, nas administrações estaduais, os Departamentos Estaduais de Estradas de Rodagem (DERs). Um especialista chama a atenção para o fato de que não se tratava apenas de repetir um esquema que era considerado tecnicamente superior, mas de facilitar, pela similaridade dos órgãos estaduais e federais, a transferência de recursos da União para os estados.

Desse modo, além da redução da autonomia no âmbito constitucional e legal, o regime militar limitou as políticas públicas desenvolvidas pelos Estados por meio do controle dos recursos financeiros e dos convênios de repasse (SALLUM JR., 1996, p. 43):

O governo central moldava, assim, grande parte das atividades dos governos estaduais com base na falta de autonomia político-partidária, militar e econômico-financeira dos governos estaduais e na relativa abundância de recursos, próprios ou de terceiros, controlados pela União, na possibilidade desta última condicionar a transferência de recursos para estados e municípios.

Essa conformação de autonomia extremamente limitada dos Estados é justificada por Alfredo Buzaid (1971, p. 40) pela busca do desenvolvimento e, especialmente, pela defesa da segurança nacional:

O propósito do constituinte não foi o de destruir as unidades federadas, cuja autonomia respeita, mas o de construir o nôvo Brasil, cuja grandeza depende do desenvolvimento integrado de tôdas as regiões. Estas não se confinam dentro dos 
limites territoriais de um Estado; abrangem amplas áreas que incluem vários Estados. A êsse novo tipo, que promove o desenvolvimento econômico com o máximo de segurança coletiva, ousamos denominar federalismo de integração.

Esse cenário de federalismo somente nominal vai se modificado com o enfraquecimento do regime, sendo que a recuperação das bases federais também colabora com o aprofundamento desse debilitamento (ABRUCIO, 2002, p. 181):

Foram elevadas também as transferências federais obrigatórias e voluntárias para estados e municípios, além de o Governo Federal ter afrouxado os limites de endividamento e ampliado as linhas de crédito. Mais do que isso, houve um paulatino restabelecimento da autonomia financeira que os governos subnacionais praticamente haviam perdido. É neste ponto que o movimento deixa de ser uma mera barganha e transforma-se em recuo ou mesmo perda de controle dos governos militares sobre o processo. Em 1978, os governos estaduais recuperaram a capacidade de definir as alíquotas do então ICM, antes decididas pelo Senado. Dali para diante, o avanço descentralizador continuou em linha ascendente até sua consolidação na Constituição de 1988.

\subsection{Federalismo a partir de 1988}

A Constituição de 1988 (CF88) afirma o Brasil como uma República Federativa (art. $1^{\circ}$ e art. 18) e a forma federativa como cláusula pétrea (art. 60), não sendo possível sua extinção por emenda constitucional. Na análise de Celina Souza (1999, p. 12):

O federalismo brasileiro incorpora hoje múltiplos centros de poder e pode ser caracterizado como um sistema complexo de dependência política e financeira entre esferas de governo, por caminhos e capacidades diferenciadas na provisão de serviços públicos e por grandes disparidades entre as regiões e no interior de uma mesma região.

Na nova Constituição, os Municípios foram alçados a entes federados, juntamente com a União, os Estados e o Distrito Federal, as competências foram redefinidas, assim como os tributos destinados a cada ente. No entanto, conforme já referido, não é apenas em âmbito constitucional que o federalismo se molda. Na década de 90, autores como Marta Arretche (2009) apontam a criação de leis federais com forte tendência centralizadora como a Lei Kandir e a Lei de Licitações.

Alguns modos de integração de políticas e serviços públicos são bastante frequentes nos Municípios brasileiros atualmente, como os consórcios (IBGE, 2011a, p. 41): "Entre as formas de articulações pesquisadas nos 4.497 municípios que declararam formalizar algum tipo de associação, em 73,3\% deles estava presente o consórcio público. Em seguida, 
46,6\% e 42,2\%, respectivamente, dos municípios, participavam de consórcios administrativos e de convênios de parceria com o setor privado." A proporção de consórcios varia de acordo com o parceiro escolhido, segundo dados da Munic (IBGE, 2011a): 10,5\% dos Municípios têm consórcio administrativo intermunicipal para a habitação, 46,8\% contam com consórcio estadual e 51,4\% consórcio federal. Os consórcios públicos intermunicipais na área de habitação somam $8,3 \%, 43,3 \%$, são estaduais e 52,3\%, federais.

Também visando a articulação das relações entre as esferas municipal e federal, criou-se, no âmbito da Secretaria de Relações Institucionais da Presidência da República, o Comitê de Articulação Federativa (decreto $\mathrm{n}^{\circ}$ 6.181/2007), formado por igual número de representantes do governo federal e de representantes de associações de Municípios. Também foram estabelecidas formas mais provisórias de integração entre os entes, como os Grupos de Gestão Integrada no Programa de Aceleração do Crescimento (PAC).

Cabe mencionar também a estruturação de microrregiões, aglomerações urbanas e regiões metropolitanas, que apesar de serem impostas pelos Estados e contarem com uma atuação bastante limitada até o momento, podem auxiliar na coordenação de serviços públicos e obras.

Os comitês de bacia hidrográfica, previstos na lei $n^{\circ}$ 9.433/1997, também podem ter importante papel na coordenação de ações dos entes federados, contando com a vantagem de forneceram uma base territorial adequada a um planejamento ambiental ligado a um planejamento urbano e regional.

Outros momentos de articulação entre os entes podem ser observados em conselhos e fóruns de secretários estaduais e municipais de políticas setoriais. Os secretários estaduais de habitação, cidades ou desenvolvimento urbano, por exemplo, se reúnem no Fórum Nacional de Secretários de Habitação e Desenvolvimento Urbano.

Surgem também sistemas de políticas públicas a fim de coordenar a atuação dos entes federados setorialmente, como aborda Gabriel Lotta e José Carlos Vaz. (2012, p. 12): Embora a literatura dê nomes e argumentos distintos a esse movimento (recentralização ou coordenação), a tendência apontada é de um fortalecimento do governo federal que passa a atuar como coordenador de políticas e diretrizes nacionais a serem implementadas pelos municípios e estados, numa lógica de padrões mínimos de atuação vinculados a repasse de recursos com incentivos e induções.

Nesse sentido, o governo federal buscou municipalizar a execução, mas não as decisões estratégicas das políticas públicas (SOUZA, 2004, p. 34): 
Assim, embora a descentralização tenha sido um dos objetivos dos constituintes de 1988, desenvolvimentos recentes apontam para a consolidação de políticas voltadas para a implementação de políticas sociais e não para o aumento da capacidade de decidir sobre onde e como investir os recursos.

\subsubsection{Municípios}

Os Municípios foram declarados como integrantes da Federação, sendo relevante mencionar que os entes locais gozaram de relativa autonomia já no período da colônia. No entanto, a mesma Constituição que os declara membros, os trata de maneira desigual em relação aos Estados. Em artigo sobre essa temática, Fernando Dias Menezes de Almeida (2009) comenta essas desigualdades: a previsão de 'lei orgânica' municipal e 'constituição' estadual, bem como a subordinação daquela a essa, a impossibilidade de controle de constitucionalidade de leis municipais em face da Constituição Federal por meio de Ação Direta de Inconstitucionalidade, a vedação da criação de tribunais de contas municipais, a inexistência de Poder Judiciário municipal, a possibilidade de intervenção do Estado no Município e a dependência do Estado para a criação de Municípios. Além disso, não existem defensorias públicas, ministérios públicos ou senadores que representem o interesse dos Municípios nas decisões acerca da legislação nacional ou estadual.

Nesse artigo, Almeida (2009, p. 83) critica essa tentativa de equiparação de entes que têm papéis diferentes dentro da Federação: “Com efeito, contrariando a natureza dos Municípios, sua pretensa equiparação aos Estados no contexto federativo induz a tendência, ou mesmo impõe aos Municípios a repetição do modelo de estruturação estatal federal e estadual, notadamente no aspecto de governo."

E conclui que a valorização dos Municípios não se dará com a aproximação do modelo de organização dos Estados, mas com a possibilidade de autonomia para uma organização adequada à realidade local (ALMEIDA, 2009, p. 85):

Se a Constituição Federal quer mesmo valorizar politicamente os Municípios e garantir-lhes autonomia real - e não apenas nominal -, deveria antes, portanto, seja diretamente, seja por impor parâmetros a serem desenvolvidos no âmbito do direito constitucional estadual - melhor esta segunda hipótese, pelo seu sentido de descentralização -, estabelecer meios para que os Municípios possam estruturar-se segundo modelos mais variados e adaptados à realidade nacional, garantidas suas competências legislativas e materiais. A verdadeira autonomia municipal, em suma, pressupõe adequação à realidade de fato, o que não pode 
ser antecipado, de modo geral e abstrato, segundo um modelo único aplicável nacionalmente.

Ainda sobre os Municípios, é importante destacar a criação deles, que no texto original da Constituição Federal de 1988 estava vinculada à legislação estadual, e passou, a partir da Emenda Constitucional $n^{\circ} 15 / 1996^{16}$, a depender também de lei complementar federal ainda não promulgada. ${ }^{17}$ No período de 1991 a 2000 haviam sido criados 1.016 Municípios, um acréscimo de $18 \%$ do total nacional (SILVA, Jorge Kleber Teixeira; LIMA, Maria Helena Palmer), como critica Almeida (2003, p. 317-318):

$\mathrm{O}$ argumento, válido sob certo aspecto, de tanto mais de valorizar a democracia quanto mais se aproximem representantes e representados e quanto mais se torne acessível à comunidade a discussão dos assuntos de interesse comum (o que certamente ocorre em comunidades menores), não se aplica exatamente à situação. Em primeiro lugar, este argumento, levado ao extremo, reconheceria apenas a democracia direta. Em segundo lugar, poderiam ser criados instrumentos de participação democrática inframunicipais, sem com isso multiplicarem-se os Municípios.

Posteriormente, a criação de Municípios se desacelerou, estando teoricamente inviabilizada $^{18}$, contando o país com 5.570 Municípios, com população variando de 805 a 11.253.503 habitantes. ${ }^{19}$

\subsubsection{Divisão de competências}

As competências são definidas por José Afonso da Silva (2005, p. 479) como "as diversas modalidades de poder de que se servem os órgãos ou entidades estatais para realizar suas funções.”

\footnotetext{
${ }^{16}$ A emenda Constitucional $n^{\circ} 57 / 2008$ convalidou a criação de Municípios que tivesse sido efetuada até 31.12.2006.

${ }^{17}$ Há uma Ação Direta de Inconstitucionalidade por omissão julgada procedente no Supremo Tribunal Federal em 2007. (STF, Tribunal Pleno, ADI 3682/MT. Julgamento: 09.05.2007). O projeto de lei complementar $n^{\circ}$ 416/2008 estabelecia população mínima para a criação de Municípios: 5.000 para regiões norte e centro-oeste, 7.000 para a região nordeste e 10.000 para as regiões sul e sudeste, além de outros requisitos como a existência de núcleo urbano constituído, um patamar mínimo de imóveis e de arrecadação. Depois de votado, o projeto foi vetado totalmente pela presidenta.

${ }^{18}$ Ainda que haja essa inviabilidade, após o Censo de 2010, foram criados cinco novos Municípios.

${ }^{19}$ Borá/SP e São Paulo/SP, respectivamente. BRASIL. Ministério do Planejamento, Orçamento e Gestão. Instituto Brasileiro de Geografia e Estatística - IBGE. Sinopse do Censo Demográfico 2010. Rio de Janeiro: 2011.
} 
O desenho constitucional da federação brasileira em 1988, apesar de contar com um rol extenso de competências comuns entre os entes federados, entrega diversas matérias à União, restando bastante limitadas as competências subsidiárias dos Estados, conforme aborda Fernanda Dias Menezes de Almeida (1991, p. 174):

A análise das competências privativas de cada esfera de poder revela uma clara preponderância do poder federal, um certo fortalecimento do poder municipal e a permanência da situação desconfortável do poder estadual, cujos poderes remanescentes continuaram esvaziados de conteúdo e significado prático.

Além disso, a própria divisão de competências se mostra ambígua na prática das federações, o que pode resultar em centralização (Paulo de Bessa ANTUNES, 2007, p. 301): "Ocorre que, em não raras oportunidades, as Constituições se utilizam de fórmulas gerais e ambíguas que, por meio de interpretações jurisprudenciais, em muitas oportunidades, conduzem a um modelo-centrípeto."

Conforme menciona Fernando D. M. de Almeida (2008, p. 219), a distribuição de competências legislativas também estabelece uma preponderância da União:

E, de sua parte, a União segue inercialmente uma tendência de concentração de rendas e poderes - poderes não apenas politicos, mas politico-jurídicos. Sim, pois a repartição de competências legislatives vigente denuncia também uma desproporcional concentração de temas relevantes na esfera da União.

A CF de 1988, em sua redação original, previu a fixação de normas para a cooperação entre União, Estados, Distrito Federal e Municípios nas competências comuns por meio de uma lei complementar. A emenda constitucional $n^{\circ} 53 / 2006$ modificou a redação, abrindo a possibilidade de diversas leis complementares fixarem essas regras.

A primeira delas a ser publicada foi a lei complementar $n^{\circ} 140 / 2011$, que fixa normas "para a cooperação entre a União, os Estados, o Distrito Federal e os Municípios nas ações administrativas decorrentes do exercício da competência comum, relativas à proteção das paisagens naturais notáveis, à proteção do meio ambiente, ao combate à poluição em qualquer de suas formas e à preservação das florestas, da fauna e da flora". Essa lei, além de explicitar melhor o papel de cada ente dentro da política ambiental, cria instrumentos como as Comissões Tripartites Nacionais e Estaduais para fomentar a "gestão ambiental compartilhada e descentralizada" entre os entes federados.

Fernanda Dias Menezes de Almeida (1991, p. 144), em trabalho de análise da Constituição, logo após sua promulgação, colocava suas esperanças de estabelecimento de regras de funcionamento das relações entre os entes federados nessas leis, que, com a mencionada exceção, ainda não foram promulgadas: 
Pelas razões que acabamos de expor, pensamos que à lei complementar prevista no artigo 23, parágrafo único, caberá fixar as bases políticas e as normas operacionais disciplinadoras da forma de execução dos serviços e atividades cometidos concorrentemente a todas as pessoas políticas.

As competências comuns, como as políticas públicas de saúde e educação, têm diferentes graus de coordenação estabelecidos pela Constituição. Na educação, por exemplo, a divisão foi melhor delineada com o estabelecimento da responsabilidade dos entes: a União "exercerá, em matéria educacional, função redistributiva e supletiva, de forma a garantir equalização de oportunidades educacionais e padrão mínimo de qualidade do ensino mediante assistência técnica e financeira aos Estados, ao Distrito Federal e aos Municípios" (art. 211 da CF), "os Municípios atuarão prioritariamente no ensino fundamental e na educação infantil" (art. 211, $\S 2^{\circ}$ da CF) e "os Estados e o Distrito Federal atuarão prioritariamente no ensino fundamental e médio" (art. 211, § $3^{\circ}$ da CF).

No entanto, em algumas políticas públicas de competência comum, como a promoção de programas de construção de moradias e melhoria das condições habitacionais (art. 23, IX da CF), os entes federados não tem claro como se dará essa coordenação, cabendo à legislação infraconstitucional e à Administração Pública delimitar suas áreas de atuação.

\subsubsection{Tributos}

Ao contrário das demais matérias, nas questões tributárias, a competência residual é da União (art. 154) e não dos Estados. Já o imposto que representa a maior arrecadação ${ }^{20}$, sobre operações relativas à circulação de mercadorias e sobre prestações de serviços de transporte interestadual e intermunicipal e de comunicação (ICMS), coube aos Estados, bem como o imposto sobre transmissão causa mortis e doação, de quaisquer bens ou direitos (ITCMD), e o imposto sobre a propriedade de veículos automotores (IPVA).

Os impostos dos Municípios ficaram limitados ao imposto sobre a propriedade predial e territorial urbana (IPTU); ao imposto sobre transmissão "inter vivos", a qualquer título, por ato oneroso, de bens imóveis, por natureza ou acessão física, e de direitos reais sobre imóveis (ITBI); e ao imposto sobre serviços de qualquer natureza não compreendidos no ICMS (ISS).

\footnotetext{
${ }^{20}$ A arrecadação do ICMS no ano de 2002 foi de R \$ 102,952 milhões, seguido pelo Imposto de Renda que arrecadou R\$75,551 milhões (Marcos Mendes, 2005, p. 442).
} 
Os impostos que foram destinados aos Municípios têm maior base de arrecadação em Municípios com maiores índices de urbanização e maior rede de serviços, além de apresentarem algumas outras limitações (SOUZA, 2004, p. 33):

Primeiro, o sistema tributário nacional é concentrado em impostos que incidem sobre a produção, vendas e consumo, os quais não estão sob a jurisdição municipal. Segundo, os impostos locais, principalmente o ISS e o IPTU, requerem a existência de bancos de dados, cadastros e atualizações dispendiosos e complexos, além de incidirem sobre um grande universo de contribuintes, em particular de pequenos negócios, como é o caso do ISS. Terceiro, os impostos locais apresentam limitações em países como o Brasil, onde os níveis de pobreza são altos e os serviços passíveis de cobrança de ISS ou não existem em pequenas localidades ou são de pequeno porte e instáveis.

Em estudo recente do Ministério das Cidades (Marta ARRETCHE et al., 2007, p. 136), constatou-se a grande quantidade de Municípios com baixa arrecadação própria:

Nada menos que $85 \%$ dos municípios do Norte e $93 \%$ do Nordeste são fortemente dependentes das transferências constitucionais, pois arrecadam menos de $10 \%$ de suas receitas. Sul, Sudeste e Centro-Oeste apresentam percentual ainda importante de seus municípios com essa característica: 67,6\%, $63,8 \%$ e $66,2 \%$, respectivamente.

O mesmo estudo (ARRETCHE et al., 2007, p. 146.) demonstra que muitos Municípios não são vítima de 'preguiça tributária', mas sofrem limitações por suas características e pela natureza dos tributos de sua competência:

Nas regiões Sul, Sudeste e Centro-Oeste, maior esforço tributário, particularmente dos municípios de médio porte, poderia ter impacto tributário relevante, dado seu alto potencial de arrecadação. Nas regiões Norte e Nordeste, incentivos à elevação da arrecadação tributária municipal não teriam significativo impacto nos níveis de arrecadação, dada sua base de tributação comparativamente menos dinâmica.

Além dos impostos, taxas e contribuições de melhoria, os Municípios e Estados contam com transferências de recursos.

\section{Federalismo Fiscal}

As teorias do federalismo fiscal estudam e buscam determinar as relações mais eficientes entre arrecadação e gastos entre os entes federados, conforme síntese de Marcos Mendes (2005, p. 423): “Assim, pode-se dizer que o federalismo fiscal procura estabelecer 
parâmetros de racionalidade e eficiência econômica que orientem os ajustes na organização das federações, à medida que o processo político permita tais alterações."

Como não dizem respeito ao aspecto político, dando destaque ao economicamente razoável, as teorias do federalismo fiscal podem ser utilizadas em países unitários, na busca de melhores arranjos entre quem gasta e quem arrecada; assim como a descentralização, essas teorias não se limitam ao estudo das federações. A preocupação central é superar a limitação dos Estados em conhecerem as preferências dos seus cidadãos, já que as relações são diferentes de um mercado e de sua regulação com o sistema de preços.

As teorias esclarecem a relação entre a heterogeneidade da federação e a autonomia dos entes federados, o que é um fator importante a se considerar no caso brasileiro, como esclarecem Waldemir Quadros e Carlos Cavalcanti (2003, p. 20.): "Quanto maior a homogeneidade socioeconômica do espaço nacional, portanto, maior escopo para ampliar as autonomias orçamentárias subnacionais. Ao contrário, federações marcadas por desigualdades elevadas requerem sistemas fiscais mais centralizados."

Uma das críticas a essas teorias é justamente o excessivo destaque a questões econômicas, desconsiderando outras relações nos Estados federais, segundo Rui de Britto Alvares Affonso (2004, p. 194):

Nessa teoria, assim como o Estado é tomado como um dado exógeno, o Estado federal e as razões histórico-concretas ou teórico-abstratas de sua adoção não são objeto de análise. Opera-se, assim, uma separação conceitual entre os determinantes da adoção de uma estrutura federativa e os determinantes do seu funcionamento. Como determinante central (e exclusivo nessa teoria) do funcionamento de um Estado federal, teríamos a procura por um Estado federal “eficiente", isto é, dado que a estrutura estatal em pauta é federativa, indaga-se como deveriam organizar-se os diferentes níveis de governo (basicamente quanto à sua divisão de competências), de modo a cumprir as funções de qualquer Estado: a alocativa, a distributiva e a de estabilização, da forma mais eficiente.

Outras críticas feitas a esses modelos teóricos podem ser relacionadas, como a assunção de que a principal diferença entre as jurisdições locais está baseada em gostos ou preferências, e não na renda, sendo que, conforme aponta Remy Prud'Homme (1995, p. 208): na maioria dos países em desenvolvimento, o problema não é revelar as diferenças delicadas nas preferências entre jurisdições, mas satisfazer necessidades básicas, que são - 
pelo menos, a princípio - muito bem conhecidas. ${ }^{21}$ Cabe ainda observar suas críticas sobre as limitações do modelo de redistribuição entre jurisdições (PRUD’HOMME, 1995, p. 202): Não há garantia, entretanto, que as transferências para áreas de baixa renda efetivamente beneficiarão os residentes mais pobres. ${ }^{22}$

Alguns teóricos apontam como modelo ideal uma arrecadação centralizada com a execução das políticas públicas mais próxima do nível local ${ }^{23}$, o que geraria um problema de alocação de recursos entre os níveis de governo. A resposta dada a esse descompasso seria as transferências de recursos entre os entes federados (MENDES, 2005, p. 434-5):

Quando se comparam as prescrições para a alocação eficiente de tributos e de gastos entre níveis de governo, o que se observa é que são passíveis de descentralização diversas ações públicas ao mesmo tempo em que é muito restrito o conjunto de tributos que pode ser arrecadado de forma eficiente pelos governos municipais e estaduais. O resultado é um desequilíbrio entre receitas e despesas desses governos, que ficou conhecido, na literatura, pela expressão desequilíbrio vertical. Esse é um dos motivos para a implementação de transferências financeiras intergovernamentais, que em geral vão do governo central para estados e municípios e dos estados para os municípios.

\subsection{Transferências intergovernamentais}

As transferências podem ser estabelecidas constitucional e legalmente, ou serem discricionárias, além de poderem ser vinculadas a contrapartidas ou não. Elas auxiliam, entre outras coisas, nesse balanço entre arrecadação tributária e implementação de políticas públicas.

As transferências discricionárias são bastante dependentes de negociações políticas, mas também permitem maior dinamismo, podendo haver alterações decorrentes de algum

\footnotetext{
${ }^{21}$ Tradução livre de: "in most developing countries, the problem is not to reveal the fine differences in preferences between jurisdictions but to satisfy basic needs, which are-at least in principle-quite well known."

${ }^{22}$ Tradução livre de: "There is no guarantee, however, that transfers to low-income areas will effectively benefit poorer residents."

${ }^{23} \mathrm{O}$ princípio mais claro e mais importante (freqüentemente referido como subsidiariedade) é que os bens e serviços públicos deveriam ser prestados pelo mais baixo nível de governo que pode capturar totalmente os custos e os benefícios. Tradução livre de: "The clearest and most important principle (often referred to as subsidiarity) is that public goods and services should be provided by the lowest level of government that can fully capture the costs and benefits." WORLD BANK. World Development Report 1997 - the state in a changing world, New York: Oxford University, volume 1, p. 121.
} 
evento excepcional ou mudanças nas necessidades dos entes subnacionais ocorridas ao longo do tempo. Sob o ponto de vista do órgão receptor, as transferências vinculadas a um fim limitam o grau de autonomia na aplicação dos recursos. No entanto, conforme Quadros e Cavalcanti, elas (2003, p. 25.) "[...] tendem a propiciar maior uniformidade nos padrões de dispêndio per capita entre jurisdições caracterizadas por elevada heterogeneidade econômica e social."

Em estudo acerca dos gastos federais no período de 2001 a 2011, o Instituto de Pesquisa Econômica Avançada (IPEA, 2011a, p. 17) concluiu que a tendência dos últimos anos é o repasse de recursos para os entes subnacionais:

O macrodiagnóstico indica, portanto, que o governo federal está consolidando um padrão de intervenção que se revela mais canalizador ou redistribuidor de recursos, cujos efeitos sobre a economia são indiretos no que diz respeito à oferta e demanda de bens e serviços, tornando-se financiador indireto de parcela considerável do consumo das famílias e das despeses de consumo e investimento dos governos subnacionais. Esse quadro é muito distinto do senso comum que tem se cristalizado no Brasil em torno da percepção de que o governo central é "gastador" e "concentrador" de recursos. Esse padrão de intervenção governamental via transferências apresenta impactos redistributivos sobre a renda nacional, tanto no âmbito da distribuição social quanto federativa.

No entanto, esses repasses podem vir carregados de decisões, políticas, diretrizes e controle, o que influencia no grau de independência daqueles que recebem os recursos.

\section{Federalismo e descentralização}

Conforme já mencionado para o federalismo fiscal, a descentralização também não é exclusiva de países federados, já que os arranjos institucionais e a delegação de competências de execução de políticas públicas aos entes locais existem mesmo em países unitários descentralizados.

Daniel Elazar (1991, p. 34-5) defende que haveria uma diferença entre os conceitos de descentralização e não-centralização:

Não-centralização não é o mesmo que descentralização, embora esse último termo seja frequentemente - e erroneamente - usado em seu lugar para descrever sistemas federais. Descentralização implica a existência da autoridade central, um governo central que pode descentralizar ou recentralizar conforme deseja. Em sistemas descentralizados, a difusão do poder é realmente uma questão de Graça, não direito; e por fim, é normalmente tratada como tal. Em um sistema 
político não-centralizado, o poder é tão difundido que não pode ser legitimamente centralizado ou concentrado sem destruir a estrutura e o espírito da constituição. ${ }^{24}$

Nesse sentido, também há a distinção entre descentralização política e administrativa de Maria Sylvia Zanella Di Pietro (2009, pp. 409-410), que afirma que:

A descentralização política ocorre quando o ente descentralizado exerce atribuições próprias que não decorrem do ente central; é a situação dos Estadosmembros da federação e, no Brasil, também dos Municípios. Cada um desses entes locais detém competência legislativa própria que não decorre da União nem a ela subordina, mas encontra seu fundamento na própria Constituição Federal. As atividades jurídicas que exercem não constituem delegação ou concessão do governo central, pois delas são titulares de maneira originária.

Já a descentralização administrativa seria mais próxima ao sistema descentralizado de Elazar (DI PIETRO 2009, p. 410): “A descentralização administrativa ocorre quando as atribuições que os entes descentralizados exercem só têm o valor jurídico que lhes empresta o ente central; suas atribuições não decorrem, com força própria, da Constituição, mas do poder central."

A descentralização de políticas públicas no Brasil não esteve ligada apenas a um fator de racionalidade administrativa, mas se relacionou com diversos movimentos internos e externos, tendo sido desigual ao depender da política a ser descentralizada, seu histórico, seus atores, suas características. Como bem observa Celina Souza (1999, p. 3):

O federalismo é uma das instituições que foram reconstruídas após a redemocratização e a descentralização. No entanto, as mudanças ocorridas não devem ser vistas como um movimento radical da centralização para a descentralização. Isto porque o federalismo brasileiro não se formou pela dicotomia entre centralização versus descentralização, mas sim por um continuum entre esses processos, o qual sempre guiou as relações de poder entre as esferas central, regionais e locais.

Numa conjuntura internacional, a reforma gerencialista da Administração Pública em diversos países, recomendada por organismos internacionais como Banco Mundial e Banco Interamericano de Desenvolvimento (BID) indicava a descentralização para os países, especialmente para aqueles em desenvolvimento, bem como outras políticas como a

\footnotetext{
${ }^{24}$ Tradução livre de: "Noncentralization is not the same as decentralization, though the latter term is frequently - and erroneously - used in its place to describe federal systems. Decentralization implies the existence of a central authority, a central government that can decentralize or recentralize as it desires. In decentralized systems, the diffusion of power is actually a matter of Grace not right; in the long run, it is usually treated as such. In a noncentralized political system, power is so diffused that it cannot be legitimately centralized or concentrated without breaking the structure and spirit of the constitution."
} 
privatização. Celina Souza e Inaiá Mello (1999) abordam algumas das críticas a essas recomendações dos organismos internacionais, como a despolitização da Administração Pública com a defesa de uma tecnicidade eficiente, a complexidade dos problemas sendo tratados de maneira igual em países extremamente desiguais entre si, as contradições das teorias apresentadas e a importância da retórica na defesa de um modelo de reforma administrativa que dificilmente pode ser considerado, de maneira objetiva, o melhor.

O Banco Mundial (1997, p. 125) culpa o modo como se deu a descentralização pelo seu fracasso em alguns países, afastando uma crítica específica ao modelo e, inclusive, utiliza o Brasil como mau exemplo na execução da descentralização, com críticas direcionadas especialmente à falta de definição de responsabilidades e de capacidade administrativa dos governos locais, o que teria prejudicado seus resultados:

A experiência do Brasil mostra que a descentralização política e fiscal não garante a eficiência do setor público, e pode ameaçar a estabilidade macroeconômica. Para atingir seus objetivos, a descentralização fiscal deve ser acompanhada de uma descentralização correspondente às responsabilidades de gasto; as capacidades institucionais dos governos estaduais e municipais deveriam ser melhoradas, e o governo federal deveria impor orçamentos rígidos em suas relações fiscais e financeiras com os governos subnacionais. ${ }^{25}$

\section{Federalismo e políticas públicas}

Maria Paula Dallari Bucci (2006, p. 39) define a política pública como:

[...] o programa de ação governamental que resulta de um processo ou conjunto de processos juridicamente regulados - processo eleitoral, processo de planejamento, processos de governo, processo orçamentário, processo legislativo, processo administrativo, processo judicial - visando coordenar os meios à disposição do Estado e as atividades privadas, para a realização de objetivos socialmente relevantes e politicamente determinados.

A mesma autora (BUCCI, 2006, p. 44) destaca a necessidade de coordenação no desenvolvimento das políticas públicas, já que essa sucessão de processos a exige para a consecução dos fins:

\footnotetext{
${ }^{25}$ Tradução livre de: "Brazil's experience shows that political and fiscal decentralization does not guarantee improved public sector efficiency, and may threaten macroeconomic stability. To achieve its objectives, fiscal decentralization must be accompanied by a corresponding decentralization of expenditure responsibilities; state and municipal governments' institutional capacities should be improved; and the federal government should impose hard budgets in its fiscal and financial relation-ships with subnational governments."
} 
Pensar em política pública é buscar a coordenação, seja na atuação dos Poderes Públicos, Executivo, Legislativo e Judiciário, seja entre os níveis federativos, seja no interior do Governo, entre as várias pastas, e seja ainda considerando a interação entre organismos da sociedade civil e o Estado.

Alguns estudos relacionam a influência do modelo de Estado federal sobre as políticas públicas, como Paul Pierson (1995, p. 451), que afirma que a questão que o federalismo acrescenta é 'Quem?': Para os 'policymakerss ${ }^{26}$, sistemas federais sobrepõem a questão de "quem deveria fazer isto?" sobre a questão tradicional "o que deve ser feito?" 27

As federações têm que lidar com as demandas que existem em todos os países, além das disputas territoriais que as tornam mais complexas (PIERSON, 1995, p. 463):

[...] o processo de desenvolvimento da política social em sistemas federais não é inteiramente diferente daquele do desenvolvimento de política social em sistemas políticos mais centralizados; os conflitos de classe sobre o grau e a característica da intervenção governamental, por exemplo, são suscetíveis de serem encontrados em ambos. No entanto, o federalismo altera tanto o terreno para esses conflitos tradicionais como introduz atores e questões inteiramente novos. $^{28}$

A relação do federalismo com os direitos sociais envolve a busca de um equilíbrio entre a necessidade de um nível básico de direitos sociais garantido a todos de maneira uniforme, com a dinâmica de uma federação que tem entes com autonomia para decidir sobre os direitos que vão ser priorizados (OBINGER, LEIBFRIED; CASTLES, 2005, p. 3):

Central para a idéia de proteção social é a provisão de direitos sociais uniformes em toda a nação que complementem os direitos civis e políticos básicos. Daí pode-se assumir que política social em estados federais gera múltiplas tensões e é propensa a conflitos sobre quem deve conseguir o que, a que nível de governo deve ser confiada a criação de programas sociais e - provavelmente o mais

\footnotetext{
${ }^{26}$ A expressão 'policymaker' não tem tradução adequada ao português, mas diz respeito às pessoas que fazem políticas públicas.

${ }^{27}$ Tradução livre de: "For policymakers, federal systems superimpose the question of "who should do it?" over the traditional question of "what is to be done?"

${ }^{28}$ Tradução livre de: "the process of social policy development in federal systems is not entirely dissimilar to that of social policy development in more centralized polities; class-based conflicts over the degree and character of government intervention, for example, are likely to be evident in each. Yet federalism both alters the terrain for these traditional conflicts and introduces entirely new actors and issues."
} 
importante - que nível de governo deve arcar com os custos dos gastos

envolvidos. ${ }^{29}$

Desse modo, um dos conflitos presentes em países federativos é a garantia desses direitos básicos uniformes e a autonomia de cada ente. No caso brasileiro, a falta de capacidade administrativa e financeira de alguns Estados e Municípios torna essa dinâmica ainda mais complexa.

\section{Políticas públicas e Direito Administrativo}

O estudo de políticas públicas tem sido mais desenvolvido pela Ciência Política e pela Ciência da Administração Pública. Recentemente, os juristas tem se voltado ao estudo do tema, especialmente sob um viés processualista, motivados pelas decisões judiciais que alteraram e até mesmo criaram ${ }^{30}$ políticas públicas.

No campo do Direito Administrativo, poucos estudos tratam as políticas públicas como objeto, ainda mais sob um viés de coordenação dentro de uma federação, ou seja, da organização da Administração Pública, de cada um dos seus diferentes entes, no fornecimento de bens, políticas e serviços públicos aos administrados, segundo determinações constitucionais e legais.

A importância do Direito Administrativo se debruçar sobre a questão das políticas públicas se relaciona à importância da Administração Pública concretizar direitos, especialmente os sociais, à população, segundo Bercovici (2005, p. 60): “A Constituição também depende da Administração Pública para ser concretizada. [...] A necessidade de construção de um Direito Administrativo dinâmico, a serviço da concretização dos direitos fundamentais e da Constituição é cada vez mais necessária."

As políticas públicas podem ter diferentes suportes legais, ou mesmo, não serem previstas em leis (BUCCI, 2006, p. 11): "Podem ser expressas em disposições constitucionais, ou em leis, ou ainda em normas infralegais, como decretos e portarias e até

\footnotetext{
${ }^{29}$ Tradução livre de: "Central to the idea of social protection is the provision of nation-wide uniform social rights that supplement basic civil and political rights. Hence one may assume that social policy in federal states generates multiple tensions and is prone to conflicts over who should get what, which tier of government should be entrusted to set up social programmes and-probably most important-which level of government should bear the costs of the spending involved."

${ }^{30}$ Em São Paulo, a falta de uma política de atendimento aos autistas levou o Judiciário a criar uma política pública. Ao contrário de outras decisões que apenas encaram uma questão de distribuição de uma política já existente, neste caso, a política foi desenhada pelo Poder Judiciário: TJSP, Ap 278801-5/8-00, 3. ${ }^{a}$ Câm. de Direito Público, julgamento: 26.04.2005.
} 
mesmo em instrumentos jurídicos de outra natureza, como contratos de concessão de serviço público, por exemplo.” Conforme afirma Maria Paula Bucci (2006, p. 31):

As políticas públicas não são, portanto, categoria definida e instituída pelo direito, mas arranjos complexos, típicos da atividade político-administrativa, que a ciência do direito deve estar apta a descrever, compreender e analisar, de modo a integrar à atividade política os valores e métodos próprios do universo jurídico.

Relevante observação da mesma autora (BUCCI, 2006, p. 43) diz respeito ao aspecto jurídico do estudo de uma política pública: "O ideal de uma política pública, vista pelo direito, não se esgota na validade, isto é, na conformidade do seu texto com o regramento jurídico que lhe dá base, nem na eficácia jurídica, que se traduz no cumprimento das normas do programa."

Uma visão restrita a uma observação sobre a validade ou eficácia jurídica seria pouco útil à observação da realidade e do impacto de uma política pública, sendo mais relevante o estudo da eficácia social ou efetividade. Nesse sentido, Luís Roberto Barroso (2009, pp.82-83) comenta:

A efetividade significa, portanto, a realização do Direito, o desempenho concreto de sua função social. Ela representa a materialização, no mundo dos fatos, dos preceitos legais e simboliza a aproximação, tão íntima quanto possível, entre o dever-ser normativo e o ser da realidade social.

\section{Sistemas de políticas públicas}

Têm sido criados sistemas de políticas públicas no Brasil visando a integração da ação dos entes federados em determinados setores. A política que é vista como modelo é a da saúde, onde comissões tripartites e bipartites auxiliam na construção das normativas com a participação de todos os entes, conforme descrição de Abrucio (2011, p. 127):

Desde a promulgação da Constituição e da Lei Orgânica (1990), passando pelas Normas Operacionais Básicas (NOBs) 1993 e 1996, três instrumentos principais de coordenação instalaram-se: a criação de fóruns e arenas interfederativas de discussão, negociação e deliberação; o estabelecimento de um piso de atenção básica para todos os municípios - o PAB -, como maneira de enfrentar a desigualdade; e a União começou a repassar recursos extras aos governos que adotassem políticas consideradas importantes nacionalmente - como o Programa Saúde da Família (PSF) -, induzindo os entes federativos a adotar tais programas. 
Enquanto o Sistema Único de Saúde (SUS) ${ }^{31}$ é tomado como exemplo, autores como Alcides Silva de Miranda (2003, p. 223) apontam um funcionamento centralizado:

A persistência de uma distribuição ainda muito desproporcional de poder econômico, político e administrativo entre as esferas de governo, em dissonância com as premissas normativas estabelecidas constitucionalmente para o pacto federativo; O fluxo unidirecional de decisões e uso constante de normas ad hoc, principalmente por parte do Ministério da Saúde, sem a necessária negociação intergovernamental sobre a sua pertinência e oportunidade; A preponderância das demandas do nível federal de governo na definição da agenda decisória; A pouca transparência na discussão sobre a utilização dos recursos e gastos financeiros estaduais em saúde; A ausência de uma legislação que defina de modo mais preciso as funções e prerrogativas das Comissões Intergestores de Saúde.

Há autores como Gilson Carvalho (2001) que criticam a gestão da saúde por meio de NOBs/NOAS, por sua tendência centralizadora e desrespeito ao desenho estabelecido constitucional e legalmente; por outro lado, é no âmbito do SUS que se tem propiciado novos arranjos regionalizados, incentivos à consorciação e pactos pela saúde com adesão voluntária pelos entes, para contornar algumas deficiências na sua operação.

O modelo do SUS conta ainda com o Piso de Atenção Básica (PAB) composto de uma parte fixa definida por tamanho do Município e pontuação e uma parte variável dependente da adesão a programas definidos pelo governo federal com transferências fundo a fundo e com a necessidade de planos. No entanto, ainda há limitações, especialmente quanto ao papel dos Estados, conforme observação de Fernando Abrucio, Cibele Franzese e Hironobu Sano (2010, p. 33-4):

Embora esta área seja a que mais tenha consorciamentos intermunicipais no Brasil, a descoordenação e a competição ainda ocorrem entre as redes municipais. Isto se torna mais grave nas Regiões Metropolitanas, onde o fenômeno produz uma enorme desarticulação entre as cidades e o "efeito carona" é bastante presente. Outro problema é a indefinição do papel do governo estadual, tanto o de executor, como principalmente o de coordenador da relação entre as municipalidades. A situação mal resolvida dos estados no arranjo federativo da Saúde tem implicações inclusive financeiras, pois a maioria deles não gasta o percentual definido pela Emenda Constitucional 29, aprovada em 2002.

\footnotetext{
${ }^{31}$ Previsto na Constituição de 1988 e regulamentado pela lei $n^{\circ} 8.080 / 1990$ e pela lei $n^{\circ} 8.142 / 1990$. O SUS foi se estruturando especialmente a partir de Normas Operacionais Básicas (NOBs) e Normas Operacionais da Assistência à Saúde (NOAS).
} 
Outros sistemas ${ }^{32}$ foram criados, como o Sistema Único da Assistência Social, Sistema Nacional da Cultura, Sistema Nacional do Meio Ambiente ${ }^{33}$, Sistema Único de Segurança Pública e Sistema Nacional de Educação, como observa Nelson Saule Jr. (2007, p. 116):

O modelo de sistemas nacionais sobre campos de atuação dos entes federativos na promoção de políticas públicas tem como finalidade viabilizar um sistema institucional e administrativo dirigido ao estabelecimento de relações de cooperação, coordenação, articulação e integração entre as unidades da Federação com controle social.

Em outras áreas, a integração resulta de outros arranjos, sendo importante ressaltar que a coordenação federativa não se dá apenas no âmbito dos proclamados sistemas de políticas públicas. Por vezes, políticas mais coordenadas são estabelecidas sem a criação de estruturas ou legislações autodenominadas sistemas.

Em uma análise que englobou nove diferentes áreas de políticas públicas, Gonçalves, Lotta e Bitelman (2008, p. 15) concluem que há semelhanças nos modelos adotados:

[...] verificou-se que se caminha, no atual contexto federativo brasileiro, para um claro movimento geral de coordenação federal, que se expressa na criação de sistemas, planos ou programas nacionais com incentivos à adesão dos entes subnacionais, combinada à exigência de contrapartidas a serem cumpridas por parte desses entes, como a institucionalização de conselhos e fundos, por exemplo, e o atendimento a padrões de execução das políticas. As políticas atualmente apresentam em comum a lógica da transferência de recursos, muitas vezes fundo a fundo, da regulamentação federal de padrões e definição de competências, da adesão voluntária, e da previsão de sistemas de informação e de monitoramento e avaliação que permitem coordenação federal.

Nesse contexto de criação de sistemas de políticas públicas, surge o da habitação de interesse social - o SNHIS, por meio da lei $\mathrm{n}^{\mathrm{o}}$ 11.124/2005.

\footnotetext{
${ }^{32}$ A palavra sistema é empregada com diferentes significados. Mesmo no âmbito da Constituição Federal não há padronização no uso da palavra. Desse modo, vão ser apresentados apenas alguns sistemas criados em alguns setores de políticas públicas, não esgotando todos os sistemas existentes na legislação brasileira.

${ }^{33}$ Esse sistema foi criado pela lei $n^{\circ} 6.938 / 1981$, sendo anterior aos demais e até a Constituição Federal atual.
} 


\section{Capítulo 2: POLÍTICAS PÚBLICAS DE HABITAÇÃO NO BRASIL}

\section{Aspectos do direito à moradia}

O direito à moradia, incluído na Constituição de 1988 pela Emenda Constitucional n ${ }^{\circ}$ 26/2000, não se restringe à competência comum da União, dos Estados, dos Municípios e do Distrito Federal para construção e melhoria das condições habitacionais estabelecida pelo art. 23 da Constituição Federal.

Tal direito se relaciona, diretamente, com a competência concorrente de Estados, Distrito Federal e União para legislar sobre direito urbanístico (art. 24), com a competência comum de combater as causas da pobreza e os fatores de marginalização, promovendo a integração social dos setores desfavorecidos (art. 23, X), com a competência da União para instituir diretrizes para o desenvolvimento urbano (art. 21, XX) e para legislar privativamente sobre direito civil e agrário (art. 22, I), com a competência dos Estados para a criação de regiões metropolitanas, aglomerações urbanas e microrregiões por agrupamento de Municípios limítrofes para integrar a organização, o planejamento e a execução de funções públicas de interesse comum (art. $25, \S 3^{\circ}$ ) e, especialmente, a competência dos Municípios para a promoção do adequado ordenamento territorial com planejamento e controle do uso, do parcelamento e da ocupação do solo urbano (art. 30, VIII) e para a elaboração do plano diretor (art. $182, \S 1^{\circ}$ ), instrumento básico da política de desenvolvimento e de expansão urbanos, que também define o cumprimento da função social da propriedade urbana (art. 182, § $2^{\circ}$ ). Além disso, algumas leis e regulamentos organizam as tarefas dos entes federados na questão habitacional, como a lei $\mathrm{n}^{\mathrm{o}}$ 12.608/2012, que dispõe sobre o Sistema Nacional de Proteção e Defesa Civil.

O artigo 182 da Constituição Federal trata de uma perspectiva mais ampla de garantia da função social da cidade como objetivo da política de desenvolvimento urbano; o Estatuto da Cidade (lei $\mathrm{n}^{\circ}$ 10.257/2001) aborda o direito a cidades sustentáveis. Na Carta Mundial pelo Direito à Cidade, o direito à cidade é definido como o "usufruto equitativo das cidades dentro dos princípios de sustentabilidade, democracia e justiça social [...] O Direito à Cidade é interdependente a todos os direitos humanos internacionalmente 
reconhecidos, concebidos integralmente e inclui os direitos civis, políticos, econômicos, sociais, culturais e ambientais."

De acordo com a Declaração de Istambul para Assentamentos Humanos, produto da Conferência de 1996 que teve a participação de 171 países, inclusive o Brasil, a definição de moradia adequada integra diversos outros direitos (UN-HABITAT, 1996):

Moradia adequada significa mais que um teto sobre a cabeça. Também significa privacidade adequada; espaço adequado, acessibilidade física; segurança adequada; segurança da posse; estabilidade estrutural e durabilidade; iluminação adequada, aquecimento e ventilação; infra-estrutura básica adequada, tais como fornecimento de água, saneamento básico e de gestão de resíduos; qualidade ambiental adequada e de fatores relacionados à saúde; e localização adequada com acesso ao trabalho e as instalações básicas: todos os quais devem estar disponíveis a um custo acessível. Adequação deve ser determinada com as pessoas interessadas, considerando-se a perspectiva de um desenvolvimento gradual. Adequação frequentemente varia de país para país, já que depende de fatores culturais, sociais, ambientais e econômicos específicos. Fatores específicos de gênero e idade, tais como a exposição de crianças e mulheres a substâncias tóxicas, devem ser consideradas no contexto. ${ }^{34}$

Segundo o comentário geral $\mathrm{n}^{\circ} 04$ do Comitê dos Direitos Econômicos, Sociais e Culturais (UN, 1991), a habitação adequada inclui: a segurança jurídica da posse; a disponibilidade de serviços, materiais, instalações e infraestrutura; a adequação cultural; o custo acessível - não comprometimento de outras necessidades por causa dos gastos com moradia; a habitabilidade - espaço adequado para proteção contra frio, calor, vetores de doenças, entre outros; a acessibilidade física, localização que permita acessar opções de emprego, serviços de saúde, escolhas e outros serviços; e distância de fontes de poluição.

O mesmo documento aborda a relação do direito à moradia com outros direitos humanos (UN, 1991):

Como mencionado acima, o direito à moradia adequada não pode ser visto isoladamente de outros direitos humanos contidos nos dois Pactos Internacionais e outros instrumentos internacionais aplicáveis. [...] Além disso, o pleno

\footnotetext{
${ }^{34}$ Tradução livre de: "Adequate shelter means more than a roof over one's head. It also means adequate privacy; adequate space; physical accessibility; adequate security; security of tenure; structural stability and durability; adequate lighting, heating and ventilation; adequate basic infrastructure, such as water-supply, sanitation and waste-management facilities; suitable environmental quality and health-related factors; and adequate and accessible location with regard to work and basic facilities: all of which should be available at an affordable cost. Adequacy should be determined together with the people concerned, bearing in mind the prospect for gradual development. Adequacy often varies from country to country, since it depends on specific cultural, social, environmental and economic factors. Gender-specific and age-specific factors, such as the exposure of children and women to toxic substances, should be considered in this context."
} 
exercício de outros direitos - como o direito à liberdade de expressão, o direito à liberdade de associação (tal como para os inquilinos e outros grupos de base comunitária), o direito à liberdade de residência e o direito de participar na tomada de decisão pública - é indispensável se o direito à moradia adequada for realizado e mantido por todos os grupos sociais. Da mesma forma, o direito de não ser submetido a interferências arbitrárias ou ilegais na sua vida privada, família, domicílio ou correspondência constitui uma dimensão muito importante na definição do direito à moradia adequada. ${ }^{35}$

Esse conceito amplo de moradia digna inclui a relação da política habitacional com diversos outros setores, como as políticas públicas de saúde, ambientais, de saneamento, de transporte, de emprego e renda, econômicas, bem como sua relação com o ambiente construído da cidade, conforme observa Sérgio Azevedo (2007, p. 14):

Em função da interdependência da questão da moradia com outras esferas recorrentes e complementares, nem sempre um simples incremento dos programas de habitação se apresenta como a solução mais indicada para melhorar as condições habitacionais da população mais pobre. Em primeiro lugar, porque esses programas podem ser inviabilizados caso outras políticas urbanas, como as de transporte, de energia elétrica, de esgotamento sanitário e de abastecimento de água, não estejam integradas. Em segundo lugar, porque em certas ocasiões, em função do trade-off entre diversas políticas públicas, mudanças em outros setores - como maior investimento em saneamento básico (esgoto e água), incremento no nível de emprego, aumento do salário mínimo, regularização fundiária, entre outras - podem ter um impacto muito maior nas condições habitacionais das famílias de baixa renda do que um simples reforço dos investimentos no setor.

A política habitacional é extremamente ligada à política urbana, constitucionalmente de competência municipal. A construção de conjuntos habitacionais desvinculados da malha urbana e sem acesso a saneamento ou transporte é uma das consequências da falta de coordenação entre o planejamento do território e o planejamento das políticas públicas. É claro que essa descoordenação não é apenas fruto do arranjo

\footnotetext{
${ }^{35}$ Tradução livre de: "As noted above, the right to adequate housing cannot be viewed in isolation from other human rights contained in the two International Covenants and other applicable international instruments. [...]. In addition, the full enjoyment of other rights - such as the right to freedom of expression, the right to freedom of association (such as for tenants and other community-based groups), the right to freedom of residence and the right to participate in public decision-making - is indispensable if the right to adequate housing is to be realized and maintained by all groups in society. Similarly, the right not to be subjected to arbitrary or unlawful interference with one's privacy, family, home or correspondence constitutes a very important dimension in defining the right to adequate housing."
} 
federativo, mas a autonomia dos entes torna as políticas ainda mais complexas, especialmente as de competência comum.

Além das competências já mencionadas, a ligação da política habitacional atual com o financiamento dá relevância às políticas econômicas, que são concentradas no governo central, como a fiscalização de operações de crédito e a competência privativa legislativa sobre política de crédito e sistemas de poupança. Conforme Adauto Cardoso et al. (2013, p. 46):

Nesse sentido, se consideramos, com Ribeiro (1997) que a questão da moradia passa pelo enfrentamento do problema do financiamento e do problema da terra, o modelo institucional pós-Constituição deixa uma destas dimensões (a terra) na esfera municipal e outra (o financiamento) na esfera federal.

Outro aspecto dessa interdependência entre diversos direitos e políticas se mostra na situação de exclusão territorial realimentando a exclusão social, como salienta Raquel Rolnik (2006, p. 200):

A presença desse vasto contingente de assentamentos inseridos de forma ambígua na cidade é uma das mais poderosas engrenagens da máquina de exclusão territorial que bloqueia o acesso dos mais pobres às oportunidades econômicas e de desenvolvimento humano que as cidades oferecem. Essa situação de exclusão é muito mais do que a expressão das desigualdades sociais e de renda: ela é agente de reprodução dessa desigualdade. Em uma cidade dividida entre a porção legal, rica e com infra-estrutura, e a ilegal, pobre e precária, a população que está em situação desfavorável acaba tendo muito pouco acesso a oportunidades de trabalho, cultura e lazer. Simetricamente, as oportunidades de crescimento circulam no meio daqueles que vivem melhor, pois a sobreposição das diversas dimensões da exclusão incidindo sobre a mesma população fazem com que a permeabilidade entre as duas partes seja muito pequena.

Trata-se, portanto, de um conjunto complexo de competências legislativas e administrativas que se relacionam, cabendo diversos papéis a cada ente federado. Por essa composição complexa, a coordenação institucional na formulação e implementação das políticas públicas de moradia é essencial para sua efetividade.

\section{A questão habitacional no Brasil}

A moradia adequada pode ter diversas acepções, dependendo de quem avalia, qual a situação econômica do país que avalia, quais interesses se encontram por trás dessa 
avaliação, qual método foi utilizado. Por isso, é extremamente difícil encontrar um indicador seguro que consiga representar sinteticamente o problema habitacional do país.

O primeiro indicador que podemos mencionar é o da Fundação João Pinheiro (FJP), um dos mais utilizados e conhecidos no campo habitacional. A FJP calcula os índices de déficit e inadequação habitacional: o déficit habitacional inclui domicílios rústicos ${ }^{36}$, ônus

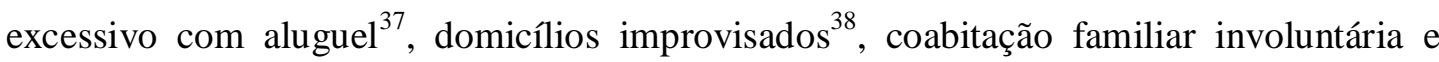
adensamento excessivo de apartamentos e casas alugadas (MCIDADES, 2009a, p. 17); os domicílios inadequados (MCIDADES, 2009a, p. 19) são aqueles "com carência de infraestrutura $^{39}$, com adensamento excessivo de moradores ${ }^{40}$, com problemas de natureza fundiária $^{41}$, com cobertura inadequada ${ }^{42}$, sem unidade sanitária domiciliar exclusiva ou em alto grau de depreciação." 43

Segundo esse estudo (MCIDADES, 2009a, p. 24.):

O déficit habitacional estimado em 2007 é de 6,273 milhões de domicílios, dos quais 5,180 milhões, ou 82,6\%, estão localizados nas áreas urbanas. Relativamente, corresponde a $11,1 \%$ do estoque de domicílios particulares permanentes do país, sendo $10,8 \%$ nas áreas urbanas e 12,9\% nas rurais.

\footnotetext{
${ }^{36}$ Domicílios rústicos são aqueles sem paredes de alvenaria ou madeira aparelhada.

${ }^{37}$ Ônus excessivo com aluguel corresponde às famílias com renda familiar de até três salários mínimos que despendem mais de $30 \%$ de sua renda com aluguel.
}

${ }^{38}$ Locais construídos sem fins residenciais que servem como moradia, tais como barracas, viadutos, prédios em construção, carros, etc.

${ }^{39}$ São considerados domicílios carentes de infraestrutura todos os que não dispõem de ao menos um dos seguintes serviços básicos: iluminação elétrica, rede geral de abastecimento de água com canalização interna, rede geral de esgotamento sanitário ou fossa séptica e coleta de lixo.

${ }^{40}$ Adensamento excessivo de domicílios: mais de três moradores por dormitório. Apenas domicílios próprios, os alugados estão no déficit.

${ }^{41} \mathrm{~A}$ inadequação fundiária refere-se aos casos em que pelo menos um dos moradores do domicílio tem a propriedade da moradia, mas não, total ou parcialmente, do terreno ou da fração ideal de terreno (no caso de apartamento) em que ela se localiza. Cabe observar a crítica ao subdimensionamento desse indicador, decorrente da declaração do próprio morador: "Os dados sobre irregularidade fundiária das moradias são coletados por meio de declarações dos próprios moradores. Porém, não há, por parte desses moradores, compreensão precisa e clara sobre as condições adequadas de titulação e registro da propriedade do terreno onde moram. E, no presente momento, o IBGE não tem como buscar esse dado junto a fontes institucionais." BRASIL. Via Pública; Lab hab-Fupam; Logos Engenharia. Plano Nacional de Habitação: Contextualização do Plano Nacional de Habitação. Produto 2, vol. I, 2007, p. 114.

${ }^{42}$ Sob cobertura inadequada estão incluídos todos os domicílios que, embora possuam paredes de alvenaria ou madeira aparelhada, tenham telhado de madeira aproveitada, zinco, lata ou palha.

${ }^{43}$ As inadequações podem ser sobrepostas e por isso não podem ser somadas. 
A coabitação familiar é o fator com maior peso no déficit, a não ser na região sudeste onde o ônus excessivo com aluguel representa 51,1\% do total (MCIDADES, 2009a, p. 38.): "No Brasil, a coabitação familiar representa 39,3\% do déficit, o ônus excessivo com aluguel, $32,2 \%$, as habitações precárias, $23 \%$, e o adensamento excessivo dos domicílios alugados, 5,5\%."

O estudo dividiu a população em faixas de renda por salários mínimos: zero a três, mais de três a cinco, mais de cinco a dez e mais de dez, constatando a concentração na população mais pobre (MCIDADES, 2009a, p. 28) "é confirmada a concentração do déficit na faixa até três salários mínimos: $89,4 \%$. Ao se considerar a faixa de renda imediatamente superior são mais 6,5\% das famílias, totalizando 95,9\% das carências urbanas."

A Caixa Econômica Federal (CEF, 2011) divulgou estudo em que calcula as demandas habitacionais de maneira distinta, criando dois indicadores: Demanda Habitacional Domiciliar (DHDO) - inclui domicílios improvisados, cômodos e domicílios que não tem banheiro ou vaso sanitário - e Demanda Habitacional Demográfica (DHDE) que "Capta, pela estrutura demográfica, as possibilidades de surgimento de novos chefes de família, pois calcula o número de pessoas adultas no domicílio (além do responsável e cônjuge), ponderadas pela taxa de chefia do respectivo grupo etário.” (CEF, 2011, p. 28). Segundo esse método (CEF, 2011, p. 29): “[...] em valores absolutos a Demanda Habitacional Total (DHDE+DHDO) no Brasil, em 2009, é estimada em 9.297.214 de domicílios. Entretanto, observada em relação aos 58.646 .432 de domicílios existentes no mesmo período, a proporção equivale a Demanda Relativa de 15,85\%."

Ou seja, por causa da metodologia diferente, o cálculo do déficit pela FJP somou 6,273 milhões de unidades em 2007 e a demanda habitacional da Caixa em 2009 foi de 9,297 milhões de unidades.

O Sinduscon-SP (2010), que representa as Empresas da Construção Civil do Estado, e a FGV têm lançado periodicamente um estudo do déficit com outro método, tendo, em 2009, atingido o número de 5,8 milhões de famílias ou 9,3\% do total. A maior crítica ao método é a inclusão de moradias em favelas no déficit e não na inadequação domiciliar, conforme abordam Sergio de Azevedo e Maria Bernadette Araujo (2007, p. 248):

Na nossa avaliação, a limitação da metodologia FGV/Sinduscon, comparada com a da FJP, não se deve a questões de ordem técnica ou estreiteza acadêmica. Trata-se de um viés profissional voltado para maximizar os interesses do 
Sinduscon. Mais do que priorizar, ele reduz a questão da habitação popular exclusivamente à necessidade de construção de novas residências.

O Estado de São Paulo (2010) também empregou um método diferente para o cálculo de necessidades habitacionais, utilizando a Pesquisa de Condições de Vida, realizada em 2006 pela Fundação Seade, como base de dados para o cálculo. Na definição paulista, o déficit inclui barraco isolado ou em favela, moradia localizada em área de risco de desmoronamento e moradia invadida localizada em área de risco de enchente, sem pavimentação, guias e sarjetas; já a inadequação é composta de: moradia de alvenaria localizada em favela, moradia localizada em cortiço, moradia com espaço interno insuficiente $^{44}$, moradia com congestionamento domiciliar ${ }^{45}$, moradia com infraestrutura interna insuficiente ${ }^{46}$, moradia própria sem documentação de posse $\mathrm{e}^{47}$ e moradia alugada com renda domiciliar inferior a três salários mínimos.

Segundo essa metodologia, para o Estado de São Paulo (2010, p. 16) “[...] as necessidade habitacionais no Estado de São Paulo totalizam 3.901 mil domicílios, que equivalem a 32,6\% do estoque existente em 2006. A maior parcela é de domicílios inadequados (3.236mil) e o déficit é de 665mil domicílios.” Já segundo a FJP (MCIDADES, 2009a, p. 25), em 2007, o déficit em São Paulo seria de 1.234.306 domicílios.

O IBGE (2010b, p. 38) investigou, durante o censo, os aglomerados subnormais ${ }^{48}$ : "Em 2010, 6\% da população do País (11.425.644 pessoas) morava em aglomerados subnormais, distribuída em 3.224.529 domicílios particulares ocupados (5,6\% do Brasil)." Nesse caso, o método também é relevante, já que o IBGE considera somente os aglomerados acima de 50 unidades habitacionais, o que pode subdimensionar a quantidade.

\footnotetext{
${ }^{44}$ Habitação que não dispõe de cômodos que atendam às funções básicas de repouso, lazer, preparo de alimentos e higiene.

${ }^{45}$ Mais de uma pessoa por cômodo, ou mais de duas pessoas por dormitório, ou onde a sala ou a cozinha é utilizada como dormitório.

${ }^{46}$ Não dispõe do acesso simultâneo às redes de abastecimento de água, energia elétrica, esgotamento sanitário e coleta de lixo.

${ }^{47}$ Habitação em que o morador declarou não dispor de documento de posse do imóvel.

${ }^{48}$ Segundo o IBGE, Aglomerado subnormal: "É um conjunto constituído de, no mínimo, 51 unidades habitacionais (barracos, casas, etc.) carentes, em sua maioria de serviços públicos essenciais, ocupando ou tendo ocupado, até período recente, terreno de propriedade alheia (pública ou particular) e estando dispostas, em geral, de forma desordenada e densa." BRASIL. Ministério do Planejamento, Orçamento e Gestão. Instituto Brasileiro de Geografia e Estatística - IBGE. Censo Demográfico 2010: Aglomerados subnormais Primeiros resultados. Rio de Janeiro, 2010, p. 19.
} 
Segundo esse estudo (IBGE, 2010b, p. 40), a presença de aglomerados subnormais é concentrada em regiões populosas, como as Regiões Metropolitanas com mais de 1.000.000 de habitantes: "88,2\% dos domicílios em aglomerados subnormais estavam em Regiões Metropolitanas com mais de 1 milhão de habitantes e apenas 11,8\% destes domicílios estavam em Municípios isolados ou Regiões Metropolitanas com menos de 1 milhão de habitantes.” Segundo dados do Censo (2010b, p. 39), no Brasil: “[...] foram identificados 6.329 aglomerados subnormais em 323 municípios", a "Região Sudeste agrupava quase a metade dos municípios do País com aglomerados (145 municípios), sendo um pouco mais da metade nas Regiões Metropolitanas (75 municípios) e o restante em municípios do interior dos estados."

Outra dificuldade de mensuração do problema se relaciona à falta de informações acerca das pessoas em situação de rua. Algumas iniciativas têm sido tomadas em algumas localidades $^{49}$ e houve uma pesquisa de âmbito nacional ${ }^{50}$, ainda que por amostragem. Mas, de maneira geral, essas pessoas não são contabilizadas pelas pesquisas periódicas.

Além dessa complexidade na mensuração do problema, a questão habitacional apresenta uma distribuição desigual em relação a outros indicadores sociais. Apesar de a região Sudeste apresentar o segundo menor valor relativo - déficit em relação ao estoque de domicílios particulares permanentes $-9,3 \%$, por sua grande população, há concentração do déficit em números absolutos. Desse modo, os quatro Estados da região contabilizam um déficit de 2.335.415 moradias, 37,2\% do total do país, sendo que faltam 628.624 unidades apenas na região metropolitana de São Paulo.

Outra região com enorme concentração do déficit é o nordeste: correspondente a 15\% dos domicílios, o equivalente a 2.144.384 de unidades. Desse modo, as duas regiões Sudeste e Nordeste concentram $71,4 \%$ do déficit do país.

Cabe observar que acabar com o déficit habitacional envolve estratégias distintas, de acordo com especificidades locais, já que mesmo as regiões que concentram o PIB, a renda e os melhores indicadores sociais do país, como o Sudeste, podem ter enormes problemas em prover moradia digna à população, especialmente à de baixa renda. A

\footnotetext{
${ }^{49}$ Em São Paulo, por exemplo, foram realizadas duas pesquisas sobre a população em situação de rua: em 2008/2009 e em 2011/2012. Disponível em: http://www.prefeitura.sp.gov.br/cidade/secretarias/assistencia_social/observatorio_social/pesquisas/index.php ?p=18626>. Acesso em 25.08.2013.

${ }^{50}$ Primeiro censo e pesquisa nacional sobre a população em situação de rua. Resultados disponíveis em: < http://www.mds.gov.br/backup/arquivos/sumario_executivo_pop_rua.pdf >. Acesso em 25.08.2013.
} 
relação entre o $\mathrm{IFDM}^{51}$ (indicador sintético que considera indicadores de emprego, renda, educação e saúde) e o déficit absoluto e relativo pode ser observada na tabela a seguir:

\begin{tabular}{|c|c|c|c|}
\hline & $\begin{array}{l}\text { IFDM } 2007 \\
\text { (crescente) }\end{array}$ & $\begin{array}{c}\text { Déficit Absoluto } \\
2007\end{array}$ & $\begin{array}{c}\text { Déficit Relativo } \\
2007\end{array}$ \\
\hline $\mathrm{AL}$ & 0,5529 & 123.245 & $14,8 \%$ \\
\hline $\mathrm{AP}$ & 0,5740 & 30.449 & $20,2 \%$ \\
\hline MA & 0,5900 & 461.396 & $29,5 \%$ \\
\hline PI & 0,5961 & 139.318 & $16,9 \%$ \\
\hline $\mathrm{PA}$ & 0,5974 & 317.089 & $17,1 \%$ \\
\hline PB & 0,6010 & 122.166 & $12,2 \%$ \\
\hline $\mathrm{AC}$ & 0,6087 & 21.063 & $12,6 \%$ \\
\hline BA & 0,6093 & 510.677 & $12,9 \%$ \\
\hline $\mathrm{RO}$ & 0,6117 & 52.472 & $11,6 \%$ \\
\hline $\mathrm{AM}$ & 0,6169 & 146.268 & $18,6 \%$ \\
\hline RR & 0,6265 & 16.379 & $14,7 \%$ \\
\hline $\mathrm{SE}$ & 0,6289 & 73.499 & $13,0 \%$ \\
\hline $\mathrm{TO}$ & 0,6445 & 68.964 & $18,2 \%$ \\
\hline $\mathrm{PE}$ & 0,6467 & 281.486 & $11,7 \%$ \\
\hline $\mathrm{CE}$ & 0,6511 & 314.949 & $13,9 \%$ \\
\hline $\mathrm{RN}$ & 0,6547 & 117.647 & $14,0 \%$ \\
\hline MT & 0,6787 & 86.679 & $9,8 \%$ \\
\hline MS & 0,6988 & 76.027 & $10,5 \%$ \\
\hline $\mathrm{GO}$ & 0,7141 & 167.042 & $9,2 \%$ \\
\hline $\mathrm{DF}$ & 0,7368 & 107.248 & $14,6 \%$ \\
\hline $\mathrm{ES}$ & 0,7499 & 101.124 & $9,4 \%$ \\
\hline $\mathrm{RS}$ & 0,7586 & 285.261 & $7,8 \%$ \\
\hline $\mathrm{MG}$ & 0,7846 & 521.085 & $8,8 \%$ \\
\hline $\mathrm{SC}$ & 0,7938 & 145.363 & $7,6 \%$ \\
\hline RJ & 0,7985 & 478.901 & $9,1 \%$ \\
\hline PR & 0,8244 & 272.542 & $8,3 \%$ \\
\hline SP & 0,8697 & 1.234 .306 & $9,6 \%$ \\
\hline
\end{tabular}

Fonte: Ipeadata/Firjan; FJP/MCIDADES, 2009a.

É possível observar que os Estados com menor IFDM possuem maiores índices de déficit relativo em 2007, ou seja, é maior a porcentagem de domicílios a serem construídos em relação ao total já existente. No entanto, a participação dos cinco Estados com os

${ }^{51}$ O Índice Firjan de Desenvolvimento Municipal é calculado com base em estatísticas oficiais. Quanto mais próximo de 1, maior o desenvolvimento. Disponível em: 〈http://www.firjan.org.br/ifdm/ $\rangle$ e http://www.ipeadata.gov.br/. Acesso em 20.07.2012. 
melhores indicadores sociais em números absolutos, representa $42,3 \%$ do total para o país, ainda que tenham menor participação no total de domicílios respectivos. A questão habitacional deve também ser observada em regiões com bons indicadores sociais e econômicos, já que a população pobre destas regiões tem um peso bastante significativo na falta de moradia no país.

Outra questão sobre a mensuração do problema habitacional é a dificuldade em separar a melhoria das condições habitacionais decorrente das políticas habitacionais, de outros fatores como a melhoria da renda das famílias, observação feita pela Controladoria Geral da União (CGU) no relatório apresentado pelo Ministério das Cidades (CGU. SNH, 2010, p. 23):

A utilização de indicadores habitacionais macros não é totalmente adequada para se mensurar o impacto do programa visto que outros fatores influenciam a precariedade habitacional, tais como disponibilidade de crédito e produção habitacional, associadas a outros programas - e, até conjuntura econômica. Ou seja, não há como isolar 1 único fator - investimento em urbanização e informar que essa é a causa do decréscimo do déficit; há de se olhar a Política Nacional de habitação de forma integral.

Uma característica que dificulta a formulação e a implementação de políticas habitacionais é a dificuldade em entender a habitação como um serviço público. Enquanto algumas políticas como a educação e a saúde foram sendo universalizadas de forma gratuita à população, a mesma estratégia não é utilizada para as políticas de habitação: em sua maioria, os programas habitacionais são baseados em financiamento habitacional, subsídios e construção terceirizada dos imóveis. Isso pode ser relacionado com a ideologia da casa própria e aos maiores benefícios e segurança que a legislação e a sociedade concedem ao proprietário diante de outros posseiros, como os locatários ou moradores de áreas concedidas pelo poder público.

Atualmente, há um projeto de lei que visa à criação de um Serviço de Moradia Social no âmbito do SNHIS, nos moldes dos demais serviços públicos (art. $2^{\circ}$ do projeto de lei $n^{\circ}$ 6.342/2009): "Serviço de Moradia Social é o serviço público gratuito que visa garantir moradia digna para a população de baixa renda, por meio de um conjunto de ações e iniciativas integradas com as demais políticas de desenvolvimento urbano e promoção social, de forma participativa, continuada e articulada entre os entes federativos e organizações da sociedade civil.” O modelo é uma espécie de aluguel fornecido pelo Poder Público em seus bens ou em bens privados utilizados para essa finalidade; o pagamento seria feito pelo Estado em áreas providas de infraestrutura, constituindo em uma via 
alternativa de política habitacional com a utilização prioritária de imóveis públicos subutilizados. 52

Por último, cabe a reflexão de Friedrich Engels (1982) acerca da questão da falsidade de um 'déficit' de habitações: “É, porém, certo que já hoje existem nas grandes cidades edifícios suficientes para, com uma utilização racional dos mesmos, se remediar de imediato toda a «falta de habitação» real."

\section{Breve histórico da política habitacional no Brasil}

A relevância de se realizar um pequeno histórico da política habitacional no país se relaciona com a permanência de certas práticas, estruturas organizacionais e modelos de intervenção estatal, o que auxilia na explicação sobre o funcionamento das políticas públicas atuais. Será dado destaque à estrutura dos órgãos públicos na política habitacional ao longo do tempo e as relações entre os entes federados, bem como às políticas de âmbito nacional.

A questão da moradia passou muito tempo sem ser reconhecida como um problema, conforme observa Flávio Villaça (s.d., p. 4):

Nem o Reino de Portugal nem o Império do Brasil em seus primórdios, jamais reconheceram e muito menos assumiram esse problema. Também a sociedade civil não o colocou ao Estado, nem tampouco a classe dirigente reconheceu-o como seu. Tudo isso simplesmente porque o problema não existia.

No século XIX, a questão habitacional e a intervenção urbana, segundo Alberto Najar e Eduardo Marques (2003), teve alguma importância por influência de questões de saúde pública. A falta de higiene, o compartilhamento de espaços por diversas famílias e a inadequação das habitações é o primeiro aspecto da habitação tratado pelo Estado, sempre de um ponto de vista repressivo em favor da ordem sanitária, como aborda Nabil Bonduki (2002). Houve incentivos à iniciativa privada na construção de moradias, especialmente vilas operárias, agindo o Estado de maneira bastante esparsa e limitada.

Cabe observar que no Rio de Janeiro, ainda na Primeira República, o Presidente Hermes da Fonseca construiu vilas no "[...] que pode ser reconhecido como a primeira intervenção federal na questão da habitação no Brasil.” (Nelson da N. Fernandes e Alfredo C. T. de Oliveira, 2010). O presidente criou também, em 1910, a Comissão de Construção

\footnotetext{
${ }^{52} \mathrm{O}$ projeto segue em tramitação no Congresso Nacional.
} 
das Vilas Proletárias, tendo projetado outros dois conjuntos de residências inconclusos total e parcialmente.

No período varguista, a questão habitacional foi colocada como problema também para o Estado, conforme aponta Bonduki (2002, p. 73):

[...] num quadro em que todas as questões econômicas tornaram-se preocupação do poder público e das entidades empresariais envolvidas na estratégia de desenvolvimento nacional, o problema da moradia emergiu como aspecto crucial das condições de vida do operariado, pois absorvia porcentagem significativa dos salários e influía no modo de vida e na formação ideológica dos trabalhadores.

O incentivo foi direcionado para a casa unifamiliar de periferia, escolhida em detrimento dos cortiços multifamiliares do centro, porque permitia segregar as classes, difundir a propriedade privada e evitar a contaminação dos trabalhadores com discursos socialistas; escolha também defendida pela igreja, preocupada com a promiscuidade nas habitações coletivas. A época contou também com um congelamento dos aluguéis, que acabou diminuindo a oferta de imóveis para locação por reduzir a atratividade desse investimento.

\subsection{Institutos de Aposentadoria e Pensão}

A política habitacional a partir da década de 1930 foi executada pelos Institutos de Aposentadoria e Pensão (IAPs), que sempre tiveram uma atuação ambígua na questão habitacional: sendo instituições previdenciárias, a capitalização emergia como objetivo mais importante do que a provisão de moradias para os trabalhadores de baixa renda. Os institutos eram formados por categoria profissional, organizados por legislações diferentes, discriminando trabalhadores informais e até trabalhadores formais ligados a institutos com menos recursos (Marcus André B. C. de MELO, 1990, p. 4):

A opção pela aplicação dos recursos dos IAPs em habitação, apesar de prevista em 1932, só adquire expressão em 1937, na gestão de Agamenon Magalhães à frente do Ministério do Trabalho, que conferiu forte prioridade à questão da habitação. Durante o Estado Novo se deu início à construção de grandes conjuntos residenciais, ao mesmo tempo em que se avolumavam vertiginosamente as reservas dos IAPs, que passam a ser canalizadas para o crédito imobiliário, como já foi mencionado anteriormente. Nos últimos anos do Estado Novo, a crise de habitação se agudizou, contrastando fortemente com o surto imobiliário impulsionado, em parte, pelos recursos dos IAPs. Apesar da censura e controle da opinião pública, a questão se politiza, instalando um 
conflito dentro do aparelho de Estado, solapando a legitimidade que a política social desfrutava junto aos setores populares.

Tendo em vista a baixa rentabilidade da aplicação de recursos em habitação de interesse social para a preservação de seu patrimônio e das futuras aposentadorias, passouse a investir mais em moradias para a classe média. Apesar dessas limitações, as construções dos planos A e B - para a população mais pobre - somaram 124.025 unidades (BONDUKI, 1994).

\subsection{Fundação Casa Popular}

A Fundação da Casa Popular (FCP) foi criada pelo decreto-lei nº 9.218/1946, conforme aborda Melo (1990, p. 39):

[...] a criação da Fundação da Casa Popular (FCP) se constituiu um desdobramento histórico e uma resposta do Estado à forte crise nacional de habitação, que atingiu sobretudo o antigo Distrito Federal (Rio de Janeiro), à descoberta e politização da questão urbana expressa num discurso novo sobre as favelas e mocambos e ao processo institucional interno ao Ministério do Trabalho, que culminaria na unificação dos diversos Institutos de Aposentadoria e Pensões (IAPs) e, conseqüentemente, das suas carteiras prediais, abrindo então a possibilidade de uma política nacional de habitação.

Apesar de prevista no anteprojeto da FCP, a unificação das carteiras dos IAPs só ocorreria com a criação do Banco Nacional da Habitação (BNH).

No decreto-lei no 9.777/1946, há a previsão de cooperação técnica para pequenos Municípios sem recursos humanos qualificados e o financiamento de construções sob a responsabilidade das prefeituras. A articulação da fundação com os governos locais representou uma das fragilidades de sua atuação, conforme observa Melo (1990, p. 52):

No que se refere ao seu padrão de atuação, a FCP foi levada a se envolver no labirinto da política local, em várias regiões do país. Os projetos dos conjuntos eram realizados na sede da FCP, na ignorância confessada das especificidades

locais, e os mínimos detalhes técnicos, concorrências locais, etc. mereciam pareceres do conselho técnico do órgão. Paulatinamente, como já foi referido, a FCP se restringe a referenciar os pedidos das prefeituras a partir de uma perspectiva clientelística. A disponibilidade de terrenos e o comprometimento da prefeitura em arcar com as obras de urbanização converteram-se em fatores importantes na escolha das cidades a serem contempladas.

A fundação lidou com diversas limitações, especialmente no seu financiamento, ligado a um imposto de transações imobiliárias que nunca foi cobrado devidamente, sofreu 
boicote por alguns Estados (inclusive com a abstenção deles em cobrar o imposto), além da pressão do setor da construção civil, preocupado com a escassez de materiais e de crédito.

Grupos internos e externos à burocracia estatal que não desejavam o enfraquecimento dos institutos e a descentralização das decisões sobre financiamentos, realizadas pelo Conselho Nacional do Trabalho e pelo Departamento Nacional da Previdência Social, contribuíram como um dos fatores de sua atuação limitada (VILLAÇA, p. 25): "A Fundação foi extinta em 1964 e em toda sua existência não produziu mais que 16.100 unidades."

De todo modo, a FCP foi o primeiro órgão de âmbito nacional destinado à temática da habitação. Nesse período, já havia problemas de coordenação e operacionalização que se seguiriam no setor pelas décadas seguintes.

\subsection{Banco Nacional da Habitação}

Na ditadura militar, por meio da lei $\mathrm{n}^{\circ}$ 4.380/1964, foi criado o Banco Nacional da Habitação (BNH), que foi uma política do governo central, executada com algum grau de autonomia pelos entes subnacionais, por meio da contratação de empresas privadas (ARRETCHE, 2000, p. 80):

O modelo de intervenção pública inaugurado pelo BNH estava assentado sobre a existência de uma agência federal da qual emanavam os recursos e as políticas a serem implementadas no território nacional. Para implementar os programas habitacionais de interesse social, este designava agentes promotores, de âmbito municipal, intermunicipal ou estadual. Tais agências desempenhavam as funções de promoção imobiliária, ocupando um espaço de gerenciamento do processo produtivo (financiamento, promoção e comercialização), restando o processo de edificação propriamente dito para empreiteiras privadas, contratadas para esta finalidade mediante licitações.

A política era baseada na provisão de 'casa própria' para o trabalhador, modelo já criticado por David Harvey (1982, pp. 8-9): “A promoção da casa própria para os trabalhadores estabelece a submissão destes ao princípio da propriedade privada". O mesmo padrão se mostrou bastante frequente em diversos países (NACIONES UNIDAS, 2012, p. 4): Apesar da relativa diversidade de experiências sobre as políticas de habitação, a maioria dos países optou por promover os mercados imobiliários e a propriedade 
individual, privatizar os programas de moradia social e desregular os mercados de financiamento da habitação. ${ }^{53}$

O modelo se estendeu por décadas na política de habitação (ARRETCHE, 1998, p. 107): "Até meados dos anos 80, a oferta pública de habitações no Brasil se deu sob o sistema estruturado nos anos 60, vale dizer, sob o conjunto de mecanismos institucionais, administrativos e financeiros articulados pelo BNH."

A estratégia utilizada pelo Banco beneficiou o setor da construção civil, que pôde contar com uma fonte de financiamento estável, mas não contribuiu significativamente para a melhoria das condições habitacionais da população de baixa renda no país. É a conclusão de Gabriel Bolaffi (1979, p. 47), já na década de 70:

Tudo indica, portanto, que o "problema da habitação popular", formulado há mais dez anos e até agora não resolvido - e, como veremos mais adiante, consideravelmente agravado -, apesar dos fartos recursos que supostamente foram destinados para a solução, não passou de um artifício político formulado para enfrentar um problema econômico conjuntural.

Segundo pondera Nabil Bonduki (2008, p. 73): "Malgrado as críticas ao BNH e ao sistema por ele preconizado, sua importância é indiscutível, pois este período (1964-86) foi o único em que o país teve, de fato, uma Política Nacional de Habitação." Uma das fraquezas da política apontada pelo autor foi o banco não ter dado relevância para as especificidades locais (BONDUKI, 2008, p. 74): "Indiferente à diversidade existente num país de dimensões continentais, o BNH desconsiderou as peculiaridades de cada região, não levando em conta aspectos culturais, ambientais e de contexto urbano, reproduzindo à exaustão modelos padronizados."

A lei do BNH também transformou a FCP em Serviço Federal de Habitação e Urbanismo (SERFHAU), que deveria ser o agente de articulação e planejamento urbano, mas acabou submisso ao banco. Entre outras limitações, essa submissão se dava nas decisões de financiamento dos planos de desenvolvimento local integrado, submetidas à diretoria do banco, nas normas de planejamento, nos seus projetos e na sua organização administrativa subordinados ao Conselho de Administração do BNH. Conforme menciona Geraldo Serra (1991, p. 61):

\footnotetext{
${ }^{53}$ Tradução livre de: "Pese a la relativa diversidad de experiencias en cuanto a las políticas de vivienda, la mayoría de los países optaron por promover los mercados inmobiliarios y la propiedad individual, privatizar los programas de vivienda sociales y desregular los mercados de financiación de la vivienda."
} 
Note-se que a preocupação central era com a questão da habitação, aparecendo o urbanismo apenas no nome do órgão técnico que supostamente deveria desenvolver estudos e pesquisas para o planejamento das ações do banco e do crescimento das cidades. [...] A diferença principal no enfoque dado pelo governo e na posição dos engenheiros e arquitetos, nas diversas reuniões e debates, era que o governo insistia em que a questão era fundamentalmente financeira, exigindo como remédio um instrumento adequado, isto é, um Banco, enquanto que os profissionais da área acreditavam que os aspectos técnicos deveriam também ser considerados. A impressão, quando da publicação do contexto final da lei, foi de que a criação do SERFHAU era uma cessão no sentido de atender às exigências técnicas.

Além disso, a transferência de recursos controlados pelo governo federal permitia a imposição de suas preferências (SERRA, 1991, p. 108):

O governo federal, para conceder um empréstimo - e não um recurso a fundo perdido -, com o dinheiro que não era seu mas do trabalhador, que teria de ser devolvido com juros e correção monetária e que estava garantido pela intermediação de um agente financeiro (intermediação pela qual também se devia pagar), impunha normas de racionalidade. O que subjaz é o pressuposto já anteriormente apontado de ser o dono da racionalidade o proprietário de um saber específico sobre como se deve e como não se deve promover o desenvolvimento urbano e, a partir daí, usando dinheiro que não era seu, impor condições de controle político ao prefeito.

A extinção do BNH aconteceu em 1986, quando o presidente Sarney passou a gestão do Fundo de Garantia do Tempo de Serviço (FGTS) para a Caixa Econômica Federal (CEF), que não estava preparada para semelhante função (ARRETCHE, 1998, p. 111):

Ora, a extinção do BNH e a desarticulação de sua burocracia, a 'via-crúcis' ministerial, o 'fiasco' dos esforços de reforma e a crise do FGTS levaram à progressiva ausência do governo federal no setor, no que se refere à sua capacidade tanto de manter os níveis de financiamento à promoção pública de habitações, quanto de formular e implementar uma política habitacional capaz de reorganizar a produção residencial pública no país.

É relevante destacar que, apesar de o BNH constituir um banco nacional e ter na sua lei de criação o objetivo de estimular a coordenação entre os órgãos públicos federais, estaduais, municipais e as iniciativas privadas (art. $3^{\circ}, \S 1^{\circ}$ da lei $n^{\circ} 4.380 / 64$ ), não havia grande articulação entre os entes ou entre as políticas desenvolvidas. Com sua extinção, houve um vazio institucional no governo central, que foi ocupado pelos entes subnacionais de maneira bastante heterogênea. 


\subsection{Pós-BNH}

A extinção do BNH se deu por meio do decreto-lei no 2.291/1986, que fez da CEF sua sucessora, inclusive quanto à gestão do FGTS, e destinou ao Conselho Monetário Nacional $(\mathrm{CMN})$ as atribuições do BNH como órgão central do Sistema Financeiro de Habitação (SFH).

O FGTS sofreu uma crise, resultado da diminuição da arrecadação, do aumento de saques, da má-gestão dos recursos e da corrupção, como aborda Arretche (1996, p. 112): "com uma arrecadação bruta diretamente dependente da massa salarial e tendo parte de seus recursos vinculados a compensar situações de risco no âmbito do mercado do trabalho, o FGTS foi inevitavelmente prejudicado pela recessão."

A questão habitacional foi atribuída a sucessivos ministérios, não sendo possível verificar uma política que tentasse trazer coerência aos programas habitacionais sendo desenvolvidos no país. Para Maria Hermínia Tavares de Almeida (1996, pp. 126-7) a habitação

[...] foi um caso exemplar de descentralização espontânea, ou por ausência: à medida que o Governo federal foi perdendo capacidade de ação, estados e municípios começaram a desenvolver políticas próprias assumindo de forma autônoma a responsabilidade por decisões sobre programas e por seu financiamento.

É o que Adauto Cardoso (2009, p. 4) denomina 'descentralização perversa' por aprofundar desigualdades:

$\mathrm{O}$ vazio institucional na esfera federal e a incapacidade financeira dos governos estaduais gerou um processo de descentralização perversa. Se, por um lado, observa-se que as administrações locais assumem, com maior vigor, a responsabilidade pelo desenvolvimento de uma política habitacional municipal, por outro lado, observa-se que as enormes desigualdades regional e intermunicipal manifestam-se através de um diferencial significativo na performance dos governos municipais, aprofundando portanto as desigualdades já existentes. Estes elementos mostram-se tanto na comparação entre municípios do Sudeste e do Norte-Nordeste, ou entre capital e interior, quanto entre municípios centrais e periféricos das Regiões Metropolitanas. Além das consequiências sobre as desigualdades sociais e interurbanas, este processo acirra a competição e o conflito federativo, contribuindo para um processo de fragmentação nacional e para a dificuldade, cada vez maior, de construção de um projeto nacional. 
O setor ficou com sua maior fonte de recursos ainda mais comprometida devido ao Governo Collor, como analisa Sérgio Azevedo (2007, p. 4):

A utilização predatória dos recursos do FGTS, que caracterizou os últimos 2 anos em que Collor esteve no poder, teve consequiências graves sobre as possibilidades de expansão do financiamento habitacional, levando à suspensão por dois anos de qualquer financiamento, no período subseqüente.

A capacidade de produção das companhias habitacionais foi comprometida com as novas regras de empréstimos para os entes federados e suas empresas (AZEVEDO, 2007, p. 17):

[...] no primeiro ano após a extinção do BNH - 1987 - as Companhias Habitacionais (Cohab) financiaram 113.389 casas populares. Durante o primeiro semestre de 1988, esse número caiu drasticamente para 30.646 unidades devido às mudanças da política habitacional a partir da Resolução 1464, de 26/02/88, do Conselho Monetário Nacional, e normas posteriores.

O endurecimento das regras para a utilização dos recursos, liberados para os entes com capacidade de endividamento, levou a uma limitação no financiamento das políticas nos Municípios mais pobres (CARDOSO, 2008, p. 5):

O resultado desse processo foi que, até 1998, quando mudaram radicalmente as regras de utilização, a distribuição dos recursos do FGTS revelou forte regressividade, já que somente os municípios mais ricos tiveram condições de acesso. Considerando-se que a crise financeira enfrentada pelos governos estaduais a partir do Plano Real limitou fortemente a sua capacidade de intervenção em programas sociais, os municípios mais pobres não puderam contar com recursos externos para investimento habitacional neste período.

Durante o mandato de Itamar Franco foram criados dois programas que buscavam a integração da ação do governo federal com Estados e Municípios: Programa Habitar Brasil e Programa Morar Município (Camila Pablo de LANNOY, 2006, p. 91): "Os programas na área da habitação popular foram redesenhados e passaram a exigir a participação de conselhos com participação comunitária dos governos locais e uma contrapartida financeira desses últimos investimentos da União.” Os projetos sofreram limitações ao desconsiderar as heterogeneidades das localidades, e diante da ausência de um fundo e conselho federais com recursos abundantes e regulares (AZEVEDO, 2007).

A idéia de condicionamento do financiamento do governo federal aos entes se destaca na estruturação dos programas (Marcio M. VALENÇA e Mariana F. BONATES, 2009, p. 4):

Esses programas introduziram muito do que seria 10 anos mais tarde um aspecto do Sistema Nacional de Habitação de Interesse Social, isto é, para acessarem os 
fundos no programa, as autoridades locais tinham que criar um conselho e um fundo (estadual ou municipal), bem como contribuir com uma parte do investimento (de 10 a 20\%, dependendo da região). Essas medidas, especialmente a primeira, garantiram participação e transparência no processo de gestão de ambos os programas. Os dois programas tiveram características similares, a diferença foi que o Habitar Brasil foi direcionado para cidades com mais de 50.000 habitantes e os fundos, neste caso, foram originados de um contrato de empréstimo com o Banco Interamericano de Desenvolvimento (BID). ${ }^{54}$

No governo de Fernando Henrique Cardoso (FHC), o setor passou por uma reestruturação (CARDOSO, 2008, p. 4-5):

Após a reorganização do setor, foram criadas novas linhas de financiamento, tomando como base projetos de iniciativa dos governos estaduais e municipais, com sua concessão estabelecida a partir de um conjunto de critérios técnicos de projeto e, ainda, da capacidade de pagamento dos governos sub-nacionais. No entanto, os recursos a fundo perdido, oriundos do Orçamento Geral da União tiveram uma utilização mais "frouxa", sendo distribuídos, em grande parte, a partir de emendas de parlamentares ao Orçamento da União.

Nesse governo foi criada a Secretaria de Política Urbana, mas ela se apresentou fraca institucional e politicamente, contando ainda com a fragmentação da atuação nessa política entre diversos ministérios (ABRUCIO, 2005). Além disso, a preocupação com a estabilização econômica e com o fim da hiperinflação, bem como a estruturação do Programa de Estímulo à Recuperação e ao Fortalecimento do Sistema Financeiro Nacional (PROER), como aponta Luciana Royer (2009), comprometeram os investimentos no setor (DIAS, 2012, p. 37): “Em resumo, a habitação como um todo foi sacrificada na renegociação redistributiva do Plano Real.”

Relevante é a modificação da organização dos atores e do rumo da política de habitação (ARRETCHE, 2002, p. 31):

[...] foi significativamente alterada a distribuição de competências entre municípios, estados e governo federal para a provisão de serviços sociais. Das 44 companhias municipais criadas pelo $\mathrm{BNH}, 12$ fecharam e mais de 20

\footnotetext{
${ }^{54}$ Tradução livre de: "These programs introduced much of what was 10 years later a feature of the Sistema Nacional de Habitação de Interesse Social (Social Housing National System), that is, in order to access funds in the program, local authorities had to set up a (state or municipal) council and a fund as well as to contribute with part of the investment (from 10 to $20 \%$, depending on region). These measures, especially the former, granted participation and transparency in the management process of both programs. Both programs had similar characteristics, the difference being that the Habitar Brazil was targeted to cities above 50,000 people and funds, in this case, originated from a loan contract with the Inter-American Development Bank (IDB)."
} 
redirecionaram suas atividades para a área de desenvolvimento urbano. A política social de habitação deixou de ser dominantemente produzida por intermédio de companhias municipais de habitação e passou a operar segundo linhas de crédito ao mutuário final.

Alguns programas foram desenvolvidos em âmbito nacional, como as Cartas de Crédito - mais importante destino dos recursos do FGTS e que passaram a possibilitar a aquisição de imóveis usados - e o Pró-moradia, modificando a configuração da política e comprometendo as companhias dos entes federados (ARRETCHE, 2002, p. 440):

Entre 1995 e 1998, a rede de empresas públicas de habitação recebeu 11,5\% dos recursos do FGTS, via Programa Pró-Moradia, e 28\% dos recursos destinados ao Programa Carta de Crédito Associativo. O Programa de Carta de Crédito Individual, por sua vez, recebeu $76 \%$ desses recursos, utilizados majoritariamente para a aquisição de imóveis usados. Portanto, via gestão seletiva das linhas de crédito, ocorreu uma inflexão significativa na política habitacional: de um modelo centrado no financiamento à produção de habitações novas, e assentado em uma rede de prestadoras públicas, para um modelo centrado no financiamento ao mutuário final e, particularmente, destinado à aquisição de imóveis usados.

A criação do Sistema de Financiamento Imobiliário (SFI) pela lei no 9.514/1997 demonstrou uma aposta no desenvolvimento do mercado para o incremento da produção habitacional. No entanto, esse sistema não é voltado à produção de interesse social e tem sido utilizado, predominantemente, para imóveis comerciais, possibilitando um relacionamento entre o mercado imobiliário e o mercado de capitais, incluindo, dessa maneira, novos atores.

Antes de FHC assumir o segundo mandato, foi anunciada a recriação em âmbito federal de um Ministério para tratar da questão urbana e da habitação, mas isso não se concretizou (ABRUCIO, 2005). Somente no governo Lula tal ministério foi criado.

\subsection{Ministério das Cidades}

Em 2003, com a criação do Ministério das Cidades, há a institucionalização de uma política de habitação pelo governo central, mas com diversas questões limitadoras, como a fraqueza política do ministério, a preocupação prioritária com o superávit primário e as restrições orçamentárias, como aponta Ermínia Maricato (2011, p. 52), que participou do governo na época:

As restrições orçamentárias eram tão rígidas que em 2004 o MCidades permaneceu de janeiro a abril sem abertura de orçamento do ano e até o mês de 
dezembro com o contingenciamento de $60 \%$ dos investimentos previstos na LOA (Lei Orçamentárias Anual), aprovada no Congresso Nacional.

Uma das questões relevantes a ser destacada nas limitações do Ministério é que o problema habitacional tem uma conexão bastante importante com a política econômica, fazendo com que, muitas vezes, as decisões cruciais da política fiquem fora de sua governabilidade (MARICATO, 2011, p. 118):

a moradia é uma mercadoria especial. Ela demanda terra, ou melhor, terra urbanizada, financiamento à produção e financiamento para a venda. Neste sentido, ela tem uma vinculação com a macro-economia já que o mercado depende de regulação pública e subsídios ao financiamento. Ao disputar investimentos com outros ativos financeiros, ela exigiria mover o coração da política econômica.

Atualmente, o ministério é um dos atores do Sistema Nacional de Habitação de Interesse Social (SNHIS), financiando a estrutura administrativa do Fundo Nacional de Habitação de Interesse Social (FNHIS), organizando as Conferências das Cidades, apoiando o Conselho das Cidades (ConCidades) e decidindo sobre a aceitação de propostas e a alocação de recursos do fundo. 


\section{Capítulo 3: SISTEMA NACIONAL DE HABITAÇÃO DE INTERESSE SOCIAL}

\section{Histórico da criação do SNHIS}

A lei que criou o Sistema Nacional de Habitação de Interesse Social (SNHIS) - n $^{\circ}$ 11.124/2005 - teve origem no projeto de lei (PL) no 2.710/1992. Sob o patrocínio dos movimentos de moradia, o projeto foi o primeiro de iniciativa popular apresentado depois da CF88, tendo sido levado à Câmara dos Deputados em novembro de 1991, reunindo mais de 800.000 assinaturas de 18 Estados da federação.

$\mathrm{Na}$ época, propôs-se que o Fundo Nacional de Moradia Popular fosse regido segundo as diretrizes de um Conselho, mas com uma composição diferente da atual: "Art. $7^{\circ}$ O Conselho Nacional de Moradia Popular será constituído por 10 (dez) representantes de entidades do movimento popular de moradia juridicamente constituídas, 4 (quatro) representantes das centrais sindicais, 1 (um) representante do Ministério da Ação Social, 1 (um) representante da Caixa Econômica Federal, 1 (um) representante do Ministério Público Federal, 1 (um) representante do Congresso Nacional e 1 (um) representante do Banco Central." Durante a tramitação do PL, incluiu-se a participação de empresários do setor e foi reduzida a participação dos movimentos populares. De todo modo, nem a composição original, nem a atual definiram vagas no conselho para os governos estaduais e municipais.

Além da composição, o projeto de lei definia qual população seria atendida, considerando de baixa renda "a população moradora em precárias condições de habitabilidade, favelas, palafitas, habitações coletivas de aluguel, cortiços, áreas de risco ou população que tenha renda igual ou inferior a 10 (dez) salários mínimos vigentes no país". Havia uma determinação de que $70 \%$ dos candidatos a financiamento deveriam ser da faixa de zero a cinco salários mínimos e $30 \%$ para a faixa de cinco a dez salários mínimos. Atualmente, a lei do SNHIS não define os critérios da "população de menor renda" que busca atender, muito menos a quantidade de financiamentos que são destinados a cada faixa de renda. Essa definição de priorização da população de menor renda com a especificação de quem ela é seria muito salutar para a política habitacional não se voltar prioritariamente à classe média, já que o déficit habitacional está concentrado na faixa de renda mais baixa: famílias que ganham mensalmente de zero a cinco salários mínimos 
representam 95,9\% do déficit habitacional urbano no Brasil, segundo o Ministério das Cidades (2009a).

O projeto de lei previa também uma grande diversidade de programas habitacionais como a construção de moradias e a locação de interesse social; algumas dessas ações prosseguiram na lei, e tornou-se possível acrescentar novos programas, se forem aprovados pelo Conselho Gestor do Fundo.

Numa publicação do Ministério das Cidades (2004) são previstas adesões provisórias e adesões integrais, mas que não são utilizadas no modelo final. Segundo Nabil Bonduki (2013, p. 34), o sistema incluiria numa proposta inicial, a definição de entes com adesão integral ou parcial:

[...] no caso da adesão parcial, os recursos do FNHIS estariam acessíveis mediante a apresentação e aprovação de projetos a serem apoiados, enquanto os entes que obtivessem a adesão integral receberiam recursos para implementar sua política de forma autônoma, por transferência automática ao respectivo fundo, de acordo com os critérios estabelecidos pelo Conselho Gestor do Fundo Nacional.

O PlanHab (MCIDADES, 2009b), em seu eixo institucional, propunha a criação do Índice de Capacidade Institucional Habitacional e de Gestão Urbana para premiar com maior acesso aos recursos federais os entes que se qualificassem para gerir o setor habitacional com desenvolvimento institucional e utilização de instrumentos da política habitacional, urbana e fundiária, classificando-os em gestão plena, semiplena e básica. A classificação seria fruto da composição de alguns indicadores com informações sobre a existência de órgãos, pessoal e ações voltadas à habitação de interesse social, a atuação dos conselhos locais, a execução de contratos com o Ministério das Cidades, a captação de recursos locais e execução das despesas em habitação, entre outras informações. Desse modo, o governo federal premiaria os Municípios que se esforçassem mais para estruturar uma política de habitação de interesse social.

No entanto, o desenho final do sistema subordinou todos os aderentes à apresentação de projetos para aprovação, independentemente do seu desenvolvimento institucional, e ainda não se efetivaram reformas no modelo. ${ }^{55}$

\footnotetext{
${ }^{55}$ O projeto de lei $n^{\text {o }} 3.057 / 2000$, que altera a lei de parcelamento do solo, apresenta uma diferenciação de Municípios com gestão plena - com plano diretor, órgãos colegiados de controle social e órgãos executivos específicos de politica urbana ou ambiental. Tais Municípios teriam maior autonomia e flexibilidade nos critérios urbanísticos estabelecidos nacionalmente.
} 
No $1^{\circ}$ e no $2^{\circ}$ substitutivo ao PL apresentados em 1997 foi proposta uma composição do conselho diversa, contando com representantes do governo estadual e municipal, além de vincular 70\% dos recursos do FGTS e do SBPE para a constituição do fundo, mais heranças jacentes e produtos apreendidos pela Receita Federal; essas fontes de recursos e essa composição do conselho que incluía os entes federados foram retiradas no texto final.

Apesar de diversas alterações na redação, a vinculação do repasse à criação de conselhos e fundos pelos entes federados e a operação do fundo sendo executada pela CEF permaneceram. Após 13 anos de tramitação, o projeto foi aprovado, tendo sido apostos vetos que foram mantidos pelo Congresso Nacional.

Entre os vetos, encontra-se o do parágrafo único do artigo $7^{\circ}$ : "As dotações relativas aos programas referidos no caput deste artigo serão centralizadas no FNHIS a partir da publicação desta Lei”. Tal veto foi justificado pelo Ministério do Planejamento, Orçamento e Gestão pela dificuldade em centralizar todos os recursos para habitação no fundo sem prejudicar as ações em andamento: "O parágrafo único do art. $7^{\circ}$ quando combinado com o disposto no inciso III do art. $8^{-}$do projeto de lei, torna-se impraticável, sendo obrigatória a abertura de crédito especial para remanejamento de todas as dotações atualmente classificadas com a função habitação, independentemente do órgão orçamentário a que estejam vinculadas, de forma que sejam agrupadas na unidade orçamentária a ser criada para o FNHIS. [...] Convém ressaltar que o veto não trará prejuízo à centralização das programações que constituem o FNHIS em exercícios futuros, uma vez que se aplica ao exercício de 2005." Atualmente, sem a obrigatoriedade legal é possível verificar que os valores da função habitação são correspondentes aos valores do FNHIS, mas isso não garante que os recursos das políticas habitacionais estejam vinculados ao fundo.

\section{Sistema Nacional de Habitação de Interesse Social}

Integram o SNHIS: Ministério das Cidades, Conselho Gestor do FNHIS, Caixa Econômica Federal, Conselho das Cidades, conselhos estaduais e municipais com atribuições relacionadas a questões urbanas e habitacionais, órgãos estaduais, municipais e metropolitanos relacionados à habitação, fundações, sociedades, sindicatos, associações comunitárias, cooperativas habitacionais e quaisquer outras entidades privadas que desempenhem atividades na área habitacional, afins ou complementares e agentes 
financeiros autorizados pelo Conselho Monetário Nacional a atuar no Sistema Financeiro da Habitação (SFH).

Os recursos do SNHIS têm origem no Fundo de Amparo ao Trabalhador (FAT), no Fundo de Garantia do Tempo de Serviço (FGTS), Fundo Nacional de Habitação de Interesse Social (FNHIS), e de outros fundos ou programas que vierem a ser incorporados ao SNHIS. Já o FNHIS é constituído por recursos do Fundo de Apoio ao Desenvolvimento Social (FAS), outros fundos ou programas que vierem a ser incorporados, dotações do Orçamento Geral da União classificados na função habitação, recursos provenientes de empréstimos externos e internos, contribuições e doações de pessoas físicas ou jurídicas, entidades e organismos de cooperação nacionais e internacionais, receitas operacionais e patrimoniais de operações realizadas com recursos do FNHIS, receitas decorrentes da alienação dos imóveis da União que lhe vierem a ser destinadas, e outros recursos que lhe vierem a ser destinados. A configuração do fundo como orçamentário, contando apenas com repasses de recursos do orçamento e sob suas regras trouxe críticas (Evaniza L. RODRIGUES, 2013, p. 53): “Com isso, as principais fontes de recursos utilizados na habitação, especialmente o FGTS, integraram o SNHIS, mas não o FNHIS, como propunham os movimentos sociais desde a proposição do FNMP, em 1991."

As diretrizes do SNHIS, apesar de não serem garantidas com metas objetivas incluem algumas reivindicações dos movimentos populares, como a utilização de terrenos de propriedade do poder público, a prioridade para a população de menor renda e o aproveitamento prioritário de áreas dotadas de infraestrutura e subutilizadas.

A descentralização dos recursos por meio do FNHIS se materializa com transferências voluntárias da União aos Estados, Municípios e Distrito Federal. A lei ${ }^{\circ}$ 11.578/2007 modificou a lei $\mathrm{n}^{\mathrm{o}} 11.124 / 2005$, possibilitando que os recursos do FNHIS possam ser utilizados por entidades privadas sem fins lucrativos que tenham objeto social compatível com o projeto a ser implementado com os recursos repassados e que sejam constituídas há pelo menos três anos, selecionadas por meio de chamadas públicas.

A adesão dos entes federados foi bastante significativa (ARRETCHE et al., 2012, p. 103): "até o início de 2012, a grande maioria dos municípios brasileiros $(96,9 \%)$ firmou o termo de adesão junto ao Sistema Nacional de Habitação de Interesse Social. Ou seja, dos 5.565 municípios existentes no País, 5.392 aderiram.” Todos os Estados também já haviam aderido. 


\section{Atores da política habitacional}

A política habitacional inclui uma série de atores em uma complexa organização institucional, não sendo possível nesse trabalho esgotar o rol de todos aqueles que influenciam, decidem e constroem a política habitacional no país. A seguir, serão destacados alguns atores que tem papel relevante na política habitacional e algum poder de decisão, ainda que não façam parte do SNHIS, já que sua atuação tem consequências para o sistema, e os limites entre os sistemas de interesse social e de mercado não são completamente claros. A descrição é bastante sintética, desconsiderando todas as heterogeneidades existentes no interior dos atores.

\subsection{Conselhos}

A palavra 'conselho' é amplamente utilizada na legislação sem muita precisão, indicando diversos colegiados de diferentes formações; desse modo, em diversos diplomas legais são considerados conselhos tanto aqueles que reúnem a sociedade civil e o Estado em negociações sobre políticas públicas, quanto reuniões de secretários ou ministros como o Conselho Monetário Nacional.

Desde a Constituição de 1988, os conselhos com participação da sociedade civil para decisões de questões setoriais ganharam importância (Luciana TATAGIBA, 2002, p. 54): “Os conselhos gestores de políticas públicas são, portanto, espaços públicos de composição plural e paritária entre Estado e sociedade civil, de natureza deliberativa, cuja função é formular e controlar a execução das políticas públicas setoriais."

Nesse tópico serão abordados todos os grupos que se autodenominam conselhos, ainda que se considere que os conselhos, em sentido estrito, sejam apenas os que incorporem a participação popular.

\subsubsection{Conselho Monetário Nacional}

O Conselho Monetário Nacional (CMN) foi criado pela lei $n^{\circ} 4.595 / 1964$ e é o responsável por autorizar as instituições financeiras a atuar no Sistema Financeiro de Habitação e, portanto, no SNHIS também. O conselho determina aspectos financeiros da política como subsídios e taxas de juros, sendo o sucessor do BNH em algumas 
atribuições. É composto pelo Ministro da Fazenda, pelo Ministro do Planejamento, Orçamento e Gestão, e pelo Presidente do Banco Central do Brasil (BC).

As resoluções do CMN modificam a política habitacional, especialmente porque ela se apresenta no Brasil extremamente ligada ao financiamento de unidades habitacionais, como aponta Royer (2009, p. 123): “quem normatiza as condições da operacionalização do SFH, determinando o que está incluído ou não no sistema, o que pode ser considerado uma operação de financiamento habitacional do SFH, é o Conselho Monetário Nacional."

O CMN foi responsável pelo aumento da disponibilidade de crédito devido a mudanças vindas de suas resoluções, conforme aponta Bonduki (2008, p. 100):

Em 2005, o Conselho Monetário Nacional emitiu Resolução obrigando os bancos a investirem em financiamento habitacional uma porcentagem de recursos captados através da poupança (SBPE - Sistema Brasileiro de Poupança e Empréstimo). Embora por lei os bancos já estivessem obrigados a fazer este investimento, resoluções anteriores, desde a crise dos anos 80, liberaram as instituições financeiras para investirem em habitação, abrindo a possibilidade de aplicarem estes recursos no Banco Central, em título da dívida pública, onde rendiam muito mais. Com as alterações, o crescimento das aplicações de mercado foi muito expressivo e em três anos a produção com recursos do SBPE triplicou.

O financiamento no âmbito do Sistema Brasileiro de Poupança e Empréstimo (SBPE), que não é voltado à população de mais baixa renda e não faz parte do SNHIS, cresceu: de $\mathrm{R} \$ 4.564 .000 .000,00$ e 59.873 unidades financiadas em 2005 para $\mathrm{R} \$ 76.530 .000 .000,00$ em 423.019 unidades financiadas em 2012 (BC, 2005-2012). A distribuição dos financiamentos foi bastante desigual pelo território brasileiro, em dezembro de 2011, por exemplo, 63,89\% do valor dos financiamentos estavam concentrados no Sudeste, $13,22 \%$ no Sul, $10,39 \%$ no Nordeste, $7,68 \%$ no Centro-Oeste e $4,82 \%$ no Norte.

É possível constatar que o volume de recursos e o número de unidades financiadas aumentou, assim como o valor médio do financiamento mais do que dobrou: de $\mathrm{R} \$ 73.042,38$ em 2005, para $\mathrm{R} \$ 162.318,99$ em 2012. No mesmo período, se observa aumentos: na renda da população, na captação da poupança e no preço dos imóveis acima da inflação em grande parte dos Municípios. ${ }^{56}$ Esse aumento de preço pode não ser

\footnotetext{
${ }^{56} \mathrm{O}$ acumulado do índice Fipe/ZAP de preço de imóveis anunciados para São Paulo de jan/2008 a dez/2011 foi de $123,8 \%$, enquanto o Índice Nacional de Preços ao Consumidor Amplo (IPCA) do mesmo período foi de 23,9\%. O índice composto para Recife, Fortaleza, Salvador, Distrito Federal, Belo Horizonte, Rio de
} 
decorrência exclusiva do crescimento do crédito habitacional, mas é possível perceber relações entre os fenômenos; desse modo, o financiamento SBPE, que não está dentro do SNHIS, influencia diretamente os resultados da política para população de baixa renda, já que impacta as soluções habitacionais de interesse social, especialmente com o aumento do preço da terra. Entre os motivos apontados no PlanHab (2008, p.77-8) para o crescimento dos financiamentos está o ambiente macroeconômico favorável, maior segurança jurídica devido ao avanço na regulação e redução da tributação. É claro que esse modelo tem seus limites: nível de endividamento da população, concentração de renda, longo prazo dos financiamentos, entre outros.

As definições desse conselho modificam o volume de recursos destinado ao financiamento habitacional, como na resolução $n^{\circ} 3.932 / 2010$ - precedida de outras, em que o CMN definiu que $65 \%$ dos recursos captados em depósito de poupança deviam ser aplicados em operações de financiamento habitacional, sendo que $80 \%$ desses em operações do Sistema Financeiro de Habitação (SFH) e os outros $20 \%$ a taxas de mercado (TM). Nessa resolução há as conceituações do que pode ser incluído nessa definição, como financiamentos para produção e aquisição de material para construção e cédulas hipotecárias, letras de crédito imobiliário, certificados de recebíveis imobiliários.

Janeiro e São Paulo variou de ago/2010 a dez/2011: 37,6\% e o IPCA do período foi de 9,4\%. A variação do índice para aluguel em São Paulo de jan/2008 a dez/2011 foi de 65\%. Disponível em: <http://www.zap.com.br/imoveis/fipe-zap/>. Acesso em 15.07.2013. Os dados são baseados em anúncios de imóveis no site 〈http://www.zap.com.br/imoveis> e estão disponíveis a partir de jan/2008 para alguns Municipios brasileiros. De 2005 a 2011, o INCC (Índice Nacional de Custo da Construção) variou 48,21\%. Outro indicador disponível para ilustrar o aumento do preço dos imóveis é o Índice de Valores de Garantia de Imóveis Residenciais Financiados (IVG-R), publicado pelo Banco Central ele mensura a tendência de longo prazo dos valores de imóveis residenciais no Brasil utilizando informações do Sistema de Informações de Crédito (SCR): o acumulado de jan/2005 a dez/2011 foi de 326,39\%. Utiliza-se para cálculo do índice os valores de avaliação dos imóveis vinculados a financiamentos imobiliários a pessoas físicas com garantia de hipoteca residencial ou alienação fiduciária de imóvel nas 11 regiões metropolitanas utilizadas para o cálculo do IPCA pelo IBGE (Belém, Belo Horizonte, Brasília, Curitiba, Fortaleza, Goiânia, Porto Alegre, Recife, Rio de Janeiro, Salvador e São Paulo). Disponível em: 〈https://www3.bcb.gov.br/sgspub/consultarvalores/consultarValoresSeries.do?method=consultarValores > Acesso em 15.07.2013. 


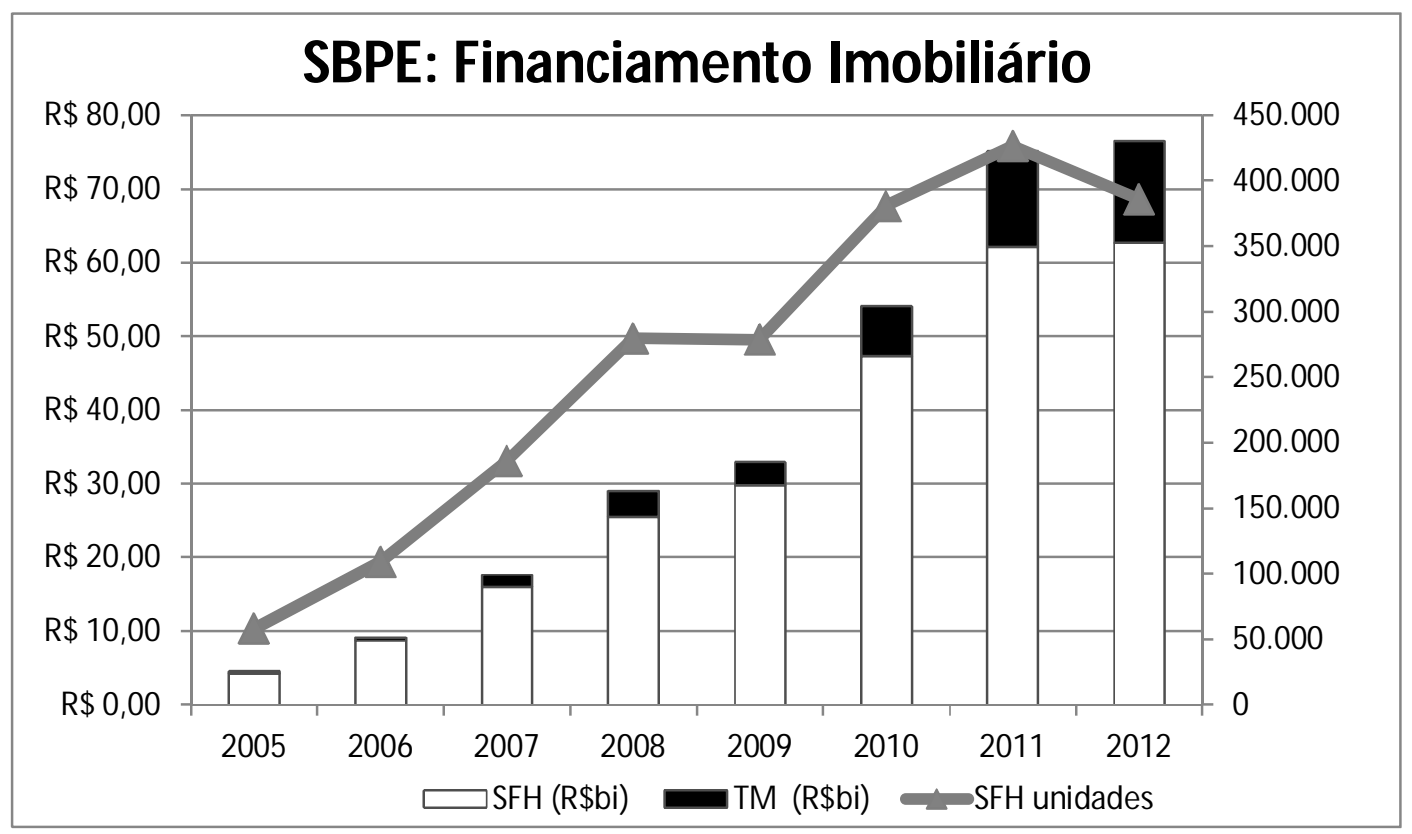

Fonte: BC, 2005-2012. ${ }^{57}$

A relevância do conselho pode ser demonstrada também pela utilização das resoluções para incentivar e estruturar o Sistema de Financiamento Imobiliário (SFI), como observa Luciana Royer (2009, p. 124), as resoluções desse conselho e do Conselho Curador do FGTS direcionaram parte do dinheiro do FGTS para o financiamento do SFI, ou seja, resoluções desses conselhos possibilitaram a diminuição dos recursos destinados à população de baixa renda:

Essa série de resoluções do CMN e do CGFGTS, editadas praticamente ano a ano desde 1998, mostram que os CRI e outros títulos da mesma natureza foram ganhando espaço no mercado de capitais, ampliando sua participação na captação de recursos que seriam destinados inicialmente para o atendimento a baixa renda, como o FGTS.

Como no BNH, mas dessa vez com a utilização de um sistema mais complexo com a emissão de títulos negociáveis no mercado financeiro, o SFI se apropria de recursos do SBPE e do FGTS utilizando-se do pretexto de combate ao déficit habitacional (ROYER, 2009, p. 133):

A propalada superioridade do SFI em relação à operacionalização e capacidade de captação de recursos e a confusão entre os objetos de financiamento do SFI e do SFH vão, aos poucos, rompendo a barreira distintiva entre um modelo estruturado pela livre captação de recursos no mercado financeiro. E, assim como já ocorrera com o SFH nos tempos do BNH, tal confusão permite que os

\footnotetext{
${ }^{57}$ Os valores desse e de todos os gráficos do trabalho não foram deflacionados.
} 
recursos do SBPE e do FGTS sejam canalizados para o financiamento de unidades de maior valor, por famílias de maior poder aquisitivo, em um processo concentrador de renda e de riqueza.

\subsubsection{Conselho Curador do FGTS}

O Fundo de Garantia do Tempo de Serviço (FGTS) foi criado pela lei $\mathrm{n}^{\circ}$ 5.107/1966. Ele fornece recursos para a habitação popular e pode ser utilizado pelo trabalhador com vínculo formal de emprego, para a aquisição de moradia própria. $\mathrm{O}$ fundo era gerenciado pelo $\mathrm{BNH}$, a lei ${ }^{\circ} 8.036 / 1990^{58}$ estabeleceu que $60 \%$ das aplicações seriam destinadas à habitação popular.

Atualmente, a gestão do Fundo deve seguir o planejamento e as normas gerais do Conselho Curador do FGTS (CCFGTS). Esse Conselho sempre foi formado por representantes da sociedade civil e do governo federal. Em uma das suas regulamentações - o decreto-lei 2.408/1988, que já foi revogado, previu-se a participação de representantes dos governos estadual e municipal, ainda que indicados pelo Ministro da Habitação, Urbanismo e Meio Ambiente. Apenas a partir de 1989, o Conselho Curador passou a funcionar efetivamente, anteriormente ele era "[...] presidido pelo $\mathrm{BNH}$, que na prática administrava sozinho o Fundo, sob orientação do governo.” (CAIXA, 2010, p. 14).

Tendo em vista o papel de destaque do FGTS na provisão de recursos para a política habitacional no Brasil, o Conselho Curador tem grande relevância, já que a aplicação dos recursos do fundo é condicionada às suas regras. No entanto, não há representantes dos entes federados em sua composição, sendo ele formado por dez representantes do governo federal, um da CEF, um do Banco Central, seis representantes dos trabalhadores e seis representantes dos empregadores.

Na resolução do CCFGTS nº 181/1995 foi aprovado o programa Pró-moradia, de atendimento habitacional por meio do Poder Público e na resolução no 460/2004 foram estabelecidos os percentuais destinados a habitação popular em cada ente federado, conforme destaca Bonduki (2008, p. 100):

[...] no que se refere ao Subsistema de Interesse Social, o grande salto ocorreu com a Resolução 460 do Conselho Curador do FGTS, que tornou possível uma massiva aplicação de recursos deste, que é o principal fundo para investimento

\footnotetext{
${ }^{58}$ Já havia tal previsão na lei n ${ }^{\circ} 7.839 / 1989$.
} 
habitacional, em subsídios habitacionais, cujo montante atingiu, em 2006 e 2007, 1,8 bilhões de reais anuais.

A destinação dos recursos, o teto do valor dos imóveis a serem financiados e a conceituação do que é habitação popular ${ }^{59}$ devem ser estabelecidos pelas resoluções desse conselho, restando evidente que suas decisões são determinantes na configuração da política pública, no destino dos recursos, na formatação das modalidades de atendimento.

Assim como o financiamento no âmbito do SBPE, o FGTS, que atinge uma população com renda menor, também ampliou seu crédito, mas não na mesma proporção: passou de $\mathrm{R} \$ 4,204$ bilhões de reais e 292.891 unidades em 2005 a $\mathrm{R} \$ 35,096$ bilhões e 510.304 unidades em 2012, conforme FGTS (2006-2013):

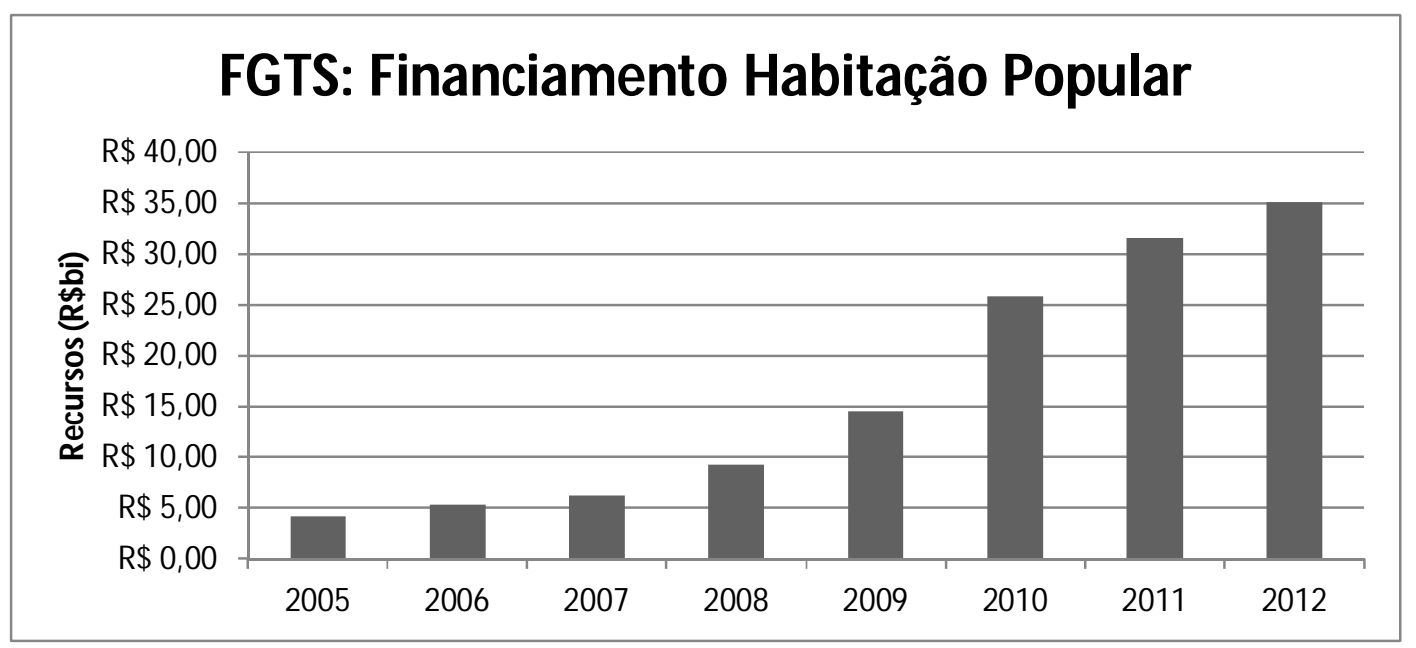

Fonte: Demonstrações Contábeis do FGTS 2005-2012.

A resolução n $n^{\circ}$ 375/2001 do CCFGTS possibilitou a utilização de recursos do fundo para a aquisição de Certificados de Recebíveis Imobiliários (CRIs) com limitações no valor do financiamento e no valor das unidades habitacionais. A resolução nº 390/2002, retirou essas limitações: “considerando que a redação dada ao item 2 da Resolução no 375/2001 não contempla os objetivos de incremento da produção e contribuição do CRI para a ampliação do número de novos lançamentos no setor imobiliário, com reflexos positivos na contratação de mão-de-obra e na dinamização desse importante setor da economia nacional, conforme ficou consensado na aprovação da referida Resolução por parte deste Conselho". Além disso, a resolução n 578/2008, alterada pela n 637/2010, permitiu a

\footnotetext{
${ }^{59}$ Conforme a resolução do CCFGTS no 702/2012: as operações de financiamento de habitação popular são destinados às pessoas físicas: definidas como famílias com renda familiar mensal limitada a R\$ 4.300,00, admitida sua elevação até $\mathrm{R} \$ 5.400,00$ nos casos de financiamentos vinculados a imóveis situados em Municípios integrantes de regiões metropolitanas ou equivalentes, Municípios-sede de capitais estaduais, ou Municípios com população igual ou superior a 250.000 habitantes.
} 
aquisição de cotas de Fundos de Investimento Imobiliário e de Fundos de Investimento em Direitos Creditórios e debêntures.

É relevante notar como a habitação é usada como justificativa para a alocação de recursos do FGTS em Fundos de Investimentos, como na resolução no 602/2009: "Considerando que o setor imobiliário é fundamental no processo de crescimento da economia brasileira e que a habitação é o objetivo principal da aplicação dos recursos do FGTS”.

Desse modo, as resoluções possibilitaram a utilização de um recurso, que deveria ser prioritariamente usado para a população de baixa renda, para a compra de CRIs e outros títulos para favorecer o SFI, que tem como foco o retorno ao investidor e não o fim do déficit habitacional. Tal aspecto é apontado no produto 3 do PlanHab (2008, p. 67):

\begin{abstract}
Além disso, entendemos que pelas características e objetivos do FGTS, suas dotações orçamentárias devam se voltar exclusivamente para os financiamentos. Os recursos para aquisição de CRIs e estímulo ao desenvolvimento do mercado secundário deveriam, assim, ser buscados em outras fontes.
\end{abstract}

\title{
3.1.3. CODEFAT
}

O Fundo de Amparo ao Trabalhador (FAT), criado pela lei no 7.998/1990, também é uma das fontes de recursos do sistema. As decisões sobre a destinação dos recursos passam pelo Conselho Deliberativo do Fundo de Amparo ao Trabalhador (CODEFAT) constituído por seis representantes do governo federal, seis dos empregados e seis dos empregadores - e devem ser voltadas ao pagamento do abono salarial, do segurodesemprego, ao financiamento de programas de educação profissional e tecnológica e de desenvolvimento econômico. ${ }^{60}$

\subsubsection{Conselho Curador do Fundo de Desenvolvimento Social}

O Conselho Curador do Fundo de Desenvolvimento Social (CCFDS) é formado por seis membros do governo federal, três representantes dos empregados e três representantes dos empregadores. A presidência do Conselho, a partir da lei $\mathrm{n}^{\circ} 10.683 / 2003$, passou a ser do Ministro das Cidades.

\footnotetext{
${ }^{60}$ Em resposta ao pedido de informação formulado pela autora, o Ministério do Trabalho e Emprego comunicou que não há recursos do FAT sendo utilizados em projetos habitacionais.
} 
Por meio de uma resolução ad referendum do CCFDS, resolução no 141/2009, o Ministro das Cidades criou o Programa Minha Casa, Minha Vida Entidades (PMCMV-E), que é voltado à produção de habitação por pessoas organizadas em cooperativas habitacionais ou mistas, associações e demais entidades privadas sem fins lucrativos. O fundo foi fonte de recursos do Programa Crédito Solidário, também voltada a entidades.

\subsubsection{Conselho Gestor do FNHIS}

O Conselho Gestor do FNHIS é um órgão de caráter deliberativo, que determina as diretrizes e critérios para a alocação dos recursos do fundo. A lei que o criou determinou que sua composição, a ser definida por regulamento do poder executivo, seria formada de forma paritária por órgãos e entidades do Poder Executivo, e representantes da sociedade civil.

No entanto, o decreto $\mathrm{n}^{\circ} 5.796 / 2006$ determinou que apenas representantes do executivo do governo federal seriam membros do conselho. As decisões são tomadas por maioria simples, com a presença de no mínimo metade de seus membros, com a presidência do conselho exercida por um representante do Ministério das Cidades segundo o decreto, o próprio Ministro - com o voto de qualidade. O conselho é formado por doze representantes do governo federal, quatro representantes de entidades da área dos movimentos populares, três representantes de entidades da área empresarial, três representantes de entidades da área de trabalhadores, um representante de entidade da área profissional, acadêmica ou de pesquisa e um representante de organização nãogovernamental.

O CGFNHIS publica resoluções com as diretrizes gerais do Fundo, os programas existentes e outras determinações da política, teoricamente, observando a lei do FNHIS, a Política e o Plano Nacional de Habitação estabelecidos pelo Ministério das Cidades e as diretrizes do Conselho das Cidades. Além disso, aprova orçamentos e planos anuais e plurianuais, delibera sobre as contas e dirime dúvidas sobre as normas aplicáveis ao FNHIS.

\subsubsection{Conselho das Cidades}

O Conselho das Cidades (ConCidades) surgiu legalmente como Conselho Nacional de Desenvolvimento Urbano na medida provisória $\mathrm{n}^{\circ}$ 2.220/2001, tendo ganhado sua 
denominação atual pela lei no $10.683 / 2003$. Sua regulamentação e instalação se deu a partir do decreto $\mathrm{n}^{\circ} 5.031 / 2004$, modificado pelo decreto $\mathrm{n}^{\circ} 5.790 / 2006$.

O conselho é composto de 86 membros: 16 representantes do Poder Público Federal (três representantes são do Ministério das Cidades, sendo o Ministro o presidente do conselho, um da Casa Civil, um do Ministério da Cultura, um do Ministério da Fazenda, um do Ministério da Integração Nacional, um do Ministério da Saúde, um do Ministério do Desenvolvimento Social e Combate à Fome, um do Ministério do Meio Ambiente, um do Ministério do Planejamento, Orçamento e Gestão, um do Ministério do Trabalho e Emprego, um do Ministério do Turismo, um do Ministério da Ciência e da Tecnologia, um da Secretaria de Relações Institucionais da Presidência da República e um da Caixa Econômica Federal), nove representantes do Poder Público Estadual, do Distrito Federal ou de entidades civis de representação do Poder Público Estadual e do Distrito Federal, observado o critério de rodízio entre os Estados, o Distrito Federal e as entidades civis, 12 representantes do Poder Público Municipal ou de entidades civis de representação do Poder Público Municipal, 23 representantes de entidades dos movimentos populares, oito representantes de entidades empresariais, oito representantes de entidades de trabalhadores, seis representantes de entidades profissionais, acadêmicas e de pesquisa, e quatro representantes de organizações não governamentais. Esse conselho, além de contar com a participação de representantes dos entes federados, conta com uma porcentagem de membros de movimentos populares superior ao exigido pelo SNHIS: $26,74 \%$.

No entanto, sua participação é mais limitada, pois apenas fornece subsídios para as decisões e planos, tendo ainda seu formato definido unicamente pelo Executivo do governo federal, assim como o CGFNHIS (SANTOS JR et al., 2006, p. 19):

\footnotetext{
Além disso, sob o ponto de vista do Fórum Nacional de Reforma Urbana, há um limite relacionado ao fato do decreto presidencial definir o Conselho das Cidades como uma esfera consultiva e deliberativa, mas só definir atribuições consultivas. Atualmente a capacidade deliberativa do Conselho é muito mais resultante da sua força social - o fato dele ser composto por segmentos representativos dos setores sociais ligados à política urbana - do que uma definição legal. E nesse aspecto existem riscos de retrocessos, já que não há nenhuma garantia que os próximos governos mantenham o compromisso em adotar as deliberações tomadas no seu interior.
}

A participação do ConCidades no SNHIS tem sido limitada às resoluções recomendadas em que o conselho apenas sugere mudanças que não são de sua competência. Nas resoluções recomendadas n 3/2005, nº 14/2006, nº 16/2006, nº 27/2006 
e n ${ }^{o}$ 35/2007: são sugeridas ações e o envio de recursos para o fundo. Já nas resoluções no

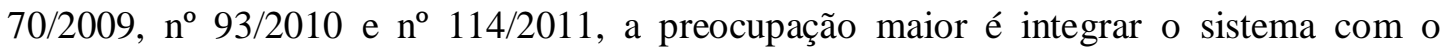
PMCMV e o PAC, especialmente por conta do esvaziamento do fundo decorrente da priorização desses programas.

\subsubsection{Conselhos estaduais e municipais}

Os recursos só podem ser aplicados nos entes federados que apresentarem planos de habitação de interesse social, constituírem fundos de habitação de interesse social e conselhos com no mínimo $1 / 4$ das vagas destinadas a representantes dos movimentos populares.

No entanto, diversos conselhos não cumpriram essas exigências e o controle realizado sobre eles parece ser apenas formal, sobre sua constituição, não se ligando ao cumprimento dos requisitos.

No Estado de São Paulo, por exemplo, por meio da lei $n^{\circ} 12.801 / 2008$, o Poder Executivo foi autorizado a regulamentar a composição do Conselho Gestor do Fundo Paulista de Habitação de Interesse Social, o que foi realizado por meio do decreto $\mathrm{n}^{\mathrm{o}}$ 53.823/2008. Tal decreto estipulou que a composição seria de: quatro representantes do Poder Executivo estadual, quatro representantes da sociedade civil (um de organizações populares de representação estadual, um de organizações de agentes financeiros e dois representantes das organizações de agentes promotores privados empresariais). Desse modo, a participação dos movimentos populares ficou reduzida a 12,5\% dos membros, a metade do necessário no sistema.

Essa divergência com o sistema nacional gerou uma proposta de decreto legislativo na Assembleia Legislativa de São Paulo: no 50/2009 para a revogação do decreto por essa desconformidade, mas ela foi arquivada. O Conselho Gestor do Fundo Garantidor, instituído pelo decreto estadual $\mathrm{n}^{\circ} 53.823 / 2008$, não tem nenhum membro de movimentos populares, contando com a participação de representantes do governo estadual, de empresários e de agentes financeiros.

Todos os Estados, atualmente, têm a presença de conselhos de habitação (IBGE, 2012), nos Municípios essa presença tem aumentado, mas em 2009 apenas $9 \%$ os tinham (IBGE, 2009).

Se o simples acompanhamento da Constituição já se mostra deficiente, o efetivo funcionamento dos conselhos é mais duvidoso ainda; por se tratar de uma obrigação para 
obter o financiamento federal no sistema, os entes federados podem constituir conselhos legalmente, ainda que não os instalem de fato.

A resolução $n^{\circ} 2 / 2006$ do CGFNHIS, em seu artigo $2^{\circ}, \S 6^{\circ}$, estabeleceu a competência dos conselhos estaduais e locais para fixar critérios para a priorização de linhas de ação, alocação de recursos e atendimento dos beneficiários dos programas habitacionais, para promover ampla publicidade dos critérios e modalidades de acesso e para debater e avaliar esses critérios. No entanto, tal previsão é limitada pelos padrões estabelecidos nacionalmente, já que o acesso aos programas é restrito às modalidades escolhidas em âmbito federal.

\subsection{Conferências das Cidades}

As Conferências das Cidades não são atores, mas apresentam recomendações para as políticas públicas por meio de representantes do Estado e da sociedade civil nos três níveis de governo. Elas se inserem no contexto da gestão democrática das cidades, estabelecidas pelo Estatuto da Cidade: lei $\mathrm{n}^{\mathrm{o}} 10.257 / 2001$ e definidas pelo decreto $\mathrm{n}^{\mathrm{o}}$ 5.790/2006, tendo como seus objetivos promover a interlocução entre autoridades e gestores públicos dos três entes federados com os diversos segmentos da sociedade acerca de assuntos relacionados à Política Nacional de Desenvolvimento Urbano e propiciar a participação popular.

As conferências nacionais foram realizadas em 2003, 2005, 2007, 2010 e 2013, com as etapas preparatórias em âmbito estadual e municipal. Por diversas vezes, veio a debate a questão federativa no desenvolvimento das cidades e a integração das políticas públicas.

\subsection{União}

A União vem ocupando há muito tempo papel essencial na política habitacional. Apesar de existirem experiências de governos estaduais e municipais, desde a República Velha, a União desenvolveu relevantes políticas habitacionais, com destaque para o BNH, que influencia até hoje a estruturação da política no país.

Um dos pontos mais relevantes para essa proeminência na atuação do governo federal são os recursos do FGTS e o papel de financiador desempenhado pela CEF, além 
da regulação da política de crédito. Apesar de existirem diversos modelos de política habitacional, a predominância do modelo baseado no financiamento é bastante presente na história dessa política pública no Brasil.

\subsubsection{Ministério das Cidades}

Além do papel de coordenação que a lei do SNHIS garante ao Ministério das Cidades, o decreto $n^{\circ} 5.796 / 2006$ lhe possibilitou uma competência relevante no sistema: a de "selecionar e definir critérios para seleção de propostas formuladas por Estados, Municípios e Distrito Federal." Isso significa que, ainda que as diretrizes sejam definidas pelo CGFNHIS, ainda que houvesse ampla participação da população num ambiente democrático, a decisão final é interna à burocracia do Ministério. As informações sobre os pedidos realizados e os pedidos atendidos com recursos, bem como a justificativa da decisão não são disponibilizadas eletronicamente, o que prejudica a transparência da seleção.

O Ministério das Cidades é o órgão gestor da aplicação do FGTS, tendo como uma de suas competências expedir atos normativos relativos à alocação dos recursos para implementação dos programas aprovados pelo CCFGTS, além de acompanhar a execução dos programas e definir metas. Nesse sentido, por meio de Instruções Normativas, como a $\mathrm{n}^{\mathrm{o}} 1 / 2011$, determina remanejamentos nos valores disponibilizados a cada ente federado e programa dos recursos do FGTS destinados à habitação popular ou, como a de nº 68/2009, que estabelece metas físicas e planos de contratações dos recursos do FGTS para o Programa Minha Casa, Minha Vida (PMCMV). As portarias também são utilizadas na determinação de programas, como a de $n^{\circ} 547 / 2011$, que dispõe sobre as diretrizes do PMCMV para Municípios com até 50.000 habitantes e a de $n^{\circ} 465 / 2011$ que autoriza a Secretaria Nacional de Habitação a remanejar as metas entre as unidades da federação para a alocação de recursos do Fundo de Arrendamento Residencial (FAR).

O funcionamento do Ministério foi descrito no relatório do TCU (2010, p. 283):

Do ponto de vista orçamentário, o órgão possui quatro linhas principais de atuação: (i) melhoria das condições de habitabilidade de assentamentos precários; (ii) construção de habitações de interesse social; (iii) subsídio à habitação de interesse social; e (iv) apoio à elaboração dos planos habitacionais de interesse social. No que concerne às ações não orçamentárias, as intervenções envolvem financiamentos junto aos setores públicos estadual, distrital e municipal, bem como ao setor privado (pessoas físicas e jurídicas). Nestes 
últimos, as ações estão estruturadas em quatro linhas de atuação: (i) financiamento à pessoa física para construção, reforma ou aquisição de imóvel novo ou usado (Carta de Crédito FGTS); (ii) financiamento à pessoa jurídica para construção habitacional (Apoio à Produção FGTS); (iii) financiamento imobiliário (Caderneta de Poupança/SBPE); e (iv) financiamento para aquisição de material de construção (Construcar/CEF).

O Ministério sofre com diversas limitações na sua operação, especialmente financeiras, sendo relevante destacar também a mudança de Ministro (saída de Olívio Dutra para a entrada de Márcio Fortes) e de partido (saída do Partido dos Trabalhadores para a entrada do Partido Progressista) em 2005, que foi apontada por muitos pesquisadores como um retrocesso na política habitacional (BONDUKI, 2009, p. 14):

Se mais não foi feito nessa área, é forçoso lembrar que o enfraquecimento e a desarticulação do Ministério das Cidades, particularmente da Secretaria Nacional de Programas Urbanos a partir de 2007, à qual cabe implementar políticas fundiárias e urbanas, têm um custo, a ser creditado na "política de governabilidade".

Podem ser observadas também dificuldades na execução dos contratos: no relatório da Controladoria Geral da União (CGU. SNH, 2008, p. 5) relativo ao ano de 2007, a Secretaria Nacional da Habitação estava com " $85,00 \%$ dos contratos de repasse com problemas de execução: obras/serviços não iniciadas, atrasadas e paralisadas."

\subsubsection{Banco Central}

O Banco Central (BC) é uma autarquia federal cujo presidente é membro do CMN, entre suas competências estão o controle do crédito e a fiscalização e regulação das instituições financeiras no país.

Diversas resoluções do Banco Central que publicizam decisões do CMN tratam da disponibilização de recursos captados em depósitos de poupança pelos agentes financeiros para a política habitacional como as de $n^{\circ} 3.005$, nº 3.177 e $n^{\circ} 3.259$ (FIX, 2011, p. 134):

[...] a Resolução do Banco Central n. 3.259 obrigou os bancos a aplicarem porcentagem do Sistema Brasileiro de Poupança e Empréstimo (SBPE) e do Fundo de Compensação das Variações Salariais (FCVS) em empréstimos imobiliários. Até então, parte dessa obrigatoriedade poderia ser atestada com a apresentação de créditos de antigos financiamentos imobiliários no âmbito do FCVS. Algumas normativas do Banco Central introduziram mudanças a partir de 2002, visando minimizar a utilização do FCVS virtual no cômputo da exigibilidade de direcionamento dos recursos do SBPE. 


\subsubsection{Ministérios da Fazenda, do Planejamento e Casa Civil}

Os três ministérios juntamente com o das Cidades compõe o Comitê de Acompanhamento do Programa Minha Casa, Minha Vida (CAPMCMV), instituído pelo decreto $n^{\circ}$ 6.962/2009. Além disso, os Ministérios da Fazenda, do Planejamento e das Cidades regulamentam o funcionamento do programa, determinando faixas de renda, valores das prestações, entre outras questões, por meio de portarias interministeriais.

\subsubsection{Caixa Econômica Federal}

A Caixa Econômica Federal (CEF), em sua configuração atual, foi criada pelo decreto-lei no 759/1969. É uma empresa pública, ou seja, faz parte da Administração Indireta, sendo vinculada ao Ministério da Fazenda, e, segundo o site da instituição ${ }^{61}$, a rede Caixa, incluindo correspondentes entre outros, está presente em todos os Municípios brasileiros ${ }^{62}$. Uma de suas finalidades é “operar no setor habitacional, como sociedade de crédito imobiliário e principal agente do Banco Nacional de Habitação, com o objetivo de facilitar e promover a aquisição de sua casa própria, especialmente pelas classes de menor renda da população” (art. 2º alínea 'c' do decreto-lei nº 759/1969).

Uma importante questão na organização institucional da política habitacional brasileira é o relevante papel ocupado pela Caixa Econômica Federal, que não faz parte da estrutura do Ministério das Cidades, como aborda Bonduki (2008, p. 97):

Apesar do avanço que representou a criação do Ministério, é necessário ressaltar que uma das suas debilidades é sua fraqueza institucional, uma vez que a Caixa Econômica Federal, agente operador e principal agente financeiro dos recursos do FGTS, é subordinada ao Ministério da Fazenda. Em tese, o Ministério das Cidades é o responsável pela gestão da política habitacional, mas, na prática, a enorme capilaridade e poder da Caixa, presente em todos os municípios do país, acaba fazendo que a decisão sobre a aprovação dos pedidos de financiamentos e acompanhamento dos empreendimentos seja sua responsabilidade.

\footnotetext{
61،A Rede CAIXA está presente em todos os municípios brasileiros.” Disponível em: <http://www1.caixa.gov.br/atendimento/canais_atendimento/agencia.asp?TipoParametro=agencia_sem_penh or>. Acesso em 20.07.2013.

${ }^{62}$ São realizadas aproximações entre a Caixa e os Municípios. Em 2008, por exemplo, foram realizadas 4.200 visitas a Municípios (CEF, 2008).
} 
A CEF é o agente operador do FGTS, definindo os procedimentos para a execução dos programas de habitação popular e elaborando a análise jurídica e econômico-financeira dos projetos. A empresa também é responsável pela operacionalização da gestão do Fundo de Arrendamento Residencial, destinado ao PMCMV voltado à população de renda mais baixa, e do Fundo de Desenvolvimento Social (FDS) destinado ao Programa Crédito Solidário e ao PMCMV-Entidades, além de administrar o Fundo Garantidor da Habitação Popular (FGHab).

Em alguns casos, a escolha dos beneficiados é feita diretamente pela Caixa (IPEA, 2011b, p. 24):

No âmbito das Resoluções $n^{\circ} 460$ e $n^{\circ} 518$, do Conselho Curador do Fundo de Garantia do Tempo de Serviço (CCFGTS), que modificou a primeira, não há processo de seleção de propostas conduzido pelo MCidades. Assim, as superintendências regionais da CAIXA são responsáveis pela alocação dos subsídios, a partir de dotação recebida periodicamente.

Esse protagonismo também se deve à capilaridade e à capacidade da Caixa na política habitacional (CGU. CEF, 2008, p. 5): “Tendo em vista as limitações operacionais do Ministério das Cidades, a necessidade de utilização dos serviços da CAIXA se torna fundamental para a execução dos empreendimentos."

A política habitacional no Brasil ainda é muito ligada a uma ideia de fornecimento de financiamento habitacional e, atualmente, a Caixa Econômica Federal é o principal ator desse segmento no país. Nesse caso, a preponderância da União não é ligada apenas a uma competência constitucional determinada, mas ao modelo da política pública e ao ator que a realiza no país atualmente.

No SNHIS, a Caixa desempenha o papel de agente operador, é a instituição depositária dos recursos do fundo, sendo responsável por "analisar a viabilidade das propostas selecionadas pelo Ministério das Cidades" (art. $7^{\circ}$, inc. VI do decreto $\mathrm{n}^{\mathrm{o}}$ 5.796/2006). Desse modo, mais uma vez um órgão integrante do governo federal tem a possibilidade de rejeitar propostas de atendimento habitacional segundo critérios próprios.

No PMCMV, a Caixa seleciona os projetos dentro da modalidade FAR, realiza análise de risco, jurídica e de engenharia, aprova por meio do comitê regional e contrata por meio da agência, segundo Cardoso et al. (2013). No Programa MCMV-Entidades a Caixa envia os projetos analisados para o MCidades e depois os contrata. Nos financiamentos com recursos do FGTS dentro do programa, a Caixa avalia os lançamentos, 
sendo que o comitê regional ou a matriz decide e contrata. Por fim, na modalidade de oferta pública de recursos, a Caixa seleciona os agentes financeiros privados.

\subsection{Estados}

O fim do Banco Nacional de Habitação deixou um vazio institucional, tendo a política habitacional sido realizada por alguns Estados e por outros não.

O Estado de São Paulo, por exemplo, estabeleceu a vinculação de uma porcentagem do ICMS à habitação, o que contribuiu para a institucionalização de uma política estadual (ARRETCHE, 2000). É claro que o desenvolvimento de uma política estadual de habitação não dependeu apenas desse fator, já que a existência de uma burocracia especializada e da priorização da questão nos governos da época - ainda que por interesses empresariais também contribuíram para a criação de um sistema independente do governo federal.

Em São Paulo, a assunção do papel de provedor de políticas públicas de habitação já havia sido feita antes mesmo da criação do BNH, segundo Arretche (2000, p. 108):

Em 1949, foi criada a CECAP (Caixa Estadual de Casas para o Povo), então uma autarquia ligada à Secretaria do Trabalho. Na prática, contudo, esta agência somente começou a ter uma atuação efetiva no campo da produção habitacional a partir de 1967. A CECAP a ele se integrou como agente promotor, seja operando com recursos no âmbito do SBPE, seja operando com recursos do FGTS, emprestados ao BNH. Em 1975, a CECAP transformou-se em empresa de economia mista, passando a chamar-se CODESPAULO; finalmente, em 1982 foi criada a $\mathrm{CDH}$, que, em 1989, passou a chamar-se CDHU.

O modelo predominante da CDHU envolvia a participação dos Municípios (FIX, 2011, p. 115):

A maior quantidade de unidades habitacionais foi produzida no programa SH3. As prefeituras deveriam solicitar a construção dos conjuntos. Se aprovada, deveriam doar a terra, selecionar as famílias, prover a infraestrutura e os equipamentos sociais, habilitar as famílias junto ao programa e entregar as chaves. O projeto, a produção do conjunto e a comercialização ficavam a cargo da CDHU. Para as construções, a Companhia promovia licitações dentro da modalidade chamada Empreitada Global.

Mesmo a CDHU, fruto de uma descentralização, passou por um processo de descentralização com a criação de escritórios regionais; para aumentar a produção de unidades, tornou-se, predominantemente, uma gerenciadora de construtoras (ROYER, 2002). É interessante notar que, apesar da autonomia da política habitacional do Estado de 
São Paulo, ela carrega os mesmos problemas e limitações do modelo centralizado do BNH (ROYER, 2002, p. 180):

Todas as críticas apresentadas ao modelo do regime autoritário podem ser opostas à política habitacional estruturada pelo Estado: produção em massa, fazendo do número de unidades o critério de mensuração da eficiência da política; tratamento mercantil da questão habitacional, oferecendo poucas alternativas para os setores de menor renda; apropriação privada do fundo público pelas empreiteiras, que passam a viver do orçamento estatal; separação da questão habitacional da questão urbana, destacando a moradia dos outros problemas da cidade; apropriação simbólica do discurso, fazendo da nunca realizada universalização do direito um meio de legitimação do governo e cooptação política de movimentos organizados e prefeituras do interior. A reiteração dos equívocos do modelo anterior dão a clareza da filiação da política da CDHU, de modo que, mesmo com a desarticulação do sistema e com o novo pacto federativo, esta continuou operando como um agente do $\mathrm{BNH}$, produtor de unidades habitacionais.

Esse processo de assunção da política pelos Estados foi bastante heterogêneo ${ }^{63}$, sendo muito limitado em diversos deles, em grande parte devido à falta de uma política de descentralização do governo central, que tinha interesse em continuar condicionando a obtenção de recursos a negociações políticas (ARRETCHE, 2000, p. 124): "a orientação do Executivo federal foi de manter um sistema centralizado, gerido por uma burocracia fragilmente insulada."

O FNHIS, criado em 2005, conta com transferências de recursos aos Estados: voluntárias, vinculadas a um fim, impondo condições e tendo como objetivo dar coerência a uma política nacional de habitação. Os recursos são repassados por meio dos fundos dos entes subnacionais, eles têm liberdade para determinar 3/4 da composição do seu conselho gestor e elaborar seu plano de habitação de interesse social, desde que este esteja de acordo com o plano e a política nacional e com o plano diretor do Município onde os recursos serão aplicados. As diretrizes mais gerais são dadas pelos editais de seleção de propostas, mas o escopo do projeto, desde que adequado a essas diretrizes e às determinações legais, é definido pelos Estados.

A lei que criou o SNHIS buscou destacar o papel articulador que os Estados devem ter no âmbito de seu território, com a integração dos planos locais com os planos de

\footnotetext{
${ }^{63}$ A heterogeneidade da atuação dos Estados continua: vide GONÇALVES, Renata da Rocha. Políticas Habitacionais na Federação Brasileira: os estados em busca de seu lugar. Dissertação de Mestrado. Escola de Administração de Empresas de São Paulo. Fundação Getúlio Vargas. São Paulo, 2009.
} 
desenvolvimento regional, a coordenação de intervenções intermunicipais e a oferta de apoio dos Estados aos Municípios para que eles desenvolvam seus programas habitacionais, além da possibilidade da criação de fundos e conselhos regionais, que ainda não existem. ${ }^{64}$

No entanto, os recursos podem ser acessados por Municípios e entidades não governamentais diretamente do fundo nacional, o que pode limitar o papel coordenador dos Estados e reforçar a predominância já existente de acordos dos Municípios com a União, conforme análise feita nos Municípios que realizaram programas de construção de unidades habitacionais em 2010-2011 (IBGE, 2011a): 76,14\% deles o fizeram em parceria com a União, enquanto $64,52 \%$ com os Estados e 19,78\% por iniciativa exclusiva dos Municípios. A participação da União e dos Estados nos programas de construção subiu: em 2007/2008 era de 67,78\%, dos Estados era de 51,11\% e de iniciativa exclusiva da prefeitura 21,91\% (IBGE, 2008). Apenas quatro Estados apresentaram mais participação que a União nos programas de construção: Acre, Espírito Santo, Mato Grosso do Sul e São Paulo (IBGE, 2011a). Em 2008 eram Paraná, São Paulo, Mato Grosso e Goiás (IBGE, 2008).

As parcerias dos Municípios com as esferas estadual e federal variam de acordo com os programas: no caso de programas de melhorias de unidades habitacionais, as iniciativas exclusivas das prefeituras superam as parcerias federativas: 63,17\%, sendo 19,04\% com os Estados e 31,54\% com a União (IBGE, 2011a). Mesma situação da oferta de material de construção: 89,6\% exclusivo das prefeituras, e cerca de 7\% com Estados e União (IBGE, 2011a). Infelizmente, no âmbito deste trabalho não é possível destacar toda a produção independente dos entes federados: Estados e Municípios desempenham políticas públicas de iniciativa exclusiva ou em parceria, sem a participação da União.

Dentro de programas como Minha Casa, Minha Vida, o papel dos entes federados é bastante limitado: no âmbito do FAR, por exemplo, cabe a eles selecionarem candidatos, realizarem trabalho social após a intervenção e oferecerem contrapartidas.

\subsection{Municípios}

\footnotetext{
${ }^{64}$ Apesar da previsão legal para sua criação, os fundos e conselhos regionais não foram instituídos até o momento, segundo a CEF em resposta a pedido de informação da autora.
} 
Nos últimos anos, tem aumentado o valor total das transferências de recursos financeiros para os Municípios, bem como têm sido descentralizadas algumas políticas como a educação fundamental (AFONSO, 2006, p. 8):

Numa perspectiva de mais longo prazo, comparando as últimas quatro décadas e meia, é verificado que não apenas o governo central perdeu importância relativa, como também a esfera estadual (que tinha um peso relativo em 2004 inferiores aos de 1988, antes de implantado o atual sistema). Quem apresenta uma tendência clara e consistente de ampliação de importância relativa na federação brasileira são os governos municipais.

No entanto, o papel dos Municípios nas políticas públicas ainda é bastante indeterminado e heterogêneo, o que também é resultado do desenho de 1988, no qual houve pouca determinação na divisão dos encargos. Cabe a outros arranjos legais e infralegais possibilitar o equilíbrio entre receitas e encargos, essencial para políticas estruturadas: estabelecer quem financia, quem executa, quem controla.

Os Municípios desempenham, ou deveriam desempenhar, um papel bastante importante nas políticas habitacionais, especialmente porque elas dependem diretamente do ordenamento do território e de outras políticas públicas de infraestrutura urbana de sua competência como saneamento, iluminação pública, transporte público e asfaltamento (SAULE JR., 1997, p. 72):

O município, com base no artigo 182 e no princípio da predominância do interesse, é o principal ente federativo responsável por promover a política urbana de modo a ordenar o pleno desenvolvimento das funções sociais da cidade, de garantir o bem-estar de seus habitantes e de garantir que a propriedade urbana cumpra sua função social, de acordo com os critérios e instrumentos estabelecidos no plano diretor, definido constitucionalmente como instrumento básico da política urbana.

As políticas habitacionais e as políticas públicas de competência municipal devem ser articuladas como modo de evitar: tanto a subutilização de infraestrutura já existente, quanto a construção de unidades habitacionais desvinculadas da infraestrutura urbana e dos serviços públicos, que são inadequadas e podem elevar os custos de manutenção e expansão destes, uma das críticas feitas ao Programa Minha Casa Minha Vida como aponta Maricato (2011, p. 67): “[...] o PMCMV retoma a política habitacional com interesse apenas na quantidade de moradias, e não na sua fundamental condição urbana.”

Nos Municípios, a falta de autonomia da questão habitacional pode ser verificada na organização administrativa: segundo dados da pesquisa Munic (IBGE, 2011a), 62,5\% das áreas de habitação nos Municípios são subordinadas a outros órgãos, em 19,4\% a 
secretaria é em conjunto com outras políticas, em $6,1 \%$ a secretaria é exclusiva, em $11 \%$ é um setor subordinado à chefia do Executivo e em $1 \%$ é órgão da administração indireta. Apenas em Municípios com mais de 500.000 habitantes a presença de secretarias exclusivas $(48,6 \%)$ é superior a de setores subordinados $(8,1 \%)$.

É importante destacar também que o gasto em habitação e urbanismo pelos Municípios brasileiros é bastante desigual. Comparando políticas reguladas ${ }^{65}$ e políticas não reguladas (como habitação e transporte público) numa série histórica de 1996 a 2006, Marta Arretche (2012, p. 197) conclui que nas políticas não reguladas a desigualdade ${ }^{66}$ nos gastos entre Municípios é muito maior:

O Coeficiente de Gini na função "habitação e urbanismo" já era alto $(0,474)$ e se mantém bastante estável ao longo da série. Em 2006, o Coeficiente de Gini dessa função era de 0,432. [...] Em suma, há um claro padrão de desigualdade de gasto entre as políticas implementadas pelos municípios brasileiros.

Mesmo com limitações, 84,6\% dos Municípios declararam desenvolver alguma política habitacional, sendo que a porcentagem cresce de acordo com o tamanho da população, atingindo 97,4\% do total de Municípios acima de 500.000 habitantes (IBGE, 2011a). A associação dos Municípios com os governos estaduais e federais varia de acordo com a modalidade de política habitacional oferecida. No caso de programas de regularização fundiária, 20,9\% dos Municípios realizam-nos em conjunto com o governo federal, $37,9 \%$ com o governo estadual e 54,4\% por iniciativa exclusiva. Já na oferta de unidades habitacionais a participação do governo federal cresce para 76,1\% e as políticas de iniciativa exclusiva passam a representar 19,8\% do total (IBGE, 2011a).

\subsection{Atores não estatais}

A construção do espaço não é realizada apenas por atores estatais, mas é fruto da sociedade como um todo (SOUZA, 2005, p. 99): “O espaço social é ao mesmo tempo um produto das relações sociais e um condicionador dessas mesmas relações."

\footnotetext{
${ }^{65}$ Com limitações à autonomia dos Municípios e um mínimo de gasto instituído legalmente: saúde e educação.

${ }^{66}$ A desigualdade foi calculada com o Coeficiente de Gini para os gastos municipais em cada função. O Coeficiente de Gini mede a distribuição da desigualdade variando de 0 (igualdade total) a 1 (desigualdade total).
} 
Diversos atores constroem o espaço e as políticas habitacionais influenciam e são influenciadas por esse processo. Mais recentemente, o espaço tem sido cada vez mais inserido no circuito de circulação do capital financeiro (BOTELHO, 2007), incorporando novos atores e dinâmicas às políticas.

Os atores privados participam das políticas públicas todo o tempo: na formação das agendas, na formulação, na implementação, na avaliação e no monitoramento. Esses atores são diversos: de movimentos populares de luta por moradia a grupos empresariais com grande poder econômico. Apesar de a dissertação tratar dos arranjos dentro da federação, ignorar a participação dos atores privados seria reduzir muito a análise, então, mesmo que superficialmente, eles serão mencionados.

\subsubsection{Empresas da construção civil}

Mesmos as empresas que não participam da política habitacional voltada à população de baixa renda, influenciam essa política (AGUIAR, 2008, p. 31):

A organização interna das cidades é comandada em grande parte pelas ações de agentes particulares que realizam empreendimentos, determinam a seleção de áreas, definem a produção de novos padrões de moradia para os setores de renda mais elevada, além de induzirem investimentos públicos, que por sua vez reforçam e reiteram o processo de diferenciação espacial.

A relevância dessas empresas pode ser observada de forma clara na construção do Programa Minha Casa, Minha Vida, no contexto da crise do setor (DIAS, 2012, p. 133):

A proposta por construção de moradias via FNHIS perde força, em razão do caráter emergencial da crise e também de todos os problemas operacionais relacionados à operação desse fundo. O Planalto passa a articular um plano diretamente com as principais construtoras do país e a $\mathrm{CBIC}^{67}$, que representa as médias e pequenas construtoras em nível nacional. Nesse sentido, a Presidência da República toma para si a liderança da proposta de construção de moradias e ultrapassa a Campanha Nacional pela Moradia Digna, esvaziando-a na perspectiva imediata de alocação de recursos.

A participação de empresários na formulação do programa não ficou oculta, mas é declarada publicamente, como, por exemplo, no site do Sinduscon de São Paulo (Sindicato da Indústria da Construção Civil do Estado de São Paulo) (2012):

\footnotetext{
${ }^{67}$ A CBIC é a Câmara Brasileira da Indústria da Construção e reúne 68 sindicatos e associações do setor em todos os Estados. Disponível em: 〈http://www.cbic.org.br/institucional〉._Acesso em 20.07.2013.
} 
O sindicato mobilizou-se e, junto com outras entidades do setor, obteve do governo um programa anticíclico, iniciado com linhas de crédito específicas e que culminou no lançamento do programa habitacional Minha Casa, Minha Vida, em março de 2009. A partir de então, a construção recuperou-se e voltou a crescer.

As empresas do setor da construção civil podem desempenhar o papel de construtoras, de incorporadoras ou os dois papéis alternativa ou cumulativamente, em função do empreendimento.

O desenho do PMCMV deixa clara a priorização do setor empresarial (BUONFIGLIO, DANTAS, 2011, p. 8):

O poder do mercado imobiliário na definição de políticas habitacionais extrapola o controle público do Estado e dos Conselhos Setoriais. No MCMV, observa-se o papel determinante desempenhado pelas construtoras e incorporadoras alavancadas pela financeirização imobiliária. Estes agentes estão definindo não apenas a localização e o público alvo, mas os projetos, tipologias e qualidade das edificações.

É relevante destacar também que empresas do setor estão ligadas a doações para campanhas eleitorais e influenciam os governos em diversas esferas. Por exemplo, nas eleições de 2012 no Município de Dracena (Município do Oeste Paulista que, segundo o Censo 2010, contava com 43.258 habitantes), na campanha para a reeleição do prefeito Célio Rejani (PV) constatou-se que de um total de doações de $\mathrm{R} \$ 209.430,00$, havia doações de: $\mathrm{R} \$ 500,00$ de uma empresa de corretagem de imóveis, $\mathrm{R} \$ 2.200,00$ de duas empresas de construção de edifícios e $\mathrm{R} \$ 22.400,00$ de três empresas de incorporação de empreendimentos imobiliários. ${ }^{68}$ Para o candidato vitorioso José Antônio Pedretti (PR), com uma campanha mais modesta de $\mathrm{R} \$ 72.659,54$, consta a doação de $\mathrm{R} \$ 3.000,00$ de uma empresa de incorporação de empreendimentos imobiliários. ${ }^{69}$

No Município de São Paulo, a questão veio à tona depois de decisões judiciais que cassavam o mandato do prefeito e de vereadores (FOLHA DE SÃO PAULO, 2010) por conta de doações ilegais recebidas por meio da Associação Imobiliária Brasileira, que foi

\footnotetext{
${ }^{68}$ Também foram doados $\mathrm{R} \$ 3.000,00$ de uma empresa que, apesar de não ter como objeto a incorporação imobiliária é do mesmo grupo de outra empresa que realiza tal atividade: Coimma. A pesquisa foi realizada por meio de consultas ao objeto social das doadoras de campanha que constam na prestação de contas do Tribunal Superior Eleitoral: <http://inter01.tse.jus.br/spceweb.consulta.receitasdespesas2012/abrirTelaReceitaComite.action>. Consulta ao objeto social: 〈https://www.jucesponline.sp.gov.br/pesquisa.aspx $>$. Acesso em 20.06.2013.

${ }^{69}$ Nesse caso a empresa Coimma também realizou uma doação no valor de $\mathrm{R} \$ 2.000,00$. Consta também uma doação de R $\$ 1.762,00$ do diretório estadual, que é composto por, entre outras doações, valores direcionados por empresas ligadas ao ramo da engenharia como a Provence Construtora Ltda.
} 
utilizada para esconder as doações do Sindicato das Empresas de Compra, Venda, Locação e Administração de Imóveis Residenciais e Comerciais (Secovi) de São Paulo, já que doações de sindicatos são proibidas. Não se quer aqui comparar a relevância econômica e o impacto das doações nos dois Municípios, mas apenas ilustrar que a presença de empresários do setor se faz presente em diversos níveis de governo e de diversas maneiras, influenciando as políticas públicas.

No caso do PMCMV, as empresas têm grande relevância por serem as responsáveis por apresentar projetos e executá-los no âmbito do Fundo de Arrendamento Residencial, conforme a portaria no 168/2013 do Ministério das Cidades: “a) apresentar às instituições financeiras oficiais federais projetos de produção de empreendimentos para alienação dos imóveis; b) executar os projetos contratados pela instituição financeira oficial federal; e c) realizar a guarda dos imóveis pelo prazo de sessenta dias após a conclusão e legalização das unidades habitacionais."

A escolha do terreno, o projeto e a construção são realizados pelos agentes privados, deixando o papel dos agentes públicos em segundo plano: tanto pela inexistência de produção pública no programa, quanto pelo desprezo ao planejamento e à regulação dos entes federados em seus territórios.

O setor da construção civil é beneficiário de diversas renúncias fiscais (Cardoso, 2013). Recentemente, sofreu mudanças em virtude da abertura de capital na bolsa de valores de algumas das mais importantes empresas, o que, juntamente com o aumento do crédito e com a expansão das faixas de renda em que elas atuam, contribuiu para o aumento de unidades construídas após 2006, como aponta Lúcia Shimbo (2010, p. 135):

Seja pela entrada de recursos proveninentes de financiamento habitacional, pela institucionalização de novos marcos regulatórios que favoreceram a incorporação privada, pela injeção de recursos de investidores estrangeiros, pela tendência de crescimento e de concentração de capital no setor imobiliário, a atuação das empresas construtoras e incorporadores de capital aberto foi potencializada vertigionosamente, a partir de 2006.

A autora também aborda a confusão intencional entre habitação social e de mercado como forma de ampliar o acesso e o desvio dos recursos públicos e semipúblicos destinados à população de renda mais baixa, o que prejudica o controle sobre os recursos que mudarão as cidades (SHIMBO, 2010).

\subsubsection{Instituições financeiras}


A construção do espaço é um processo dinâmico, produto da ação de diversos atores, impactando nas políticas habitacionais. Nesse sentido, também é relevante destacar o papel das instituições de crédito que, individualmente ou organizadas em associações como a Associação Brasileira das Entidades de Credito Imobiliário e Poupança (Abecip), influenciam na formulação e execução de políticas.

Também merecem breve menção os organismos internacionais como o Banco Mundial e o Banco Interamericano de Desenvolvimento (BID) que realizam empréstimos aos governos locais sob condicionantes que influenciam a definição das políticas urbanas e habitacionais, restringindo e moldando o desenho das políticas públicas, conforme aborda Arantes (2006): parcerias público-privadas, políticas habitacionais e urbanas baseadas na 'recuperação plena de custos' e não na necessidade da população, investimento em áreas de interesse do mercado, terceirização da gestão estatal, ocultação dos conflitos em torno das escolhas de políticas entre outras consequências.

Na modalidade Oferta Pública de Recursos (OPR) do PMCMV para Municípios até 50.000 habitantes (portaria interministerial $n^{\circ} 484 / 2009$, Ministérios da Fazenda e das Cidades), as instituições e agentes financeiros analisam as condições de elegibilidade e viabilidade técnica, jurídica e documental das demandas indicadas pelos entes federados, depois da seleção realizada pelo MCidades, e acompanham a execução dos empreendimentos.

\subsubsection{Movimentos populares}

Diversos movimentos que lutam pelo direito à moradia e à cidade têm presença constante nos debates, conferências, conselhos e manifestações que visam influenciar as políticas habitacionais. Especialmente durante as décadas de 1980 e 1990 surgem diversos movimentos como cita Rodrigues (2013, p. 24): "nascem a Confederação Nacional de Associação de Moradores (Conam), em 1984; Movimento Nacional de Luta por Moradia (MNLM), formado em 1990; União Nacional por Moradia Popular (UNMP), em 1993; e a Central de Movimentos Populares, em 1997."

Alguns deles estão organizados no Fórum Nacional de Reforma Urbana juntamente com outros atores (MARICATO, SANTOS JR., 2006, p. 4):

O Fórum é uma coalizão de organizações que reúne movimentos populares, organizações não-governamentais, associações de classe, e instituições 
acadêmicas e de pesquisa em torno da defesa da reforma urbana, da gestão democrática e da promoção do direito à cidade.

Alguns movimentos se organizam para desempenhar o papel de promotores de empreendimentos habitacionais por meio de linhas de financiamento específicas. A partir da lei $\mathrm{n}^{\circ} 11.578 / 2007$, as entidades sem fins lucrativos passaram a poder disputar recursos no SNHIS. Segundo a resolução no 18 do CGFNHIS, é atribuição das entidades selecionar os beneficiários finais, observados os critérios normativos, apresentar a proposta e gerenciar a obra.

Portarias do Ministério das Cidades, como as de $n^{\circ} 105 / 2012, n^{\circ} 107 / 2013, n^{\circ}$

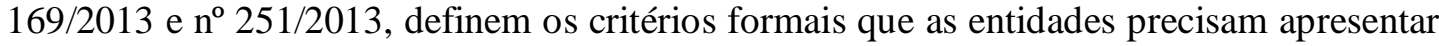
para poder participar de programas de habitação de interesse social geridos pelo ministério, a abrangência que podem alcançar e estabelece uma pontuação que determina o número de unidades que elas podem executar simultaneamente de acordo com participação em conferências e conselhos, experiências anteriores na produção de unidades habitacionais, capacitação dos membros, desenvolvimento de atividades de participação. Desse modo, o governo centraliza o cadastro das entidades em todo o território nacional e induz a estrutura e os requisitos que considera necessários às entidades que desejem executar unidades habitacionais com recursos federais.

Entre as entidades que apresentaram documentação no período de 10 a 12 de junho de 2013, 10 foram habilitadas e 68 não. A deficiência mais frequente foi a ausência de cópia do estatuto social atualizado e registrado, problema de 54 entidades. ${ }^{70}$ Em 2013, 1.039 entidades estavam cadastradas.

Uma linha de financiamento disponível a essas entidades é o Programa Minha Casa, Minha Vida-Entidades (PMCMV-E), que foi criado pela resolução no 183/2011 ad referendum do CCFDS. O programa sofre críticas porque seu formato é voltado para construtoras e mal adaptado para as entidades, com disputas por terras com agentes do mercado e financiamentos individualizados (Evaniza L. Rodrigues, 2013). Dentro do PMCMV, o Programa Nacional de Habitação Rural pode ser efetivado por entidades sem fins lucrativos ou pelos entes federados. Também é possível a utilização da Carta de Crédito Associativo com recursos do FGTS, que tem tido seus recursos diminuídos em favor da ação de Apoio à Produção, priorizada após a criação do PMCMV (FGTS, 2012).

\footnotetext{
${ }^{70}$ Consulta ao site do Ministério das Cidades: Disponível em: <http://www.cidades.gov.br/images/stories/ArquivosSNH/ArquivosPDF/Publicacoes/Resultado_da_anlise_d a_habilitao_-_entidades_que_pleitearam_entre_10.06_e_12.06.13.pdf $>$. Acesso em 25.08.2013.
} 


\subsubsection{Outros atores}

Não é possível enumerar todos os atores que influenciam a política habitacional e constroem o espaço. Cabe mencionar a atuação do Sindicato das Empresas de Compra, Venda, Locação e Administração de Imóveis Residenciais e Comerciais (Secovi), da Federação das Indústrias do Estado de São Paulo (Fiesp), da Federação das Indústrias do Estado do Rio de Janeiro (Firjan), das universidades, das companhias de habitação, das cooperativas, dos sindicatos e entidades como o Instituto dos Arquitetos do Brasil (IAB), das assessorias técnicas de projetos autogestionados entre outros.

É relevante também a pressão dos proprietários de terras, ainda que não estejam organizados de forma permanente, conforme aponta José Roberto Bassul (2005, p. 141):

A produção habitacional no Brasil, em grande parte, não se destina a atender à demanda efetiva de moradias, mas a produzir um ativo financeiro. E o mercado interessado na valorização desse ativo não é obviamente formado apenas pelos seus produtores, mas igualmente pelos compradores/investidores. Em outros termos, resistências dessa natureza associam proprietários, grandes e pequenos, e empreendedores contra a efetiva implementação de dispositivos que, por levarem a uma maior oferta, possam constituir ameaça às altas taxas médias de rentabilidade desse tipo de investimento.

Outros atores empresariais também têm algum relevância no desenho das políticas como as empresas de consultoria. São empresas que prestam serviços aos governos, normalmente com estudos e elaboração de planos para a formulação de políticas públicas. Pesquisa realizada pelo Ministério das Cidades (2006) a respeito do plano diretor em alguns Municípios de regiões metropolitanas constatou que dos 274 dos Municípios que responderam ao questionário: 204 terceirizaram a confecção dos seus planos. 


\section{Capitulo 4: ESTRUTURA FEDERATIVA DO SNHIS}

\section{Sistema Nacional de Habitação de Interesse Social}

A lei que criou o Sistema Nacional de Habitação de Interesse Social, $\mathrm{n}^{\circ}$ $11.124 / 2005$, e o decreto que a regulamentou, $\mathrm{n}^{\mathrm{o}} 5.796 / 2006$, tiveram como finalidade coordenar todos os entes federados e outros atores envolvidos na política pública de habitação para população de baixa renda, tendo como um de seus objetivos "articular, compatibilizar, acompanhar e apoiar a atuação das instituições e órgãos que desempenham funções no setor da habitação" e como um de seus princípios "compatibilidade e integração das políticas habitacionais federal, estadual, do Distrito Federal e municipal, bem como das demais políticas setoriais de desenvolvimento urbano, ambientais e de inclusão social."

Segundo o art. 12 da lei $\mathrm{n}^{\circ} 11.124 / 05$, os recursos do FNHIS devem ser aplicados de forma descentralizada por intermédio dos Estados, Distrito Federal e Municípios que precisam: constituir fundo com dotação orçamentária própria, constituir conselho com pelo menos $1 / 4$ das vagas destinadas aos representantes dos movimentos populares, apresentar Plano Habitacional de Interesse Social, aderir ao sistema, elaborar relatórios de gestão, observar os parâmetros e diretrizes para a concessão dos subsídios e oferecer contrapartidas, que podem ser em recursos financeiros, bens imóveis urbanos ou serviços.

Depois da adesão e do cumprimento das condicionantes mencionadas, os entes devem apresentar projetos que estejam de acordo com os programas existentes, ou seja, a aplicação do dinheiro do FNHIS é vinculada aos fins determinados de maneira centralizada. A adesão dos Estados e Municípios é voluntária e segundo os dados do comunicado do IPEA $\mathrm{n}^{\mathrm{o}} 118$ (2011) elaborados a partir dos dados da CAIXA e do MCidades/SNH/Departamento de Desenvolvimento Institucional e Cooperação Técnica (DICT) atualizados até 28.jun.2011, aderiram todos os Estados e 5.377 Municípios, ou seja, $96,7 \%$ do total.

A seleção das propostas depende da disponibilidade orçamentária do fundo: em 2009, por exemplo, foram aprovadas 580 propostas das 6.827 apresentadas nas ações Planos Habitacionais, Urbanização e Produção Social da Moradia (MCIDADES, 2010, p. 26), ou seja, cerca de $8,5 \%$ de aprovação. 


\section{Limites do sistema}

O desenho institucional do sistema, seu funcionamento, bem como as contrapartidas exigidas dos entes federados representam limites na coordenação das políticas públicas habitacionais.

\subsection{Composição do CGFNHIS}

A composição do Conselho Gestor do FNHIS, integrado de forma paritária por órgãos do Poder Executivo Federal e representantes da sociedade civil, não foi definida por lei, mas pelo decreto $\mathrm{n}^{\circ} 5.796 / 2006$, o que lhe traz fragilidade institucional, dependendo apenas da vontade do Executivo federal para sua modificação a qualquer tempo. No decreto foi limitada a participação dos Executivos de outros entes federados, possibilidade que estava aberta no texto da lei. ${ }^{71}$

Antes da publicação do decreto que instituiu a composição dos membros do CGFNHIS, o Conselho das Cidades, preocupado com a construção plena do SNHIS e com o pacto federativo, já havia recomendado a presença de representantes do Poder Executivo estadual e municipal por meio da resolução recomendada $n^{0} 5 / 2006$, o que não foi considerado no formato final: dez representantes do Poder Executivo federal, um representante do Poder Executivo estadual, um representante do Poder Executivo municipal, quatro representantes dos movimentos sociais, três representantes das entidades empresariais, três representantes das entidades de trabalhadores, um representante de organizações não governamentais e um representante de entidades profissionais, acadêmicas e de pesquisa.

A composição do Conselho ficou assim estabelecida pelo decreto: Ministro de Estado das Cidades, Secretário Nacional de Habitação, um representante do Ministério da Ciência e Tecnologia, um representante do Ministério da Cultura, um representante do Ministério do Desenvolvimento Social e Combate à Fome, um representante do Ministério da Fazenda, um representante do Ministério da Integração Nacional, um representante do Ministério do Meio Ambiente, um representante do Ministério do Planejamento, Orçamento e Gestão, um representante do Ministério da Saúde, um representante do Ministério do Trabalho e Emprego, um representante da Caixa Econômica Federal, quatro

\footnotetext{
${ }^{71}$ A lei não possibilitou a inclusão de representantes dos outros Poderes.
} 
representantes de entidades da área dos movimentos populares, três representantes de entidades da área empresarial, três representantes de entidades da área de trabalhadores, um representante de entidade da área profissional, acadêmica ou de pesquisa e um representante de organização não governamental.

Apesar de a legislação impor aos entes federados que $25 \%$ dos membros de seus conselhos sejam de movimentos populares, a porcentagem no CGFNHIS é de 16,6\% de seus membros, ou seja, o modelo a ser seguido não é utilizado no conselho do fundo nacional.

O decreto determina que o presidente do Conselho Gestor do FNHIS possa convidar para participar das reuniões do Conselho até dois representantes do Poder Público Estadual, do Distrito Federal ou de entidades civis de representação do Poder Público Estadual e do Distrito Federal e do Poder Público Municipal ou de entidades civis de representação do Poder Público Municipal, mas eles não têm direito a voto.

Importante destacar que o Ministro das Cidades é o presidente do conselho, detendo o voto de qualidade, sendo possível ainda tomar decisões ad referendum do conselho.

\subsection{Diretrizes e destinação dos recursos}

De modo geral, todas as diretrizes para os investimentos, bem como a destinação dos recursos do fundo são determinados em nível federal. Os Municípios e Estados que contarem com alguma capacidade técnica desenvolverão projetos com um grau de autonomia bastante limitado pelas escolhas do governo federal, por meio do Ministério das Cidades, da CEF e do CGFNHIS.

Os projetos são selecionados pelo governo central, que conta aí com mais uma oportunidade para direcionar os programas habitacionais aos seus objetivos. Além de obrigar os Estados e Municípios a desenvolverem uma estrutura institucional padronizada na área habitacional, o desenho do SNHIS condiciona as políticas públicas estaduais e municipais às escolhas do governo federal.

Segundo o decreto $\mathrm{n}^{\circ}$ 5.796/2006, cabe ao Ministério das Cidades "selecionar e definir critérios para seleção de propostas formuladas por Estados, Municípios e Distrito Federal.” O que, na prática, significa que a decisão, em última instância, é do Ministro das Cidades. O modelo desenvolvido prioriza esse ator, já que além de deter o voto de qualidade na instância que define as diretrizes (CGFNHIS), também cabe a ele decidir quais projetos serão beneficiados com recursos do fundo. Após essa seleção feita pelo 
ministério, ainda há uma análise de viabilidade feita pela CEF (art. $7^{\circ}$, VI do decreto $\mathrm{n}^{\circ}$ 5.796/2006), destacando mais uma vez o papel do governo central.

Desde sua criação até março de 2013, o CGFNHIS havia publicado 53 resoluções, sendo que destas nove são decisões do ministro e nove são referendos do conselho a essas decisões. O ministro se utilizou bastante da possibilidade trazida pelo inciso XI do art. $8^{\circ}$ da resolução $\mathrm{n}^{\circ} 1$ - regimento interno - para deliberar sobre matérias consideradas relevantes e urgentes.

Apesar da destinação dos recursos estar dividida entre modalidades de ações e distribuição territorial, o Ministério das Cidades realiza a seleção e pode distribuir de maneira diversa da determinada pelo CGFNHIS: segundo o $\S 2^{\circ}$ do $\operatorname{art.~} 3^{\circ}$ da resolução $n^{\circ}$ 27/2009 é "facultado ao Ministério das Cidades promover remanejamento de recursos entre as propostas integrantes da ação de Melhoria das Condições de Habitabilidade de Assentamentos Precários e entre as ações de Elaboração de Planos Habitacionais de Interesse Social e Desenvolvimento e Qualificação da Política Habitacional e Prestação de Serviços de Assistência Técnica para Habitação de Interesse Social, objetivando ajustar a distribuição original de recursos ao conjunto das propostas efetivamente apresentadas e que indiquem viabilidade de contratação."

Por meio das resoluções do conselho, é possível também ao governo federal impor suas prioridades em detrimento das necessidades locais: na resolução nº 27/2009, 40\% dos recursos da Ação Orçamentária de Melhoria das Condições de Habitabilidade de Assentamentos Precários foram direcionados a propostas complementares a projetos inseridos no PAC e apenas $7 \%$ poderiam ser distribuídos a propostas priorizadas e aprovadas por Conselhos Locais de Habitação de Interesse Social. Nessa mesma resolução e ação o conselho decidiu que ser uma obra complementar ao PAC seria um dos critérios para a seleção de propostas dos entes.

\subsection{Modalidades financiáveis}

Os Estados e Municípios não escolhem quais tipos de programa querem executar. Se os recursos vêm do fundo nacional, eles vêm com destinações limitadas como: provisão de moradias ou urbanização de assentamentos precários. As decisões de alocação são concentradas no âmbito do CGFNHIS: em diversas resoluções, como na de nº 4/2006, são estabelecidas quais ações poderão ser desenvolvidas com recursos do fundo. 
Dessa maneira, os entes, para obterem recursos federais, não podem inovar no desenho da política (PIERSON, 1995, p. 456):

Inovação bem sucedida pode facilitar um processo de difusão em todo o sistema, ou prover as autoridades centrais de uma justificativa para universalizar a mudança da política pública. A perspectiva de variação da política pública e experimentação é frequentemente vista como a maior vantagem de sistemas federais. ${ }^{72}$

A limitação das modalidades financiáveis oferece um custo maior aos entes que queiram inovar na política habitacional, já que restringe o acesso aos recursos federais. É claro que apenas a descentralização das decisões não garantiria inovação, criatividade ou adequação da política às especificidades de cada ente, mas o modelo escolhido não incentiva o desenvolvimento de alternativas locais.

Nesse sentido, a observação de Almeida (2008, pp. 218-219) acerca da subordinação voluntária dos entes federados:

Arrisco ainda dizer sem maior rigor de análise histórica e política que, diversamente do que se passa nos Estados Unidos da América, o presidencialismo forte em um país de abissais desigualdades regionais, como o Brasil, ressalta ainda mais a preponderância da União. Isso porque não apenas a população, mas os próprios entes federados - autônomos de Direito, porém desprovidos, em sua maioria de qualquer condição real de auto-sustentação passam a esperar que a União tudo proveja e, assim legitimada, tudo decida.

Conforme aborda Dalmo Dallari (1990, pp.62-63) sobre a autonomia dos Municípios: “[...] na atribuição das competências e na distribuição das rendas públicas, os Municípios sempre recebem muito pouco e, por isso, vivem em situação de constante dependência, ficando assim anulada a autonomia política formal."

Essas condições não promovem o desenvolvimento dos entes, prorrogando relações de subordinação (ALMEIDA, 2008, p. 233): "Essa grande preponderância jurídica e política da União ao mesmo tempo freia a possibilidade de desenvolvimento das unidades que reúnem reais condições de exercício da autonomia e perpetua a situação de dependência das demais."

A lei que criou o sistema e o fundo previu diversas ações no campo habitacional: aquisição, construção, conclusão, melhoria, reforma, locação social e arrendamento de

\footnotetext{
${ }^{72}$ Tradução livre de: "Successful innovation can facilitate a process of diffusion throughout the system, or provide a rationale for central authorities to universalize the policy change. The prospect of policy variation and experimentation is often viewed as a major advantage of federal systems."
} 
unidades habitacionais em áreas urbanas e rurais; produção de lotes urbanizados para fins habitacionais; urbanização, produção de equipamentos comunitários, regularização fundiária e urbanística de áreas de interesse social; implantação de saneamento básico, infraestrutura e equipamentos urbanos complementares aos programas habitacionais de interesse social; aquisição de materiais para construção, ampliação e reforma de moradias; recuperação ou produção de imóveis em áreas encortiçadas ou deterioradas, centrais ou periféricas, para fins habitacionais de interesse social; outros programas e intervenções na forma aprovada pelo Conselho Gestor do FNHIS.

A utilização das ações ficou limitada no fundo, durante o PPA 2008-2011 a três programas: Programa de Urbanização, Regularização Fundiária e Integração de Assentamentos Precários, com a ação Apoio à Melhoria das Condições de Habitabilidade de Assentamentos Precários; Programa de Desenvolvimento do Sistema Nacional de Habitação de Interesse Social, com as ações: Apoio à Elaboração de Planos Habitacionais de Interesse Social, Apoio ao Desenvolvimento e à Qualificação da Política Habitacional e Prestação de Serviços de Assistência Técnica para Habitação de Interesse Social; e Programa de Habitação de Interesse Social, com as ações Apoio à Provisão Habitacional de Interesse Social e a Ação de Apoio à Produção Social da Moradia. Para o PPA 20122015, foram alteradas e acrescentadas as ações de Apoio ao Fortalecimento da Política Nacional de Habitação, Apoio ao Desenvolvimento Institucional dos Agentes Integrantes do Sistema Nacional de Habitação de Interesse Social e Apoio à Sustentabilidade dos Empreendimentos de Habitação de Interesse Social.

É possível constatar algumas inovações em relação à lei, como as ações referentes aos planos e à assistência técnica, ainda que o rol original não tenha sido amplamente explorado como em relação à política de locação social.

\subsection{Dificuldades no acesso}

O SNHIS foi organizado para exigir contrapartidas dos entes federados, estruturando um sistema coordenado de ação e desenvolvendo os órgãos voltados à questão habitacional.

No entanto, considerando a realidade de diversos entes, essas exigências se mostraram obstáculos intransponíveis, levando à baixa regularidade deles no sistema. Segundo informações do Ministério das Cidades (2013), dos 26 Estados e do Distrito Federal apenas nove estavam regulares, ou seja, 18 Estados estavam impedidos de receber 
desembolsos de contratos já firmados e pleitear novos recursos. De um total de 5.564 Municípios no rol apenas 883 estavam regulares e 4.681 pendentes, ou seja, $15,87 \%$ de conformidade. Estados como Sergipe, Alagoas e Amapá não contavam com nenhum Município regular em julho de 2013.

Além da dificuldade de adequação aos parâmetros do sistema, o baixo volume de recursos e a priorização de outros programas fizeram com que não haja incentivos na busca pelo fundo, já que existem outras fontes com acesso mais facilitado e com recursos mais abundantes.

\section{Limites para o sistema}

Além dos problemas encontrados no desenho do sistema, limitações fáticas da federação brasileira, da organização dos entes federados e da integração entre eles se colocam como limites ao desenvolvimento de um sistema coordenado de políticas públicas.

\subsection{Capacidade administrativa dos Municípios}

A baixa capacidade administrativa dos Municípios se coloca como um limite à política habitacional e, especialmente, a um sistema que busca a coordenação e a autonomia dos entes federados.

A deficiência na capacidade administrativa ajuda a explicar parte dos atrasos dos entes federados na adesão ao sistema: a primeira resolução do CGFNHIS a tratar dos prazos para cumprimento dos compromissos constantes do Termo de Adesão - $\mathrm{n}^{\mathbf{o}} 2 \mathrm{de}$ 2006 - estabelecia como prazos: até 31.12.2007 para Estados, Distrito Federal e Municípios com mais de 20.000 habitantes e para a constituição dos conselhos e fundos para Municípios menores que 20.000 habitantes e não integrantes de regiões metropolitanas e 31.12.2009 para os planos dos Municípios menores. Esses prazos foram alterados pelas resoluções do CGFNHIS: $n^{\circ} 7 / 2007, n^{\circ} 12 / 2007, n^{\circ} 15 / 2008, n^{\circ} 24 / 2009, n^{\circ}$ $30 / 2009, n^{\circ} 36 / 2010, n^{\circ} 40 / 2011, n^{\circ} 44 / 2011, n^{\circ} 48 / 2011$ e $n^{\circ} 51 / 2012$ e instruções normativas: $n^{\circ}$ 4/2010 e no 85/2010. A lei do SNHIS e a instrução normativa $n^{\circ} 15 / 2011$ do CGFNHIS permitiram que Municípios menores - com menos de 20.000 habitantes e não integrantes de regiões metropolitanas - elaborem planos simplificados. 
No entanto, não são apenas o tamanho ou os recursos do Município que explicam os atrasos: uma pesquisa sobre os Planos Locais de Habitação de Interesse Social (PLHIS) na Região Metropolitana de São Paulo indicou que, em novembro de 2012, 10 Municípios não haviam iniciado seus planos: Municípios com população variando de $16 \mathrm{mil}$ a $240 \mathrm{mil}$ habitantes, e com o melhor e o segundo pior índice de desenvolvimento humano da região (Denaldi et all, 2013). Alguns dos fatores dos atrasos indicados pelos entrevistados na pesquisa foram: falta de pessoal qualificado, falta de articulação entre os órgãos municipais, pouca valorização do plano, possibilidade de acesso aos recursos independentemente da confecção dos planos.

Por outro lado, a adesão ao SNHIS é a causa provável do aumento na instalação de fundos, conselhos e planos (ARRETCHE et al., 2012, p. 40): "A incidência de conselhos nos municípios passa de 14,0\% em 2004 para 42,6\% em 2009. A presença de fundos municipais de habitação passa de 15,3\% em 2005 para 42,8\% em 2009.”

O Ministério das Cidades condicionou a autonomia dos entes federados que acessaram o fundo para obtenção de recursos para seus planos. Os Municípios que não tiveram aporte financeiro do ministério para elaboração dos planos só devem cumprir o art. $2, \S 2^{\circ}$ da resolução $n^{\circ} 2$ do CGFNHIS, ou seja, fazer planos que sejam um "conjunto articulado de diretrizes, objetivos, metas, ações e indicadores, que caracterizem, em determinado prazo, os instrumentos de planejamento e gestão dos estados, Distrito Federal e municípios para a área de habitação de interesse social”. Já Municípios que tiveram aporte de recursos do FNHIS para essa finalidade, devem ter planos que cumpram todas as resoluções do CGFNHIS e a regulamentação do ministério, ou seja, já que os entes são autônomos, a maneira encontrada para haver obediência às normas do ministério foi o condicionamento dos recursos ao cumprimento de padrões estabelecidos pelo governo central.

A adesão se deu de maneira parcial pelos Municípios (ARRETCHE et al., 2007, p. 117):

23,8\% (1.326 municípios) apenas formalizaram a adesão ao SNHIS, sem avançar nas demais etapas de inserção no sistema; 56,9\% (3.166 municípios) formalizaram a adesão ao SNHIS e constituíram o Fundo Local e o Conselho Municipal de Habitação de Interesse Social; 10,3\% (apenas 571 municípios) formalizaram a adesão ao SNHIS, constituíram o Fundo Local e o Conselho Municipal de Habitação de Interesse Social e também elaboraram o Plano Local de Habitação de Interesse Social (PLHIS). 
Essa diferença pode ser relacionada à complexidade de cada requisito, conforme pesquisa de Arretche et al. (2012, p. 113):

[...] o ano de 2007 representa o pico de publicação do Termo de Adesão no Diário Oficial da União (DOU), procedimento efetivado por mais de 4.500 municípios naquele ano. Em outras palavras, esta resposta foi bastante rápida, dado que essa declaração de intenções apresenta muito baixo custo para os municípios, fato este já evidenciado pelo fato de que 97,9\% deles publicaram Termo de Adesão no DOU.

Os Estados tiveram comportamento bastante variável nessa composição: Municípios de Estados como o Amapá, Maranhão e Sergipe não apresentaram nenhum plano, enquanto Estados como o Acre tiveram mais de 70\% dos Municípios apresentando planos e Santa Catarina mais de 30\% (ARRETCHE et al., 2007). A região Sudeste apresentou menos de $20 \%$ em todos os Estados. Estados como Ceará, Mato Grosso do Sul e Santa Catarina contaram com mais de $90 \%$ dos seus Municípios com conselhos e fundos.

Em estudo patrocinado pelo Ministério das Cidades (2007, p. 158), concluiu-se que quanto mais capacidades administrativas os Municípios apresentaram, maiores foram as possibilidades de desenvolver variados programas habitacionais, ainda que possa haver outros fatores com influência nesse resultado:

[...] quanto mais instrumentos de política habitacional, maior a possibilidade de que o governo local ofereça serviços habitacionais. Por outro lado, há possibilidade de que uma administração municipal não disponibilize nenhum programa se reduz à medida que se ampliam e diversificam os recursos administrativos de um governo municipal. Finalmente, quanto mais complexa a capacidade administrativa de um município - que conte com um órgão específico, instrumentos de aferição de demanda, conselho e fundo de habitação -, mais complexa e diversificada tende a ser sua atuação na oferta de unidades e na intervenção urbana.

Segundo outro estudo do Ministério das Cidades (2012), os Municípios que possuem algum setor responsável por habitação tiveram melhor desempenho na aprovação de propostas no Programa de Aceleração do Crescimento (PAC). Os Municípios com órgão exclusivo para habitação foram os que tiveram maior percentual de "municípios com pelo menos uma proposta selecionada" no PAC-Habitação: 68,5\%, "municípios com pelo menos um contrato": $71,7 \%$ e "municípios com pelo menos um contrato com valor desbloqueado": 55,9\%.

O relatório para a Controladoria Geral da União (CGU. FNHIS, 2009, p. 3) destaca a dificuldade das prefeituras em desenvolver os projetos: 
[...] tanto as ações de "Provimento Habitacional de Interesse Social" quanto as de "Melhoria das Condições de Habitabilidade de Assentamento Precários" estabelecem, como critério de seleção das propostas, a existência de projeto básico e projeto executivo no momento da apresentação da proposta. Por si só, tal critério é fundamental para o correto dimensionamento e previsibilidade dos recursos que deverão ser aplicados, mas por outro, municípios menores, que não possuem quadros técnicos adequados e que normalmente se enquadram em uma situação de precariedade maior, ficam prejudicados ao não serem contemplados com a alocação de recursos do FNHIS.

No relatório da CGU (CGU. SNH. 2010, p. 19) constataram-se problemas na execução dos contratos, causados pelas limitações dos entes federados:

As principais causas estruturantes que mais têm impactado no alcance dos objetivos dos Programas da SNH são as dificuldades em atuar na solução dos problemas que ocorrem na execução dos objetos pactuados, problemas esses causados em maioria pela falta de estrutura adequada da grande parte dos municípios brasileiros, o que reflete na falta de capacidade de elaborar e apresentar bons projetos, pela inexistência de cronogramas mais rígidos para cumprimento por parte dos proponentes das etapas estipuladas para contratação e execução dos contratos de repasse.

A posição da Secretaria Nacional de Habitação (CGU. SNH. 2009, p. 13) é no sentido da limitação da sua atuação tendo em vista a autonomia dos entes:

São alocados recursos financeiros, esclarecidas todas as questões referentes a projetos, regularização fundiária e licenciamento ambiental disponibilizando técnicos aptos a prestar assessoria a todas as regiões do País. Não pode, no entanto, efetuar licitações e executar obras em nome do ente federado, quer pela impossibilidade física, quer pela independência e autonomia entre as esferas de poder, sendo ainda injusta a imposição de restrições às populações carentes em decorrência das limitações operacionais de suas administrações.

\subsection{Regiões metropolitanas}

Conforme já mencionado, boa parte do déficit habitacional se encontra em áreas metropolitanas. A contiguidade dos Municípios torna o déficit e as soluções de política habitacional muito relacionadas, conforme analisa Luciana Royer (2013, p. 13):

A política habitacional é responsável pela geração de externalidades que extrapolam os limites dos municípios. Da questão ambiental à mobilidade urbana, muitos são os efeitos - positivos e negativos - associados à produção de unidades habitacionais. Assim, apesar da disciplina do uso e ocupação do solo 
ser da competência dos municípios, é inegável que a gestão da política habitacional exige um outro olhar sobre a gestão do espaço, que não coincide com os limites políticos das fronteiras federativas. A questão fundiária, por exemplo, não pode ser regulada nos estritos limites dos territórios municipais. Do mesmo modo que o mercado imobiliário não respeita os limites entre os municípios na formação do preço das unidades habitacionais, a gestão política do espaço demanda uma intervenção a partir de outras estruturas de governança.

Nessa mesma perspectiva, Nabil Bonduki (2013, p. 40-41) trata dos impactos que as políticas públicas e o mercado geram além dos limites do território municipal:

Decisões tomadas por cada município, sejam de natureza econômica, como incentivos fiscais, sejam de natureza urbana, como mudanças nas normas de uso e ocupação do solo, ou de natureza habitacional, como a remoção de favelas para implantação de obras públicas, acabam por gerar impactos significativos em outros municípios, sem que eles possam, de alguma forma, interferir nessas decisões. Mecanismos do mercado imobiliário atuante em determinado municípios acabam por afetar o valor da terra, gerando exclusão da população e migrações intrametropolitanas que, por sua vez, alteram as necessidades habitacionais de outros municípios para os quais se deslocam.

A questão habitacional, assim como outras políticas sociais, não pode ser tratada apenas localmente, sob pena de gerar efeitos contraproducentes, sobreposições de ações e até competição ineficiente entre os entes, já que algumas competências não são bem delimitadas.

No entanto, o desenho do SNHIS não garantiu a coordenação das ações: foi prevista a possibilidade da constituição de fundos e conselhos de caráter regional (art. 12, $\S 5^{\circ}$ da lei 11.124/2005), mas, segundo informações da CEF de setembro de 2013, fornecidas em resposta ao pedido de informações da autora, isso ainda não havia acontecido. Diante desse cenário, os entes federados têm agido autonomamente sem considerar os impactos das ações em outros entes.

No sistema não há incentivo para a coordenação de políticas habitacionais, o papel dos Estados é limitado e não há articulação regional das intervenções, cenário que faz parte de um problema mais amplo de governança metropolitana que se apresenta em diversas outras políticas públicas. Apesar da autonomia de cada Município que compõe a região metropolitana, seria possível dentro do SNHIS uma indução à coordenação de ações em territórios contíguos.

\subsection{Desigualdades regionais}


As desigualdades regionais representam dificuldades no desenho de políticas para todo o território brasileiro. A resolução n ${ }^{\circ}$ 4/2006 do CGFNHIS limita a atuação em todo o território nacional a áreas com $60 \%$ de ocupantes com renda até $\mathrm{R} \$ 1.050,00 .{ }^{73}$ No entanto, esse teto uniforme pode se mostrar inadequado, tendo em vista a concentração de pobres em certas regiões e o maior custo de vida em outras, que acaba relativizando a superioridade da renda.

O Censo de 2010 (IBGE, 2010) indica que as regiões Norte e Nordeste tem proporção de pessoas com renda de zero a dois salários mínimos (equivalente a $\mathrm{R} \$ 1.020,00)$ superior à média nacional $(82,48 \%)$, representando respectivamente $89,7 \% \mathrm{e}$ 91,71\% do total da população, enquanto nas regiões Centro-Oeste, Sudeste e Sul as proporções são, respectivamente, 79,64\%, 77,99\% e 77,90\%. Ou seja, uma análise superficial dos dados relativos à renda indica que as regiões Norte e Nordeste têm uma proporção de população de baixa renda muito superior às outras regiões brasileiras, o que dificulta o estabelecimento de uma meta com valores uniformes para todo o país.

Outro fator ainda mais relevante nessas desigualdades é o custo de vida, porque em determinadas regiões é possível ganhar maiores salários e ter maiores gastos, o que tornaria uma meta nacional falaciosa: ganhar mais de $\mathrm{R} \$ 1.050,00$ em São Paulo pode garantir menos qualidade de vida que ganhar menos $\mathrm{R} \$ 1.050,00 \mathrm{em}$ Belém. Um indicador que se relaciona com o custo de vida é o custo do aluguel; pesquisa realizada com dados referentes aos anos de 2002-2003 demonstra que DF e São Paulo são os Estados mais caros para a população de baixa renda (Tatiane MENEZES; Carlos R. AZZONI; Guilherme R.C. MOREIRA, 2007, p. 341): "No grupo das famílias pobres, o Estado de São Paulo é o segundo mais caro (24\% mais barato do que o aluguel do pobre em Brasília). Para essa faixa de renda os aluguéis mais baratos são de Tocantins e Ceará, ambos em torno de $47 \%$ abaixo de Brasília."

Para o ano de 2002, outra pesquisa indicou as diferenças no custo de vida nas regiões metropolitanas (Carlos R. AZZONI; Heron E. do CARMO; Tatiane MENEZES, 2003, p. 116):

Na ordem, Brasília, São Paulo e Rio de Janeiro são as mais caras, com índices de custo de vida 13,6\%,13\% e 7,4\%, respectivamente, acima da média. Em posição próxima da média encontram-se Goiânia $(+3 \%)$, Curitiba $(+2 \%)$, Porto Alegre $(+1,5 \%)$ e Belo Horizonte, esta já abaixo da média (-3,2\%). No ano em análise, a RM mais barata foi Recife, com um nível de custo de vida $-11,2 \%$ abaixo da

\footnotetext{
${ }^{73} \mathrm{Em} 2009$, esse valor foi alterado para $\mathrm{R} \$ 1.395,00$, por meio da resolução $\mathrm{n}^{\circ} 38 / 2009$.
} 
média, seguida de perto por Fortaleza, com $-11,1 \%$. Salvador e Belém vêm em seguida, com $-7,8 \%$ e $-7,2 \%$, respectivamente. Fazendo uma comparação com o nível de renda das respectivas RMs, percebe-se que as mais baratas também são as regiões mais pobres: Norte e Nordeste. Como esperado, a RM mais rica, São Paulo, é também das mais caras.

Pesquisa sobre o déficit habitacional (MCIDADES, 2009a, p. 32) verificou que mesmo com as diferenças de renda entre os Estados, a participação dos $10 \%$ mais pobres no déficit habitacional é bastante parecida, o que demonstra a dificuldade em se estabelecer um limite de renda nacionalmente uniforme e que não seja excludente:

Quanto à participação do déficit de habitações dessa fatia de população no total das carências das unidades da Federação, as diferenças não são tão acentuadas. $\mathrm{Na}$ realidade, a maioria dos percentuais fica entre $30 \%$ e $40 \%$. Ou seja, a população mais pobre, que constitui a base da estrutura social e corresponde a cerca de $10 \%$ da população total, é responsável por grande parcela do déficit independente da região considerada. As diferenças são marcantes, portanto, apenas em relação aos valores que essas populações recebem. Assim, em Santa Catarina as famílias de mais baixa renda recebem, em média, renda mensal de até 600 reais e são responsáveis por $41,9 \%$ do déficit estadual. Na Paraíba, elas recebem até 240 reais e concentram $42,4 \%$ da carência de moradias.

No PMCMV foram estabelecidos alguns limites regionais para o valor dos financiamentos, que também variam de acordo com o tamanho da população dos Municípios, considerando diferenças locais e o pertencimento a regiões metropolitanas. No entanto, outros problemas podem ser verificados como o limite das regiões metropolitanas ser igual para todos os Municípios integrantes, o que pode levar à concentração da produção habitacional em Municípios com o preço da terra mais baixo, mais periféricos.

As condicionantes nacionais impostas aos projetos podem restringir a atuação dos entes federados, inclusive limitando os efeitos benéficos da descentralização, relacionados a uma atuação mais compatível com a realidade local. Por outro lado, ampliar em demasia os tetos de financiamento acaba excluindo a população mais pobre.

\subsection{Políticas urbanas, habitacionais e outras políticas públicas}

Dentro do Sistema Nacional de Habitação de Interesse Social, uma questão de extrema relevância é a conciliação da política habitacional com as políticas urbanas, definidas por Angélica A. T. B. A. Volia, Regina C. Kato, Luiz Guilherme R. de Castro e Silvana Maria Zioni (2006, p. 7), como: 
aquelas particularmente voltadas para os processos de produção, reprodução, transformação e apropriação do ambiente construído, incluindo as infraestruturas e estruturas físicas, os serviços e equipamentos urbanos, sua localização relativa no território e as práticas sociais aos quais se articulam e dos quais não podem ser separadas.

Essa questão da importância do aspecto urbano da política habitacional esteve presente na construção do $\mathrm{BNH}$, mas sua prática ignorou a relevância do SERFHAU, subordinando-o aos dirigentes do banco. A realização de políticas habitacionais sem preocupação com a infraestrutura urbana não resolve o problema, podendo apenas, no limite, deslocá-lo do indicador de déficit habitacional para o de inadequação domiciliar por possibilitar um acesso ruim aos serviços públicos como saneamento básico, transporte público e iluminação elétrica.

A lei de criação do SNHIS indica que a aplicação dos recursos do fundo deve estar ligada ao plano diretor ${ }^{74}$ ou legislação equivalente, mas não há instrumentos ou condicionantes de financiamento que garantam essa relação. Existe uma proposta de criação de um Sistema Nacional de Desenvolvimento Urbano (SNDU), mas ainda não foi transformada em um diploma legal. A resolução do CGFNHIS $n^{\circ}$ 2/2006 indica que a aplicação deve ser compatível também com os Planos Plurianuais, instrumentos de planejamento quadrienal do Poder Público.

Outra questão relevante é a dificuldade em coordenar o planejamento entre os entes federados e no âmbito de cada um deles. Planos setoriais, planos diretores, planos plurianuais: há uma dificuldade de cooperação, como observa Leda V. Buonfiglio e Rodrigo D. Bastos (2011, p. 8):

Mas como é possível haver a consolidação de uma política urbana territorial no município quando os próprios mecanismos e ferramentas de planejamento se traduzem em planos municipais setoriais - de saneamento; de desenvolvimento; de habitação; de mobilidade; de desenvolvimento econômico - que não dialogam entre si e estão desarticulados de uma política urbana territorial? Como dar conta de um planejamento urbano integrado quando para cada política social é instituído um Conselho Municipal?

Outro tema que a descoordenação das ações afeta é a conclusão de empreendimentos habitacionais: como aborda Evaniza Rodrigues (2013), no PMCMV há desconexão entre os cronogramas dos empreendimentos e das concessionárias de serviços

\footnotetext{
${ }^{74}$ Constitucionalmente, apenas Municípios com mais de 20.000 habitantes precisam ter plano diretor, o que, em 2010, equivalia a 26,74\% do total dos Municípios brasileiros.
} 
públicos dos entes federados, que muitas vezes atrasam a entrega das unidades habitacionais. A mesma autora aponta problemas de descoordenação entre as exigências da Caixa e de órgão municipais e estaduais responsáveis pelos licenciamentos e autorizações.

O SNHIS não previu um incentivo estruturado à utilização dos instrumentos urbanísticos, especialmente aqueles previstos no Estatuto da Cidade. Dessa forma, Municípios que 'fazem sua lição de casa' não têm mais recursos direcionados aos seus territórios que outros, já que as formalidades exigidas no sistema são apenas indicadores de processo, demonstrando o cumprimento de procedimentos formais. Os Municípios que conseguem melhorar a distribuição dos vazios urbanos, fazer regularização fundiária, demarcar ZEIS etc. não têm prioridade no investimento dos recursos da habitação.

Esta foi uma das preocupações do Plano Nacional de Habitação (PlanHab), que acabou sendo preterido no desenvolvimento do PMCMV, conforme aborda Bonduki (2009, p. 13-4):

O PlanHab propôs incentivar, com prioridade no acesso aos recursos, os municípios que adotassem políticas fundiárias e urbanas corretas, como a instituição do imposto progressivo para combater os imóveis ociosos e subutilizados, lembrando que quase 2 mil municípios formularam planos diretores e, na sua grande maioria, não puseram em prática instrumentos para combater a especulação imobiliária.

Em análise sobre os Municípios beneficiados com verbas do governo federal no PMCMV e no Apoio à Provisão Habitacional de Interesse Social do SNHIS, o IPEA (2012, p. 11) observou que os Municípios que não utilizavam instrumentos urbanísticos tiveram mais acesso às verbas do primeiro programa, quando o oposto seria o desejável, tanto para incentivar os Municípios, quanto para que os recursos fossem bem mais empregados:

A análise feita acima mostra que os municípios de até 50 mil habitantes que foram selecionados para integrar o programa MCMV são aqueles com as menores presenças de instrumentos de planejamento urbano e de planejamento setorial de habitação (especialmente os previstos no SNHIS, que dispõem sobre planejamento e gestão participativos), frente aos municípios que executaram Aphis.

Analisando-se a distribuição de recursos nos programas do SNHIS e no MCMV observou-se que o segundo não prioriza Municípios que tenham melhor estrutura institucional (2012, p. 9):

Com efeito, o grupo dos municípios que executaram Aphis mostra maior presença de conselho e de fundo quando comparado ao grupo daqueles 
municípios que não executaram. Novamente, essa tendência é mais forte entre os municípios com população menor que 20 mil habitantes, uma vez que há $46 \%$ conselhos e fundos a mais. Entre os municípios de 20 mil a 50 mil habitantes que executaram Aphis, as presenças do conselho e do fundo são 39\% e 37\%, respectivamente, mais frequentes. Mesmo que os Plhis sejam sempre menos frequentes que conselhos e fundos, constata-se uma frequência maior em termos de presença do plano entre os municípios de até 20 mil habitantes que executaram Aphis - $24 \%$ mais frequente. Naquilo que se refere aos municípios selecionados para o MCMV, também entre os instrumentos da política setorial de habitação se repete a tendência contrária observada para conselhos de política urbana e planos diretores. Assim, conselhos e fundos de habitação são de $7 \%$ a $10 \%$ menos presentes nos grupos de municípios que tiveram seleções para o MCMV em 2009/2010. Em 2011/2012, os contrastes são aprofundados, havendo diferenças da ordem de $16 \%$ a $25 \%$ conselhos e fundos a menos nos grupos de municípios de ambas as faixas populacionais selecionados.

Os instrumentos disponíveis têm sido utilizados muito timidamente pelos Municípios: ainda que o Estatuto da Cidade seja de 2001, em pesquisa sobre os planos diretores do Ministério das Cidades (2006) realizada em 1.552 Municípios em 2006, apenas $14,9 \%$ deles tinham ação para vazios urbanos e 13,7\% apresentavam oferta de terras para novas moradias.

Os Municípios, com sua competência de regulação do território, deveriam garantir a localização adequada dos empreendimentos habitacionais financiados por eles ou pelos outros entes federados, mas o interesse nos recursos e nas obras acaba se sobrepondo, conforme analisa Luciana Corrêa Lago (2011, p. 8):

O poder e o dever dos municípios de controlar a localização e a qualidade dos novos empreendimentos não estão sendo exercidos. As prefeituras não têm condições técnicas e/ou vontade política para impor ações regulatórias, direcionando os empreendimentos para áreas com infra-estrutura. No entanto, muitos gestores municipais invertem o problema, argumentando a falta de recursos para garantir a infraestrutura no ritmo do Programa MCMV. A aplicação dos instrumentos de planejamento territorial, como a ZEIS em áreas vazias, previstos nos Planos Diretores e a criação de um banco de terras para habitação popular não parecem estar na ordem de prioridades das prefeituras.

Uma das consequências é que a não utilização de instrumentos que permitam melhor uso de áreas subaproveitadas acaba gerando procura por mais terra pelos empreendedores, o que, somado ao aumento do crédito habitacional e outros fatores, implica no aumento do preço da terra, como aborda Mariana Fix (2011, p. 146): 
No MCMV, subsídios públicos maiores na camada de 0 a 3 salários mínimos garantem uma parcela da produção destinada de fato à baixa renda. Os incorporadores voltados para a faixa de 3 a 10, contudo, conseguiram já elevar os limites de financiamento de modo a atingir uma população com rendimentos maiores. O preço da terra torna cada vez mais difícil a produção para renda mais baixa.

Sobre os PLHIS, estudo do IPEA (2011, p. 34) indica a desvinculação dos planos à liberação de recursos, o que desestimula a utilização desses instrumentos:

Uma fragilidade dos PLHIS, como se sabe, é a não obrigatoriedade de sua previsão legal, estando, assim, sob a discricionariedade dos governos municipais e estaduais a sua implementação, que também dependerá fundamentalmente da presença e da pressão da sociedade. Por outro lado, cabe ao governo federal efetivar o SNHIS como "centralizador de programas e projetos" e minimizar a alocação de recursos fora desse marco.

Outro aspecto importante acerca da coordenação dos entes federados é a necessidade de inclusão dos bens públicos na regulação do território (DI PIETRO, 2004, p. 808):

Assim, embora a competência para adoção das medidas de política urbana seja do Município, ela pode alcançar inclusive bens públicos estaduais e federais, desde que inseridos na área definida pelo plano diretor. [...] pelo exposto se conclui que a ideia de função social, envolvendo o dever de utilização, não é incompatível com a propriedade pública. Esta já tem uma finalidade pública que lhe é inerente e que pode e deve ser ampliada para melhor atender ao interesse público, em especial aos objetivos constitucionais voltados para o pleno desenvolvimento das funções sociais da cidade e à garantia do bem-estar de seus habitantes.

Nesse caso, a utilização dos instrumentos urbanísticos, como o parcelamento compulsório e o IPTU progressivo, pode facilitar o melhor aproveitamento de áreas com infraestrutura em que se encontrem propriedades públicas ${ }^{75}$, apesar de existirem posicionamentos discordantes. ${ }^{76}$

Outra questão relevante é a regulamentação local do Estatuto da Cidade e de outras legislações ligadas à habitação e planejamento do território. Elas podem, não apenas

\footnotetext{
${ }^{75}$ Alexandre Levin (2010) defende a aplicação da desapropriação-sanção do estatuto da cidade para imóveis de entidades autárquicas e fundacionais federais e estaduais que não estejam afetados a suas atividades essenciais. Letícia Queiroz de Andrade (2006) defende a possibilidade de desapropriação de bens públicos por outros entes da federação com respeito ao maior benefício coletivo possível.

${ }^{76}$ Fernando Dias Menezes de Almeida (2002) é contrário à aplicação em propriedades públicas, tendo em vista a imunidade tributária constituicional e a limitação do decreto-lei no 3.365/1941.
} 
neutralizar, como também subverter os efeitos buscados na legislação federal. Como observa José R. de Faria (2013, p. 18) em estudo acerca da utilização do IPTU progressivo em três Municípios:

1. A função social da propriedade urbana não está necessariamente vinculada à democratização do acesso à terra urbanizada; 2. Os instrumentos urbanísticos correlatos não são necessariamente utilizados com vistas ao combate à especulação ou à valorização imobiliária e, ao contrário, podem ser funcionais para desobstruir processos de valorização.

Especificamente, a utilização do instrumento do estatuto em Curitiba levou ao efeito contrário ao que se propunha (FARIA, 2013, p. 13):

Ao contrário de consolidar e regularizar a moradia de segmentos populares em áreas centrais e infraestruturadas, a aplicação desse instrumento urbanístico em Curitiba penaliza os proprietários que não conferem algum uso ao imóvel que impeça a sua ocupação irregular para fins de moradia.

No caso do PMCMV, os Municípios mudam sua regulação urbanística para se adaptarem ao programa: na portaria $n^{\circ} 465 / 2011$ do Ministério das Cidades cabe aos Estados, Municípios e Distrito Federal apresentarem propostas legislativas para o reconhecimento dos empreendimentos como ZEIS ${ }^{77}$. É necessário verificar até que ponto essas mudanças pontuais fortalecem ou enfraquecem os instrumentos, talvez seja importante um passo adiante na avaliação da implementação deles: além de sua existência e territorialização nos planos diretores, seria essencial verificar sua efetividade de acordo com os objetivos da reforma urbana.

A lei n ${ }^{\circ}$ 5.990/2012 do Município de Cascavel/PR definiu como ZEIS: “os imóveis de propriedade do Município ou que venham ser adquiridos pelo Poder Público Municipal e COHAVEL e que sejam destinados à construção de novos empreendimentos habitacionais de Interesse Social.” É claro que as cidades passam por processos dinâmicos e revisões do planejamento são esperadas, mas, neste caso, há um zoneamento extremamente pontual, permitindo critérios diferenciados de construção em qualquer imóvel destinado ao programa, independente do entorno, do plano diretor ou do zoneamento previamente determinado.

\footnotetext{
${ }^{77}$ Sobre as ZEIS, DI SARNO (2012, p. 153) comenta: "Visa, referido instrumento, flexibilizar os índices urbanísticos em dada área urbana, permitindo dimensões de construções, estímulos tributários, entre outros instrumentos, para realizar o direito à cidade da coletividade afetada (ordenar a ocupação), flexibilização essa não permitida para outros casos, Cria uma igualdade de oportunidades no estabelecimento de moradia com critérios mínimos de dignidade."
} 
Adauto Cardoso et al. (2011, p. 12) tratam das alterações legais trazidas pelo PMCMV no Município do Rio de Janeiro:

A flexibilização da legislação urbana foi promovida através da Lei Complementar $\mathrm{n}^{\circ} .97$ de 10 de julho de 2009, a qual permite: a construção de UHs com área reduzida em relação à legislação geral vigente; a ampliação do número de pavimentos sem elevador; uma menor taxa de impermeabilização nos lotes e a dispensa de algumas exigências nas intervenções, a exemplo do número de vagas de garagem, dimensionamento das áreas de recreação, dimensão máxima de projeção horizontal, etc. Por outro lado, exige-se que os terrenos apresentem testada para logradouros que disponham de capacidade técnica para abastecimento de água, as quais sejam capazes de atender à demanda prevista; energia elétrica e iluminação pública; condições para uma solução adequada de tratamento e esgotamento sanitário; drenagem pluvial; possibilidade de atendimento por transporte público e proximidade de equipamentos públicos de saúde e educação. Destaca-se que a legislação pede apenas que o logradouro possua "capacidade técnica" para implantação destes serviços, não necessariamente que estes já estejam disponíveis para o empreendimento no momento do recebimento das chaves pelas famílias.

Além da legislação urbanística, diversos Municípios têm doado terrenos e concedido benefícios fiscais para a realização dos empreendimentos, inclusive Municípios bastante populosos e ricos como São Paulo (lei $\mathrm{n}^{\mathrm{o}}$ 15.360/2011) e Campinas (lei $\mathrm{n}^{\mathrm{o}}$ 13.580/2009), que isentou de taxas e emolumentos sobre a expedição de diretrizes urbanísticas, de análises, aprovações e certificados de conclusão, do Imposto sobre Transmissão Inter Vivos de Bens Imóveis (ITBI) sobre a primeira transmissão do imóvel produzido e do Imposto Sobre Serviços de Qualquer Natureza (ISSQN). O Município de Ananindeua/PA por meio do decreto $\mathrm{n}^{\circ} 14.583 / 2011$ concedeu benefícios fiscais, no caso isenção do Imposto sobre Serviços de Qualquer Natureza (ISSQN), à Construtora Effece Ltda e à Enaco - Empresa Nacional de Construções, com a justificativa de criação de novos empregos e pela redução do déficit habitacional.

O que essas alterações na legislação demonstram é que se o esforço do governo federal fosse no sentido de fortalecer os instrumentos e a regulação urbanística, elevando a qualidade e a efetividade dos planos diretores e planos locais de habitação de interesse social, as obras poderiam incentivar ações dos entes federados nesse sentido, já que os recursos são indutores de políticas. No entanto, a priorização é dada aos Municípios que mais apresentam benefícios para a instalação de unidades habitacionais em seus territórios como, por exemplo, a doação de imóveis no âmbito do PMCMV. 
Apesar do preço da terra estar sendo um empecilho à construção de unidades bem localizadas para a faixa de menor renda, não se tem pensado na intensificação do combate à especulação imobiliária e ao mau uso do território urbano (Renato PEQUENO; Clarissa FREITAS, 2013, p. 135):

É sintomático perceber que no debate acerca da execução do programa em Fortaleza, todos os atores entendam que o alto preço dos terrenos corresponda a um entrave ao andamento do programa, sem que nenhum deles mencione os instrumentos de combate à especulação imobiliária como uma possível solução.

\section{Recursos na habitação}

Historicamente, o gasto orçamentário com habitação é baixo, são utilizados muitos recursos de fora do orçamento, especialmente para o financiamento habitacional. No entanto, esses valores são onerosos, ou seja, exigem seu retorno, como o FGTS e o SBPE; nesse caso, o papel do Estado é de regulação, direcionando a aplicação de recursos que não são próprios (BRASIL. Via Pública; Lab hab-Fupam; Logos Engenharia. 2008, p. 24-25):

A afirmação vale para todos os entes da federação - União, estados e municípios, que entre 1964 e 1986 sequer incluíam a rubrica habitação nos seus orçamentos, sendo que os agentes promotores do SFH no âmbito dos estados e municípios, as Cohab's, embora fossem empresas estatais, atuavam de maneira quase autônoma, respondendo mais ao $\mathrm{BNH}$ do que aos governos estaduais e municipais.

As despesas na função habitação apresentam baixos valores pagos em relação aos valores empenhados e liquidados. Em 2007, por exemplo, de uma dotação inicial de $\mathrm{R} \$ 494.453 .857,00$, empenho de $\mathrm{R} \$ 303.532 .041,00$, foram pagos $\mathrm{R} \$ 252.849,00^{78}$, ou seja, $0,083 \%$ do liquidado.

Em relação ao FNHIS, desde o início de seu funcionamento em 2006, todos os recursos da função habitação corresponderam aos valores do fundo ${ }^{79}$. Grande parte dos recursos orçamentários tornaram-se restos a pagar, em 2008, por exemplo (TCU, 2008, p. 303): "De R\$ 4,5 bilhões empenhados em 2007 pelo FNHIS, 97\% foram inscritos em restos a pagar não-processados."

\footnotetext{
${ }^{78}$ Dados retirados do SIGABRASIL.

${ }^{79}$ Com exceção do ano 2008, em que $\mathrm{R} \$ 48.067 .902,00$ da função habitação não corresponderam a valores do fundo.
} 


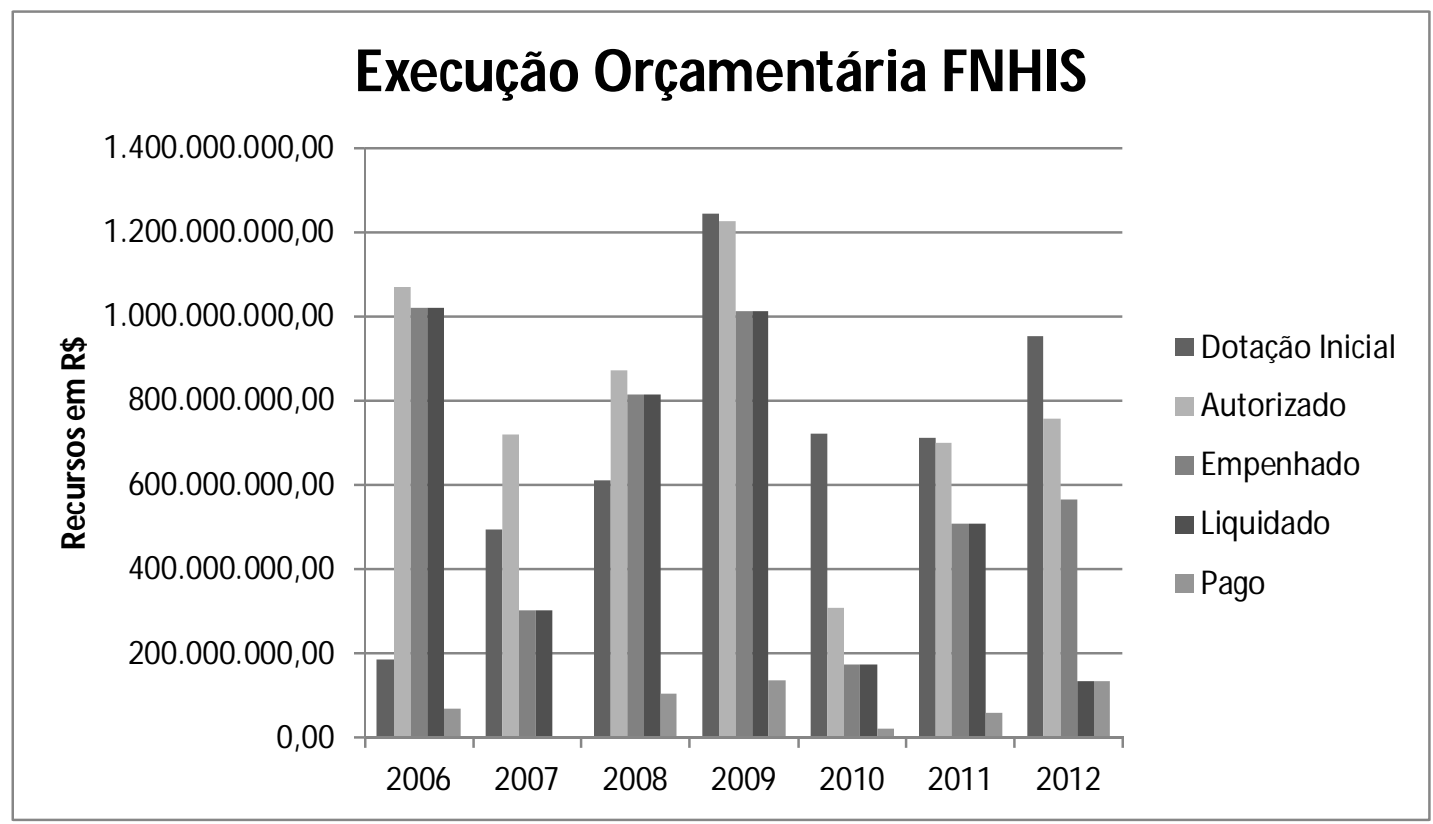

Fonte: SIGABRASIL.

Mesmo no PMCMV, mais prioritário que o sistema, em 2010, a dotação foi de $7.307 \mathrm{mi}$, o empenho de $6.855 \mathrm{mi}$, a liquidação de $164 \mathrm{mi}$ e o pagamento de $164 \mathrm{mi}$, ou $2 \%$ da dotação atualizada. O que resultou em $88 \%$ dos recursos inscritos ao fim do ano como restos a pagar não processados (TCU, 2010, p. 286). Mesma observação da CGU (CGU. SNH, 2010, p. 6) em seu relatório de 2010:

O quadro acima mostra que a SNH continua com elevado percentual de obras paralisadas e não-iniciadas. No caso das obras não-iniciadas, observa-se que 3/4 das mesmas foram contratadas até 2009, sendo que mais da metade foram contratadas até 2008. Este fato implica na inexecução das ações de governo e nas sucessivas prorrogações de Restos a Pagar.

No relatório do TCU de 2011 (TCU, 2011), é possível observar a prioridade da Habitação de Mercado $^{80}$ dentro do Programa de Aceleração do Crescimento: a execução acumulada até 2010 foi de 216,9bi (ou 242,6\% da previsão de 2007) e para a Habitação de Interesse Social foram 0,4bi (ou 2,3\% da previsão de 2007). Ou seja, o financiamento para a camada mais pobre da população teve execução bastante inferior ao financiamento para a camada superior de renda. A prioridade à Habitação de Mercado fez com que ela significasse $49 \%$ da execução total do PAC.

No orçamento do governo federal, a despesa empenhada na função habitação atingiu em 2011 o valor de $\mathrm{R} \$ 508.059 .854,00$, sendo o total das despesas empenhadas:

\footnotetext{
${ }^{80} \mathrm{~A}$ maior parte corresponde a financiamento SBPE.
} 
$\mathrm{R} \$ 1.676 .831 .326 .896,00$, ou seja, a função habitação representa apenas $0,03 \%$ do total. Desses recursos, $\mathrm{R} \$ 393.365 .732,93$ foram transferidos a Municípios e $\mathrm{R} \$ 65.334 .266,59$ para Estados ou Distrito Federal.

A soma das despesas empenhadas na função habitação no ano de 2011 nos Estados da federação foi de $\mathrm{R} \$ 3.113 .258 .534,02$. Rondônia não declarou despesa empenhada na função habitação nesse ano. Em relação aos Estados, a média dos gastos na função habitação é de $0,57 \%$ do total empenhado. É possível observar, por exemplo, que apesar do gasto do Estado de São Paulo ser o maior, proporcionalmente ao total de despesas empenhadas é inferior ao de Estados como Acre, Alagoas ou Amazonas.

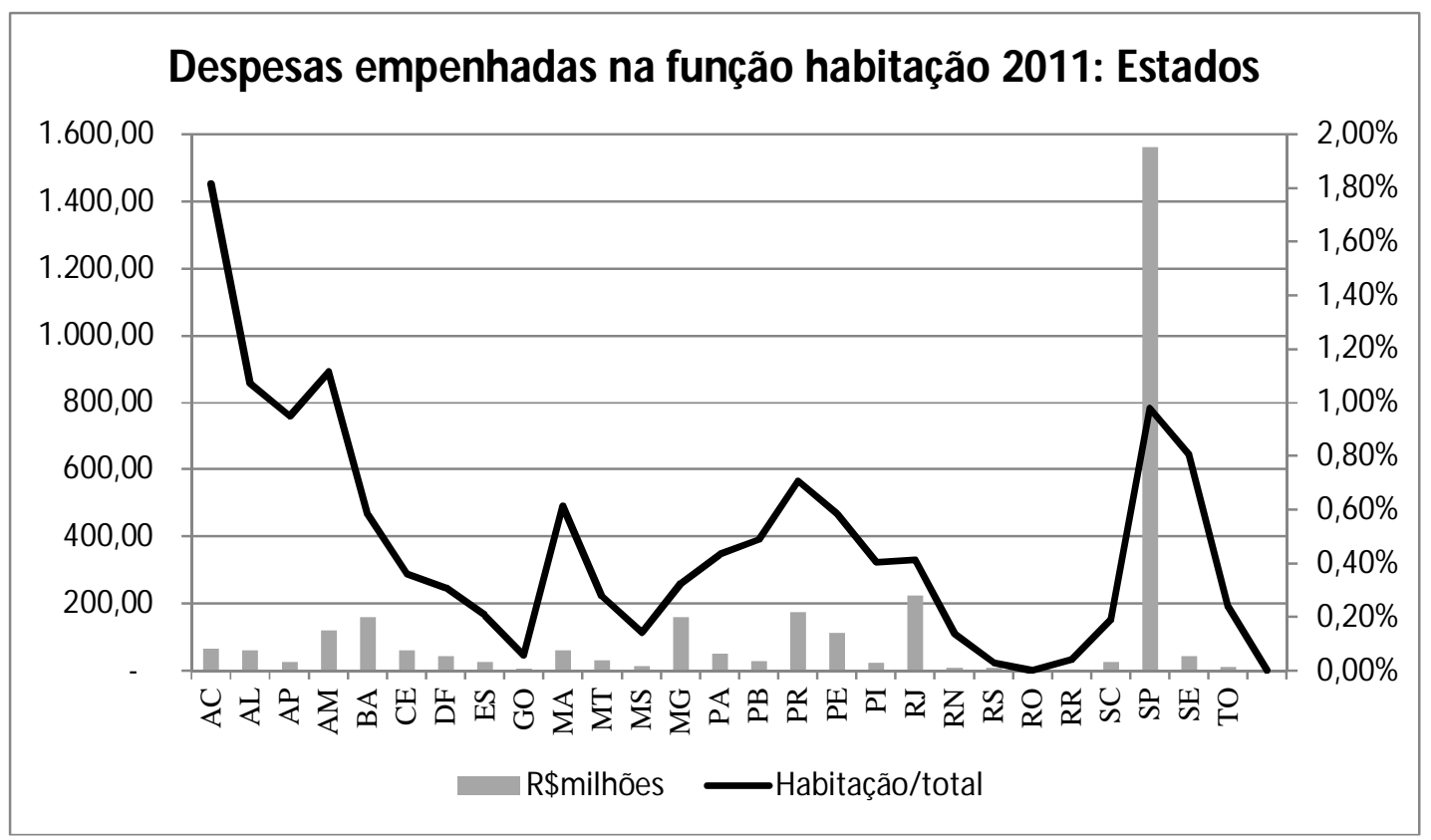

Fonte: STN.

O total de despesas empenhadas na função habitação nos Municípios em 2011 foi de R \$ 3.798.058.467,76. Os dados são fornecidos pelos entes federados, estando sujeitos a incorreções. Nem todos os Municípios apresentaram suas informações: em 2011, foram 5.194 . 


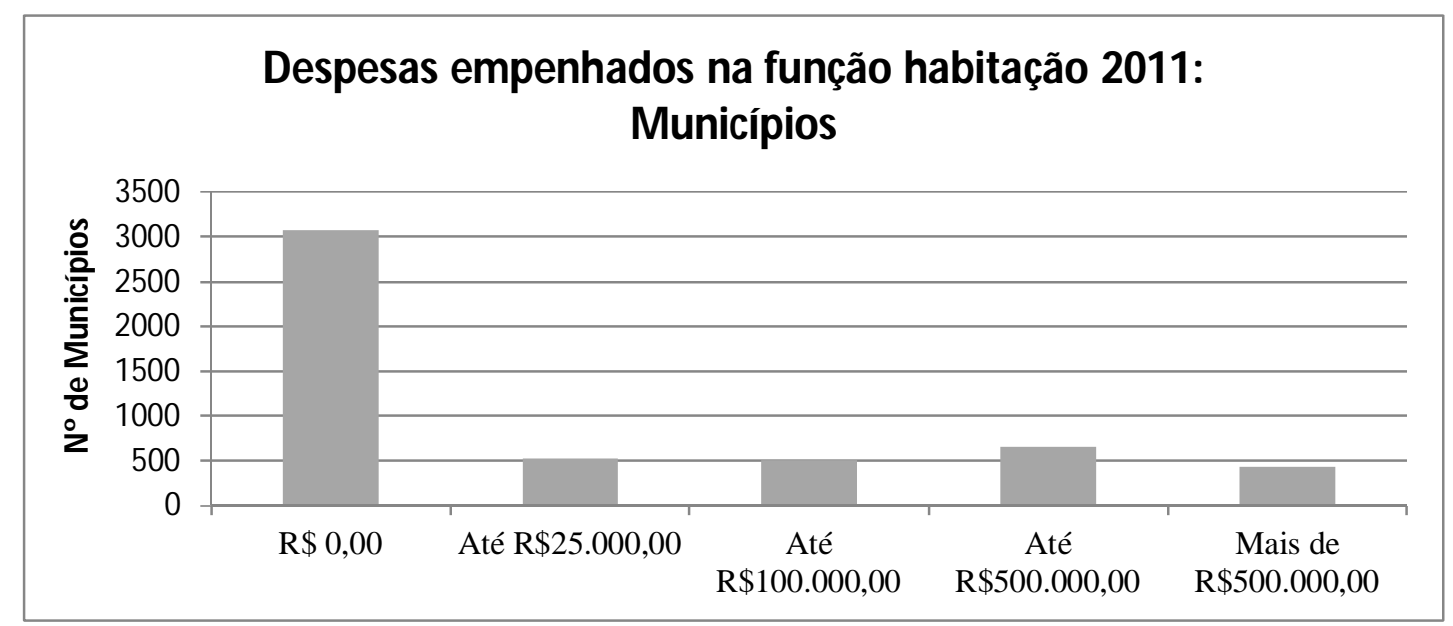

Fonte: STN.

A relação entre a média das despesas empenhadas na função habitação e a média do total das despesas empenhadas nos Municípios é de 1,07\%.

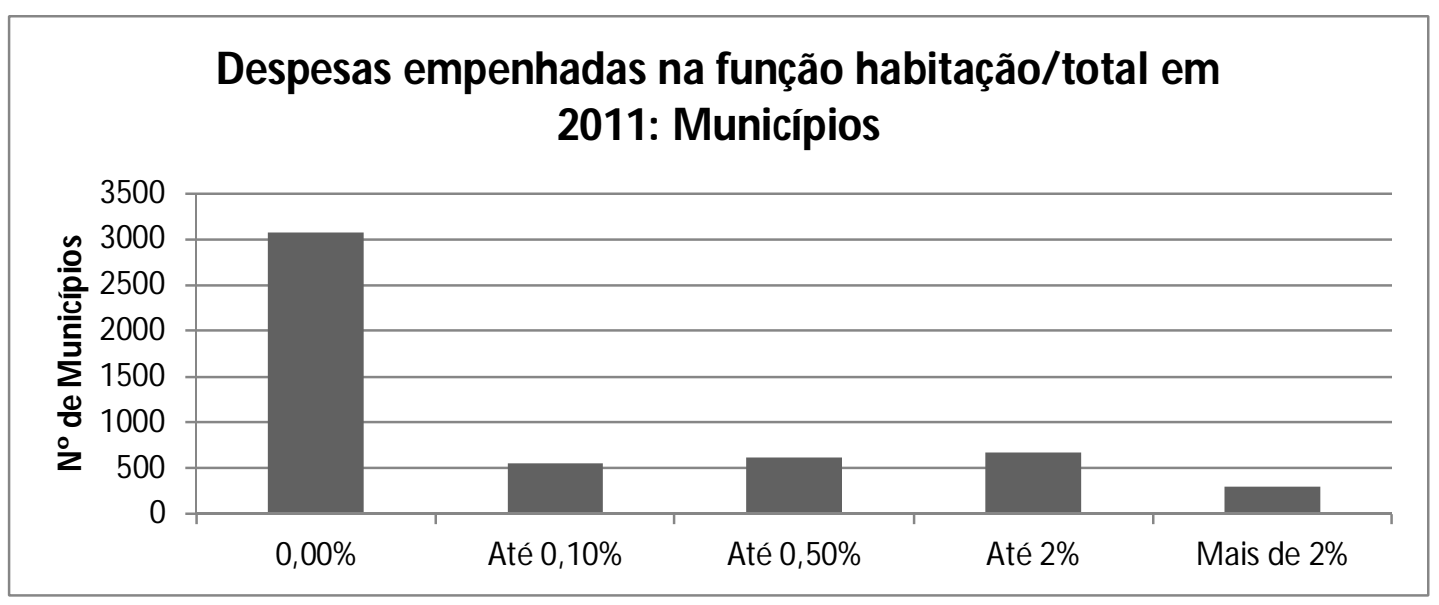

Fonte: STN.

Os valores dos recursos onerosos, no entanto, são muito superiores ao total das despesas orçamentárias em habitação em todos os níveis de governo, o que indica que a priorização é para o financiamento que precisa ser devolvido/pago, dificultando o acesso para a maior parte da população que faz parte do déficit com renda familiar de até três salários mínimos.

\subsection{Destaque ao financiamento habitacional}

O modelo de política pública habitacional predominante tem sido o financiamento à propriedade privada individual: a utilização de recursos do SBPE é direcionada ao 
financiamento da aquisição de imóveis novos, usados e da construção e a utilização dos recursos do FGTS tem sido feita privilegiando o financiamento individual e o apoio à produção. Os recursos do FNHIS têm sido bastante inferiores a essas duas outras fontes, conforme aponta estudo sobre a Política Nacional de Habitação de 2005 a 2011 realizado por Glória C. Figueiredo, Nelson Baltrusis e Elizabeth Oliveira (2013):

Considerando os recursos aportados pelas três fontes indicadas, tem-se que os recursos destinados no âmbito da PNH totalizaram R\$ 342.182.638.954,00, sendo R \$ 232.524.813.910,00 de contratos realizados com recursos do SBPE, R\$ 99.675.710.000,00 relativos a contratos de habitação popular com recursos do FGTS e R\$ 9.982.115.044,00 de valores realizados do OGU, relativos a Programas executados pelo MCidades, incluindo as subvenções do PMCMV. Pode-se constatar o domínio dos recursos do SBPE, com a produção habitacional de mercado se constituindo na ação dominante da atual Política Nacional de Habitação.

No FGTS, o programa Carta de Crédito Individual destina recursos para financiamentos a pessoas físicas individualmente para aquisição de imóveis novos ou usados, construção de unidades habitacionais, aquisição ou execução de lotes urbanizados ou conclusão, reforma, ampliação ou melhoria de unidade habitacional, beneficiando pessoas com renda familiar mensal de até $\mathrm{R} \$ 4.300,00$, admitindo-se a elevação da renda familiar mensal bruta, até $\mathrm{R} \$ 5.400,00$, nos casos de financiamentos vinculados a imóveis situados em Municípios maiores, capitais ou integrantes de regiões metropolitanas.

O programa Carta de Crédito Associativo financia imóveis na planta (FGTS, 2010, p. 67):

[...] que requerem maior tempo de maturação, análise e execução em relação aos projetos apresentados. No ano de 2010, os recursos do Programa Carta de Crédito Associativo foram reduzidos em, aproximadamente, $85 \%$, em relação ao orçamento inicial (de $\mathrm{R} \$ 3,50$ bilhões para $\mathrm{R} \$ 276,00$ milhões), sendo remanejados para o programa de Apoio à Produção de Habitações, favorecido pelo forte incentivo decorrente da continuidade do PMCMV.

A não ser no ano de $2012^{81}$, em todos os anos estudados, os recursos para as entidades foi superior aos recursos destinados a COHABs no Programa Carta de Crédito Associativo.

O Programa Pró-moradia é voltado a órgãos públicos para a produção de soluções habitacionais, incluindo urbanização de favelas e desenvolvimento institucional, voltado à

\footnotetext{
${ }^{81}$ Para o ano de 2008 não há essa informação no relatório.
} 
população com rendimentos de até três salários mínimos ou Municípios que sofreram desastres naturais, tendo participação bastante reduzida no total de recursos do FGTS. Cabe ressaltar que, a partir do lançamento do Programa Minha Casa, Minha Vida, em março de 2009, o Pró-Moradia focou seus processos seletivos na modalidade destinada à urbanização e regularização de assentamentos precários (FGTS, 2011).

O Programa Apoio à Produção de Habitações previsto na resolução do CCFGTS n ${ }^{\circ}$ 485/2005 tem como objetivo: "destinar recursos financeiros para empreendimentos de produção habitacional ou reabilitação urbana, voltados à população-alvo do FGTS, por intermédio de financiamentos concedidos a pessoas jurídicas do ramo da construção civil."

Com o surgimento do PMCMV, a utilização do financiamento para imóveis novos se destacou ainda mais (FGTS, 2010, p. 66):

Em 2010, foram realizadas 90.834 operações destinadas à aquisição de imóveis novos e 62.650 operações destinadas à construção, representando um aumento de $112 \%$ e $67 \%$, respectivamente, em relação ao ano de 2009 , o que somadas, equivalem a mais de $57 \%$ do total de financiamentos no período. Esse aumento se deu em grande parte pelo desempenho do PMCMV.

Houve um aumento significativo no volume de recursos destinados ao Programa Carta de Crédito Individual e ao Programa de Apoio à Produção:

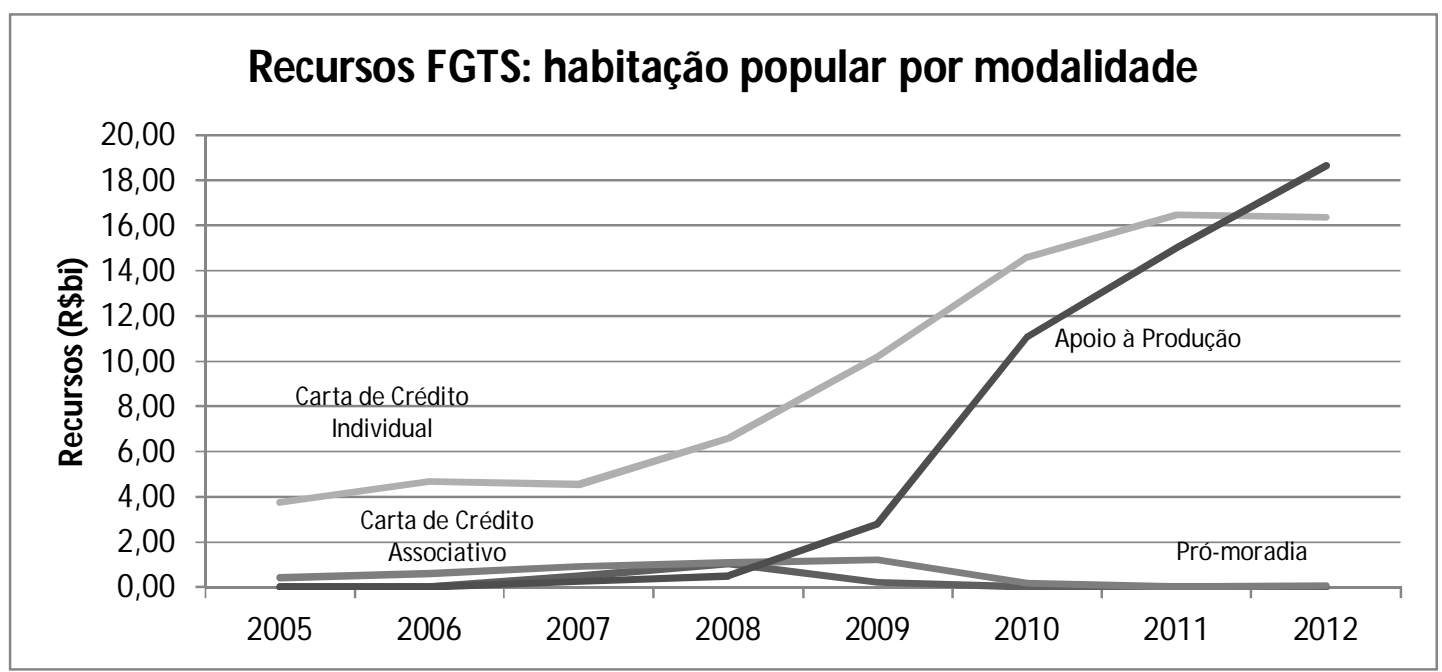

Fonte: Relatórios Financeiros do FGTS.

O percentual da Carta de Crédito Individual diminuiu bastante devido ao crescimento do Apoio à Produção, mas o volume de recursos dessa modalidade e do total cresceu muito no período. A partir de 2012, o Programa Apoio à Produção torna-se o mais importante percentualmente no fundo: 


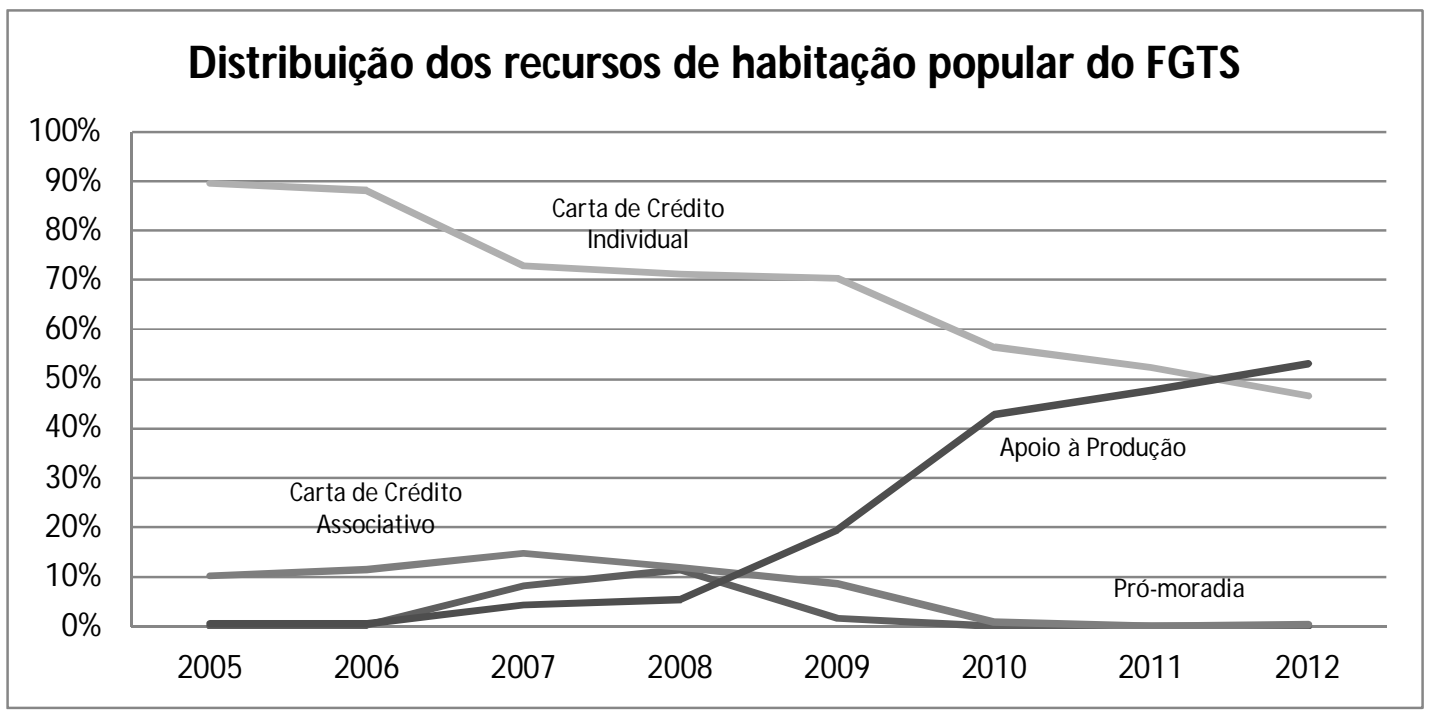

Fonte: Relatórios Financeiros do FGTS.

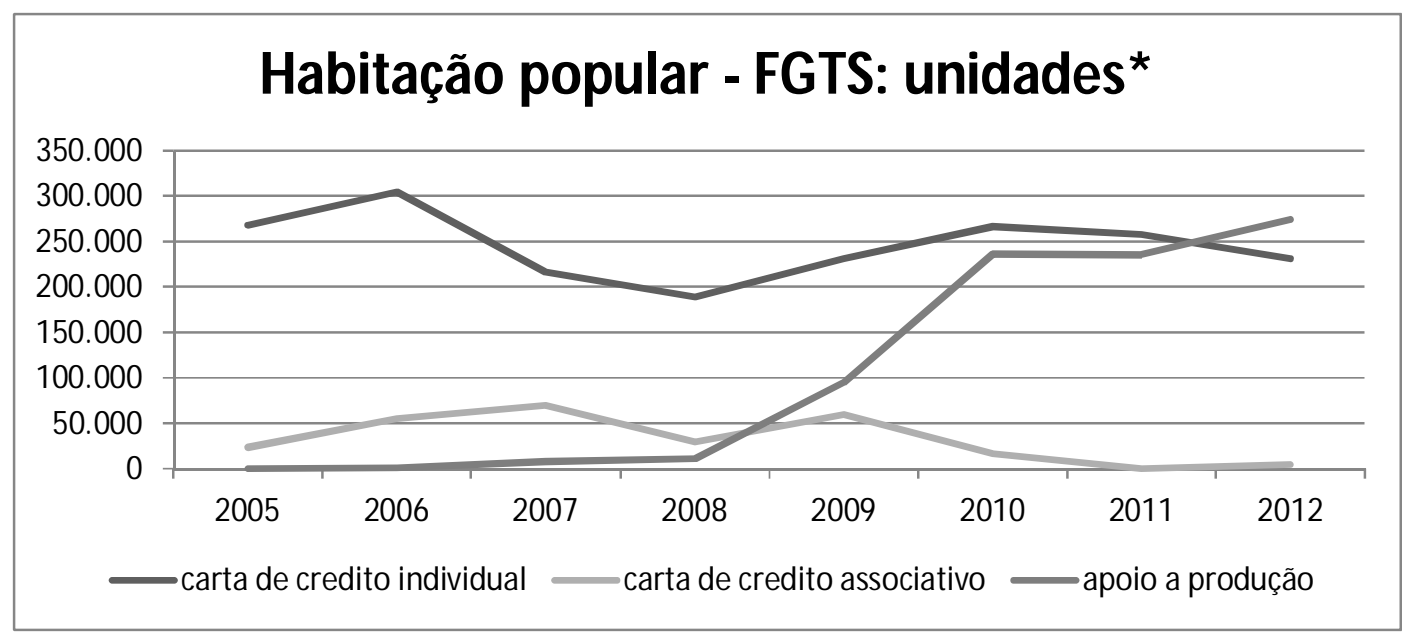

Fonte: Relatórios de Gestão do FGTS.

* Não há dados sobre unidades produzidas em 2011 no Programa Pró-moradia.

Percebe-se que a política habitacional é fundada principalmente no crédito, mesmo quando o público-alvo da política pública é a população de menor renda, conforme considera Royer (2009, p. 21): "De fato, é curioso observar que os instrumentos de crédito se transformaram no objetivo principal da política habitacional, independentemente de sua adequação para atacar o problema."

Esse deslocamento da questão social para o financiamento do indivíduo desloca o entendimento da habitação como um direito social, ficando ela reduzida ao acesso a crédito, segundo Royer (2009, p. 164):

[...] o cidadão beneficiário de direito passa a ser encarado como um consumidor e a questão habitacional, como uma questão individual de quem pode ou não 
pode tomar crédito, de quem pode ou não oferecer garantia contra os riscos temidos pelos agentes financeiros. O Estado, a quem deveria competir organizar o desenvolvimento social, garantindo o acesso universal à moradia, limita-se a corrigir as decantadas falhas de mercado, sustentando a suposta excelência da racionalidade econômica. Uma consequência grave da recepção hegemônica do pensamento neoclássico é a simplificação do problema habitacional à questão individual, ignorando a perspectiva do conflito e o fato da apropriação do excedente refletir um sistema social estratificado e hierarquizado.

\subsection{Destaque à construção habitacional}

Sob uma perspectiva mais geral, a construção de unidades habitacionais foi observada como a política mais utilizada pelos Municípios, dentro da relação de opções oferecidas na Munic ${ }^{82}$, conforme Arretche (2012, p. 125): “A construção de unidades habitacionais é o tipo de programa mais frequente, ou seja, ocorreu em 66,5\% dos municípios em 2001-2004 (3.696 menções); em 48,5\% dos municípios em 2005 (2.697 menções); e em 60,7\% em 2007-2008 (3.377 menções)."

O direcionamento dos recursos dentro do FGTS após o PMCMV ampliou os valores para a construção em diversos programas. O programa Carta de Crédito Individual do FGTS se alterou no período estudado: a modalidade que representava mais da metade do destino dos recursos - Material de Construção - perdeu importância para a aquisição de imóveis:

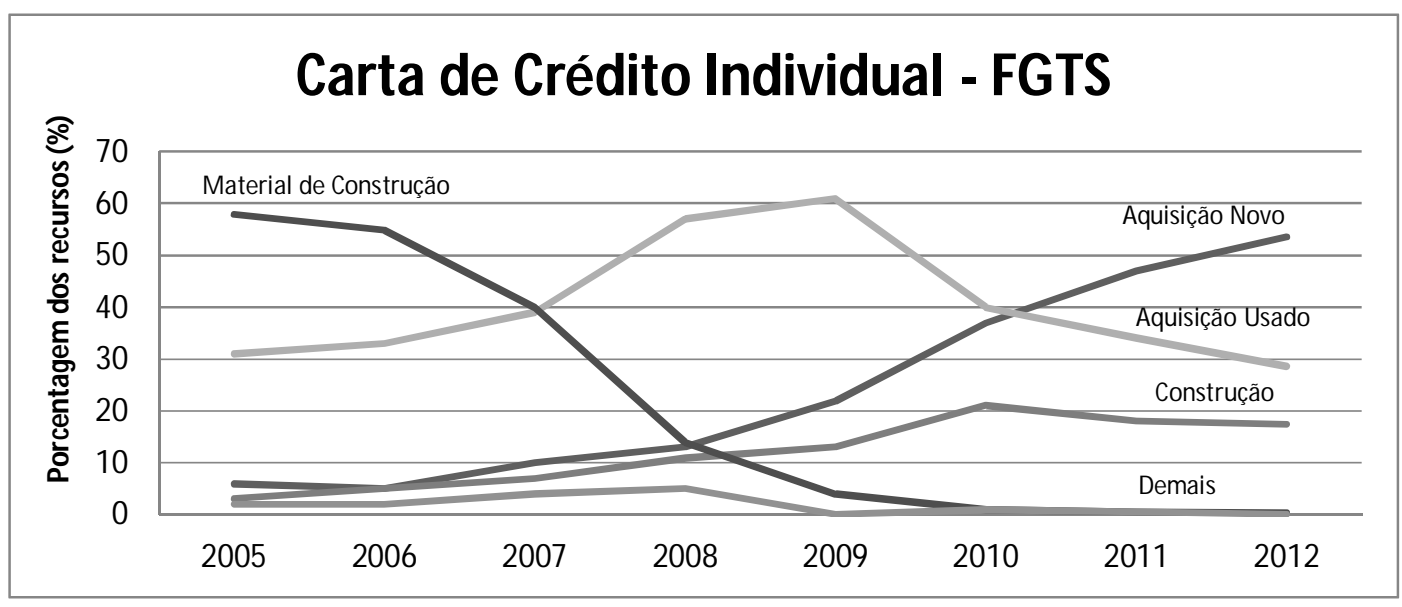

Fonte: Relatórios financeiros do FGTS e Relatórios de Gestão FGTS.

${ }^{82} \mathrm{O}$ rol de políticas era composto de: construção de unidades habitacionais, melhoria de unidades habitacionais, oferta de material de construção, oferta de lotes, regularização fundiária, aquisição de unidades habitacionais e urbanização de assentamentos. A pesquisa é baseada na declaração dos Municípios. 
O Apoio à Produção previa duas modalidades de intervenção: produção habitacional e reabilitação urbana, essa definida como "a aquisição de imóveis, conjugada com a execução de obras e serviços voltados à recuperação e ocupação para fins habitacionais, admitidas ainda obras e serviços necessários à modificação de uso." No entanto, os dados disponíveis nos relatórios de gestão (a partir de 2009) permitem concluir que a modalidade reabilitação urbana não foi realizada. Na modalidade produção foram disponibilizados recursos para 841.339 unidades até 2012, totalizando $\mathrm{R} \$$ 47.551.672.587,00. Ou seja, há uma clara escolha pelo gasto na produção e não na utilização de imóveis já existentes.

Os descontos do FGTS, que são os recursos que auxiliam no pagamento das prestações, da taxa de administração e dos juros para a população de baixa renda, criados a partir da resolução do CCFGTS n ${ }^{\circ}$ 460/2004, tiveram uma mudança de perfil depois do PMCMV. Os descontos para construção subiram e os de aquisição de cesta de material de construção caíram, porque o PMCMV foca na aquisição de imóveis novos, ou seja, unidades habitacionais com até 180 dias de "habite-se" ou que não tenham sido habitadas ou alienadas.

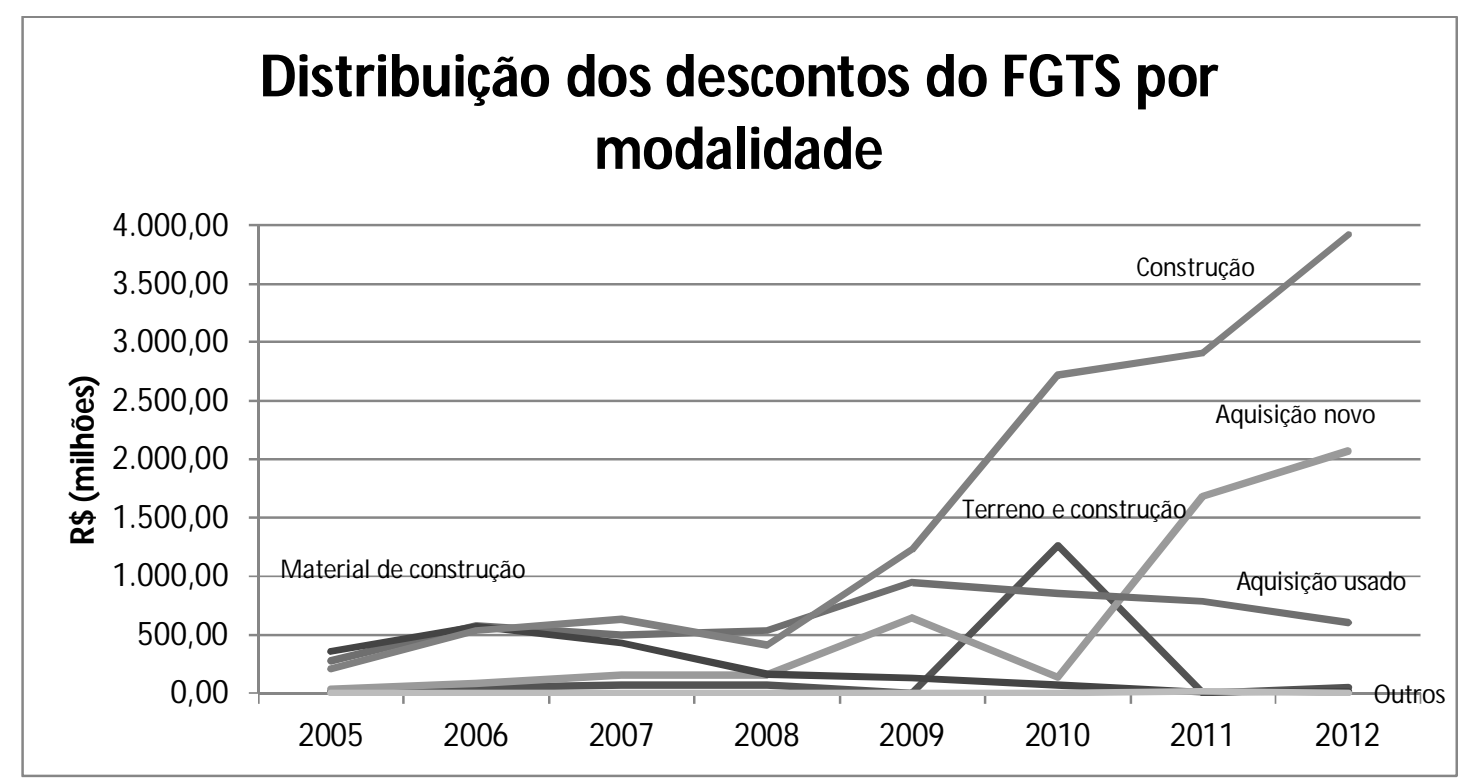

Fonte: Relatórios de Gestão do FGTS.

Os descontos dentro do PMCMV superaram, já no segundo ano do programa, os descontos fora dele: 


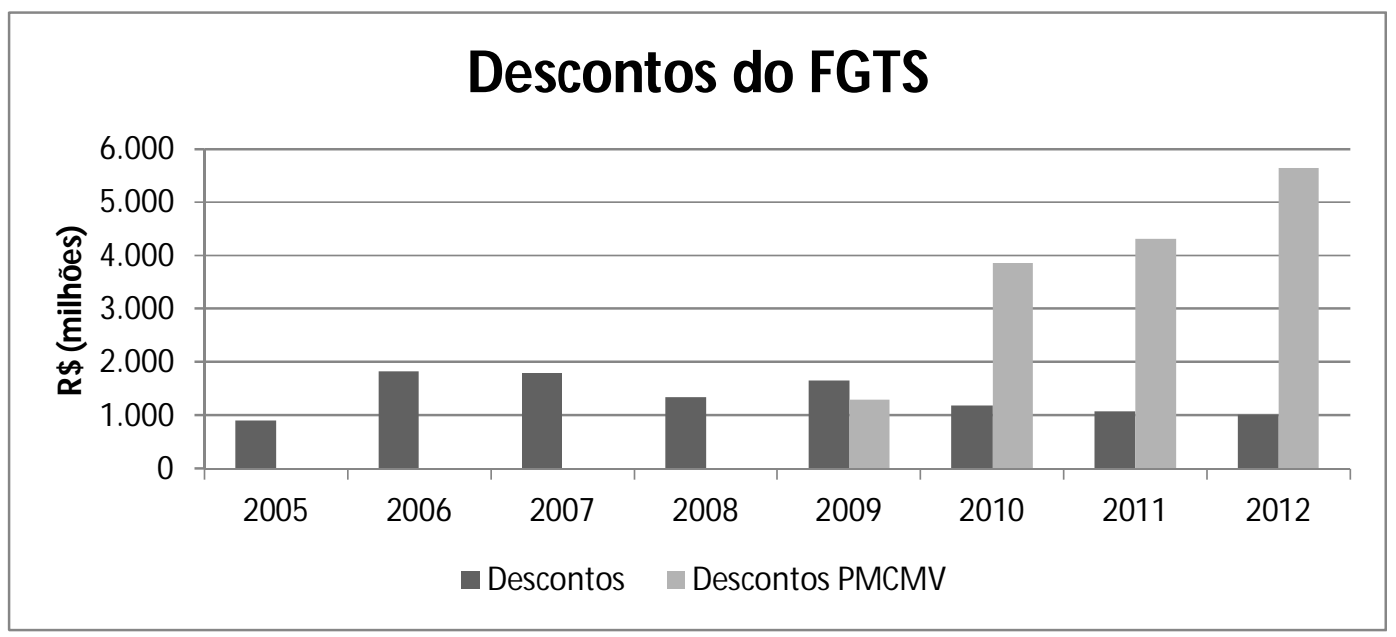

Fonte: Relatórios de Gestão do FGTS.

É possível observar que o PMCMV priorizou o modelo de construção de unidades habitacionais e financiamentos com subsídios, o que, somado ao enfraquecimento do SNHIS e do PlanHab, criou um cenário de desestímulo à diversidade nas políticas habitacionais, focando na propriedade privada individual com todas as suas limitações (Mariana F. BONATES, 2007, p. 45):

[...] a difusão da propriedade privada gera menos vantagens aos trabalhadores do que à classe capitalista (produtores imobiliários e agências financeiras), uma vez que os últimos se apropriam não apenas dos aspectos econômicos, mas também dos aspectos políticos (manutenção do status quo, principalmente). Já para os trabalhadores-proprietários, a política da casa própria proporciona, como aspecto positivo, o atendimento de uma das reivindicações da força de trabalho (a moradia), a segurança de ter sua própria moradia e a possibilidade de vendê-la ou alugá-la, obtendo uma renda.

Ainda nesse sentido, Frederico L. Burnett (2009, p. 108) discute a submissão das lutas populares a essa lógica de mercado por conta das necessidades urgentes da população mais pobre:

A produção imobiliária, seja ela de alta ou baixa renda, mantém-se assim dentro das regras do jogo que sempre dominou a constituição do espaço urbano brasileiro, mas agora toda e qualquer oposição política a ela parece estar subjugada por aquele objetivo maior, isto é, o atendimento das urgentes demandas de moradia, unindo toda a sociedade sob os interesses do mercado imobiliário, pretensamente capaz de ampliar as ofertas de postos de trabalho e o estoque de moradias populares.

As modalidades de intervenção pública no campo habitacional são múltiplas. Elas podem passar, entre outras: pela produção pública de moradias; pelo financiamento à produção e ao consumo; pela regulação da indústria da construção e do mercado 
imobiliário (compra/venda e locação); pela atividade de urbanização de novas áreas ou de áreas já ocupadas; pela intervenção no mercado fundiário; pelo controle do mercado de insumos da construção; pela tributação imobiliária; pela normatização do parcelamento, uso e ocupação do solo e da edificação. A forma de utilização desses mecanismos de intervenção depende dos objetivos do Estado, da sociedade e de quais interesses devem ser atendidos prioritariamente.

Paulo Cesar Xavier Pereira (1988, p. 3-4) aborda três pontos relevantes na estruturação da indústria da construção civil:

1) A constituição da valorização imobiliária do capital, que tende a dominar a esfera da produção e gerar desinteresse em economizar trabalho através do progresso industrial na construção. 2) A moradia, como um fenômeno cultural que expressa no uso a transformação do espaço uma segregação advinda das diferenças sociais. 3) A orientação da política pública que, desde o primeiro momento, ao privilegiar de um lado a realização de obras públicas de embelezamento e saneamento da cidade e, de outro, as facilidades do empréstimo hipotecário, ao aumentar a liquidez dos imóveis e ao inflacionar o mercado imobiliário, eleva os preços de acesso à habitação, desestimula o aperfeiçoamento técnico da indústria da construção e contribui para o agravamento da chamada questão urbana.

O destaque dado à construção civil já estava presente na exposição de motivos da

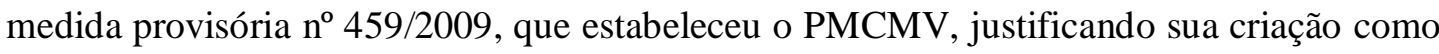
uma medida anticíclica, ou seja, uma medida de estímulo à economia, que toma forma de política social, mas que não tem como fim prioritário a redução do déficit habitacional:

De fato, diante do cenário de crise financeira mundial com o recrudescimento de seus impactos negativos sobre a atividade econômica, renda e nível de emprego do País é premente a necessidade de adoção de medidas de natureza anticíclicas no curto prazo, principalmente aquelas que possam garantir a melhoria da qualidade de vida da população de baixa renda e a manutenção do nível de atividade econômica.

Essa priorização da construção prejudica o aproveitamento do espaço urbano com infraestrutura que se encontra desocupado, já que o objetivo da política é o aquecimento do setor da construção civil por meio da edificação de novas unidades habitacionais.

Sob essa perspectiva, cabe lembrar a relevância dos vazios urbanos: utilizando dados do Censo de 2000, um estudo de Vanessa G. Nadalin e Renato Balbim (2011, p. 13) identificou que nas regiões metropolitanas (RMs) mais ao Norte, à exceção de Salvador/BA, há mais déficit habitacional que domicílios vagos (Recife/PE, Distrito 
Federal, Fortaleza/CE e Belém/PA); no entanto, as RMs mais ao sul têm relação inversa com predominância de domicílios vagos sobre o déficit habitacional (Rio de Janeiro/RJ, Curitiba/PR, Porto Alegre/RS, Belo Horizonte/MG e Salvador/BA), sendo que no Rio de Janeiro a proporção chega a 152,59\%. Relacionando dados espaciais, os pesquisadores concluíram que na RM de São Paulo (NADALIN; BALBIM, 2011, p. 13): “[...] verifica-se que nas áreas mais centrais, onde predomina o crescimento negativo da densidade demográfica, foi encontrada uma aglomeração de taxas de vacância altas. O movimento inverso ocorre nas áreas mais periféricas."

Segundo o censo de 2010, havia pelo menos 6.097 .778 domicílios particulares $\operatorname{vagos}^{83}$, ou seja, imóveis que têm potencial para auxiliar no combate ao déficit habitacional no país e que não são priorizados pela política eleita pelo governo central como a concentradora de recursos.

\subsection{Repartição de recursos: SNHIS}

Uma das ressalvas às contas do governo em 2006 feitas pelo Tribunal de Contas da União (TCU, 2006, p. 316) foi: “[...] não alocação em 2006, no Siafi, dos créditos orçamentários do fundo Nacional de Habitação de Interesse Social - FNHIS, no órgão e na unidade gestora próprios do Fundo, o que inviabilizou a execução dos recursos no exercício." Posteriormente foram criadas por meio da lei $\mathrm{n}^{\circ} 11.306 / 2006$ as unidades orçamentárias "Fundo Nacional de Habitação de Interesse Social" e "Recursos sob Supervisão do Fundo Nacional de Habitação de Interesse Social”. Em 2007, segundo o TCU (2007, p. 384):

[...] as dotações foram integralmente alocadas no órgão do Fundo no montante de R\$ 1 bilhão, concentrando a quase totalidade das dotações orçamentárias classificadas na função Habitação (outros R\$ 1,6 milhões foram consignados no próprio Ministério das Cidades, que nada executou). O montante da despesa executada pelo FNHIS foi de R\$ 600 milhões, dos quais pouco mais da metade, R\$ 301 milhões, referem-se a transferências voluntárias a estados e municípios.

De acordo com Cardoso (2013), havia um compromisso do presidente em alocar 1 bilhão de reais por ano no fundo.

\footnotetext{
${ }^{83}$ Esse número não inclui domicílios ocupados em que não foi realizada a entrevista e domicílios não

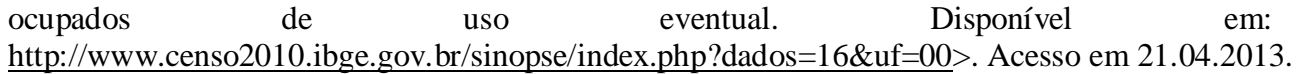


A distribuição dos recursos do fundo foi desigual no território, no estudo do IPEA (2011, p. 17) se discute os resultados:

Sete estados têm mais de $50 \%$, enquanto quatro têm menos de $25 \%$ de seus municípios contemplados. Entre as capitais estaduais, não foram selecionadas somente cinco. Apenas 28 municípios com 100 mil ou mais habitantes, incluindo capitais, não foram selecionados - aproximadamente $11 \%$ dos municípios brasileiros nessa faixa de população. Por outro lado, 3.058 municípios com população inferior a 20 mil habitantes e fora de regiões metropolitanas aderiram ao SNHIS, mas não receberam seleção do FNHIS para elaboração do plano habitacional.

Um dos problemas deste trabalho é a falta de informações sobre os pedidos indeferidos e a justificativa, decisão interna ao ministério em que falta transparência, considerando ainda que, apesar de haver critérios para as escolhas, os remanejamentos são permitidos.

Segundo os dados atualizados até abril de 2013 fornecidos pelo Ministério das Cidades em resposta às informações solicitadas pela autora, os dados do FNHIS foram classificados em PAC e não-PAC. Os recursos não PAC, que somaram $\mathrm{R} \$ 1.319 .202 .574,05$ em repasses, foram aplicados em 1.093 operações, em 822 Municípios, em todos os Estados da federação de 2006 a 2012, com as contrapartidas o investimento foi de $\mathrm{R} \$ 1.740 .775 .166,06$, com variações de $\mathrm{R} \$ 9.750,00$ a $\mathrm{R} \$ 54.039 .400,02$ no valor dos repasses e sem especificação sobre o ente que solicitou os recursos do fundo. O Programa de Urbanização, Regularização e Integração de Assentamentos Precários representou $73 \%$ do total dos repasses, sendo que o restante se relacionou com o Programa de Habitação de Interesse Social. O volume de recursos foi maior no Programa dos Assentamentos Precários porque o valor médio de repasse nele é maior: R \$ 3.095.039,44 com 312 operações, em vista de: $\mathrm{R} \$ 452.689,21$ para Habitação de Interesse Social com 781 operações. Infelizmente, os dados não revelam o número de unidades habitacionais ou de beneficiados.

Diversos contratos foram distratados ou cancelados, no entanto, a análise os engloba porque a seleção, que é anterior ao problema, indica aspectos do perfil dos Municípios que receberam, ou deveriam receber recursos do governo central. Dos 1.093 contratos: 358 foram cancelados, 16 foram cancelados por erro de cadastramento, cinco foram cadastrados com cláusula suspensiva, 45 foram distratados, seis tiveram restrição cadastral em função de liminar judicial, 21 constavam como tomadas de contas especiais do TCE e 642 estavam em situação normal. 
Nos anos de 2011 e 2012 não foram selecionados repasses para o programa de assentamentos precários $\mathrm{e}$ foi bastante reduzida a quantia fora do PAC:

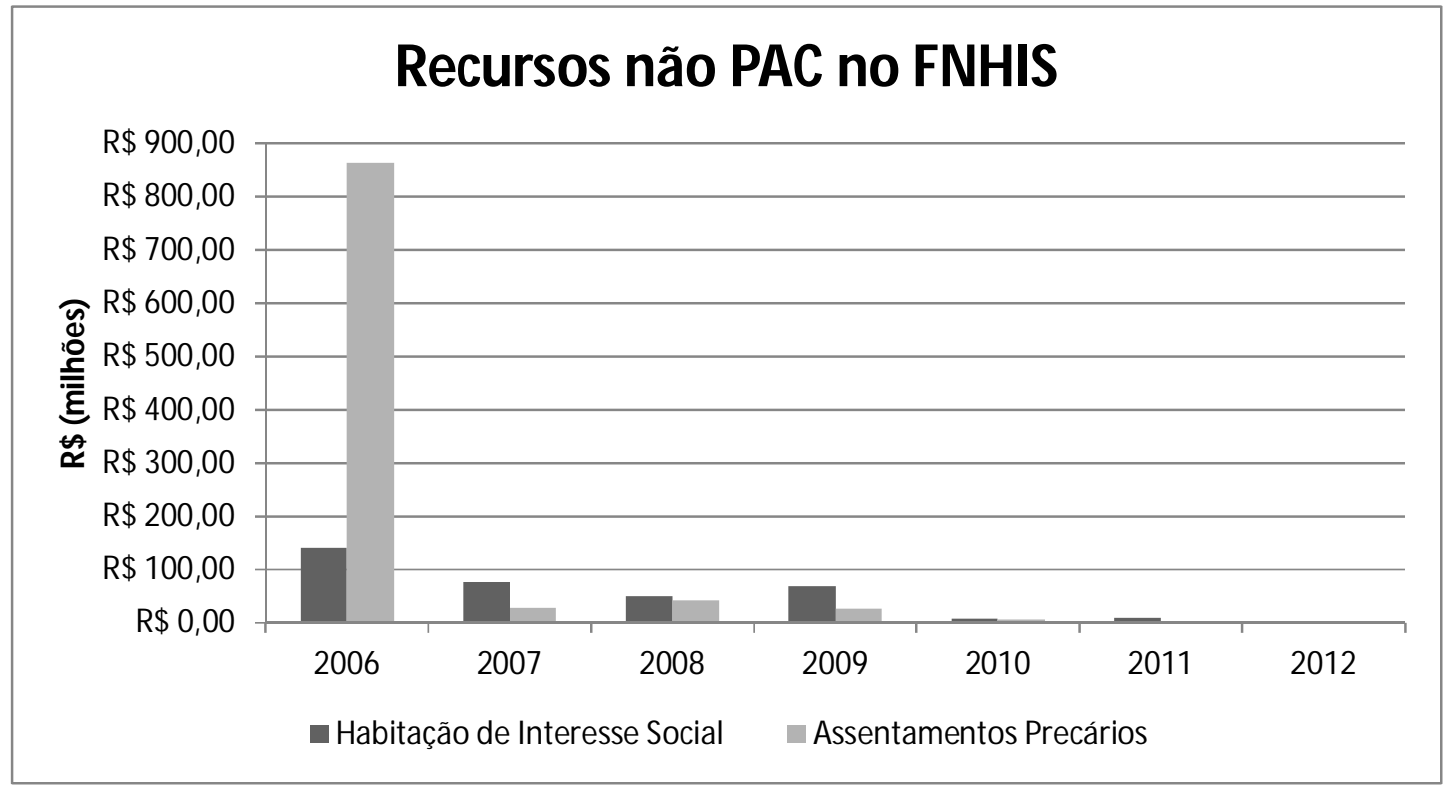

Fonte: resposta ao pedido de informações formulado pela autora.

O repasse do FNHIS PAC foi de $\mathrm{R} \$ 4.001 .460 .315,13$, valor aplicado em 4.554 operações, distribuídas por 2.028 Municípios em todos os Estados de 2007 a 2010, sendo que $30 \%$ foi destinado à Habitação de Interesse Social (assistência técnica, lotes urbanizados, planos locais, provisão habitacional, requalificação de imóveis e estudos e (R\$960.450.705,20) e Urbanização de Assentamentos Precários R\$2.803.224.789,81:

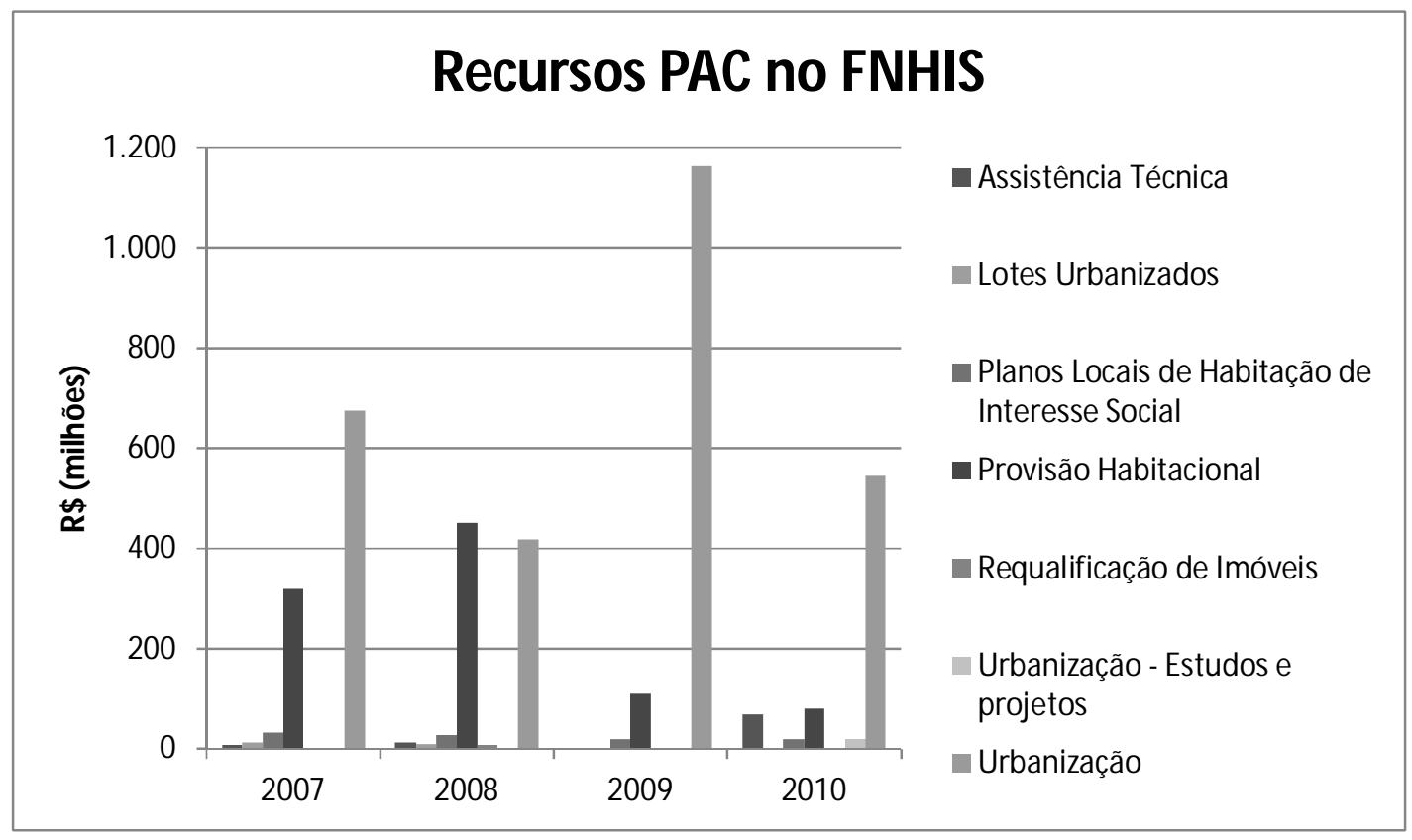

Fonte: resposta ao pedido de informações formulado pela autora. 
O programa que teve a maior capilaridade foi o de Planos Locais de Habitação de Interesse Social, que atingiu 1.878 repasses, seguido do programa de Provisão Habitacional (1.118), do programa de Assistência Técnica (898) e do programa de Urbanização (539). Os pedidos foram realizados por Municípios, Estados e entidades sociais: 3.792, 531 e 231 repasses, respectivamente.

Enquanto 1.558 dos contratos estavam concluídos e 1.610 normais, 1.364 foram distratados, 17 constavam como tomada de contas especial TCE e cinco foram contratados com cláusula suspensiva. Os Estados que mais receberam recursos nessa ordem foram: do Sudeste (SP, RJ e MG), Nordeste (BA) e Sul (RS).

Os dados fornecidos também permitem observar uma diminuição nos recursos selecionados nos últimos anos ${ }^{84}$, o que indica uma tendência de enfraquecimento do fundo, reduzindo seu poder de influenciar decisões dos entes federados e confirmando o abandono do sistema como concentrador dos recursos para habitação.

\section{O enfraquecimento do SNHIS}

O SNHIS não conseguiu se consolidar, sua trajetória foi abortada precocemente e o surgimento do PAC e do PMCMV auxiliou nesse processo de enfraquecimento.

A resolução nº 9/2007 do CGFNHIS pela primeira vez menciona, na Ação de Apoio ao Desenvolvimento e à Qualificação da Política Habitacional, o apoio aos entes para a implementação do PAC. Na resolução nº 18/2008, a Ação Apoio à Produção Social da Moradia tem como diretriz geral a integração com programas da União.

Já a resolução no 27/2009 explicitamente subordina o FNHIS ao PAC e ao PMCMV: "Considerando a necessidade de ajustar os critérios de execução dos programas do FNHIS às diretrizes do Programa Minha Casa, Minha Vida, de que trata a medida provisória $\mathrm{n}^{\mathrm{o}} 459$, de 25 de março de 2009 , e considerando a necessidade de viabilizar a complementação de projetos inseridos no Programa de Aceleração do Crescimento PAC".

A definição das porcentagens de recursos divididos por programas varia nas resoluções: na de $n^{\circ}$ 10/2007 os assentamentos precários teriam 40\% dos recursos nos períodos de 2008/09 e 2010/11, 45\% seriam destinados à ação de Apoio à Provisão

\footnotetext{
${ }^{84}$ Não existem recursos selecionados após 2010 nos dados enviados a pedido da autora atualizados até abril de 2013.
} 
Habitacional e o restante para assistência técnica, formulação de planos e para o desenvolvimento e qualificação da política habitacional. Na resolução $n^{\circ}$ 18/2008 surge uma nova ação: produção social da moradia, que passa a contar com $10 \%$ dos recursos, a provisão habitacional permanece com $45 \%$, os assentamentos precários com $40 \%$ e os $5 \%$ restantes para planos, qualificação e assistência técnica.

Mais relevante é a mudança trazida pela resolução no 27/2009: a ação de Apoio à Provisão Habitacional, que era a que tinha mais recursos na res. $n^{\circ} 10 / 2007$, desaparece da distribuição percentual de recursos. Ela não é eliminada declaradamente, mas esvaziada, restando concentrado o orçamento na Ação Melhoria das Condições de Habitabilidade de Assentamentos Precários com $87 \%$ do total.

A resolução seguinte $n^{\circ} 28 / 2009$ subordina a ação apoio à produção social da moradia às regras do MCMV. A resolução $n^{\circ}$ 29/2009 modifica, mais uma vez, a distribuição de recursos passando a ação de melhoria das condições de habitabilidade a utilizar $90,23 \%$ do total, cabendo $3,76 \%$ à produção social, $1,5 \%$ aos planos e 4,5\% à assistência técnica. A resolução n ${ }^{\circ}$ 33/2010 possibilitou a apresentação de propostas apenas para a ação de melhoria dos assentamentos precários e para a assistência técnica para o ano de 2010, eliminando as outras possibilidades de acesso aos recursos. Por fim, a resolução n 42/2011 cria novos programas para o PPA do fundo para o período de 2012-2015, mas ainda estabelece a previsão da ação de provisão habitacional, que havia deixado de ser autorizada no fundo.

O gráfico a seguir mostra a variação na definição da porcentagem de recursos para as ações do FNHIS. Apesar de não pertencerem exatamente ao mesmo período, todas as resoluções dizem respeito ao período do PPA 2008-2011.

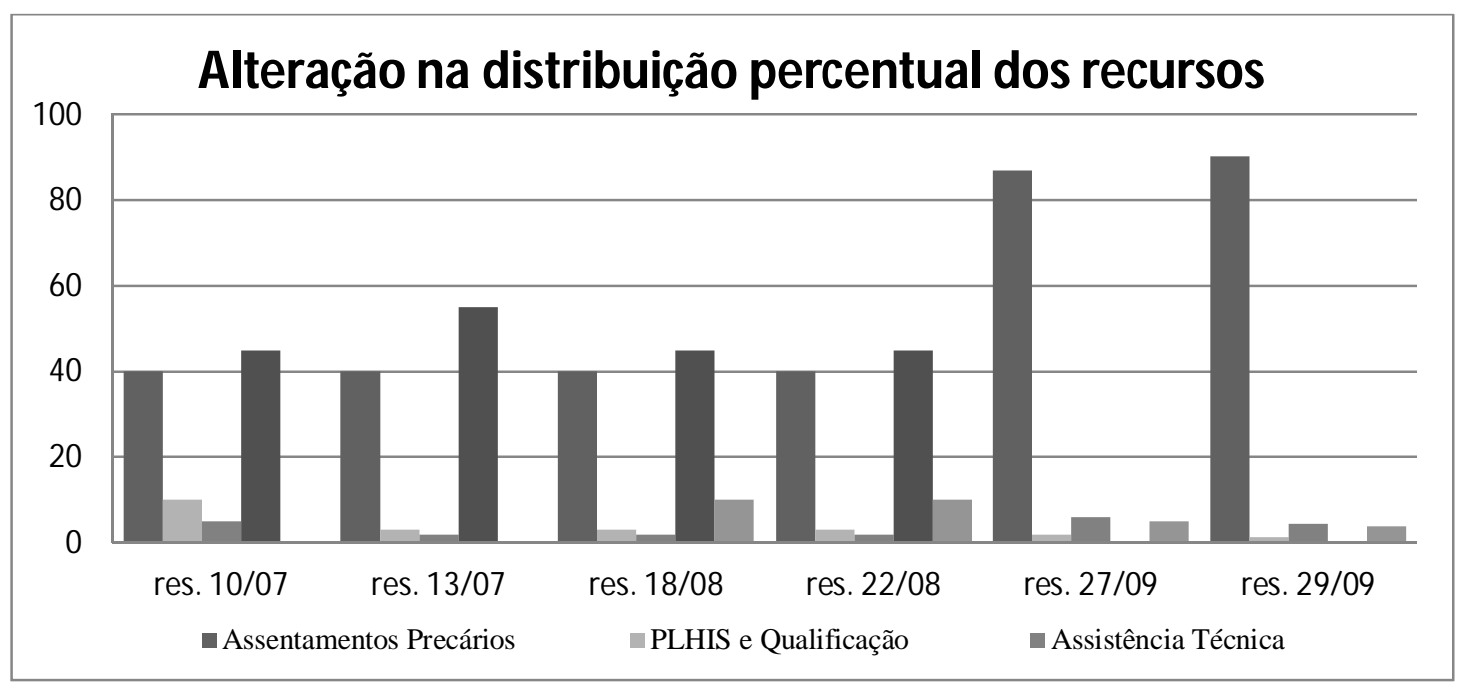

Fonte: elaboração própria de acordo com as resoluções do CGFNHIS. 
É possível observar, portanto, que o CGFNHIS, por meio de suas resoluções, possibilitou o esvaziamento do FNHIS para a provisão habitacional, ao mesmo tempo que ampliou o percentual de gastos em assentamentos precários sob a lógica do PAC. Resoluções, portarias e instruções normativas foram delineando os programas habitacionais e, juntamente com as decisões sobre os recursos, modificaram a lógica da política pública que estava estruturada legalmente.

Desde o lançamento do Programa Minha Casa, Minha Vida, observa-se que as diretrizes de longo prazo foram abandonadas em prol de uma política anticíclica com viés de política econômica e não política social (CARDOSO et al., 2011, p. 4-5):

Considerando o desenho adotado para o programa, fortemente ancorado na participação do setor privado, o PMCMV entrou em choque com os princípios do SNHIS: pautado no papel estratégico do setor público, ignorou em larga medida premissas e debates acumulados em torno do Plano Nacional de Habitação de Interesse Social - PlanHab, então amplamente discutido desde 2007. Um dos impactos mais imediatos sobre os programas desenvolvidos no âmbito do FNHIS diz respeito à eliminação dos repasses de recursos para as ações de provisão habitacional. Desde o lançamento do PMCMV, o FNHIS passou a concentrar os seus recursos nas ações de urbanização de assentamentos precários e de desenvolvimento institucional, por orientação do MCid acatada pelo Conselho Gestor.

\subsection{Dinheiro fora do FNHIS}

Segundo a lei $n^{\circ} 4.320 / 1964$, a lei do orçamento deverá ser integrada pelo sumário geral da despesa por funções ${ }^{85}$ do Governo (art. $\left.2^{\circ}, \S 1^{\circ}, I\right)$, classificação que se relaciona com a missão institucional do órgão. Segundo a portaria no 42, de 14 de abril de 1999 do Ministério do Orçamento e Gestão, a função habitação (código: 16) está dividida entre Habitação Rural (código 481) e Habitação Urbana (código 482). O FNHIS tem centralizado os recursos da função 'habitação' do orçamento do governo federal: com exceção de 2008, em todos os anos, de 2006 a 2011, os valores pagos são coincidentes.

\footnotetext{
${ }^{85}$ A classificação funcional é composta de um rol de funções e subfunções (portaria SOF 42/1999) e serve como agregador de gastos públicos por área de ação governamental. De acordo com o Manual Técnico de Orçamento (MTO), a função pode ser traduzida como o maior nível de agregação das diversas áreas de atuação do setor público e está relacionada com a missão institucional do órgão, por exemplo: cultura, educação, saúde, defesa, que guarda relação com os respectivos ministérios. A subfunção, nível de agregação imediatamente inferior à função, deverá evidenciar cada área da atuação governamental, ainda que esta seja viabilizada com a transferência de recursos a entidades públicas e privadas.
} 
No entanto, o Programa Minha Casa, Minha Vida se utilizou da função 'Encargos Especiais ${ }^{86}$, não se relacionando com o FNHIS ou com a função habitação (TCU, 2010, p. 285):

Quanto ao PMCMV, não há correlação direta com um programa orçamentário. Sua execução se deu, nos primeiros dois anos, dentro do programa orçamentário Operações Especiais - Outros Encargos Especiais, por meio de cinco ações que atendem às diferentes modalidades do PMCMV: (i) Transferência ao Fundo de Arrendamento Residencial - FAR; (ii) Subvenção econômica destinada a implementação de projetos de interesse social em áreas urbanas; (iii) Subvenção econômica destinada a implementação de projetos de interesse social em áreas rurais; (iv) Subvenção econômica destinada à Habitação de Interesse Social em cidades com menos de 50.000 habitantes; e (v) Transferência ao Fundo de Desenvolvimento Social - FDS. Conforme consignado na primeira tabela, em 2010 foram liquidados, na soma das ações, $\mathrm{R} \$ 1$ bilhão, cerca de metade dos valores liquidados em 2009.

Desse modo, além dos recursos extraorçamentários nas políticas habitacionais, cujos destinos são direcionados pelos respectivos conselhos (CMN e CCFGTS), o maior programa habitacional também não se relacionou com a função orçamentária habitação, que deveria ser concentrada no FNHIS.

\subsection{PAC}

O Programa de Aceleração do Crescimento (PAC), assim como o PMCMV, recebeu tratamento prioritário em relação ao SNHIS, que teve parte dos seus recursos direcionados aos programas do governo federal, conforme Cardoso et al. (2011, p. 5):

De acordo com o volume de recursos alocados e com a dinâmica de execução adotada, aponta-se que o PAC Habitação causará um primeiro deslocamento na centralidade do FNHIS na política habitacional. Inclusive do ponto de vista simbólico, visto que o PAC passa a ser uma label que submete à sua ordem todos os programas governamentais com impacto no crescimento econômico, entre eles o FNHIS. Para gestores da Secretaria de Habitação, esta subordinação representava ganhos expressivos, pois recursos alocados na rubrica do PAC não estariam sujeitos a contingenciamentos. Diferentemente dos recursos do FNHIS,

\footnotetext{
${ }^{86}$ Portaria no 42/1999: Art. $1^{\circ}$, §2 A função "Encargos Especiais" engloba as despesas em relação às quais não se possa associar um bem ou serviço a ser gerado no processo produtivo corrente, tais como: dívidas, ressarcimentos, indenizações e outras afins, representando, portanto, uma agregação neutra.
} 
no entanto, os do PAC não estavam atrelados a quaisquer mecanismos de controle social ou a critérios institucionais de redistribuição, sendo a sua alocação prerrogativa exclusiva da Casa Civil da Presidência da República.

O relatório do TCU (2008, p. 190) sobre as contas do governo aponta que os gastos na subfunção "Habitação Urbana" tiveram forte crescimento em 2008, cerca de $180 \%$, motivado pelos programas que a compõem e que estão entre as atribuições do PAC."

O Conselho das Cidades nas resoluções $n^{\circ}$ 93/2010 e $n^{\circ} 114 / 2011$ trata do relacionamento entre PAC, PMCMV e SNHIS. A resolução nº 93/2010, considerando que por meio de programas habitacionais federais como o PAC e o PMCMV são repassados vultuosos recursos aos entes federados, recomenda que somente haja esse repasse de recursos se houver a adesão ao sistema com a aprovação do plano e instituição do conselho no ente beneficiado. A resolução $n^{\circ}$ 114/2011 recomenda a transferência dos recursos do Orçamento Geral da União (OGU) do PAC Habitação para o FNHIS para a garantia do controle social.

A segunda fase do PMCMV foi inserida no PAC (IPEA, 2013, p.8):

[...] a partir de 2011, em sua segunda fase, o MCMV foi incluído no PAC, sugerindo que a política habitacional tenha passado a responder mais fortemente às estratégias de alavancagem do desenvolvimento do país - aceleração do crescimento -, sendo a habitação o produto entregue desta política de desenvolvimento, e não necessariamente o contrário, como se poderia esperar.

\subsection{Programa Minha Casa Minha Vida}

O Programa Minha Casa Minha Vida (PMCMV) foi instituído pela medida provisória (MP) $n^{\circ} 459 / 2009$, convertida na lei $n^{\circ} 11.977 / 2009$, que, por sua vez, foi alterada pela MP $\mathrm{n}^{\circ} 514 / 2010$, convertida na lei $\mathrm{n}^{\circ} 12.424 / 2011$

Num contexto de crise econômica internacional, o programa acabou sendo priorizado em detrimento da consolidação de um setor habitacional para a população de baixa renda, subordinando a estrutura que vinha sendo desenvolvida com alguma participação da sociedade civil e algum planejamento, como aborda Fix (2011, p. 140):

Entre seminários, oficinas e reuniões técnicas realizaram-se mais de 60 atividades participativas, que reuniram governos estaduais e municipais, movimentos populares e profissionais, para a elaboração do Planhab. O MCMV, entretanto, foi elaborado sob liderança da Casa Civil e do Ministério da Fazenda, em diálogo direto com representantes da construção, e sem participação popular. A estrutura operacional do Ministério das Cidades, que articula as políticas de habitação, saneamento, transportes e desenvolvimento urbano, não foi 
mobilizada na concepção do pacote. O Conselho das Cidades, órgão deliberativo do Mistério, não foi consultado. O Fundo Nacional de Habitação de Interesse Social, que deveria concentrar todos os recursos da política habitacional de modo a uniformizar os critérios de acesso, ficou também fora do MCMV, exceto na modalidade - Entidades, restrita a 1,5\% do subsídio público. Diferentemente, o pacote direciona os recursos para um fundo público secundário e sem conselho, o Fundo de Arrendamento Residencial (FAR), mais maleável e desregulado, utilizado para a faixa de 0 a 3 salários mínimos.

O modelo do PMCMV priorizou a atuação dos empresários, conforme observa Dias (2012, p. 87):

Com o lançamento do PMCMV, em 2009, a linha de frente da política habitacional passa a ser a construção de moradia social a partir de projetos propostos, viabilizados e executados por construtoras, com subsídios diretos na prestação decrescentes de acordo com as faixas de renda.

Desse modo, a habitação é usada mais como discurso legitimador do que como objetivo da política pública, segundo Fix (2011, p. 141):

O Minha Casa Minha Vida alçou a habitação a — problema nacional de primeira ordem, mas o definiu segundo critérios do capital, ou da fração do capital representada pelo circuito imobiliário, e do poder, mais especificamente, da política eleitoral. O programa articula um problema social real e importante, a falta de moradias dignas, à mobilização conformista do imaginário popular e aos interesses capitalistas. Responde, a um só tempo, a problemas de acumulação, por meio da injeção de recursos no circuito imobiliário (construção de edificações e construção pesada, indústria de materiais e componentes, mercado de terras) e legitimação, ao responder à pressão das lutas sociais do ponto de vista da demanda por habitação e por emprego. Guardadas as diferenças - sem dúvida significativas e importantes - são claros os paralelos com a história do $\mathrm{BNH}$.

Nesse sentido também a conclusão do IPEA (2013, p. 46) de que não se trata exclusivamente de uma política habitacional: “[...] conseguimos revelar com forte segurança que o MCMV tem fraca aderência às estratégias de enfrentamento do déficit habitacional, o que o distancia num primeiro momento de uma política habitacional stricto sensu, especialmente de habitação de interesse social."

O descolamento entre o discurso e a prática da política habitacional fica clara com a distribuição das unidades a serem produzidas, a faixa que concentra o déficit tem somente $40 \%$ dos recursos destinados a ela na primeira fase do programa: 


\begin{tabular}{cccc}
\hline Faixa & $\begin{array}{c}\text { Déficit } \\
\text { Urbano }\end{array}$ & MCMV 1 & MCMV 2 \\
\hline Faixa 1 & 4.148 .329 & 400.000 & 1.600 .000 \\
\hline Faixa2 & 379.646 & 400.000 & 600.000 \\
\hline Faixa 3 & 74.077 & 200.000 & 200.000 \\
\hline Acima de 10 & 27.779 & 0 & 0 \\
\hline Total & 4.629 .831 & 1.000 .000 & 2.400 .000 \\
\hline Fonte: Rodrigues, 2013. & &
\end{tabular}

Se o Programa Minha Casa, Minha Vida é prioridade do governo federal, ele está dividido por prioridades também: a parcela do programa voltado à construção por entidades sem fins lucrativos recebe muito menos dinheiro que a fração voltada ao setor empresarial (LAGO, 2011, p. 8):

De 2009 a março de 2011, o Programa MCMV Entidades realizou a contratação de 9.001 unidades, no valor total de $\mathrm{R} \$ 440$ milhões. [...] Para a produção empresarial, vimos anteriormente que o Programa financiou, em menos de dois anos, 449 mil unidades, segundo dados da Caixa.

O PMCMV é dividido por faixas de renda, sendo que a mais baixa ${ }^{87}$ (até $\mathrm{R} \$ 1.395,00^{88}$ ) tem acesso a recursos do Fundo de Desenvolvimento Social (previsão de R \$500mi na lei $\left.\mathrm{n}^{\circ} 11.977 / 2009\right)$ e, especialmente, do Fundo de Arrendamento Residencial (previsão de $\mathrm{R} \$ 16$ bi na lei $\mathrm{n}^{\circ}$ 11.977/2009): “Até 31.12.2012, o FAR contratou, para o PMCMV, 2.308 empreendimentos totalizando 793.988 unidades habitacionais, no valor total de R\$39.331.814.395,75." (CAIXA. FAR, 2013, p. 46). “Até 31.12.2012, foram concluídos 940 empreendimentos com 273.167 unidades habitacionais e contratada a alienação de 248.623 unidades." (CAIXA. FAR, 2013, p. 51).

Por conta do PMCMV, o FAR, que era ligado ao Programa de Arrendamento Residencial (PAR) criado pela lei $\mathrm{n}^{\mathrm{o}} 10.188 / 2001$, foi usado como fonte de recursos do novo programa. O PMCMV modificou o Programa de Arrendamento Residencial: em 2012 foi entregue apenas um empreendimento e não foram mais adquiridos imóveis para arrendamento, direcionando os recursos do FAR para o novo programa.

A lei do FAR já tinha sido alterada para permitir a alienação sem o arrendamento prévio: “A Medida Provisória nº. 350/2007, convertida na Lei nº 11.474/2007, editada no âmbito do Plano de Aceleração do Crescimento - PAC autorizou a alienação dos imóveis

\footnotetext{
${ }^{87}$ Mesmo no caso de programas destinados a população de baixa renda, abriu-se oportunidades de elevação desse limite de renda em casos de calamidade pública ou obras relacionadas ao PAC com remanejamento ou substituição de habitações (decreto n ${ }^{0} 7.795 / 2012$ ).

${ }^{88}$ No Programa Nacional de Habitação Rural (PNHR) a renda é calculada por ano.
} 
sem prévio arrendamento e a desmobilização patrimonial do FAR." (BRASIL. MCIDADES. CEF, 2010, p. 43).

De fato, o PMCMV se tornou predominante, superando o número de unidades de toda a história do PAR: "Em aproximadamente 4 anos o número de unidades habitacionais destinadas à venda direta aos beneficiários do PMCMV superou em 190,68\% o total de unidades adquiridas ao longo de 10 anos para fins de arrendamento no âmbito do PAR." (CAIXA. FAR, 2013, p. 78).

O PMCMV também modificou a utilização do Programa Crédito Solidário, já que a versão Entidades concorre com esse programa no FDS (FDS, 2010, p.17-20):

Já no PCS foram utilizados R 1,2 milhões, 1,5\% do total de R 80 milhões disponíveis. Percentual inferior ao utilizado em 2009, que foi de $39,18 \%$ do total de R\$ 100 milhões disponíveis. Esse resultado é explicado pelo direcionamento dos projetos para o PHP-E-MCMV cujas condições são melhores para os beneficiários. [...] No exercício de 2010 não houve seleção de proposta no PCS, uma vez que as entidades interessadas na contratação de financiamentos, com recursos do FDS, optaram pelo PHP-E-MCMV onde as condições de financiamento são mais benéficas para o beneficiário final. Foi contratada somente uma proposta selecionada no exercício anterior.

Mesmo a população que conta com as menores rendas do programa deve pagar prestações mensais (mínimo de $\mathrm{R} \$ 25,00$ segundo o decreto $\mathrm{n}^{\mathrm{o}} 7.795 / 2012$ ), exceto se a necessidade habitacional decorreu de obras com recursos federais como as do PAC ou de situações de emergência. É importante destacar que o programa não se resume a construção de unidades habitacionais, mas há financiamentos isolados de unidades já prontas ou a serem construídas isoladamente.

As prestações, os limites de renda e outras determinações são decididas pelo Ministério das Cidades, Ministério da Fazenda e Ministério do Orçamento, Planejamento e Gestão. Já o monitoramento do programa é realizado pelo Comitê de Acompanhamento do Programa Minha Casa, Minha Vida-CAPMCMV formado pela Casa Civil, além dos ministérios já mencionados.

Os critérios nacionais para seleção dos candidatos são três: famílias desabrigadas ou em àreas de risco, com pessoas com deficiência ou nas famílias em que a mulher é responsável pela entidade familiar. Os entes federados e as entidades podem estabelecer mais critérios, que devem ser aprovados pelos conselhos, desde que respeitem os critérios federais. O papel dos entes fica limitado à seleção dos beneficiários em algumas 
modalidades do programa e aos trabalhos pós ocupação, além das mudanças pontuais na legislação tributária e urbanística.

O PMCMV impõe em seu termo de adesão que todos os atos de publicidade devam divulgar exclusivamente o programa, mesmo que a publicidade seja custeada pelo ente. Deve ser utilizado o Manual de Criação e Uso da Logomarca do PMCMV, segundo a portaria $n^{\circ}$ 24/2013 do Ministério das Cidades, sob pena de rescindir os termos de adesão firmados e impedir novos contratos.

O programa estabelecia anteriormente que o limite de renda para os beneficiários era de até 10 salários mínimos, mas, a partir da lei n 12.424/2011, passou a ser um valor: $\mathrm{R} \$ 4.650,00$ para todo o país. Nas áreas urbanas, os critérios de priorização estabelecidos pela lei são: doação de terrenos pelos entes federados, desoneração tributária para as construções destinadas à habitação de interesse social e a implementação de instrumentos de combate a ociosidade de áreas urbanas. Com a priorização de terrenos doados, que permitem a produção para a população de mais baixa renda, e tendo o modelo do programa se baseado no interesse de agentes privados, é possível haver a concentração de empreendimentos em determinados Municípios e regiões, mesmo que descolados da necessidade habitacional da localidade, conforme observa pesquisa do IPEA (2013, p. 29):

Assim, o MCMV-HIS, ao privilegiar a execução em determinadas áreas que guardam maior interesse ou facilidade para produção de UHs, parece responder mais fortemente à necessidade de dinamização econômica por meio da execução exclusiva de metas físicas, não necessariamente providas dos demais critérios relacionados às necessidades habitacionais, ou mesmo critérios urbanísticos, arquitetônicos, sociais, culturais e demográficos citados e utilizados pelo PlanHab. Neste sentido o MCMV pode estar agudizando problemas migratórios e urbanísticos, em especial de mobilidade, de acesso a equipamentos e serviços e, em última análise, de expansão do perímetro urbano baseada exclusivamente na produção habitacional, e não num projeto de cidade.

Por outro lado, o preço e a disponibilidade da terra em alguns Municípios limitou a oferta de terrenos para o programa para a população de renda mais baixa, conforme analisa Ipea (2013, p. 47):

O exame comparado da distribuição da produção de empreendimentos do MCMV com distintas fontes de recursos e faixas de renda denota a agudização de problemas de ordem fundiária nas maiores cidades do país, uma vez que são vários os casos em que é pequena a produção de UHs de menor custo pelo FAR em municípios-núcleo de metrópoles, dispondo-se nesses municípios as unidades 
de maior valor financiadas pelo FGTS e fazendo com que as demais tendam a ser deslocadas para municípios periféricos.

Conforme observação de Evaniza Rodrigues (2013, p. 141-2) acerca das limitações do programa:

O MCMV tem sido apontado como indutor de um boom no aumento preço dos terrenos para habitação. Por isso, houve pressão do setor da construção civil e o programa, na Faixa 1, já registra três reajustes no valor do teto de financiamento, desde o seu lançamento, em 2009. Essa fórmula tem caraterística autofágica, já que a cada aumento do teto do programa, na ausência de qualquer política fundiária, novamente aumenta o preço dos terrenos.

O problema pode estar no mau direcionamento da política, que perpetua a necessidade habitacional ao invés de combatê-la. Conforme estudo do IPEA (2013, p. 35), se o direcionamento fosse ao déficit ele estaria resolvido na faixa superior da renda: "o número de UHs contratadas pelo MCMV/FGTS em 12 de junho de 2012 já era de aproximadamente 488 mil, em comparação com cerca de 454mil famílias com renda entre três e dez SMs em situação de déficit habitacional urbano, conforme estimativa mais recente (2008)."

Em publicação sobre o assunto (CARDOSO et al., 2013), diversos autores fazem uma análise crítica do programa em localidades pelo país. Constatou-se que em alguns casos: a construtora obteve financiamento para uma faixa de renda e comercializou para uma faixa de renda superior, foi utilizado um modelo com serviços condominiais que juntamente com a formalização dos serviços públicos - veio acompanhado de um aumento de despesas para os moradores, construções foram feitas com materiais de baixa qualidade, a alocação foi feita desconsiderando os laços com as comunidades de origem e sem acesso a serviços públicos e edifícios foram utilizados para a realocação de despejados pelo governo e pela chuva. Observou-se ainda que áreas rurais foram utilizadas para os empreendimentos, a produção foi concentrada em poucos Municípios no Estado do Pará, em Belém não foi possível a construção para a faixa de zero a três salários mínimos, por vezes se utilizou de mão-de-obra irregular, foi utilizado o modelo de condomínios fechados, alguns imóveis foram ocupadas por famílias que não fazem parte do programa, e, em geral, há uma concentração de empreendimentos para a população de menor renda nas periferias.

Constataram-se algumas ampliações ilegais e vendas de apartamentos, o que pode indicar que: o modelo das unidades pode não estar adequado às necessidades dos 
moradores e as políticas habitacionais despreendidas de políticas de emprego e renda podem ser limitadas para resolver a situação da população mais pobre.

A distribuição dos recursos do PMCMV obedeceu à estimativa do déficit habitacional estimado pela Fundação João Pinheiro, conforme Cardoso et al. (2013, p. 38):

Essa distribuição estabeleceu, na verdade, cotas máximas de acesso a recursos, já que o acesso dependeria da demanda a ser apresentada à Caixa Econômica pelas empresas. Por essa razão, no final de 2010, alguns estados reclamavam junto ao governo por terem já "estourado" a sua meta e não disporem de mais recursos enquanto outros permaneciam aquém da meta original.

Desse modo, segundo estudo de Cardoso et al. (2013), enquanto Alagoas (138,83\%), Goiás (127,14\%), Paraná (104,99\%), Rio Grande do Sul (116,43\%) e Santa Catarina $(112,08 \%)$ ultrapassaram as metas de unidades contratadas, outros Estados não atingiram metade dela: Amapá (14,30\%), Ceará (22,94\%), Distrito Federal (27,77\%), Tocantins (31,75\%), Rondônia (43,33\%), Paraíba (47,06\%), Amazonas $(48,75 \%)$ e Roraima $(49,02 \%)$. Além disso, é possível destacar a distribuição desigual do programa pelos Municípios desses Estados, concentrada em poucos deles.

Ainda sobre a distribuição dos recursos, a Controladoria Geral da União (2010) constatou que as contratações se distanciaram do déficit dos Estados para a população com renda até três salários mínimos. Enquanto Estados como o Maranhão (13,44\%), Acre $(12,44 \%)$ e Mato Grosso (12,72\%) atingiram uma parcela considerável do déficit mensurado, Amapá (0), Amazonas $(0,40 \%)$ e Distrito Federal $(0,10 \%)$ não atingiram $1 \%$.

A centralização das decisões sobre política habitacional pode limitar o surgimento de soluções inovadoras, o que seria um dos benefícios de realizar políticas públicas dentro de uma federação e pode trazer problemas de inadequação das soluções padronizadas à realidade local, como observam pesquisas sobre o programa Minha Casa, Minha Vida (CARDOSO et al., 2011, p. 18): “Ao adotar procedimentos padrão em todo território nacional, a CEF onera soluções inovadoras que poderiam estar sendo administradas pelas prefeituras." Nas diferentes modalidades do PMCMV são estabelecidas especificações mínimas com medidas e materiais.

No entanto, essa padronização pode ser decorrência também da nova estruturação da construção civil com agrupamento de funções na mesma empresa - incorporadora, financiadora, construtora e proprietária -, fusões de corporações do setor com pequenas e médias construtoras locais, abertura de capital na bolsa de valores, alterações no formato e 
na direção das empresas e construção de tipologias habitacionais mais ou menos padronizadas, conforme aponta Shimbo (2010, p. 54):

Nesse sentido, as decisões quanto à localização dos terrenos e às características dos futuros empreendimentos (que impactam sobremaneira no espaço urbano), bem como quanto às estratégias de contratação de mão-de-obra e à composição final do preço de venda das unidades residenciais são pautadas por um conjunto de diretores e executivos de uma mesma organização, cujo objetivo último é a extração do maior lucro possível.

A padronização tem atingido até mesmo as ações e a organização das entidades que participam do programa (RODRIGUES, 2013, p. 82), sendo incentivada em alguns casos para favorecer a agilidade na aprovação dos projetos:

em 2012 vê-se que os programas e suas normativas se tornam cada vez mais regulados e buscam uma padronização na forma de organizar os movimentos e suas ações. Para acessar os recursos, as entidades precisam seguir um roteiro formal, que muitas vezes não traduz o processo político de organização interna, exigindo, inclusive, mudanças de estatutos sociais, valorizando o formal em detrimento da participação coletiva.

\section{PMCMV $x$ SNHIS}

O Sistema Nacional de Habitação de Interesse Social ainda não havia se estabilizado, quando o Programa Minha Casa, Minha Vida foi criado e priorizado pelo governo federal. As mudanças que deveriam incentivar o planejamento, a participação social e a integração dos entes foram abandonadas antes mesmo de se consolidarem e resultarem em políticas mais efetivas ou coordenadas.

No SNHIS, havia a necessidade da constituição de um plano, um conselho e um fundo e depois o pedido de recursos. No PMCMV, a priorização é destinada a entes que modificam o zoneamento, doam terrenos e desoneram a tributação das obras, sem consideração pelo aspecto urbano do empreendimento, ainda que haja previsão legal sobre áreas consolidadas. A lógica do PMCMV incentiva uma atuação pontual, diante do planejamento estruturado que o sistema declarava buscar.

Na análise de Cláudia M. de M. Eloy, Fernanda de C. Costa e Rossella Rossetto (2013, p. 16):

Pôde-se verificar que os grupos de municípios menos populosos e mais pobres, que mais deveriam empregar soluções habitacionais de menor custo, baseadas em insumos e assistência técnica, como inclusive prevê o PlanHab, são 
justamente os municípios onde o MCMV está mais presente. A hipótese sugerida neste momento, em função das demais análises feitas, que revelam a terra como um dos principais insumos do Programa, é que nessas cidades, onde há menor dinâmica do mercado imobiliário e maior oferta de terras, a execução do Programa seja mais eficiente, logo, com maior capacidade de resposta ao desenvolvimento da economia.

Cabe destacar que a mudança na direção da política pública não foi exclusivamente jurídica. As duas leis, a que criou o sistema e a que criou o PMCMV, são perfeitamente válidas, vigentes, eficazes. No entanto, o direcionamento dos recursos, o foco das ações, a produção de normas infralegais passaram a ser voltados ao segundo programa. Desse modo, apesar de não destruir o arcabouço legal constituído, há uma clara mudança de rumos na política habitacional com o esvaziamento paulatino do sistema. Essa mudança do governo federal levou a mudanças dos demais governos, já que passou a incentivar outro tipo de ação e criação legislativa por parte dos entes subnacionais.

É relevante notar que enquanto o PMCMV esvazia o sistema ao qual devia estar vinculado, o Programa Bolsa Família traz algum incentivo à estruturação do seu respectivo sistema (BICHIR, 2011, p. 239):

Além da qualidade do cadastro, o controle das condicionalidades de saúde e educação e, mais recentemente, a própria adesão municipal ao SUAS, fazem parte do IGD $^{89}$, o índice que controla os repasses federais de recursos municipais. Pode-se afirmar que este mecanismo de repasse de recursos é um importantíssimo indutor de convergência das ações municipais voltadas para o PBF, uma vez que o descumprimento das regras pactuadas com o governo federal implica, no limite, o não repasse de recursos adicionais para operação do programa.

No caso do SNHIS, esse tipo de estratégia não foi assumida, esvaziando o sistema de recursos e sentido estruturador, ao mesmo tempo em que não o extinge, prosseguindo com a adesão dos entes e com a criação de conselhos e fundos de forma paralela, conforme abordagem de Danielle C. KLINTOWITZ (2013, p. 13-14):

Uma regressão linear realizada com os dados de contratação da primeira fase do PMCMV indicou que não existe nenhuma correlação entre a adesão dos

${ }^{89}$ “O Índice de Gestão Descentralizada (IGD) é um indicador que mostra a qualidade da gestão descentralizada do Programa Bolsa Família (PBF), além de refletir os compromissos assumidos pelos estados e municípios na sua adesão ao Programa, como a gestão do Cadastro Único e das condicionalidades. O índice varia entre zero e 1. Quanto mais próximo de 1, melhor a avaliação da gestão desses processos. Com base nesse indicador, o MDS repassa recursos a estados e municípios para a realização da gestão do Bolsa Família. Quanto maior o valor do IGD, maior será também o valor dos recursos a serem repassados." Disponível em: <http://www.mds.gov.br/bolsafamilia/gestaodescentralizada/indice-de-gestaodescentralizada-igd>. Acesso em 20.10.2013. 
municípios ao SNHIS, sua regularidade e implementação dos itens exigidos com o número de contratações nos mesmo municípios. [...] Neste cenário, por um lado o Governo Federal retira a capacidade financeira, e consequentemente, decisória e de atuação do SNHIS, em consequência os municípios também se desmobilizam no atendimento às regras do Sistema e direcionam suas energias para a obtenção do maior número possível de unidades habitacionais por meio do PMCMV que reproduz o modus operandis das políticas habitacionais combatidas pelo Movimento de Reforma Urbana. Desta forma decoupling torna-se mais eficiente, pois as novas sistemáticas esvaziam as anteriores sem, contudo, se precisar ter o ônus político de desmontar o Sistema instituído a partir da luta de um importante movimento social. Assim, sem que se desmonte os mitos geradores constituídos pelas novas institucionalidades conquistadas pelos ativistas da reforma urbana, volta-se a praticar políticas urbanas semelhantes às realizadas anteriormente. Este contexto de decoupling fortalece a realização de novas políticas contrárias às instituídas pelo núcleo original do MCidades, pois a permanência das regras originais - como o SNHIS - conserva no imaginário dos ativistas da reforma urbana uma possibilidade de retorno ao caminho gestado originalmente dentro deste ministério.

\section{Conclusão}

O modelo do Sistema Nacional de Habitação de Interesse Social já demonstrava a concentração de poder no governo federal com os atores-chave e o domínio das decisões centralizados. Sua utilização não necessariamente garantiria melhores resultados para a política, mas seu abandono prematuro, antes mesmo de seu funcionamento efetivo, impediu a estruturação de um sistema coordenado de políticas públicas de habitação.

A criação de programas federais - PAC e PMCMV -, ao desconsiderar ou subordinar a estrutura que vinha sendo desenhada para a habitação de interesse social, demonstra o descasamento entre a política econômica e de desenvolvimento e a política de habitação para a população de baixa renda. Tal distanciamento foi possível em razão da concentração de recursos econômicos, administrativos e políticos no governo federal, bem como da subordinação dos entes federados, que buscam atrair investimentos para a execução de políticas públicas em seus territórios, o que pode gerar efeitos positivos para a trajetória política de seus governantes. 
Por concentrar recursos e decisões, a União é capaz de induzir comportamentos dos entes federados. Suas escolhas, porém, têm favorecido ações que normalmente não contam com participação popular, zoneamentos pontuais, doações de terrenos e renúncia fiscal, fazendo com que os entes federados abram mão de suas receitas e de seu patrimônio, em vez de incentivar o planejamento participativo e continuado das ações, promovendo a qualidade e a efetividade dos planos diretores e dos planos locais de habitação de interesse social, e a aplicação dos instrumentos urbanísticos, especialmente os de combate aos imóveis vazios urbanos e à especulação imobiliária.

Há pouca diversidade de políticas públicas sendo produzidas com recursos federais: a concentração de recursos públicos e regulados pela União direcionados à produção e ao financiamento de unidades individuais não incentiva o desenvolvimento da política urbana e de alternativas locais de políticas habitacionais. A escolha por um modelo de política pública prioriza atores e gera consequências diversas em sua efetividade e na construção do espaço: no caso do financiamento para a construção de novos imóveis, priorizou-se a atuação das construtoras e da CEF, independentemente das competências constitucionais estabelecidas para a habitação e dos resultados que podem ser gerados no espaço urbano e na qualidade de vida.

É possível, a partir disso, fazer duas considerações diferentes. Aceitando as condições atuais em que a política se dá, ou seja, os pontos de decisão pertencendo à União e grande parte dos entes federados apresentando fragilidades, é razoável propor que a indução promovida pela União seja mais adequada, perene, planejada e com participação popular. Poderia ser reativada a estrutura já criada do sistema, com a ampliação dos recursos aportados e com o aperfeiçoamento dos instrumentos já instituídos. A destinação de recursos para o desenvolvimento institucional era uma tentativa importante de incentivo à auto-organização e à melhoria da capacidade administrativa, especialmente nos Municípios, a qual poderia ser retomada e aprimorada. Dentro do sistema, é possível ainda incentivar iniciativas locais com a destinação de recursos federais para esse fim, com liberdade de financiamento de modalidades eleitas localmente, induzindo os entes federados a desenhar medidas mais adequadas a suas realidades, vantagem importante das políticas sociais em sistemas federativos. Na reforma do sistema poderia se pensar também em um tratamento mais desigual dos entes federados e no incentivo àqueles que conseguirem progressiva melhora na capacidade administrativa, no planejamento urbano e 
bons resultados nas políticas de habitação, além de priorizar áreas com maiores déficits e com mais pessoas em situação de risco.

A outra perspectiva a ser considerada é a de modificação das estruturas da federação brasileira, criando-se a possibilidade de acesso aos recursos de maneira autônoma pelos entes federados, o que poderia se dar com uma reforma total das instituições federativas, incluindo a redistribuição dos tributos, das responsabilidades e dos recursos, ou com transferências menos condicionadas, que possibilitem maior liberdade nas escolhas de políticas públicas. Repensar o papel das regiões metropolitanas e ampliar o apoio aos Municípios, especialmente por parte dos governos estaduais, também deve estar na agenda da reforma federativa.

A predominância do uso dos recursos onerosos do SBPE e FGTS frente ao baixo gasto orçamentário indica o não enfrentamento do problema de provisão habitacional para a população de mais baixa renda, que concentra o déficit habitacional no país. É necessário refletir sobre o modelo dominante de financiamentos individuais para obtenção da propriedade privada de novas unidades, que não se mostraram efetivos ou suficientes, perpetuando desigualdades e não resolvendo a questão habitacional no país, por vezes agravando-a com o aumento de preços e diminuição do acesso. Deveria ser priorizado o desenvolvimento de maior diversidade de políticas como, por exemplo, a locação social, a utilização de imóveis públicos, o uso da legislação sobre abandono e o emprego mais racional do espaço urbano com o combate à ociosidade especulativa dos imóveis.

A garantia constitucional do direito à moradia e à cidade não assegura sua efetividade e sua progressiva implementação pode se dar de diversos modos. Dessa maneira, o avanço mais recente foi a priorização da questão habitacional; no entanto, a entrada do problema na agenda, com o aumento de recursos destinados a essa finalidade se deu sob uma política bastante limitada e que não se relaciona com o Plano Nacional de Habitação ou com o SNHIS.

A moradia, em sua definição mais ampla, deve incluir o acesso a diversos outros direitos, bem como a política habitacional efetiva deve se relacionar com diversas outras políticas, competências, capacidades, mas essa cooperação ainda se mostra bastante deficiente. A descoordenação da atuação dos entes se verifica em diversos momentos: na política econômica de financiamento do governo federal, que não incentiva o desenvolvimento da política urbana municipal; na falta de articulação dos serviços 
públicos com as entregas de unidades habitacionais; no plano diretor que não se relaciona com os planejamentos setoriais das três esferas de governo.

Em um país tão desigual, pensar em soluções habitacionais homogêneas é contraproducente. É claro que a descoordenação, os problemas e atrasos não são fruto apenas de erros no desenho das políticas, mas são resultados de processos muito mais amplos de apropriação do público pelo privado que precisariam de reformas muito mais radicais para serem amenizados. A ideologia da casa própria, que afeta não apenas os beneficiários das políticas, mas aqueles que as desenham, também é fruto de uma sociedade e de um sistema jurídico que valoriza a propriedade individual, desconsiderando outras formas de obtenção da moradia como a concessão de imóveis públicos, a posse e a locação.

O cenário parece ser de poucos avanços: depois de décadas de críticas ao $\mathrm{BNH}$, seu modelo continua influenciando as políticas públicas de habitação; depois de os Municípios serem declarados entes, continuam tendo que se subordinar às políticas federais em busca de recursos.

Cabe aos movimentos populares, às organizações não governamentais, à burocracia governamental em todas as suas esferas, aos políticos comprometidos com as causas populares, à universidade e à sociedade em geral, que sofre com a baixa qualidade de vida nas cidades, propor e pressionar por políticas habitacionais diversificadas e mais efetivas, que não sejam apenas fonte de lucro e votos para empreendedores privados e governantes, mas que possam produzir moradia digna bem localizada, com a garantia do direito à cidade a todos.

\section{Bibliografia}

ABRUCIO, Fernando Luiz. Descentralização e coordenação federativa no Brasil: lições dos anos FHC. In: Abrucio, Fernando Luiz; Loureiro, Maria Rita Garcia (orgs.). O Estado numa era de reformas: Os anos FHC - Parte 2. Brasília: MP/SEGES, 2002, pp. 143-246.

. A coordenação federativa no Brasil: experiência do período FHC e os desafios do Governo Lula. In Revista Sociologia e Política, Curitiba, 24, p. 41-67, jun. 2005.

Três agendas, seus resultados e um desafio: balanço recente da administração pública federal brasileira In Desigualdade \& Diversidade - Dossiê Especial, segundo semestre de 2011, pp. 119-142. 
; FRANZESE, Cibele; SANO, Hironobu. Coordenação e cooperação no federalismo brasileiro: avanços e desafios. In: CUNHA, Alexandre dos Santos; MEDEIROS, Bernardo Abreu de; AQUINO, Luseni Cordeiro de (Orgs.). Estado, instituições e democracia: República. Brasília: IPEA, 2010. v. 1, p. 177-212.

AFFONSO, Rui de Britto Alvares. O Federalismo e As Teorias Hegemônicas da Economia do Setor Público na Segunda Metade do Século XX: um balanço critico. 2004. Tese de Doutorado. Universidade Estadual de Campinas, Instituto de Economia.

AFONSO, José Roberto Rodrigues. Novos Desafios à Descentralização Fiscal no Brasil: As Políticas Sociais e as de Transferências de Renda, 2006. Disponível em: $<$ http://www.eclac.org/ilpes/noticias/paginas/5/22145/26Jan07-JRAfonso-Brasil.pdf>.

Acesso em 6.dez.2011.

AFONSO DA SILVA, José. Curso de Direito Constitucional Positivo. $24^{\mathrm{a}}$ edição. Malheiros: São Paulo, 2005.

AGUIAR, Marcos Henrique. O Fundo Nacional de Habitação de Interesse Social: avanços e limites na perspectiva da reforma urbana. Dissertação de Mestrado. Pósgraduação em Planejamento Urbano e Regional. Universidade Federal do Rio de Janeiro, 2008 .

ALMEIDA, Fernanda Dias Menezes de. Competências na Constituição de 1988. São Paulo: Atlas, 1991.

ALMEIDA, Fernando Dias Menezes de. Crítica ao tratamento constitucional do Município como ente da Federação brasileira In Revista de Direito Constitucional e Internacional, São Paulo, v. 17, n. 68, p. 76-85, jul/set.2009.

. Comentários aos arts. $4^{\circ}$ a $8^{\circ}$ e 21 a 24. In: MEDAUAR, Odete; ALMEIDA, Fernando Dias Menezes de. (Org.). Estatuto da Cidade: lei 10.257, de 10.07.2011 Comentários. $1^{\text {a }}$ edição. São Paulo: Revista dos Tribunais, 2002.

. Considerações sobre os Municípios no Brasil. In TAVARES, André Ramos; FERREIRA, Olavo A. V. Alves; LENZA, Pedro. Constituição Federal: 15 anos mutação e evolução. São Paulo: Método, 2003, pp.313-319.

. Conflito entre Entes Federativos: Atuação do Supremo Tribunal Federal no regime da Constituição de 1988, pp.217-234. In MORAES, Alexandre de (org.). Os 20 anos da Constituição da República Federativa do Brasil. São Paulo: Atlas, 2008.

ANDRADE, Letícia Queiroz de. Desapropriação de bens (à luz do princípio federativo). São Paulo: Malheiros, 2006.

ANSELMO, José Roberto. O papel do Supremo Tribunal Federal na concretização do federalismo brasileiro. Tese de Doutorado. Faculdde de Direito. São Paulo: Pontifícia Universidade Católica, 2006. 
ANTUNES, Paulo de Bessa. Federalismo e competências ambientais. Lumen Juris: Rio de Janeiro, 2007.

ARANTES, Pedro Fiori. O ajuste urbano: as políticas do banco mundial e do BID para as cidades. In Pós n.20, São Paulo, dezembro 2006. p. 60-75.

ARRETCHE, Marta Teresa da Silva. Desarticulação do BNH e autonomização da política habitacional. In AFFONSO, Rui de Britto Álvares e SILVA, Pedro Luiz Barros (orgs.). Descentralização e políticas sociais. São Paulo: FUNDAP, 1996 (Federalismo no Brasil), p. 107-137.

Política habitacional entre 1986 e 1994. In ARRETCHE, Marta Teresa da Silva e RODRIGUEZ, Vicente (orgs.). Descentralização das políticas sociais no Estado de São Paulo. São Paulo: FUNDAP: Fapesp; Brasília, IPEA, 1998, p. 104-131.

Estado federativo e políticas sociais: determinantes da descentralização. Rio de Janeiro: Revan; São Paulo: FAPESP, 2000.

Federalismo e democracia no Brasil: a visão da ciência política norte-americana. In São Paulo em Perspectiva, n. 15, 2001, pp. 23-31.

. Relações Federativas nas Políticas Sociais. In Educação e sociedade, vol. 23, $\mathrm{n}^{\mathrm{o}}$ 80, 2002a, pp. 25-48.

Federalismo e Relações Intergovernamentais no Brasil: A Reforma de Programas Sociais In DADOS - Revista de Ciências Sociais, Rio de Janeiro, vol. 45, n.3, 2002b, pp. 431-458.

Continuidades e Descontinuidades da Federação Brasileira: De como 1988 facilitou 1995 In DADOS - Revista de Ciências Sociais, Rio de Janeiro, vol. 52, n. 2, 2009, pp. 377-423.

Federalismo e igualdade territorial: uma contradição em termos? In Democracia, federalismo e centralização no Brasil. Rio de Janeiro: Editora FGV; Editora fiocruz, 2012, pp. 173-202.

; RODDEN, Jonathan. Política Distributiva na Federação: Estratégias Eleitorais, Barganhas Legislativas e Coalizões de Governo In DADOS - Revista de Ciências Sociais, Rio de Janeiro, vol. 47, n. 3, 2004, pp. 549-576.

; CORDEIRO, B. S.; Fusaro, Edgard; DIAS, E. C.; BITTAR, M. Capacidades Administrativas dos Municípios Brasileiros para a Política Habitacional. Brasília/São Paulo: Ministério das Cidades/Centro de Estudos da Metrópole, 2012.

; Vazquez, Daniel; Fusaro, Edgard. Capacidades Administrativas, Déficit e Efetividade na Política Habitacional. Brasilia: Ministerio das Cidades, 2007.

AZEVEDO, Sérgio. Desafios da Habitação Popular no Brasil: políticas recentes e tendências. In CARDOSO, Adauto Lucio (coord.) Coleção Habitare - Habitação Social nas Metrópoles Brasileiras - Uma avaliação das políticas habitacionais em Belém, Belo 
Horizonte, Porto Alegre, Recife, Rio de Janeiro e São Paulo no final do século XX. Porto Alegre, 2007, pp. 13-41.

AZEVEDO, Sergio de; ARAUJO, Maria Bernadette. Questões metodológicas sobre o "déficit habitacional": o perigo de abordagens corporativas. In Cadernos metrópole, n. 17 pp. 241-255, 2007.

AZZONI, Carlos R.; CARMO, Heron E. do; MENEZES, Tatiane. Comparações da Paridade do Poder de Compra entre Cidades: Aspectos Metodológicos e Aplicação ao Caso Brasileiro. In Pesquisa e Planejamento Econômico, v.33, n.1, abril de 2003, pp.91-126.

BARROSO, Luís Roberto. O Direito Constitucional e a Efetividade de Suas Normas: Limites e Possibilidades da Constituição Brasileira. 9a edição. Rio de Janeiro: Renovar, 2009.

BASSUL, José Roberto. Estatuto da Cidade: quem ganhou? quem perdeu? Brasília: Senado Federal, Subsecretaria de Edições Técnicas, 2005.

BERCOVICI, Gilberto. Dilemas do Estado Federal Brasileiro. Porto Alegre: Livraria do Advogado, 2004.

Constituição Econômica e desenvolvimento: uma leitura a partir da Constituição de 1988. São Paulo: Malheiros, 2005.

BICHIR, Renata Mirandola. Mecanismos federais de coordenação de políticas sociais e capacidades institucionais locais: o caso do Programa Bolsa Família. Tese de doutoramento. Universidade do Estado do Rio de Janeiro. Instituto de Estudos Sociais e Políticos (IESP). Rio de Janeiro, 2011.

BOLAFFI, Gabriel. Habitação e urbanismo: o problema e o falso problema In MARICATO, Ermínia (org.). A produção capitalista da casa (e da cidade) no Brasil industrial. São Paulo: alfa-omega, 1979, pp.37-70.

BONATES, Mariana Fialho. Ideologia da Casa Própria...Sem Casa Própria: O Programa de Arrendamento Residencial na cidade de João Pessoa-PB. Dissertação de Mestrado. Universidade Federal do Rio Grande do Norte. Pós-graduação em Arquitetura e Urbanismo, 2007.

BONDUKI, Nabil. Origens da Habitação Social no Brasil. In Análise Social, vol. xxix (127), $1994 \quad\left(3 .^{\circ}\right), \quad$ pp. 711-732. Disponível em: $\langle$ http://www.ufpel.edu.br/faurb/prograu/documentos/artigo1-habitacaosocial.pdf $>$. Acesso em: 12.03.2013.

- Política habitacional e inclusão social no Brasil: revisão histórica e novas perspectivas no governo Lula. In Revista Eletrônica de Arquiteturaa e Urbanismo. Universidade São Judas Tadeu: São Paulo, set. 2008. Disponível em < http://www.usjt.br/arq.urb/numero_01/artigo_05_180908.pdf $>$. Acesso em 23.10.2012.

Do Projeto Moradia ao Minha Casa, Minha Vida. In Teoria e Debate, $\mathrm{n}^{\mathrm{o}} 82$, maio/junho 2009. 
Planos locais de habitação: das origens aos dilemas atuais das regiões metropolitanas, p. 29-43 In DENALDI, Rosana. Planejamento habitacional: notas sobre a precariedade e terra nos planos locais de habitação. São Paulo: Annablume, 2013.

. Origens da habitação social no Brasil: arquitetura moderna, lei do inquilinato e difusão da casa própria. São Paulo: Estação Liberdade, 2002.

BOTELHO, Adriano. A cidade como negócio: produção do espaço e acumulação do capital no município de São Paulo In Cadernos Metrópole nº18, pp. 15-38, 2º sem. 2007.

BRASIL. BANCO CENTRAL (BC). Índice de Valores de Garantia de Imóveis Residenciais Financiados (IVG-R), disponível em: $<$ https://www3.bcb.gov.br/sgspub/consultarvalores/consultarValoresSeries.do?method=co nsultarValores>. Acesso em 20.07.2013.

Resumo Mensal do Setor: dezembro de 2005, 2006, 2007, 2008, 2009, 2010, 2011, 2012. Disponível em: 〈http://www.bcb.gov.br/?SFHESTAT>. Acesso em 20.03.2013.

BRASIL. CAIXA ECONÔMICA FEDERAL (CEF). Demanda habitacional no Brasil. Brasília: CAIXA, 2011.

. 2010. Garantindo conquistas: o papel da Caixa Econômica Federal. Disponível em: 〈http://downloads.caixa.gov.br/ arquivos/fgts/relatoriosacoes/Livro40Anos G.pdf> Acesso em 20.03.2013.

BRASIL. Relatório de Gestão do Fundo de Desenvolvimento Social, 2011.

BRASIL. FUNDO DE GARANTIA DO TEMPO DE SERVIÇO (FGTS). Conselho Curador do FGTS. Caixa. Ministério das Cidades. Ministério da Fazenda. Ministério do Trabalho e Emprego. Demonstrações Financeiras do FGTS: Relatório de Administração do FGTS, Exercícios de 2005, 2006, 2007, 2008, 2009, 2010, 2011, 2012. 2006, 2007, 2008, 2009, 2010, 2011, 2012, 2013.

BRASIL. MINISTÉRIO DAS CIDADES (MCIDADES). Secretaria Nacional de Habitação. Déficit habitacional no Brasil 2007. Brasília, 2009a.

BRASIL. MINISTÉRIO DAS CIDADES. Pesquisa Plano Diretor, 2006. Disponível em: <http://www.cidades.gov.br/index.php/planejamento-urbano/368-pesquisa-plano-diretor $>$. Acesso em 20.03.2012.

BRASIL. MINISTÉRIO DAS CIDADES. Situação SNHIS. 2013. Disponível em: $<$ http://www.cidades.gov.br/index.php/sistema-nacional-de-habitacao-de-interesse-socialsnhis $>$. Acesso em 09.07.2013, atualizado até 05.07.2013.

BRASIL. MINISTÉRIO DAS CIDADES (MCIDADES). Política Nacional de Habitação In Cadernos Mcidades Habitação 4, 2004.

BRASIL. MINISTÉRIO DAS CIDADES (MCIDADES). Secretaria Nacional de Habitação. Plano Nacional de Habitação, 2009b. 
BRASIL. MINISTÉRIO DAS CIDADES (MCIDADES. FNHIS). Relatório de Gestão do FNHIS-2009, 2010.

BRASIL. MINISTÉRIO DAS CIDADES. Pesquisa Plano Diretor: terceirização e consultorias. 2006. Disponível em: <http://www.cidades.gov.br/index.php/planejamentourbano/368-pesquisa-plano-diretor $>$. Acesso em 20.12.2012.

BRASIL. MINISTÉRIO DO PLANEJAMENTO, ORÇAMENTO E GESTÃO (MPOG). Instituto Brasileiro de Geografia e Estatística - IBGE. Coordenação de População e Indicadores Sociais. Pesquisa de Informações Básicas Municipais: Perfil dos Municípios Brasileiros: Finanças Públicas 1998-2000. 2004.

BRASIL. TRIBUNAL DE CONTAS DA UNIÃO. Relatório 429, 2011.

BRASIL. MINISTÉRIO DO PLANEJAMENTO, ORÇAMENTO E GESTÃO. Instituto Brasileiro de Geografia e Estatística - IBGE, Diretoria de Pesquisas, Coordenação de População e Indicadores Sociais, Pesquisa de Informações Básicas Municipais, 2011 a.

BRASIL. MINISTÉRIO DO PLANEJAMENTO, ORÇAMENTO E GESTÃO. Instituto Brasileiro de Geografia e Estatística - IBGE, Diretoria de Pesquisas, Coordenação de População e Indicadores Sociais. Pesquisa de Informações Básicas Municipais 2009.

. Pesquisa de Informações Básicas Municipais 2008.

Pesquisa de Informações Básicas Estaduais, 2012.

BRASIL. MINISTÉRIO DO PLANEJAMENTO, ORÇAMENTO E GESTÃO. Instituto Brasileiro de Geografia e Estatística - IBGE. Censo Demográfico 2010. Rio de Janeiro, 2010a.

BRASIL. MINISTÉRIO DO PLANEJAMENTO, ORÇAMENTO E GESTÃO. Instituto Brasileiro de Geografia e Estatística - IBGE. Censo Demográfico 2010: Aglomerados subnormais - Primeiros resultados. Rio de Janeiro, 2010b.

BRASIL. MINISTÉRIO DO PLANEJAMENTO, ORÇAMENTO E GESTÃO. Instituto Brasileiro de Geografia e Estatística - IBGE. Pesquisa Anual da Indústria da Construção, volume 21, 2011b.

BRASIL. Via Pública; Lab hab-Fupam; Logos Engenharia. Plano Nacional de Habitação: Contextualização do Plano Nacional de Habitação. Produto 2, vol. I, 2007.

BRASIL. Via Pública; Lab hab-Fupam; Logos Engenharia. Plano Nacional de Habitação: Produto 3, 2008.

BRASIL. PRESIDÊNCIA DA REPÚBLICA. CONTROLADORIA-GERAL DA UNIÃO (CGU. FNHIS). Secretaria Federal de Controle Interno. Relatório de Auditoria Anual de Contas. Unidade auditada: Fundo Nacional de Habitação de Interesse Social, Exercício de 2007. 2008. 
BRASIL. PRESIDÊNCIA DA REPÚBLICA. CONTROLADORIA-GERAL DA UNIÃO (CGU. SNH). Secretaria Federal de Controle Interno. Relatório de Auditoria Anual de Contas. Unidade auditada: Secretaria Nacional de Habitação, Exercício de 2008. 2009.

BRASIL. PRESIDÊNCIA DA REPÚBLICA. CONTROLADORIA-GERAL DA UNIÃO (CGU). Secretaria Federal de Controle Interno. Relatório de Auditoria Anual de Contas. Exercício de 2009. 2010.

BRASIL. PRESIDÊNCIA DA REPÚBLICA. CONTROLADORIA-GERAL DA UNIÃO (CGU. SNH). Secretaria Federal de Controle Interno. Relatório de Auditoria Anual de Contas. Unidade auditada: Secretaria Nacional de Habitação, Exercício de 2010. 2011.

BRASIL. PRESIDÊNCIA DA REPÚBLICA. CONTROLADORIA-GERAL DA UNIÃO (CGU. CEF). Secretaria Federal de Controle Interno. Relatório de Auditoria Anual de Contas. Unidade auditada: Caixa Econômica Federal - Programas Sociais, Exercício de 2008. 2009.

BRASIL. TRIBUNAL DE CONTAS DA UNIÃO (TCU). Relatório e parecer prévio sobre as contas do governo da República. Brasília: TCU, 2006, 2007, 2008, 2009, 2010, 2011, 2012 e 2013. Anos de referência 2005, 2006, 2007, 2008, 2009, 2010, 2011 e 2012.

BRASIL. MINISTÉRIO DO TRABALHO E EMPREGO (MTE). Conselho Curador do Fundo de Garantia do Tempo de Serviço (CCFGTS). Relatório de Gestão do Fundo de Garantia do Tempo de Serviço. Exercícios de: 2008, 2009, 2010, 2011 e 2012. 2009, 2010, 2011, 2013.

BRASIL. MINISTÉRIO DAS CIDADES. CAIXA ECONÔMICA FEDERAL. Relatório de Gestão do Fundo de Arrendamento Residencial, 2010 e 2013.

BRASIL. Secretaria de Assuntos Estratégicos da Presidência da República. Instituto de Pesquisa Econômica Aplicada (IPEA). GOMES, Gustavo Maia; MAC DOWELL, Maria Cristina. Texto para discussão $n^{\circ} 706$. Descentralização Política, Federalismo Fiscal e Criação de Municípios: o que é mau para o econômico nem sempre é bom para o social. Brasília, 2000.

BRASIL. Secretaria de Assuntos Estratégicos da Presidência da República. Instituto de Pesquisa Econômica Aplicada (IPEA). Comunicado do IPEA $n^{\circ}$ 122: Governo gastador ou transferidor? - um macrodiagnóstico das despesas federais (2001-2011), 2011a.

BRASIL. Secretaria de Assuntos Estratégicos da Presidência da República. Instituto de Pesquisa Econômica Aplicada (IPEA). Comunicado $n^{\circ} 118$. O planejamento da habitação de interesse social no Brasil: desafios e perspectivas, $2011 \mathrm{~b}$.

BRASIL. Secretaria de Assuntos Estratégicos da Presidência da República. Instituto de Pesquisa Econômica Aplicada (IPEA). Comunicados do IPEA $n^{\circ}$ 146. O programa Minha Casa Minha Vida em municípios de até 50 mil habitantes: Quadro institucional e prognósticos da provisão habitacional de interesse social, 2012. 
BRASIL. Secretaria de Assuntos Estratégicos da Presidência da República. Instituto de Pesquisa Econômica Aplicada (IPEA). Texto para discussão $n^{\circ} 1853$. Minha Casa, Minha Vida, Nosso Crescimento: onde fica a política habitacional. 2013.

BUCCI, Maria Paula Dallari. O conceito de políticas publicas em Direito In BUCCI, Maria Paula Dallari (org.) Políticas Públicas: reflexões sobre o conceito jurídico. São Paulo: Saraiva, 2006. pp 1-49.

BUONFIGLIO, Leda Velloso; BASTOS, Rodrigo Dantas. O lugar das políticas de habitação popular nas cidades brasileiras. In XII Simpurb: Simpósio Nacinal de Geografia Urbana, Belo Horizonte, 2011.

BURNETT, Frederico Lago. As Cidades Brasileiras e a Desigualdade Socioespacial In Revista em pauta, vol. 6, n. 24, dezembro de 2009, pp. 99-112.

BUZAID, Alfredo. O estado federal brasileiro. Brasília: Ministério da Justiça, 1971.

CÂMARA BRASILEIRA DA INDÚSTRIA DA CONSTRUÇÃO. Institucional. Disponível em: 〈http://www.cbic.org.br/institucional >. Acesso em: 20.07.2013.

CARDOSO, Adauto Lucio. Política habitacional no Brasil: balanço e perspectivas. 2008. Disponível em: $<$ http://web.observatoriodasmetropoles.net/index.php?option=com content \&view=article \&id=155:politica-habitacional-no-brasil-balanco-e-perspectivas\&catid=36:colecaotextos\&Itemid=82> . Acesso em: 20.10.2012.

. Desigualdades urbanas e políticas habitacionais. 2009. Disponível em: <http://www.observatoriodasmetropoles.ufrj.br/download/adauto desig urb polhab.pdf>. Acesso em 30.03.2012.

; ARAGÃO, Thêmis Amorim; Araujo, Flávia de Sousa. XIV Encontro Nacional da ANPUR. Rio de Janeiro, 2011. Habitação de interesse social: política ou Mercado? Reflexos sobre a construção do espaço metropolitano.

(org.). O Programa Minha Casa, Minha Vida e seus efeitos territoriais. Rio de Janeiro: Letra Capital, 2013. (Habitação e Cidade).

CARVAlHO, José Murilo de. Pontos e Bordados: escritos de história e política. Belo Horizonte: UFMG, 1998.

Federalismo y Centralización en el Imperio Brasileño, In CARMAGNANI, M. (coord) Federalismos Latinoamericanos: México, Brasil, Argentina. Ciudad de México: El Colegio de México, 1993, pp. 51-80.

CARVALHO, Gilson. A inconstitucional administração pós-constitucional do SUS através de normas operacionais In Ciência \& Saúde Coletiva, vol.6, n.2. São Paulo, 2001, pp. 435-444.

DALLARI, Dalmo de Abreu. O estado federal. São Paulo: Àtica, 1990. 
DI SARNO, Daniela Campos Libório. O princípio da igualdade e o direito urbanístico. In Marrara, Thiago (org.). Princípios de Direito Administrativo. São Paulo: Atlas, 2012.

DIAS, Edney Cielici. Do Plano Real ao Programa Miha Casa, Minha Vida: negócios, votos e as reformas da habitação, 2012. Dissertação (Mestrado em Ciência Política) Faculdade de Filosofia, Letras e Ciências Humanas, Universidade de São Paulo, São Paulo, 2012.

DI PIETRO, Maria Sylvia Zanella. Direito Administrativo. São Paulo: Atlas, 2009.

Função social da propriedade pública, pp.561-572 In WAGNER JUNIOR, Luiz Guilherme da Costa. Direito Público: Estudos em homenagem ao professor Adilson Abreu Dallari. Belo Horizonte, 2004.

ELOY, Claudia Maria de Magalhães; COSTA, Fernanda de Cassia; ROSSETTO, Rossella. Subsídios na política habitacional brasileira: do BNH ao PMCMV. In XV Enanpur, Recife, 2013.

ENGELS, Friedrich. Para a Questão da Habitação. Disponível em: <http://www.marxists.org/portugues/marx/1873/habita/index.htm>. Acesso em 2013-0120. 1982.

ELAZAR, Daniel J. Exploring federalism. University of Alabama: Tuscaloosa, 1991.

ESTADO DE SÃO PAULO. Seade. CDHU. Necessidades Habitacionais no Estado de São Paulo: Subsídios para o Plano Estadual de Habitação 2010-2023. São Paulo: Seade; CDHU, 2010.

ERK, Jan. Does Federalism Really Matter? In Comparative Politics, vol. 39, n. 1, October, 2006, pp. 103-120.

FARIA, José Ricardo Vargas de. Função Social e IPTU progressivo: o avesso do avesso num desenho lógico. In XV Encontro Nacional da Associação Nacional de Planejamento Urbano e Regional, Recife, 2013.

FERNANDES, Nelson da Nóbrega; OLIVEIRA, Alfredo César Tavares de. Marechal Hermes e as (des)conhecidas origens da habitação social no Brasil: o paradoxo da vitrine não-vista. In Scripta Nova: Revista Electrónica de Geografia y Ciencias Sociales, vol. XIV, núm. 331 (87), 1 de agosto de 2010. Disponível em: <http://www.ub.edu/geocrit/sn/sn-331/sn-331-87.htm>. Acesso em 6fev.2013.

FEDERAÇÃO DAS INDÚSTRIAS DO RIO DE JANEIRO. Índice FIRJAN de Desenvolvimento Municipal. Disponível em: 〈http://www.firjan.org.br/ifdm/>. Acesso em: 20.07.2012.

FIGUEIREDO, Glória Cecília; BALTRUSIS, Nelson; OLIVEIRA, Elizabeth. Política Nacional de Habitação hoje: Produção de mercado com recursos do SBPE como ação dominante. In Arquitextos, ano 14, out.2013. Disponível em: $\langle$ http://www.vitruvius.com.br/revistas/read/arquitextos/14.161/4905>. Acesso em 15.12.2013. 
FIX, Mariana de Azevedo Barretto. Financeirização e Transformações Recentes no Circuito Imobiliário no Brasil. Tese (Doutorado em Desenvolvimento Econômico). Instituto de Economia, Universidade Estadual de Campinas, Campinas, 2011.

FOLHA DE SÃO PAUlO. Caderno: Poder. Edição de 27 de novembro de 2010. Disponível em: <http://www1.folha.uol.com.br/fsp/poder/po2711201020.htm>. Acesso em 20.08.2013.

GARMAN, Christopher; HAGGARD, Stephan; WILLIS, Eliza. Fiscal Decentralization: A Political Theory with Latin American Cases. In World Politics, vol. 53, n. 2, Jan, 2001, p. 205-236.

GONÇALVES, Renata da Rocha; LOTTA, Gabriela Spanghero; BITELMAN, Marina Farkas. A Coordenação Federativa de Políticas Públicas Duas Décadas Após a Constituição Federal de 1988. In Encontro de Administração Pública e Governança. Salvador, 2008.

HARVEY, David. O trabalho, o capital e o conflito de classes em torno do ambiente construído nas sociedades capitalistas avançadas In Espaço e debates, n. 6, set/out/82, pp. 6-35.

JORGE, Wilson Edson. A Política Nacional de Saneamento pós-64. Tese de Doutorado. São Paulo: Universidade de São Paulo, Faculdade de Arquitetura e Urbanismo, 1988.

KLINTOWITZ, Danielle Cavalcanti. O Movimento Nacional de Reforma Urbana e a construção de uma nacional política de desenvolvimento urbano pós-redemocratização: da cooptação à estruturação de um funcionamento de decoupling. In XV ENANPUR. Recife, 2013.

LAGO, Luciana Corrêa. Autogestão da moradia na superação da periferia urbana: conflitos e avanços In E-metropolis, n. 05, ano 2, junho de 2011.

LANNOY, Camilo Pablo de. O descompasso das políticas públicas para a solução do déficit habitacional. Dissertação de mestrado. Universidade de Brasília, 2006.

LEVIN, Alexandre. Parcelamento, edificação e utilização compulsórios de imóveis públicos urbanos. Belo Horizonte: Fórum, 2010.

LOTTA, Gabriela Spanghero; VAZ, José Carlos. A contribuição dos arranjos institucionais complexos para a efetividade das políticas públicas no Brasil. In XVII Congreso Internacional del CLAD sobre la Reforma del Estado y de la Administración Pública, Cartagena, Colombia, 30 oct. - 2 Nov. 2012. Disponível em: <http://www.dgsc.go.cr/dgsc/documentos/cladxvii/lottagab.pdf $>$ Acesso em 12.03.2013.

MELLO, Oswaldo Aranha Bandeira de. Natureza Jurídica do Estado Federal. São Paulo: Prefeitura de São Paulo, 1948.

MENDES, Marcos. Federalismo Fiscal In BIDERMAN, Ciro; ARVATE, Paulo (orgs.). Economia do Setor Público no Brasil. Rio de Janeiro: Elsevier, 2005. 
MARICATO, Ermínia. O impasse da política urbana no Brasil. Petrópolis: Vozes, 2011.

. Brasil, cidades: alternativas para a crise urbana. Petrópolis, Vozes, 2001.

; SANTOS JUNIOR, Orlando Alves dos. Construindo a Política Urbana: participação democrática e o direito à cidade, 2006. Disponível em: < http://gestaocompartilhada.pbh.gov.br/sites/gestaocompartilhada.pbh.gov.br/files/bibliotec a/arquivos/partic_democratica_e_direito_a_cidade.pdf > Acesso em jan.2013.

MIRANDA. Alcides Silva de. Análise estratégica dos arranjos decisórios na comissão intergestores tripartite do sistema único de saúde. Tese de Doutorado. Instituto de Saúde Coletiva. Salvador: Universidade Federal da Bahia, 2003.

MELO, Marcus André B. C. de. Política de Habitação e Populismo: O caso da Fundação da Casa Popular In Revista RUA: Revista de Arquitetura e Urbanismo. Vol. 3, n. 4/5, 1990. Disponível em: 〈http://www.portalseer.ufba.br/index.php/rua/search/titles?searchPage=5 > Acesso em 20.10.2012.

MENEZES, Tatiane; AZZONI, Carlos R.; MOREIRA, Guilherme R. C. Diferenças em gastos com aluguel entre estados, tipos de area e níveis de renda familiar no Brasil. In BRASIL. IPEA. Gasto e consumo das famílias brasileiras contemporâneas, vol. 2. Brasília, 2007. Disponível em:

〈http://www.ipea.gov.br/agencia/images/stories/PDFs/livros/16 Cap09.pdf > Acesso em 20.09.2012.

NAJAR, Alberto Lopes; MARQUES, Eduardo César. A sociologia urbana, os modelos de análise da metrópole e a saúde coletiva: uma contribuição para o caso brasileiro. In Ciencia e saúde coletiva, vol. 8, n. 3 São Paulo, 2003.

NACIONES UNIDAS. Informe de la Relatora Especial sobre una vivienda adecuada como elemento integrante del derecho a un nivel de vida adecuado. 2012. Disponível em: $<$ http://daccess-ddsny.un.org/doc/UNDOC/GEN/N12/459/21/PDF/N1245921.pdf?OpenElement>. Acesso em 20.07.2013.

NADALIN, Vanessa Gapriotti; BALBIM, Renato. Padrões espaciais da vacância residencial brasileira. In Anais do I Circuito de Debates Acadêmicos: Code 2011.

OBINGER, Hebert; LEIBFRIED, Stephan; CASTLES, Francis G. Federalism and welfare state: new world and European experiences. New York: Cambridge University Press, 2005 .

UNITED NATIONS (UN). Office of the high comissioner for human rights. The right to adequate housing (art. 11(1)): 13/12/1991. CESCR General comment 4. (General Comments). The right to adequate housing. Disponível em: 〈http://www.unhchr.ch/tbs/doc.nsf/(Symbol)/469f4d91a9378221c12563ed0053547e?Open document> Acesso em 17.04.2013. 
PEQUENO, Renato; FREITAS, Clarissa. Programa Minha Casa Minha Vida em Fortaleza: Primeiros Resultados, pp. 115-142 In Cardoso, Adauto Lucio (org.). O Programa Minha Casa, Minha Vida e seus efeitos territoriais. Rio de Janeiro: Letra Capital, 2013.

PEREIRA, Paulo Cesar Xavier. Espaço técnica e construção. São Paulo: Nobel, 1988.

PIERSON, Paul. Fragmented Welfare States: Federal Institutions and the Development of Social policy, In Governance: An International Journal of policy and Administration, vol. 8, n. 4, October 1995, pp.449-478.

PRUD HOMME, Remy. The dangers of decentralization In The World Bank Research Observer, vol. 10, n. 2 August, 1995.

PROUDHON, Pierre-Joseph. Do princípio federativo. São Paulo: Nu-Sol, Imaginário, 2001.

QUADROS, Waldemir; CAVALCANTI, Carlos Eduardo. Partilha de recursos na federação brasileira. Sérgio Prado (coord.), São Paulo: Fapesp: fundap; Brasília: Ipea, 2003. (Federalismo no Brasil).

RIKER, William. Six Books in Search of a Subject or Does Federalism Exist and Does It Matter? In Comparative politics, vol. 2, n. 1, October, 1969, pp. 135-146.

RODDEN, Jonathan. Comparative Federalism and Decentralization: On Meaning and Measurement In Comparative Politics, vol. 36, n. 4, July, 2004, pp. 481-500.

RODRIGUES, Evaniza Lopes. A estratégia fundiária dos movimentos populares na produção autogestionaria da moradia. Dissertação de Mestrado. São Paulo: 2013. Universidade de São Paulo. Faculdade de Arquitetura e Urbanismo.

ROYER, Luciana. Política Habitacional no Estado de São Paulo: Estudo sobre a Companhia de Desenvolvimento Habitacional e Urbano do Estado de São Paulo. Dissertação de Mestrado. Universidade de São Paulo. Faculdade de Arquitetura e Urbanismo. São Paulo, 2002.

Financeirização da Política Habitacional: limites e perspectivas. Tese (Doutorado em Arquitetura e Urbanismo). Faculdade de Arquitetura e Urbanismo, Universidade de São Paulo, São Paulo, 2009.

. Habitação como uma questão metropolitana. In XV Enanpur, Recife, 2013.

ROLNIK, Raquel. A construção de uma política fundiária e de planejamento urbano para o país: avanços e desafios. In Políticas Sociais - Acompanhamento e Análise, 12, fev. 2006, IPEA, pp.199-210.

Impacto da aplicação de novos instrumentos urbanísticos em cidades do Estado de São Paulo. In Revista Brasileira de Estudos Urbanos e Regionais nº 2, nov. 1999.

; NAKANO, Kazuo. As armadilhas do pacote habitacional. Disponível em: <http://www.diplomatique.org.br/artigo.php?id=461 >. Acesso em 25.08.2013. 
SALLUM Jr., Brasilio. Federação, autoritarismo e democratização In Tempo Social Revista de Sociologia da USP, São Paulo, n. 8, pp. 27-52, out. 1996.

SANTOS JUNIOR, Orlando Alves dos; NASCIMENTO, Carla; FERREIRA, Regina Fátima C. F. O Sistema Nacional de Desenvolvimento Urbano: avanços e limites para a descentralização dos canais de participação. s/d.

SAULE JUNIOR, Nelson. O direito a moradia como responsabilidade do estado brasileiro. In Cadernos de Pesquisa do CEBRAP, n. 7, maio/97.

. Bases jurídicas para a instituição de uma lei federal sobre o sistema nacional de desenvolvimento urbano In SAULE JUNIOR, Nelson (org.). Direito urbanístico: vias jurídicas das políticas urbanas, pp. 83-148.

SCAFF, Fernando Facury. Direitos Humanos e a Desvinculação das Receitas da União DRU In Revista de Direito Administrativo, abr-jun/2004, n. 234 pp-33-50.

SERRA, Geraldo. Urbanização e centralismo autoritário. São Paulo: Nobel, Editora da Universidade de São Paulo, 1991.

SHIMBO, Lúcia. Habitação Social, Habitação de Mercado: a confluência entre estados, empresas construtoras e capital financeiro. Tese de doutorado. Pós-graduação em Arquitetura e Urbanismo. Escola de Engenharia de São Carlos. Universidade de São Paulo, 2010.

SIGABRASIL. Disponível em: <http://www12.senado.gov.br/orcamento/sigabrasil > Acesso em 20.05.2013.

SILVA, Jorge Kleber Teixeira; LIMA, Maria Helena Palmer. Evolução do marco legal da criação de municípios no Brasil. Disponível em: < ftp://geoftp.ibge.gov.br/organizacao territorial/divisao territorial/evolucao_da divisao ter ritorial_do_brasil_1872_2010/evolucao_do_marco_legal_da_criacao_de_municipios_no_b rasil.pdf>. Acesso em 12.03.2013.

SOUZA, Celina. Federalismo, Desenho Constitucional e Instituições Federativas no Brasil pós-1988. In Revista de Sociologia e Política, Curitiba, 24, p. 105-121, jun. 2005.

. Redemocratização, Federalismo e Gasto Social no Brasil: tendências recentes. XXIV Encontro Anual da Associação Nacional de Pós-Graduação em Ciências Sociais (ANPOCS). GT03: Estrutura social e desigualdade, 1999. Disponível em: <http://info.worldbank.org/etools/docs/library/232522/SouzaRedemocratizacao.pdf. Acesso em 30.03.2012.

- Governos locais e gestão de políticas sociais universais, In São Paulo em Perspectiva, São Paulo, n.18, v. 2, 2004, pp.27-41.

SOUZA, Celina; CARVALHO, Inaiá M.M. Reforma do estado, descentralização e desigualdades. In Lua nova, n. 48, 1999, pp.187-212.

SOUZA, Marcelo Lopes. $O A B C$ do desenvolvimento urbano, $2^{\mathrm{a}}$ edição. Rio de Janeiro: Bertrand Brasil, 2005. 
SINDUSCON-SP. Déficit Habitacional 2009. 2010. Disponível em: <http://www.sindusconsp.com.br/downloads/economia/estudossetoriais/deficit2009.pdf > Acesso em 20.05.2013.

SINDUSCON-SP. História. 2012. Disponível em: $\langle$ http://www.sindusconsp.com.br/msg2.asp?id=4506 $>$ Acesso em 23.05.2013.

TATAGIBA, Luciana. Os Conselhos Gestores e a Democratização das Políticas Públicas no Brasil In DAGNINO, Evelina. Sociedade Civil e Espaços Públicos no Brasil. São Paulo: Paz e Terra, 2002. p 47-103.

TAYLOR, Brian D. Force and Federalism: Controlling Coercion in Federal Hybrid Regimes In Comparative Politics, vol. 39, n. 4, July, 2007, pp. 421-440.

UN-HABITAT. United Nations Human Settlements Programme. The Habitat Agenda. Disponível em <http://ww2.unhabitat.org/declarations/ch-4b-1.htm>. Acesso em 23.mar.2011.

VILLAÇA, Flávio. O que todo cidadão precisa saber sobre habitação. S.d. Disponível em: 〈http://www.flaviovillaca.arq.br/pdf/cidadao_habita.pdf $>$. Acesso em 30.09.2011.

VALENÇA, Marcio M.; BONATES, Mariana Fialho, The trajectory of social housing policy in Brazil: From the National Housing Bank to the Ministry of the Cities, In Habitat International, 2009.

VOLIA, Angélica A. Tanus Benatti Alvim; KATO, Regina Costa; CASTRO, Luiz Guilherme Rivera de; ZIONI, Silvana Maria. Desafios das Políticas Urbanas no Brasil: a importância dos instrumentos de avaliação e controle social In Cadernos de PósGraduação em Arquitetura e Urbanismo, vol. 6, n. 1, 2006.

WORLD BANK. World Development Report 1997 - the state in a changing world, New York: Oxford University, volume 1.

ZIMMERMANN, Augusto. Teoria Geral do Federalismo Democrático. Rio de Janeiro: Lumen Juris, $2^{\mathrm{a}}$ edição, 2005. 